Dissertação de Mestrado apresentada à Faculdade de Filosofia, Letras e Ciências Humanas da Universidade de São Paulo. Departamento de História. Área de História Social.

\title{
O sentido de História para Alexandre Herculano: uma interpretação romântica (1830 - 1853).
}

Leonardo de Atayde Pereira

Orientador: Prof. Dr. Lincoln Ferreira Secco 
A meus pais, Atayde e Aparecida, pelas constantes lições de amor ... 
Dissertação de Mestrado apresentada à Faculdade de Filosofia, Letras e Ciências Humanas da Universidade de São Paulo. Departamento de História. Área de História Social.

\section{O sentido de História para Alexandre Herculano: uma interpretação romântica (1830 - 1853).}

Leonardo de Atayde Pereira

Orientador: Prof. Dr. Lincoln Ferreira Secco 


\section{Agradecimentos}

Ao orientador deste trabalho, Prof. Dr. Lincoln Ferreira Secco, não apenas pela acolhida do tema desenvolvido, mas, sobretudo, por seus ensinamentos, orientações, confiança e amizade que vem me presenteando desde minha formação inicial como historiador.

As minhas queridas irmãs, Lisandra, sempre presente em meu coração, e Lívia, por seu carinho e afeto.

A minha doce e amada Marília, por sua companhia e compreensão.

Aos meus familiares, em especial minhas avós, Rosa e Sebastiana, e minha Tia Célia, pelas correções e sugestões.

Aos amigos, Dona Sueli, Dona Eugênia, André, Leandro, Everton, Alexandre, Rogério, Renato, Daniel, Luís Henrique, Wagner, Aílton, Gabriel, Felipe, Clayton e Tomy, companheiros que de alguma forma contribuíram para a realização de minha dissertação.

A Secretaria da Educação por ser minha agência financiadora através do programa "Bolsa Mestrado". 


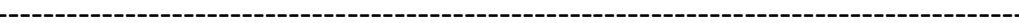

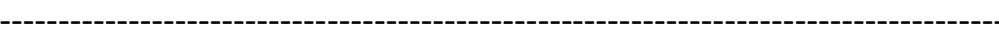

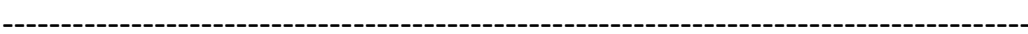


"Imaginar é sonhar, dorme e repousa a vida no entretanto; sentir é viver ativamente, cansa-a e consome-a".

(Almeida Garrett, Viagens na Minha Terra)

"Quando o céu é um deserto para a esperança, onde a acharei na terra? Que pode hoje embriagar-me, senão uma festa de sangue?"

(Alexandre Herculano, Eurico, O Presbitero) 

Resumo:

Alexandre Herculano é considerado um dos introdutores e um dos maiores expoentes do Romantismo em Portugal. Sua obra, fragmentada por produções jornalísticas, literárias e historiográficas, e demonstrando uma grande unidade, soube aliar uma ampla tradição de investigação sobre os problemas políticos, sociais e culturais de seu país. Seu trabalho é ainda pontuado por uma nascente reflexão romântica e liberal sobre o conhecimento histórico. Um dos maiores exemplos de sua literatura e da unidade temática representada pela sua obra é o romance histórico Eurico, O Presbítero, analisado no presente trabalho.

Abstract:

Alexandre Herculano is considered one of the introducers and one of the best illustrions representatives of Romanticism in Portugal. His work, fragmented by jornalistic, literary and historiographic productions, demonstrates a great unit, able to join a large investigation tradition about political, social and cultural problems from his country. Moreover, his work has one increasing romantic and liberal reflection about the historic knowledgement. One of major illustrions examples of his literature which represents the unit theme is the historic novel Eurico, O Presbitero (Eurico, the Priest), analysed on the present work. 
Índice:

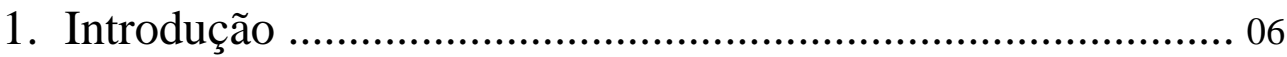

2. Romantismo - o palco das idéias.

2.1. Ilustração e Romantismo - aspectos gerais .........................................07

2.2. Ilustração portuguesa - a idéia de "decadência" cultural......................18

2.3. A experiência liberal - o contexto político de Herculano......................31

2.4. Almeida Garrett e Alexandre Herculano - românticos e liberais...........49

2.4.1. Almeida Garrett: ilustração e romantismo......................................................50

2.4.2. Alexandre Herculano: sua formação e suas interpretações românticas........64

3. O sentido de História para Alexandre Herculano.

3.1. O gênio, "o espírito do povo" e o herói: a contribuição alemã...............87

3.2. A Filosofia da História de Hegel..........................................................99

3.3. A concepção de História de Alexandre Herculano: temas e idéias........104

3.4. O sentido de História nos romances de Herculano..................................121

3.4.1. Diálogos entre História e Literatura..................................................................122

3.4.2. Eurico, O Presbítero - A História e o "fogo das paixões"..............................134

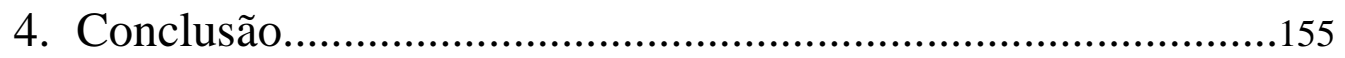

5. Fontes e Bibliografia.

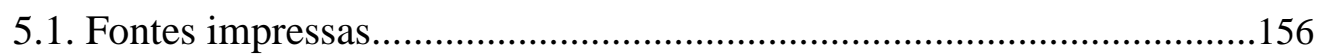

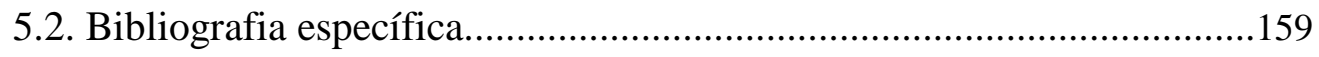

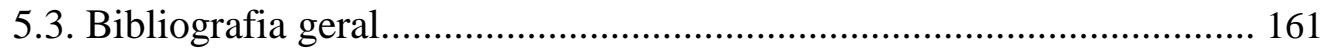




\section{Introdução:}

O propósito deste trabalho é analisar o sentido de História para Alexandre Herculano na tentativa de captar a presença de uma linha filosófica e teórica no seu pensamento historiográfico.

Para isso pretendo resgatar um dos principais focos difusores de idéias do século XIX, o movimento romântico, que definiu uma série de atitudes e temas literários/filosóficos usados, indiscriminadamente, por toda uma geração de artistas, escritores, políticos, filósofos e revolucionários ${ }^{1}$.

Certo da importância e da amplidão de possibilidades que o Romantismo oferece para a estruturação paradigmática do pensamento europeu do século XIX, e da inserção de Alexandre Herculano, ao lado de Almeida Garrett, no início do movimento em Portugal, tomei como necessário mapear as principais vertentes românticas captadas pela primeira geração romântica portuguesa, principalmente, a alemã.

Ao lado das idéias românticas que contribuíram para uma teorização histórica da formação das nacionalidades, temos os efeitos causados pelo advento do modelo político/econômico do liberalismo e pelo eco político e cultural causado pelas revoluções francesa e industrial.

Para uma maior compreensão do pensamento romântico de Alexandre Herculano, nas suas bases sociais e políticas, visualizei como necessário estabelecer uma breve relação com algumas idéias de Garrett e com o contexto político liberal vivido por Portugal no início do século XIX. Foi pensando justamente nesse ambiente político liberal europeu, que entrou em rumo decisivo na Revolução Francesa de 1830, e que guiará o novo momento do liberalismo português, herdeiro da experiência vintista, durante todo o oitocentos, que estabeleci o início de meu recorte temporal.

\footnotetext{
${ }^{1}$ Num importante ensaio de Isaiah Berlin sobre o tema, o autor destaca a radical mudança que o pensamento romântico provocou nos julgamentos referentes às formas de conhecimento até então defendidos, em relação à "reviravolta romântica” afirma que: “(...) nada tão revolucionário ocorreu depois - teve lugar próximo ao final do século XVIII, principalmente na Alemanha; e embora seja bem conhecido sob o nome de "romantismo", seu significado e importância plenos não foram apreciados até agora. (...). O movimento que chamamos romantismo transformou a ética e a política moderna de uma maneira muito mais séria do que nós compreendemos". BERLIN, Isaiah. "A reviravolta romântica: uma crise na história do pensamento moderno". In: O sentido de realidade (estudos das idéias e de sua história). Rio de Janeiro: Editora Civilização Brasileira, 1999, p. 237.
} 
Pensando na importância das idéias alemãs para a estruturação do movimento romântico como um todo e da presença dum possível historicismo romântico no pensamento historiográfico de Herculano, tentarei desvendar algumas linhas básicas da Filosofia da História de Herder e de Hegel.

Tendo como inspiração a ampla possibilidade da historiografia atual de trabalhar com um grande cabedal de fontes, arsenal propício a novos rumos interpretativos da escrita da História, tomei como documentos de análise algumas obras de natureza literária, em destaque para o romance histórico Eurico, O Presbítero, de Alexandre Herculano, na tentativa de buscar a presença de um sentido de História nessas produções e de realizar um diálogo com escritos historiográficos do autor estudado, como nas Cartas sobre a História de Portugal e na História de Portugal, que teve seu último volume publicado em 1853, data limite da periodização estabelecida.

2. O Romantismo - o palco das idéias:

O objetivo desse capítulo é traçar uma breve análise interpretativa da gênese do movimento romântico na Europa com base nas heranças e rupturas com o pensamento ilustrado e no advento das estruturas do capitalismo industrial, elementos norteadores para a fundamentação dos principais aspectos da estética e da crítica romântica. Após esse primeiro contato com alguns elementos constituintes do Romantismo, pretendo apresentar o mesmo movimento histórico da crítica romântica em Portugal, com a permanência de aspectos do pensamento ilustrado português nos julgamentos culturais dos primeiros grandes autores do Romantismo português, Almeida Garrett e Alexandre Herculano.

Com isso, iniciarei um apanhado geral das principais características do Romantismo português sob a ótica das idéias de Garrett e Herculano, suas visões de mundo e preocupações artísticas. Finalmente o capítulo se encerrará com uma breve apresentação do contexto político proposto pelo recorte histórico e das principais idéias referentes à organização social e política portuguesa defendidas por Herculano.

\subsection{Ilustração e Romantismo - aspectos gerais:}


Tanto a origem do Romantismo quanto suas características estéticas são difíceis de determinar devido à grande profusão de inquietações advindas de contextos sociais e culturais diferentes, mostrando o quanto este é heterogêneo e variado ${ }^{2}$, que vão lentamente se influenciando conforme o movimento vai ganhando mais nitidez, constituindo uma unidade de temas.

O Romantismo, visto como visão de mundo representa uma nítida e gradual mudança na sensibilidade européia, que começa com mudanças paradigmáticas do pensamento ilustrado e se intensifica com a gestão de uma nova ordem social e econômica, guiada por importantes mudanças na esfera política, como o surgimento de governos anti-absolutistas e liberais ${ }^{3}$, e por emblemáticas reviravoltas na produção industrial, que passa a ser intensificada em muitos países, alterando, desta maneira, a relação entre produção e consumo, e o modo como a sociedade, como um todo, encara a realidade.

Antes de detalhar os significados do Romantismo, torna-se necessária uma rápida incursão nas origens da palavra ${ }^{4}$ que nomeia esse movimento. Aparentemente, os adjetivos que se ligam à palavra "aparecem muito antes do verdadeiro advento do fenômeno", , e eram utilizados, mais ou menos desde o século XVIII, para qualificar toda a produção cultural que tivesse as características dos "romances" medievais, estas

\footnotetext{
2 "Multifacetado, em razão de sua origem plural e da série de "aclimatações” porque passou nos diferentes países em que se manifestou (...) o Romantismo assimila as contradições histórico-sociais de sua época e as transforma em soluções estéticas”. MOISÉS, Massaud. "Indrodução". In: MOISÉS, Massaud. (org.) A Literatura Portuguesa em Perspectiva. São Paulo: Ed.Atlas S.A. 1994, VolumeIII Romantismo/Realismo,p. 11.

3 “Todas elas ( as escolas românticas nacionais) se podem considerar em relação a alguns acontecimentos importantes, que são principalmente: a Revolução Francesa, as guerras napoleônicas, a Restauração bourbónica francesa de 1815, as revoluções de 1830 e 1848 e movimentos correlativos"SARAIVA, António José \& LOPES, Óscar. História da Literatura Portuguesa. Portugal: Porto Editora, 1975, p.733.

${ }^{4} \mathrm{Na}$ tentativa de mapear os usos da palavra "Romantismo" nos reportamos ao significado oitocentista do termo em Portugal. De acordo com o Dicionário de Moraes Silva o verbete "romantismo" não consta, mas sim, "romàntico" e "romancismo". Verbete:"Romàntico, A, adj. (do Fr. romantique;adopt. Do Ing. romantic) Diz-se ordinariamente dos lugares, paizagens, vistas que recordam, tornam a trazer á memoria as descripções dos poemas e romances: v.g. sitio, vista - $\backslash$ Em litteratura diz-se, estylo -; e neste sentido é opp. a clássico.” Verbete: “Romancismo, s.m. Ficções, descripções romanticas. ”MORAES SILVA, Antonio de. Diccionario da Lingua Portuguesa. (Tomo II - F-Z), 6 a edição, $1^{\text {a }}$ edição de 1813 , Composto por Antonio de Moraes Silva. Lisboa: typographia de Antonio José da Rocha, Rua da Vinha, $\mathrm{n}^{\circ}$ 38 (Ao Bairro Alto), 1858, p.750. Já na etimoilogia de "romântico" encontramos: Verbete: "Romântico, adj. Do fr. romantique, já usado em 1694 pelo P. de Nicaise, mas vulgarizado durante o séc. XVIII, decalcado do ingl. romantic, que, por sua vez, provém do cit. voc.fr., a sua aplicação à literatura francesa verificou-se entre 1820 e 1830 (Bloch-Wartburg, s.v. roman).” Verbete: “Romantismo, s. Do fr. romantisme (1822)”. MACHADO, José Pedro.Dicionário Etimológico da Língua Portuguesa (Com a mais antiga documentação escrita e conhecida de muitos dos vocábulos estudados) - Quinto Volume (Q-Z). 1 ${ }^{\text {a }}$ edição de 1952, Lisboa: Livros Horizonte, 6 ${ }^{a}$ edição, 1990.

${ }^{5}$ LOWY, Michael \& SAYRE, Robert. Revolta e Melancolia - O romantismo na contramão da modernidade. Petrópolis, Rio de janeiro: Editora Vozes, 1995, p. 70.
} 
eram relacionadas à: "exaltação dos sentimentos, extravagância, maravilhoso,

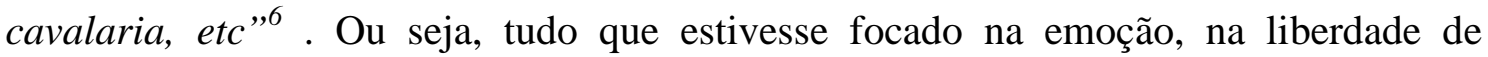
imaginação e de criação recebia esse epíteto. Essas características eram vistas como valores negativos, julgamento influenciado pelo modelo clássico, mas com o florescimento de uma nova sensibilidade estética, que começa na metade do século XVIII, esses valores se tornam positivos. Mas, somente na virada do século XIX, que o adjetivo irá se associar a um movimento filosófico-literário, que corresponde ao primeiro momento do romantismo alemão (o círculo de Jena).

Assim como o movimento em si, a palavra que o designa tem sido abordada sob diversos aspectos, muitas vezes contraditórios, revelando a profundidade e a extensão de temas que fazem parte da teia teórica do Romantismo. "De então para cá as palavras "romântico" $e$ "romantismo" têm sido usadas com variadíssimos $e$ contraditórios significados, de acordo com critérios de classificação de ordem psicológica, estética, ou até restritamente formal, temática, se não mesmo de ordem política ou moral" 7 .

De acordo com Massaud Moisés: "No sentido literário, o termo "romântico" foi empregado pela primeira vez na Inglaterra, em 1674, por Thomas Rymer (1641-1713), ao traduzir para o inglês (romantic) o vocábulo romanesque, usado por René Rapin (1621-1687).Na França, o registro pioneiro deve-se a Abbé Nicaise: "Que dites-vous, Monsieur, de ces pastoreaux, ne sont-ils pás bien romantiques?"(1640). A Alemanha, conheceu-o em 1698 (romantisch). Entretanto a difusão da palavra ocorreu a partir dos anos iniciais do século XIX. Idêntica circunstância cercou o aparecimento do termo “romantismo": na França (romantisme), em 1816, na Itália (romanticismo), em 1818, na Inglaterra (romanticism), em 1823, na Espanha (romanticismo), na segunda década do século XIX”. 8

Primeiramente, o Romantismo deve ser visto como consequiência do debate acerca dos rumos tomados pelo conhecimento filosófico iluminista ${ }^{9}$, que no seu empenho

\footnotetext{
${ }^{6}$ Idem, p.71.

${ }^{7}$ SARAIVA, António José \& LOPES, Oscar. História da Literatura Portuguesa. Portugal: Porto Editora, 1975, $8^{a}$ edição, p.725.

${ }^{8}$ MOISÉS, Massaud. Dicionário de Termos Literários. São Paulo: Editora Cultrix, $12^{\mathrm{a}}$ edição, 2004,pp.407 e 408.

${ }^{9}$ Que surge como inquisidor da realidade como um todo: “A filosofia já não significa, à maneira dessas novas perspectivas fundamentais, um domínio particular do conhecimento situado a par ou acima das verdades da física, das ciências jurídicas e políticas etc., mas o universal onde todas essas verdades formam-se, desenvolvem-se e consolidam-se. Já não está separada das ciências da natureza, da história, do direito, da política; numa palavra, ela é o sopro tonificante de todas essas disciplinas, a atmosfera fora da qual nenhuma delas poderia viver. Já não é a substância separada, abstrata, do espírito; oferece
} 
investigativo sobre as origens do saber humano e dos significados do mundo revela a gênese da formação de um novo edifício crítico, baseado nos critérios julgadores dos sentimentos individuais como medida de leitura da realidade. Essa nova instância de movimento cultural, herdeiro das Luzes e instigador de novos rumos de entendimento a respeito do ser e da $\operatorname{sociedade}^{10}$, abarca muitos autores que nessa transição de sensibilidade, configurada de maneira mais nítida no final dos setecentos, são chamados por muitos especialistas do período de "pré-românticos", justamente por apresentar uma produção ainda indefinida em seus traços estéticos. ${ }^{11}$

Dentre as idéias que inicialmente traçam o vínculo entre Ilustração e Romantismo, podemos destacar a repercussão, no século das Luzes, das obras de Locke e de Newton, que despontam como responsáveis pela redefinição do conhecimento na época, que passa de uma relação a priori para uma relação a posteriori da realidade, colocando deste modo, a análise empírica como elemento basilar da definição do conhecimento. "É a realidade que deve informar o conhecimento e não idéias, concebidas antes $e$ independentemente de sua verificação empírica, (...)"12.

“Não se busque, portanto, a ordem, a legalidade, a "razão”, como uma regra “anterior” aos fenômenos, concebível e exprimível a priori: que se demonstre a razão nos próprios fenômenos como a forma de sua ligação interna e de seu encadeamento imanente. Que não se pretenda antecipar a razão sob a forma de um sistema fechado: há que deixá-la desenvolver-se a longo prazo, pelo conhecimento crescente dos fatos, $e$ impor-se pelos progressos em sua clareza e em sua perfeição" ${ }^{13}$

Para Ernst Cassirer, a doutrina da estética clássica, postulada por regras e padrões poéticos universais e atemporais, sofre abalos significativos com a mudança da categoria do conhecimento, que passa a se afirmar a partir de princípios subordinadas aos fenômenos, à observação direta. Como isso, “(...) o método de explicação e de dedução tende cada vez mais, também nesse domínio, a ceder o lugar à pura descrição.

\footnotetext{
o espírito como um todo, em sua verdadeira função, no modo específico de suas investigações e de seus problemas, em seus métodos, no próprio curso do saber”. CASSIRER, Ernst. A Filosofia do Iluminismo. Tradução de Álvaro Cabral. São Paulo: Editora da Universidade de Campinas (UNICAMP), 1997, p.10.

10 "Segundo o parecer de Ernst Fische, e creio que perfeitamente aceitável, românticos como Shelley,Byron, Stendhal e Heine continuam a obra dos filósofos das Luzes”. FERREIRA, Alberto. Perspectiva do Romantismo Português (1833-1865). Lisboa, Portugal: Moraes Editora, 1979, p.10. 11 "Se não tivesse beneficiado da ajuda e da herança intelectuais do Iluminismo, jamais o Romantismo teria podido estabelecer e sustentar as suas posições”. CASSIRER, Ernst. Op.cit., p.267.

${ }^{12}$ GRESPAN, Jorge. Revolução Francesa e Iluminismo. São Paulo: Editora Contexto, 2003, p.49.

${ }^{13}$ CASSIRER, Ernst. A filosofia do Iluminismo. São Paulo: Editora da Universidade de Campinas, 1997, p.26.
} 
E essa descrição não parte mais das obras de arte mas da consciência estética cuja natureza ela quer, em primeiro lugar, reconhecer e definir. Já não são agora os gêneros artísticos que estão em causa, principalmente, mas as atitudes artísticas: a impressão que causa a obra de arte sobre aquele que a contempla e o julgamento no qual ele procura fixar essa impressão para si mesmo e para os outros ${ }^{\prime 14}$.

Com as palavras acima, fica claro que com uma mudança paradigmática do pensamento ilustrado, todos os campos do conhecimento científico e filosófico sofrem rupturas e reestruturações. No caso da estética, que de um julgamento normativo da obra de arte ascende uma espécie de "estética do efeito", ou seja, "busca-se mostrar que a obra de arte deve provocar determinada reação no sujeito ou no público ao qual se destina" ${ }^{\prime 15}$. Deste modo, assistimos ao advento da vontade humana como condicionante da produção artística e como valor do conhecimento, submetendo apreciações estéticas e as ações humanas ao subjetivismo e ao individualismo de cada um ${ }^{16}$.

Com a máxima da "análise dos fenômenos", a realidade como um todo, incluindo a conjuntura política, começa a ser questionada em seus valores tradicionais e nas suas bases de significação, abrindo novas possibilidades de construções sociais, políticas e econômicas (advento do fenômeno do "despotismo esclarecido", do pensamento liberal e de uma atitude revolucionária) para a Europa.

“A razão desliga o espírito de todos os fatos simples, de todos os dados simples, de todas as crenças baseadas no testemunho da revelação, da tradição, da autoridade; só descansa depois que desmontou peça por peça, até seus últimos elementos e seus últimos motivos, a crença e a "verdade pré-fabricada". Mas, após esse trabalho dissolvente, impõe-se de novo uma tarefa construtiva. (...). a razão (...) deverá construir um novo edifício, uma verdadeira totalidade (...)"17. Podemos dizer que a tarefa de “desmontagem" e de "construção do novo" será iniciada pelos iluministas e terá continuidade dentro do movimento romântico.

A análise da realidade que nasce a partir da preocupação com a observação e que leva a uma posterior tradução daquilo que foi observado, servirá de exemplo para a ação do homem romântico, que vê e relata aquilo que vê, utilizando-se da sua sensibilidade e

\footnotetext{
12CASSIRER, Ernst. A filosofia do Iluminismo. Campinas: Ed. da Unicamp, 1997, p.394.

${ }^{15}$ WERLE, Marco Aurélio. “Winckelmann, Lessing e Herder: Estéticas do Efeito?”In: Revista Trans/Form/Ação. São Paulo, 23: 19-50, 2000, p. 21.

16 “A vontade, portanto, é o elemento ativo que pode controlar as paixões, e não o raciocínio, agora rebaixado à condição de simples instrumento do desejo, limitando-se a escolher os meios adequados para realizá-lo” GRESPAN, Jorge, Op.cit., p.62.

${ }^{17}$ CASSIRER, Ernst. Op.cit. p.33.
} 
visão de mundo. Um exemplo disso é a relação de Rousseau e de Balzac com a cidade de Paris, local incansavelmente observado pelo olhar atento de ambos, e que será amplamente denunciada como lugar de solidão e como símbolo de códigos de conduta determinados por relações sociais vazias, fundadas no dinheiro para Balzac, e sem um único traço de afetividade real entre seus transeuntes.

Toda essa valorização do empírico, dos costumes (como forma de apreensão da realidade) e da construção do conhecimento a posteriori, como características próprias da Ilustração, resultará numa nova concepção cultural e humana, numa sensibilidade voltada ao desejo, à vontade individual e ao sentimento ${ }^{18}$. Movimento de idéias que desembocará na formação de uma sensibilidade romântica.

"O sentimentalismo romântico”, encarado com freqüência como situado nas fronteiras da Ilustração, além dos limites da razão, em decorrência do seu gosto pela natureza e pelo passado e sua estima pela fantasia e pela exaltação do instinto, marca, segundo P.Hazard, a desagregação do movimento ilustrado. O avanço do subjetivismo, os reclamos da "voz interior", cujo expoente é invariavelmente encarnado por um certo Rousseau, em lugar de serem encarados como uma outra face da mentalidade ilustrada, seu complemento natural, contendo em si a possibilidade de atenuar ou corrigir aquelas formas mais exaltadas do racionalismo, são com freqüência interpretadas como intrinsecamente contrários àquela mentalidade, numa simplificação excessiva e castradora da verdadeira totalidade da Ilustração". ${ }^{19}$

Desse modo, podemos afirmar que o grande expoente do Iluminismo que iria abrir, definitivamente, o caminho para a formulação das principais idéias de uma série de artistas e intelectuais denominados "pré-românticos" e para o próprio Romantismo, foi o filósofo Jean-Jacques Rousseau. A força do pensamento de Rousseau se concentra numa correspondência das idéias ilustradas, como a crítica de uma razão frívola como mediadora da conduta social, com um cabedal de novas propostas para a compreensão do comportamento e julgamento humano ${ }^{20}$. Como bem definiu Francisco Falcon a

\footnotetext{
${ }^{18}$ GRESPAN, Jorge. Op.cit. p.62. Nesse trecho, o autor trabalha com os citados temas, mostrando a crítica do racionalismo feita por Condillac, que altera a ordem das disposições cartesianas, colocando os sentidos como reguladores do raciocínio e das outras operações mentais, sendo que toda esta tese acarretará, posteriormente, e após o aparecimento das idéias de Rousseau no cenário das Luzes européias, no surgimento do "Sturm und Drang", movimento intelectual alemão do final do século XVIII, que contava com Goethe e Schiller, e que entre outras características, fazia a apologia do irracionalismo, das paixões, do instinto e da vontade individual como meio de transformação social e política.

${ }^{19}$ FALCON, Francisco José Calazans. A Época Pombalina (Política Econômica e Monarquia Ilustrada). São Paulo: Editora Ática (Ensaios 83), 1993, p. 104.

${ }^{20} \mathrm{O}$ pensamento de Rousseau é permeado por uma nova redefinição do sentimento, que antes fazia referência ao estímulo provocado pelos desejos e como emoção que deveria ser regrada, ou equilibrada,
} 
respeito desta "frivolidade" do homem ilustrado: "O homem esclarecido age sempre segundo os ditames do intelecto, não se deixando levar pelo sentimento e pela paixão. ${ }^{21}$

Jean-Jacques Rousseau revelando em seus escritos a disposição do sentimento afetivo como meio para buscar a transparência nas relações sociais, inaugura um campo teórico fecundo para o advento de uma verdadeira "revolução cultural", promovida algum tempo depois através dos pensadores do "Sturm und Drang" e do "préromantismo" em geral.

Talvez a obra mais significativa de Rousseau para o presente estudo seja Júlia ou A Nova Heloísa (1761) por trazer uma história de amor intermediada por discussões filosóficas baseadas numa nova maneira de compreensão do mundo, tendo o sentimento afetivo como ponto nevrálgico desses julgamentos.

“(...) La Nouvelle Héloise (1761) é, sobretudo, um romance sobre o amor como iniciação total a partir do sofrimento provocado pela paixão. Palavras como renascer e recomeçar surgem frequentemente, estando a experiência amorosa ligada à dolorosa experiência do efêmero existencial (...),22

O romance de Rousseau é dividido em várias cartas, que revelam os arroubos da paixão amorosa e indicam uma correspondência das disposições de um espírito apaixonado, tocado por uma intensa sensibilidade, com o nascimento duma particular visão de mundo baseada numa integração afetiva entre as relações humanas e a natureza.

Sobre essas questões, vejamos o que Saint-Preux escreve para sua amada: "Não, Júlia, não me é possível não ver-te a cada dia senão como te vi na véspera: é preciso que meu amor aumente e cresça sem cessar com teus encantos, e és para mim uma fonte inesgotável de sentimentos novos que nem mesmo teria imaginado (...) Acho o campo mais alegre, a verdura mais fresca e mais viva, o ar mais puro, o Céu mais sereno; o canto dos pássaros parece ter mais ternura e voluptuosidade, o murmúrio das águas inspira um langor mais amoroso, a videira florida exala ao longe mais doces perfumes, um encanto secreto embeleza todas as coisas ou fascina meus sentidos, dir-

para evitar excessos. Em Rousseau o sentimento nasce de uma disposição afetiva que permeia todas as relações e que se torna responsável pela aproximação dos espíritos, as partes sensíveis do seres humanos, portanto, os sentimentos, os afetos, devem ser vividos com toda intensidade e profundidade.

${ }^{21}$ FALCON, Francisco José Calazans. A Época Pombalina (Política Econômica e Monarquia Ilustrada). São Paulo: Editora Ática (Ensaios 83), 1993, p. 100.

${ }^{22}$ MACHADO, Álvaro Manuel. As origens do Romantismo em Portugal. Lisboa: Livraria Bertrand, Coleção Biblioteca Breve, volume 36, 1979, p. 37. 
se-ia que a terra enfeita-se para formar, para teu feliz amante, um leito nupcial digno da beleza que adora e do fogo que o consome"23.

Além dessa relação de continuidade com algumas idéias da Ilustração, o Romantismo só se estabelece como movimento artístico e como visão de mundo, a partir da efetivação das mudanças econômicas e sociais advindas do desenvolvimento industrial da Europa e das conseqüências das Revoluções liberais em muitos países.

Historicamente, o Romantismo é situado por diversos autores como movimento ou fenômeno histórico decorrente das Revoluções Francesa e Industrial ${ }^{24}$. Para a crítica de autores como Hobsbawm, Nachman Falbel e Elias Thomé Saliba ${ }^{25}$, o Romantismo surge como resposta para as mudanças políticas, econômicas e sociais que desestruturaram a Europa do período (final do século XVIII até metade do século XIX).

O mundo da intelectualidade européia sofrera alterações radicais com o desenvolvimento econômico, que passa a ser impulsionado, gradativamente, através da produção em larga escala e maximização dos lucros nas relações comerciais, desse modo, o homem torna-se uma mera engrenagem dentro da política econômica do capitalismo industrial. "Em meio à grande expansão econômica, ao súbito enriquecimento de uma minoria, da desabalada corrida dos inventos e inovações no setor tecnológico, e à crença na prosperidade e progresso humanos, surgiram graves problemas de ordem social em relação às massas de trabalhadores que este processo mobilizava e proletarizava”, (...). “A precariedade das instalações industriais, a falta de segurança, as péssimas condições higiênicas dos locais onde mulheres e crianças constituíam a mão-de-obra ao lado de homens, respirando o ar contaminado das

\footnotetext{
${ }^{23}$ ROUSSEAU, Jean-Jacques. Júlia ou A Nova Heloísa. São Paulo-Campinas: Hucitec/Editora da Unicamp, 1994, pp. 114 e 115.

${ }^{24}$ De acordo com a visão de Eric J. Hobsbawm a "literatura romântica", que enquadra a produção de poesias, peças de teatro e, especialmente, romances, surgiu sob os efeitos da denominada "dupla revolução”. O termo aparece logo no prefácio de seu livro A Era das Revoluções e é usado para caracterizar as transformações que o mundo sofreu entre 1789 e 1848, motivadas pelas Revoluções Francesa e Industrial. Sobre as condições históricas do Romantismo o historiador escreve: “Em um sentido estrito, o romantismo surgiu como uma tendência militante e consciente das artes, na GrãBretanha, França e Alemanha, por volta de 1800 (no final da década da Revolução Francesa), e em uma área bem mais ampla da Europa e da América do Norte depois da batalha de Waterloo. Foi precedido antes da Revolução (principalmente na Alemanha e na França) pelo que tem sido chamado de "préromantismo" de Jean-Jacques Rousseau, e a "tempestade e violência" dos jovens poetas alemães. Provavelmente, a era revolucionária de 1830-48 assistiu a maior voga européia do romantismo. No sentido mais amplo, ele dominou várias das artes criadoras da Europa, desde o começo da Revolução Francesa" HOBSBAWM, Erich. A Era das Revoluções (1789-1848). Rio de Janeiro: Editora Paz e Terra, 1982, p.280.

${ }^{25}$ FALBEL, Nachman. "Fundamentos Históricos do Romantismo”. In: GUINSBURG, J. O

Romantismo. São Paulo: Editora Perspectiva, 1978. HOBSBAWM, Erich. Op.cit. SALIBA, Elias Thomé. As utopias românticas. São Paulo: Editora Estação Liberdade, 2003.
} 
minas, das oficinas mal instaladas, tudo isso convertia o período em um dos mais cruéis para a grande massa que sempre viveu do suor do rosto" ${ }^{, 6}$.

O Romantismo, como fenômeno histórico, traça para si, fator que irá defini-lo como movimento artístico e como visão de mundo, a tarefa de crítico dos aspectos negativos do capitalismo industrial e do conjunto de valores sociais e morais defendidos pela burguesia ${ }^{27}$.

No bojo dessas idéias podemos citar o posicionamento de António José Saraiva em acordo com a questão defendida. Para ele, o individualismo ou subjetivismo romântico estava ligado a uma "reação a formas novas de envilecimento humano, e até paisagísticos, acarretadas pela onipotência do dinheiro, agora sem entraves às suas funções capitalistas, e pela revolução industrial da máquina a vapor alimentada a carvão" 28 . Aqui, em outras palavras, o autor coloca a valorização do eu, tema recorrente no Romantismo, como medida crítica à mediocridade humana gerada e alimentada pelo capitalismo industrial.

Assim como António José Saraiva, também Arnold Hauser identifica no Romantismo uma crítica à nova ordem burguesa ${ }^{29}$, a partir da perda de referenciais políticos, sociais e econômicos. Reportando-se às consequiências da Revolução Industrial, este afirma: “A Idade Média, com todos os seus vestígios, seu espírito corporativo, suas formas particulares de vida, seus métodos irracionais e tradicionais de produção, desaparece de uma vez para sempre, dando lugar a uma organização do trabalho baseada exclusivamente em razões de oportunidade e cálculo, aliadas a um espírito de implacável individualismo competitivo. (...). Artesãos, ganha-dinheiros,

\footnotetext{
${ }^{26}$ FALBEL, Nachman. Op.cit. p. 29.

${ }^{27}$ No presente trabalho o conceito "burguesia" é entendido como o conjunto de homens, que representados como classe, defendiam um posicionamento diante do mundo em absoluta correspondência com o desenvolvimento industrial da sociedade capitalista. A ordenação das relações econômicas, sociais e políticas como visão de mundo burguesa estabelecia: “(...) o nivelamento dos valores morais à regra benthamiana do maior interesse e da melhor utilidade, a marginalização social de toda atividade improdutiva, o princípio fiduciário da moralidade burguesa, as relações possessivas da moral doméstica e do casamento, a separação entre as esferas sexual e sentimental do amor, (...)" NUNES, Benedito. "A Visão Romântica". In: GUINSBURG, J. Op.cit. p.55.

${ }^{28}$ SARAIVA, António José \& LOPES, Oscar. Op.cit.p. 727.

${ }^{29}$ Nova ordem burguesa que surge como norteadora das relações humanas a partir dos eventos da "dupla revolução", tendo suas exigências atendidas em detrimento dos valores da antiga ordem feudal. "Mais especificamente, as exigências do burguês foram delineadas na famosa Declaração dos Direitos do Homem e do Cidadão, de 1789. Este documento é um manifesto contra a sociedade hierárquica de privilégios nobres, mas não um manifesto a favor de uma sociedade democrática e igualitária. "Os homens nascem e vivem livres e iguais perante as leis”, dizia seu primeiro artigo; mas ela também prevê a existência de distinções sociais, ainda que "somente no terreno da utilidade comum". A propriedade privada era um direito natural, sagrado, inalienável e inviolável. Os homens eram iguais perante a lei e as profissões estavam abertas ao talento" HOBSBAWM, Erich. Op.cit. p. 77.
} 
camponeses sem terra, operários especializados e mão-de-obra não qualificada, homens, mulheres e crianças, todos se convertem em meros braçais de uma enorme fábrica que funciona mecanicamente nos moldes de um quartel. A vida perde sua estabilidade e continuidade, todas as suas formas e instituições são deslocadas e se encontram em permanente câmbio" ${ }^{30}$.

Segundo Hauser, essas mudanças estruturais da sociedade provocaram na sensibilidade romântica um "protesto contra a mecanização" e uma crítica da "despersonalização da vida relacionados com uma economia deixada à rédea larga”, aliada a uma "profunda melancolia que se apodera das almas" e o "anseio de uma mundo longínquo e desconhecido, distante do presente" ${ }^{31}$.

A realidade histórica vivida pelos românticos se estabelecia por uma descaracterização das relações humanas e por novos horizontes políticos indefinidos, que ora vigoravam cheios de problemas e causadores de novos males sociais e ora como lugares privilegiados para utopias sociais. Afirmando essa idéia, o Romantismo formouse como elemento de revolta relacionado a um sentimento de frustração diante do progresso material e econômico, promovido pelos avanços industriais, e como conseqüência dos rumos da Revolução Francesa, marcados pelo período do Terror e da dominação napoleônica na Europa, que causaram adesão por parte de alguns românticos e repulsa por parte de outros.

Dentre os autores analisados que se reportam ao Romantismo como elemento crítico da modernidade, entendida no presente estudo, como modelo civilizatório alicerçado no avanço industrial regulador das esferas sociais, políticas, econômicas e culturais, Michael Lowy e Robert Sayre aparentam ser os que mais veementemente afirmam essa idéia.

Ambos tratam o Romantismo como um movimento de diversas características e de muitas vertentes, razões desnorteadoras na determinação exata desses elementos por parte dos especialistas, mas que para os autores em questão, essa miríade de formas assumidas pela estética romântica apresenta um dado unificador. Esses autores acreditam que numa análise mais atenta pode-se notar, nos escritores e artistas românticos, uma visão de mundo comum e partilhada entre os mesmos.

\footnotetext{
${ }^{30}$ HAUSER, Arnold. História Social da Arte e da Literatura. São Paulo: Martins Fontes, 1995, pp.553 e 554 .

${ }^{31}$ Idem, p.560.
} 
Seguindo a fórmula de Ernst Cassirer em relação a sua tentativa de compreender o pensamento ilustrado, podemos traçar o mesmo julgamento analítico feito pelo citado autor, no que diz respeito ao pensamento romântico.

Da mesma forma que Cassirer,os autores já citados, Michael Lowy e Robert Sayre querem compreender o movimento romântico "não na totalidade dos seus resultados $e$ de suas manifestações históricas, mas na unidade de sua fonte intelectual e do princípio que a rege ${ }^{, 32}$.

A determinação da visão de mundo apresentada constitui-se como ponto nevrálgico para uma compreensão mais profunda do Romantismo, ou seja, mostra-se como uma pista de interpretação explorada de maneira redutora pelos críticos e historiadores do Romantismo ${ }^{33}$.

A visão de mundo romântica, Weltanschuung, é baseada no passado como referência, mostrando o caráter essencialmente histórico do Romantismo ${ }^{34}$, de valores e questões éticas, mas sendo, muitas vezes, um passado que de fato nunca existiu, mas foi interpretado e recriado como idéia de modelo social, como utopia romântica ${ }^{35}$. Desse modo o dado unificador que as muitas variantes do Romantismo carregam consigo, encontra-se, justamente, na visão de mundo passadista julgadora da modernidade, que sob um viés nostálgico se determina como elemento de mudança e superação das relações sociais dadas pela ordem industrial ${ }^{36}$.

Assim sendo, para Lowy e Sayre, “(...) o Romantismo é, por essência, uma reação

\footnotetext{
${ }^{32}$ CASSIRER, Ernst. A Filosofia do Iluminismo. São Paulo: Editora da Universidade de São Paulo (UNICAMP), 1997, p.7.

${ }^{33}$ LOWY, Michael e SAYRE, Robert. Revolta e Melancolia - O romantismo na contramão da modernidade. Petrópolis, Rio de Janeiro: Editora Vozes, 1995, p.20.

${ }^{34}$ Sobre a origem do Romantismo, Lowy e Sayre a identificam com o avanço da modernização em determinados países. "Antes de mais nada, parece que o "núcleo" ou centro do fenômeno poderá ser situado em três países - França, Inglaterra e Alemanha. Com efeito, é nesses países relativamente "desenvolvidos" que, na segunda metade do século XVIII, o Romantismo surge mais cedo, de uma forma mais intensa e de maneira mais pronunciada. Além disso, esses países exerceram, em outras partes e ulteriormente, uma influência maciça sobre o desabrochamento e desenvolvimento dos romantismos" Idem, p.79.

${ }^{35}$ Sobre as utopias românticas, podemos dizer ainda: "Toda a sua política (tendo como ponto de referência as motivações românticas), em seu amplo significado, passou a traduzir-se num constante e reiterado apelo ao ideal; as representações e as imagens, e as idéias delas advindas, foram consideradas forças incomensuráveis de transformação completa da história e da sociedade” SALIBA, Elias Thomé. Op. cit. p. 36.

36 "A nostalgia de um paraíso perdido é acompanhada, quase sempre, por uma busca do que foi perdido" (...) "Esse impulso pode se manifestar pelo surgimento do sobrenatural, do fantástico, do onírico, ou então, em determinadas obras de arte, pela tonalidade do "sublime". No entanto, em outro sentido, toda criação artística romântica é uma projeção utópica - um mundo de beleza - criada pela imaginação no momento em que é concebida". LOWY, Michael e SAYRE, Robert. Op.cit. p.42. Para ilustrar essa idéia podemos citar a proposta de poetização ou estetização do presente de Schiller e Novalis, que toma o mundo como local de referências com o transcendente e que só pode se realizar plenamente, integrando o universal no particular, através da poesia, vista como "linguagem do mundo".
} 
contra o modo de vida da sociedade capitalista (...), portanto, (surge) na segunda metade do século XVIII e ainda não desapareceu"37. Logo, podemos afirmar que os autores em questão identificam o Romantismo com o advento da sociedade capitalista estruturada de maneira mais nítida na primeira Revolução Industrial, final do século XVIII. O Romantismo é encarado como visão de mundo interligada com a crítica que envolve as características do fenômeno capitalista e da modernidade ${ }^{38}$, e, para esses autores, o movimento romântico pode ter se encerrado como escola literária e artística, mas não como ponto crítico de análise.

O movimento, como crítico e construtor de valores, é traduzido nas palavras do romântico alemão Novalis: "O mundo deve ser romantizado. Assim reencontraremos o sentido originário. Romantizar não é nada mais do que uma que uma potencialização qualitativa. O si inferior, nessa operação, identifica-se com um si melhor. Assim, nós mesmos seríamos somente uma série qualitativa, de potências desse tipo. Essa operação é ainda totalmente desconhecida. Na medida em que dou ao comum um sentido elevado, ao habitual um aspecto misterioso, ao finito uma aparência infinita, ao conhecido a dignidade do desconhecido, eu o romantizo. Inversa é a operação para o mais-alto, o desconhecido, o místico, o infinito [...] $]^{\text {39 }}$.

\subsection{Ilustração portuguesa - a idéia de "decadência" cultural:}

Do mesmo modo que a Ilustração e o Romantismo, em seus aspectos gerais de movimento cultural, foram responsáveis por um instigante e indissociável intercurso de idéias, no caso da trajetória cultural portuguesa também é possível estabelecer algumas relações de vínculo entre o pensamento de seus principais representantes tanto do movimento ilustrado quanto do romantismo português na sua primeira geração. Ambos os fenômenos, associados à realidade histórica de Portugal, debruçaram-se sobre mudanças estruturais (sociais e econômicas) aparentemente divergentes ${ }^{40}$ da história

\footnotetext{
${ }^{37}$ Idem, p. 33.

38 “Como já tinha sido verificado por Max Weber, as principais características da modernidade - o espírito de cálculo (Rechnenhaftigkeit), o desencantamento do mundo (Entzauberung der Welt), a racionalização instrumental (Zweckrationalitat), a dominação burocrática - são inseparáveis do advento do "espírito do capitalismo" Idem, p.35.

${ }^{39}$ NOVALIS. In: BERMANN, Antoine. A prova do estrangeiro: A cultura e tradução na Alemanha romântica: Herder, Goethe, Schlegel, Novalis, Humboldt, Scheiermacher, Holderlin. Tradução de Maria Emília Pereira Chanut. Bauru, São Paulo: Edusc, 2002, p. 140.

${ }^{40}$ A ilustração portuguesa, analisada sob o foco dos projetos dos estadistas luso-brasileiros, tentou criar mecanismos para a continuidade do Estado Absolutista português. Já a primeira geração romântica portuguesa, enfocada sob as idéias de seus principais autores, Garrett e Herculano, pertenceu a um
} 
portuguesa, mas que tocaram num mesmo ponto central: a reorganização dos sentidos políticos em Portugal em seu contexto cultural.

A Ilustração portuguesa, encarada aqui, através das idéias dos estrangeirados (diplomatas e homens ligados à administração portuguesa) e dos estadistas lusobrasileiros (intelectuais atuantes na política portuguesa durante o período mariano e joanino) esteve na sua heterogênea produção intelectual (reflexões sobre a política externa em Portugal; medidas políticas que deveriam ser adotadas para aplacar os problemas econômicos no Reino e nas Colônias, particularmente o Brasil e uma lista de livros sobre as potencialidades econômicas brasileiras) preocupada, com a integridade territorial do Império português e com a busca de uma nova identidade política e cultural (preocupações que iriam originar a idéia de "Império luso-brasileiro").

Da mesma forma que a Ilustração, a primeira geração romântica portuguesa, com nomes como Alexandre Herculano e Almeida Garrett, estava disposta em definir novas balizas culturais para Portugal, através do constante diálogo com a produção cultural do final dos setecentos e dos oitocentos da Europa, e em afirmar uma nova configuração para a identidade política portuguesa, através da participação nos movimentos políticos portuguesa dos anos 30 e 40 do século XIX, como na Revolta Setembrista, com a edição de seus romances históricos e pela reflexão sobre a história portuguesa e os movimentos políticos vividos em livros e artigos de jornal.

As idéias iluministas entram em Portugal, de uma maneira mais objetiva, com o consulado pombalino, iniciado a partir de 1750, que toma estas idéias como suporte de reflexão para os rumos políticos do Império português, denunciado em seu "atraso" mental (cultural) e econômico desde a experiência do estrangeiramento (grupo de intelectuais portugueses e luso-brasileiros, diplomatas em sua grande maioria, como no caso de D.Luís da Cunha, que transitaram em diversos países da Europa e das colônias portuguesas, e que pensaram, bafejados por idéias fora do tradicional campo intelectual português, uma renovação de medidas políticas para o Império Luso- brasileiro).

O historiador Francisco Falcon aponta uma espécie de "mentalidade conservadora", presente em Portugal, desde o período das grandes navegações e conquistas coloniais, e atuante, de maneira mais visível, até o início do século XVIII, avessa a todo tipo de novidade que pudesse questionar as suas tradicionais disposições

período posterior da história de Portugal, foram contemporâneos dos conflitos envolvendo a instauração da Monarquia Constitucional e do Liberalismo em Portugal. 
políticas, administrativas, econômicas e religiosas ${ }^{41}$, e que iria ser combatida por um determinado grupo de intelectuais portugueses, que viajando para outros locais do continente, acabavam absorvidos por uma ambiência cultural européia e assumiam uma postura de combate frente ao "atraso" de Portugal em relação à conjuntura histórica do restante da Europa. ${ }^{42}$

"Fortalecem-se mutuamente, dialeticamente, desde o século XVI: Companhia de Jesus e Tribunal do Santo Ofício, de um lado; “cristãos-novos” e "estrangeirados", do outro. Nesse sentido é válido afirmar que, a rigor, a modernidade só irá ter lugar efetivamente no século XVIII, anunciando-se sob D.João V e desencadeando-se, como processo, sob D.José I"43.

Podemos perceber uma forte presença dos meios eclesiásticos, exemplarmente dos jesuítas, atuando na vida política e educacional do país até as mudanças definidoras do século XVIII. Prova disso era a atuação dessa ordem religiosa na Universidade de Coimbra, baluarte da escolástica e do tradicionalismo teológico, que foi alvo da crítica de muitos "estrangeirados", como de D.Francisco Xavier de Menezes (1674-1743) (4 Conde de Ericeira) e do frade teatino P.Rafael Bluteau (1638-1734) e da ordem dos oratorianos. $^{44}$

Tanto Francisco Falcon quanto Hernani Cidade ${ }^{45}$ apontam a importância dos oratorianos na constituição de um novo caráter para o ensino em Portugal, que deveria estar mais voltado aos métodos científicos e de análise empírica da Ilustração e afastado de uma estrutura pedagógica eclesiástica "arcaica" e "barroca".

Com a fundação em Roma da Congregação do Oratório de São Felipe de Nery, em 1550, e sua subseqüente introdução em Portugal, em 1668, pelo Padre Bartolomeu do

\footnotetext{
${ }^{41}$ FALCON, Francisco José Calazans. Op.cit. p. 152.

${ }^{42}$ Sobre a questão do "estrangeiramento” podemos defini-lo: “(...) como sendo o produto de uma cisão entre aqueles que, viajando e conhecendo outras realidades, ou, entrado em contacto com os que vinham de fora, militares e diplomatas de outras nações, puderam mudar suas maneiras de ver e de sentir, e os demais que, insulados, ficaram impermeáveis a tudo que viesse do estrangeiro. Foi este o ponto de partida para a divisão ideológica entre os nacionais ou “castiços” e os “estrangeiros” (...)”. FALCON, Francisco José Calazans. Op.cit. p.204.

${ }^{43}$ FALCON, Francisco José Calazans. Op.cit. p.152.

44 “Criticavam todos ("estrangeirados") instituições tidas e havidas por sagradas - o absolutismo arbitrário, os privilégios de casta, o fanatismo da inquisição, o domínio do ensino pelos jesuítas, o atraso enfim de Portugal em relação à cultura científica européia” NOVAIS, Fernando A. Portugal e Brasil na Crise do Antigo Sistema Colonial (1777-1808). São Paulo: Editora Hucitec, 2001, p. 221.

45 "Foi a pedagogia oratoriana que entre nós desenvolveu, com efeito, o estudo das ciências experimentais e da filosofia moderna que as fecundava e estimulava” CIDADE, Hernani. Lições de Cultura e Literatura Portuguesas (Da Reacção contra o Formalismo Seiscentista ao advento do Romantismo). Coimbra: Coimbra Editora Limitada, 1984, Segundo volume, p.161.
} 
Quental, inaugurou-se o palco de acirradas disputas nos meios eclesiásticos portugueses entre jesuítas e oratorianos.

“Oratorianos e jesuítas, em rivalidade surda desde o início, entraram em choque a partir da concessão régia, em 1708, que reconheceu aos egressos das escolas oratorianas os mesmos direitos que tinham aqueles saídos das classes jesuíticas. A luta desenvolveu-se em diversas etapas, quase todas terminando com vitórias do Oratório: 1716,1725,1747. Quebrava-se o monopólio jesuítico, mas não o eclesiástico, no campo decisivo da pedagogia" ${ }^{46}$.

Os oratorianos introduziram nos meios educacionais portugueses um estudo sistemático da língua materna, da história, da geografia e das ciências naturais, aliando um ecletismo de inclinações teóricas (de viés religioso e laico). “A princípio, através de Pierre Bérulle, inclinaram-se (os oratorianos) para o platonismo - era uma forma de rejeitar o aristotelismo (base da escolástica ibérica). Aos poucos, contudo, o cartesianismo penetrou nos Colégios dos Oratorianos, da mesma forma e na mesma época em que penetrava em Port Royal, mas sem dominar totalmente; seu ascetismo teocêntrico e interiorista evitou-lhes os excessos racionalistas sem impedir, todavia, que a preocupação com o método produzisse uma reforma do ensino (...),47

Papel de destaque e de amadurecimento do movimento ilustrado português, apontado por Francisco Falcon ${ }^{48}$ e Hernani Cidade ${ }^{49}$, coube à figura do "estrangeirado" Luís Antônio Verney (1713-1792) e da publicação de suas dezesseis cartas em Roma, nos anos de 1746 e 1747, sob o título de "Verdadeiro método de estudar”. Essas cartas foram responsáveis por inaugurar um novo "espírito crítico" em relação ao ensino ${ }^{50}$ existente em Portugal e de constituir um prognóstico negativo em relação à cultura portuguesa como um todo.

Assumindo uma missão de difusor cultural, Verney inaugurou uma atitude de questionamento das "tradições" portuguesas sob o ponto de vista do pensamento moderno ilustrado, tudo que era aceito sem questionamento deveria ser rigorosamente

\footnotetext{
${ }^{46}$ FALCON, Francisco José Calazans. Op.cit. p.209.

${ }^{47}$ FALCON, Francisco José Calazans.Op.cit. p.209.

48 "Nesse universo mental, dominado em larga escala pelo marasmo, pela estagnação, o abalo e o corte só se verificam realmente com o Verdadeiro método de estudar." Idem, p.157.

49 " $O$ "Verdadeiro método de estudar", de todos os seus trabalhos o de maior repercussão, foi publicado de 1746 a 1747. Nada melhor do que ele evidencia o atraso que ainda nos distanciava do mundo culto, (...)” CIDADE, Hernani. Op.cit. p.102.

50 “O Verdadeiro Método foi, acima de tudo, um despertador. Produziu um choque psicológico nas massas cultas, trazendo para liça pública, em corpo inteiro, idéias e questões anteriormente confinadas a murmúrio dos cenáculos ou à meia voz dos livros” FALCON, Francisco José Calazans. Op.cit. p. 337.
} 
analisado com base nas leis políticas, econômicas e culturais de toda uma Europa "esclarecida".

Sobre os aspectos gerais e inovadores do pensamento de Verney, o historiador Francisco Falcon escreve: "Em primeiro lugar, o discurso verneyano representa um corte com as tendências cartesianas e gassendistas vigentes entre os "estrangeirados" do primeiro meio século luso. É, agora, de Locke e, sobretudo, de Newton que se trata. Em segundo lugar, é a ruptura da mentalidade ilustrada com a barroca, em todos os níveis da sociedade. É o declínio da metafísica e o Ascenso da física, da lógica e da ética natural, o "nascimento das ciências humanas". Finalmente, é uma ruptura que pretende, simultaneamente, preservar o essencial - a fé católica-(...)"51.

As primeiras tentativas de renovação cultural (voltada a uma preocupação pedagógica própria das Luzes) se realizaram com os estrangeirados no reinado de D.João V, sendo os nomes de maior destaque: D.Luís da Cunha (1662-1749), Luís Antônio Verney (1713 - 1792) e Ribeiro Sanches (1699-1783); todos comprometidos com o setor aristocrático da sociedade portuguesa ${ }^{52} \mathrm{e}$, portanto, com uma reforma ampla da sociedade lusitana advinda dos interesses dos estratos sociais superiores.

Estes primeiros ilustrados setecentistas foram influenciados por todo um amplo pensamento econômico e intelectual iluminista e que, através de uma análise empírica dos problemas portugueses (que acarretariam num desvendar de uma crise do antigo sistema colonial - a denominada decadência econômica) fundamentados historicamente, passariam a ter como missão o enfrentamento do atraso cultural do Reino, e solucionar a questão econômica do Império.

A constatação deste atraso cultural da sociedade portuguesa tinha como fator a predominância de esferas sociais tradicionais (de natureza nobiliárquica-eclesiástica) como norteadoras culturais e da decadência econômica como fruto de políticas administrativas metropolitanas e coloniais ultrapassadas para os novos rumos econômicos europeus e a dependência financeira diante das potências européias, especialmente, a Inglaterra.

Para tentar resolver a questão do atraso cultural, foi proposto um gradativo afastamento do pensamento escolástico da esfera pública/política e a sua substituição pelo moderno e laicizado espírito científico preconizado pela Ilustração. Como no caso

\footnotetext{
${ }^{51}$ Idem, p. 332.

${ }^{52}$ Ibidem, p.37. Neste trecho de seu trabalho, Ana Rosa Cloclet da Silva trata a reflexão dos estrangeirados como diagnósticos ilustrados dos "males" da sociedade portuguesa que impediam os caminhos para uma modernização econômica e política.
} 
de D.Luís da Cunha que se opunha ao "governo absoluto dirigido pela Companhia de Jesus, pelo Santo Ofício e pela influência estrangeira" $"$.

Ainda pensando no bojo destas iniciais idéias pedagógicas, que tinham como função última, a reforma da atuação do Estado português visando um maior contorno laico da política, ressaltamos novamente a obra de Luís Antônio Verney - o Verdadeiro Método de Estudar, de 1746 - que traça uma crítica ao ensino preconizado em Portugal, fortemente imbuído de uma mentalidade tradicional escolástica, em prol de uma proposta pedagógica centrada no empirismo de Locke e Newton (os precursores do conhecimento formulado com base na observação da realidade) e na experiência histórica (subentendida com base numa valorização do passado português). Vale destacar que o sentido de ruptura da obra de Verney "não estava num embate contra a "fé católica" - uma vez que se almejava o próprio firmamento da teologia em bases mais sólidas" ${ }^{54}$.

A obra de Verney abriu um fecundo diálogo entre "antigos" e "modernos", pensamento "religioso" e "laico", inaugurando um sentido de análise e crítica reaproveitado pelos futuros liberais "românticos", que da mesma maneira, refletiram os problemas e impasses de Portugal com base num discurso historicamente fundamentado e, ao mesmo tempo, comprometido com as idéias e atitudes contemporâneas.

Como exemplo dessa nova atitude, tipicamente ilustrada, de reorganização do passado com vista num maior entendimento dos "costumes" presentes, cabe destacar a influência de Vico ${ }^{55}$ e do papel de destaque do ensino da História, presente em Verney. "A História - estudo das realidades políticas e sociais - quer Verney, contra os seus adversários, que acompanhe o estudo da Jurisprudência Civil ou Canônica, o da própria Teologia (...), assim como defende que o estudo da História da Filosofia deve auxiliar o estudo desta disciplina. É, como se vê, pelo que respeita ao estudo do Direito, o primeiro passo no caminho que leva à escola de Savigny, como, de modo geral, aos métodos do nosso tempo: integrar a criação do espírito nas realidades que a

\footnotetext{
${ }^{53}$ CUNHA, D.Luis. Testamento político. São Paulo: Alfa-Ômega, 1976, p.XV. Citação feita por Ana Rosa Cloclet da Silva. Op.cit. p.40

${ }^{54}$ SILVA, Ana Rosa Cloclet. Op.cit. p.51.

55 Verney era um "estrangeirado" que viveu e absorveu a cultura italiana do período. Sobre isso, Hernani Cidade não deixa de considerar a marcante presença de Vico (1668-1744) na Itália da primeira metade do século XVIII que Verney conheceu. O "gênio de Vico (...) abre na sua cadeira de professor de Retórica perspectivas novas sobre os mistérios da língua e da poesia das primeiras idades, por elas entrevendo o próprio processus da evolução humana” CIDADE, Hernani. Op.cit. p.101.
} 
determinam, o abstrato no concreto, a forma transitória na perenidade de dinâmica da Vida" ${ }^{, 56}$.

Assim como Luís Antônio Verney, a figura do médico português Antônio Nunes Ribeiro Sanches foi importante para introduzir a perspectiva do pensamento ilustrado em Portugal, através de sua valorização da experimentação e da observação no campo científico $^{57}$, e de seu estudo na área pedagógica.

Como "estrangeirado", Ribeiro Sanches estabeleceu um profícuo diálogo com os principais centros científicos da Europa ilustrada, foi eleito sócio correspondente das Academias das Ciências de Paris, Berlim e São Petersburgo e atuou como membro da Sociedade Real de Londres.

Além do seu trabalho específico no campo da medicina, Ribeiro Sanches, compactuando do espírito reformista das Luzes, refletiu sobre a realidade portuguesa, principalmente na sua face pedagógica. Assim como o "Verdadeiro Método de Estudar" de Verney, suas "Cartas sobre a educação da mocidade nobre” exerceram um forte impacto na nova imagem que a educação moderna portuguesa queria mostrar. $^{58}$

O plano básico das "Cartas" de Ribeiro Sanches aponta para uma ampla secularização do ensino, tendo o Estado português como ideólogo e organizador da educação de uma elite cultural e bem preparada para enfrentar e superar a "decadência" cultural e econômica de Portugal.

Para Ribeiro Sanches, a educação reformada deveria integrar os jovens nobres na vida do seu tempo, preparando-os melhor para uma vida administrativa aos moldes das monarquias "esclarecidas" européias. O médico ilustrado imaginou “(...) uma escola militar para nobres, com muito exercício para o desenvolvimento da agilidade e robustez - ginástica, esgrima, dança - mas também com línguas modernas castelhano, francês, inglês - Matemáticas elementares, Geografia e História, princípios de Direito Civil, Político e Pátrio, além de conhecimentos de armas, evoluções e táctica." 59

\footnotetext{
${ }^{56}$ CIDADE, Hernani. Op.cit. p.137

57 “O artigo que publicou na "Encyclopédie" de D’Alembert e Diderot, sobre o mal venéreo, e que tanto espanto causou ao seu biógrafo e contemporâneo, o anatomista Vicq d'Azir, ainda hoje é considerado como uma aguda penetração nesse mistério patológico”. .Idem, p.57.

58 "O que se sabe, é que foi em conformidade com o plano exposto nessas Cartas que o conde de Oeiras, futuro marquês de Pombal, organizou em 1761 o Colégio dos Nobres.” Ibidem, p.59.

${ }^{59}$ Ibidem, p. 59.
} 
Como medidas para resolver o impasse econômico (a "decadência" da economia lusitana, como queriam os "estrangeirados") foi colocado como centro norteador destas questões a necessidade de desenvolver a indústria e a agricultura no território nacional $^{60}$, diminuir os benefícios econômicos encontrados pelos ingleses, como à exportação dos vinhos portugueses e a continuidade, da maneira como foram estabelecidos, dos tratados internacionais, e realizar um maior controle do território colonial (gerindo melhor suas riquezas e potencialidades econômicas, principalmente da colônia americana). Em suma, o que estava se firmando a partir deste momento na trajetória econômica em Portugal, era o surgimento duma mentalidade capitalista, inspirada por princípios do liberalismo econômico e voltada a um empreendimento das atividades financeiras relativas ao Reino e colônias.

A análise empírica da situação política e econômica em Portugal, como já foi exposto anteriormente, mostrará, para uma geração posterior de intelectuais formados sob os auspícios da Academia das Ciências de Lisboa (criada em 1779), os caminhos irreversíveis de uma crise do antigo sistema colonial, e D.Luís da Cunha, homem ligado a Pombal, nas suas Instruções Políticas, coloca a transferência da corte como solução para a decadência econômica lusitana. "Problemas que em duas palavras resolvo, dizendo que o dito príncipe, para poder conservar Portugal, necessita totalmente das riquezas do Brasil, e de nenhuma maneira das de Portugal, que não tem, para sustentar o Brasil; de que se segue, que é mais cômodo e mais seguro estar onde se tem o que sobeja, que onde se espera o de que se carece" ${ }^{\circ 1}$.

Com o trecho acima fica claro que para estes homens públicos, influenciados por uma atitude ilustrada cética em relação à algumas atitudes tradicionais políticas e pela análise empírica dos acontecimentos, a sociedade lusitana deveria se adequar às premissas da modernidade e que para a sobrevivência do Estado absolutista em Portugal, este deveria buscar soluções pouco ortodoxas (podemos colocar como exemplo o afastamento de D.Rodrigo de Sousa Coutinho em 1803 da esfera política por causa da fraca aceitação da sua reforma das finanças públicas, que feria, frontalmente os interesses particulares de uma nobreza portuguesa tradicionalmente ligada à terra e nem

\footnotetext{
${ }^{60}$ SILVA, Ana Rosa Cloclet. Op.cit. p.52. A autora, em relação às soluções econômicas para o Reino, aponta que essas idéias econômicas liberais não eram facilmente aceitas pelos ilustrados portugueses, com a exceção de Ribeiro Sanches e D.Luís da Cunha, que presos ainda a um pensamento tradicional, "professavam idéias tipicamente mercantilistas".

${ }^{61}$ CUNHA, D.Luís da Cunha. Instruções Políticas. Lisboa: Comissão Nacional para as Comemorações dos Descobrimentos Portugueses, 2001, p.371.
} 
um pouco interessada nas melhores soluções para a crise do Estado português, ou seja, uma nobreza avessa às questões públicas).

Lentamente na conjuntura política, econômica e cultural portuguesa estruturou-se uma nova visão de mundo comprometida com os "avanços" ilustrados europeus, que passando pela experiência dos "estrangeirados" iria culminar seu processo com a política pombalina. Período de formação caracterizado por uma ampla mentalidade antijesuítica, símbolo de um desejo de secularização dos meios culturais, e por uma busca para superar a "defasagem" estrutural de Portugal em relação às outras nações da Europa.

“Antiescolasticismo, antijesuitismo, não representam senão uma transformação bem mais profunda então em marcha: a secularização política, o racionalismo imanentista no plano filosófico, o individualismo em todos os níveis do real",62.

O principal ministro de José I (1750 - 1777), Sebastião José de Carvalho e Melo, o marquês de Pombal, colocou como projetos norteadores de sua administração a concentração do poder nas mãos do Estado absolutista português e a "urgência em se criar um aparato humano e institucional eficiente na execução de reformas ilustradas encaminhadas pelo poder, impondo assim, a definição dos novos critérios que passariam a orientar a formação do homem público luso-brasileiro"63. O grande objetivo de Pombal: repensar o império na sua totalidade ${ }^{64}$, melhorando as condições materiais e intelectuais do Reino e das Colônias, exemplarmente, o Brasil, passava necessariamente, por uma reforma pedagógica, que tinha como objetivo último, a formação de um novo homem público, intelectualmente capaz de conduzir os interesses políticos e econômicos de Portugal na Europa e preservar os vastos domínios ultramarinos do Império, verdadeiro trunfo político de Portugal no jogo de forças dos interesses europeus.

A questão pedagógica, assim como no caso da Ilustração portuguesa, esteve presente nas preocupações centrais dos filósofos das Luzes, que partilharam, em massa, dos ideais que fomentaram a Enciclopédia: o esclarecimento da sociedade visando o impulso ao progresso ${ }^{65}$. Cabe destacar que o ideal pedagógico do Iluminismo, que

\footnotetext{
${ }^{62}$ FALCON, Francisco José Calazans. Op.cit. p. 342.

${ }^{63}$ SILVA, Ana Rosa Cloclet da. Inventando a Nação - Intelectuais Ilustrados e Estadistas LusoBrasileiros na Crise do Antigo Regime Português (1750 - 1822). São Paulo: Hucitec, 2006, p.23.

${ }^{64}$ Idem, p. 23.

65 "Sobrepairando a tudo, triunfante, síntese de todas as grandes esperanças, mediação eficaz entre a teoria e a prática, a educação é o valor instrumental supremo; panacéia só ela capaz de abrir caminho à elevação da plebe, essa plebe que representa afinal a negação do espírito ilustrado, mas ao mesmo
} 
apesar de contar com grupos sociais não específicos (clero, nobres e elementos de setores sociais inferiores), estava comprometido com a esfera do poder, logo endossando a desigualdade social existente, a grande exceção, diante deste pensamento, talvez seja Rousseau. "Se o conceito de liberdade revelou oscilações - oriundas das tensões que permearam a convivência entre direito natural e antigo, entre liberdade e liberdades, indivíduo abstrato e ser social - a igualdade raramente ultrapassou o plano político" ${ }^{\circ 6}$.

A experiência intelectual iluminista portuguesa, formada nos quadros do Reformismo estatal engendrado por Pombal a partir da visão dos estrangeirados, pouco, ou nada fez, em relação às liberdades políticas individuais e coletivas, concentrando seu aparato reflexivo nas questões econômicas que diziam respeito ao Império. Esta visão utilitarista do conhecimento pode ser verificado no quadro formativo de homens públicos (o novo modelo de estadista) da Universidade de Coimbra durante o governo de Pombal.

Seguindo as instruções dos estrangeirados, Sebastião José de Carvalho e Melo, que também passou pela experiência do "estrangeiramento" ( ficou um período na Corte de Londres e Viena em missão diplomática), arquitetou toda a administração portuguesa com base nestas questões pedagógicas/reformistas ilustradas. Como ficou exemplificado no repúdio do Marquês à prejudicial aliança anglo-lusitana, representada pelo unilateral Tratado de Methuen (1703); na incapacidade de Portugal tirar reais vantagens, voltadas para um espírito empreendedor próprio do nascente capitalismo industrial, da exploração das minas de ouro na América portuguesa; no afastamento dos jesuítas e outros clérigos do ensino público - no alvará de 28 de junho de 1759 - (que mesmo assim, não foi o bastante para afastar traços de continuidade do tradicional pensamento eclesiástico nas instituições de ensino) e nas reformas do ensino superior (principalmente na Universidade de Coimbra) ${ }^{67}$, destinadas à elite social e formadora do futuro quadro de estadistas de finais dos setecentos, com base nas idéias ilustradas que circulavam na Europa.

A questão pedagógica, alvo de constantes reformas ligadas ao ensino e à relação com o conhecimento, representa o ponto central do debate de idéias dos dois momentos

tempo a perspectiva de superação dessa mesma negação”. FALCON, Francisco José Calazans. Op.cit. p.98.

${ }^{66}$ SILVA,Ana Rosa Cloclet. Op.cit. p. 32.

${ }^{67}$ Cabe destacar os estabelecimentos anexos à Universidade de Coimbra como, o Jardim Botânico, o Laboratório Químico e o Museu Nacional, que confirmam a preocupação com a experimentação e a praticidade do ensino. 
políticos, o consulado pombalino e o governo mariano, que marcaram o redirecionamento estatal de um antigo sistema colonial, para um mais próximo às questões intelectuais do contexto cultural europeu. $\mathrm{O}$ ensino, tanto para a administração pombalina quanto para os objetivos políticos marianos, foi uma "peça fundamental da promoção da pública prosperidade - e da conseqüente superação dos obstáculos ao "progresso" do Reino -, refletindo um projeto mais amplo que unia saber, poder e transformação das estruturas vigentes." 68 .

Assim como as idéias dos ilustrados lusitanos pertencentes aos dois períodos políticos mencionados da história portuguesa funcionaram pelo binômio da continuidade e da ruptura, o Reformismo estatal guiou-se pelo mesmo padrão normativo, afinal de contas, "o estadista português não deixou de conceber a importância de se preservar mecanismos tradicionais de afirmação da soberania nacional, inseridos numa lógica própria ao Antigo Regime (...)”69.

Apesar do cuidado em se preservar a soberania nacional (baseada em princípios normativos do Antigo Regime que se afastavam de qualquer abertura liberal política) e as estruturas do mercantilismo econômico, o Reformismo estatal e a política defendida pelos estadistas luso-brasileiros mostraram que o exercício da vida pública deveria estar desvinculado da idéia de privilégio de nascimento, mas sim pela capacidade intelectual do estadista em questão. Assim o Estado Absolutista passou a depender da formação e da experiência em outros contextos políticos de seus estadistas, confirmando a questão pedagógica como elo fundamental para a compreensão da política realizada na época.

As idéias dos estadistas luso-brasileiros do governo de Maria I, iniciado em 1777, seguem, em suas questões centrais referentes à posição do intelectual perante o conhecimento, a mentalidade ilustrada do período pombalino. Não esquecendo, de forma alguma, que estes estadistas deviam a sua existência ao projeto reformador/pedagógico iniciado no consulado de Pombal.

O governo de D.Maria I e do Príncipe Regente Dom João segue, numa relação de continuidade crítica que promove, igualmente, rupturas com o modelo político anterior, "o desdobramento do processo de reformas"70 dos estadistas luso-brasileiros, aprofundando o Reformismo político baseado nas Luzes do consulado pombalino.

\footnotetext{
${ }^{68}$ SILVA, Ana Rosa Cloclet. Op.cit. p.59.

${ }^{69}$ Idem, p.57.

${ }^{70}$ NOVAIS, Fernando. Portugal e Brasil na Crise do Antigo Sistema Colonial (1777-1808). São Paulo: Hucitec, 2001, p.224.
} 
Ideologicamente estes estadistas (ou intelectuais ilustrados) se concentraram sob a égide da Academia de Ciências de Lisboa, fundada em dezembro de 1779, e que representou a "principal herança da Ilustração portuguesa inaugurada por Pombal seu pragmatismo cientificista - agora aprofundada e alçada a um grau máximo de validação política"71. Com esta constatação podemos afirmar que o teor da reforma pedagógica iniciada no governo do principal ministro de José I continuou balizada nas mesmas premissas do conhecimento empírico, distendido em todas as suas potencialidades de aplicação política, já que o caminho para este "novo homem público", imbuído da mentalidade das Luzes e voltado para uma efetiva participação administrativa, havia sido aberto por Portugal.

O conhecimento do período, além de servir como base para uma quase certa atuação na esfera administrativa do Estado português, daquele que o dominasse, tinha o objetivo de formar indivíduos moralmente condizentes com o poder estatal como no caso da família Sousa Coutinho, culta e partidária do regime absolutista português.

Confirmando esta visão utilitarista do conhecimento podemos destacar o papel político desempenhado pelas Sociedades Econômicas, que faziam um mapeamento das potencialidades econômicas das regiões do Reino e do Império, compactuando com uma nascente mentalidade capitalista industrial, dominadora das políticas estatais da Europa do período, que aliava a investigação científica e sua posterior aplicação como medidas propagadoras do progresso.

As soluções para os problemas sociais e econômicos enfrentados por Portugal requeriam propostas inovadoras e ao mesmo tempo aliadas a uma lógica mercantilista, já que o comércio constituía o ponto nevrálgico da economia lusitana e era este que estava sofrendo com a posição desvantajosa de Portugal na concorrência dos mercados internacionais.

Autores como Fernando Novais e Ana Rosa Cloclet da Silva apontam o período de intensificação de substanciosas mudanças econômicas em Portugal, desencadeadas, de maneira mais concreta, nos governos mariano e joanino, como um momento de crise do antigo sistema colonial. Crise apontada como fruto de uma nova configuração econômica e política no contexto internacional, marcado pela disputa de mercados consumidores devido ao avanço econômico dos países industrializados, comportamento

\footnotetext{
${ }^{71}$ SILVA, Ana Rosa Cloclet. Op.cit.p. 109.
} 
guiado pelas idéias do liberalismo econômico, e pelo desmonte das estruturas do Antigo Regime, efeito constantemente renovado por diversas idéias políticas liberais.

Como medidas para resolver os impasses vividos por Portugal foi proposta uma análise empírica sobre os problemas do Reino, historicamente fundamentados, e deste modo, proporcionando um tratamento privilegiado dos estudos da História que visavam um maior comprometimento com a tradição nacional e com uma possível superação dos erros advindos do passado. A produção intelectual das Memórias, colocava como necessário o "recuo temporal da análise, necessário à identificação das causas e soluções apropriadas ao problema diagnosticado explicando a importância conferida ao conhecimento do passado nacional ${ }^{, 72}$.

Cabe destacar a forte presença da temática agrária na produção da Academia, tema corrente dos debates econômicos na Europa do período que valorizaram a produção dos insumos como fonte de riqueza para o Estado. O reconhecimento da agricultura pelos acadêmicos e estadistas luso-brasileiros advém da observação da realidade portuguesa, que tratava a produção dos gêneros da terra com desdém, e cheia de resquícios feudais, como a opressão dos lavradores, o desprezo de seus privilégios e a má utilização dos solos. Para os acadêmicos, a decadência da agricultura era um ponto importante a ser combatido para livrar o país de seu atraso econômico.

O destaque dado para a agricultura pelos estadistas luso-brasileiros revelou mudanças para a política mercantilista estatal, que não deveria mais dar tanta importância à idéia de balança comercial favorável mais sim, a sua estrutura produtiva $^{73}$.

Inspirados pelas teses liberais de circulação e da concorrência, os acadêmicos, em suas Memórias, chamaram a atenção para um problema relacionado à falta de integração do território do Reino, a falta de um mercado nacional, que seria dinamizado com uma política de incentivo à circulação de produtos e mercadorias nas diferentes regiões de Portugal.

Para concluir, o papel desempenhado por estes acadêmicos e estadistas foi a de instrumentalizar as teorias econômicas do contexto internacional da época de acordo com a observação da realidade lusitana e dos limites proporcionados pelo Estado absolutista português. Para libertar Portugal de sua notória decadência econômica foram

\footnotetext{
${ }^{72}$ SILVA, Ana Rosa Cloclet da. Op.cit.p. 126.

73 “Na realidade, porém, o pensamento fisiocrático era mobilizado para servir a uma política econômica reformista” NOVAIS, Fernando A. Op.cit. p. 228.
} 
criadas condições para que fossem aproveitadas as potencialidades da terra lusitana e, sobretudo, do riquíssimo mundo ultramarino.

Além de repensar a prática mercantilista e as velhas estruturas de poder administrativo, a ilustração portuguesa, inevitavelmente, anuncia uma nova época de reflexão ${ }^{74}$ calcada num momento histórico paradigmático, o período "romântico" e liberal, fruto da "dupla revolução" (termo histórico criado por Hobsbawm para definir a "zona de impacto e influência" gerada pelas Revoluções Industrial e Francesa).

Como afirma Francisco Falcon: “(...) estamos convencidos de que o período pombalino solda-se historicamente não com aquilo que o precede, mas com o que vem depois. A se querer incluí-lo em algo mais vasto, é muito mais lógico considerá-lo de uma perspectiva que culmina na Revolução Liberal de 1820. Não que ele tenha sido liberal ou "precursor" do liberalismo, como quiseram seus admiradores do século XIX. Mas exatamente porque sua prática política e ideológica abre novos caminhos, coloca novos problemas, além de alguns antigos, sem dúvida, mas em novas perspectivas"

\subsection{A experiência liberal - o contexto político de Herculano:}

Assim como foram mostradas as continuidades teóricas entre Ilustração e Romantismo, de uma maneira geral, no início do proposto capítulo, torna-se necessário traçar alguns vínculos entre os projetos pensados pelos estadistas e acadêmicos lusobrasileiros para a renovação econômica e cultural de Portugal com as propostas de Garrett e Herculano de melhoria da nação portuguesa.

Dentre os acontecimentos históricos ocorridos no início do século XIX, talvez a transferência da família real portuguesa para o Brasil, em 1808, seja o que provocou um maior impacto dentro da sociedade portuguesa. A partir deste episódio, e especialmente com seus futuros desdobramentos, como a elevação do Brasil à categoria de Reino Unido a Portugal e Algarves, em $1815^{76}$, os projetos políticos das esferas sociais que

\footnotetext{
74 “(...) a agonia do absolutismo, entre nós, se apresentou extremamente longa-pelas mesmas razões é possível remontar muito longe na busca das raízes nacionais da ideologia liberal.

O seu alento inicial reside em certos aspectos do pensamento iluminista, essas "luzes" que se foram acendendo por cá no último quartel do século XVIII (...)”. SERRÃO, Joel. Do Sebastianismo ao Socialismo em Portugal. Lisboa: Livros Horizonte, 1973, p.43.

${ }^{75}$ FALCON, Francisco José Calazans. Op.cit. p.225.

76 “A situação (grave crise econômica decorrente, principalmente, da abertura dos portos coloniais) pôde ser mascarada até 1815, enquanto as guerras européias justificavam a aliança com a Inglaterra e a transferência da Corte. Aceitava-se, inclusive, a administração do reino pelo general Beresford, sob o
} 
detinham o poder político e econômico, tanto de Portugal quanto do Brasil, vão categoricamente, se distanciar.

Em Portugal, vai surgindo, gradualmente, um nítido descontentamento por parte da nobreza e da burguesia comercial (ávidas por uma maior participação política e pela volta do status colonial do Brasil) em relação à política dos estadistas da corte brasileira de D.João VI, que a cada nova medida deixavam transparecer a preferência pelo Brasil nas decisões relacionadas à preservação do Império e na opção pela continuidade da corte joanina na América portuguesa ${ }^{77}$. Este descontentamento culminou na Revolução Constitucionalista do Porto de 1820. “A revolução era fruto da situação opressiva em que Portugal vivia, desprovido da presença de seu soberano desde 1807. O anseio de mudanças e a crença nas reformas, de que as cortes, a Constituição e a liberdade seriam portadoras, demonstravam que a revolução era uma "consequência necessária”, pois esses estado de coisas não podia mais persistir"78.

A Revolução de 1820 e a subseqüente, Constituição de 1822, representaram o elo de ligação entre o desgastado "Antigo Regime" português, que ainda tentou se manter a partir de um programa reformista "esclarecido" ilustrado, e a experiência liberal portuguesa do século XIX.

A questão pedagógica, a formação do quadro administrativo português, a definição de um plano econômico para Portugal, balizado sobre o comércio, interno e colonial, e a agricultura, enfim, a proposta liberal de reformular novos significados e sentidos para as

argumento de que comandava o exército quando o invasor francês foi expulso de Portugal. Procuravase, ainda, fazer prevalecer a idéia de que a aliança com a Inglaterra era a forma possível para a inserção portuguesa nas relações políticas do Continente.

Após a derrota de Napoleão e a reordenação feita através do Congresso de Viena, porém, ficou evidente a intenção do Regente (continuar administrando o Império no Brasil). Pode-se dizer que, só a partir de então, os descontentamentos tornaram-se incontroláveis e a união dos dois domínios da monarquia lusa passou a ter os seus dias contados”. BERBEL, Márcia Regina. Deputados do Brasil nas Cortes Portuguesas de 1821-1822: Um Estudo sobre o conceito de Nação. Dissertação de Doutorado apresentada ao Departamento de História da FFLCH/USP, São Paulo, 1997, pp.31 e 32. ${ }^{77}$ SOUZA, Iara Lins Carvalho. Pátria Coroada - O Brasil como corpo político autônomo - 17801831. São Paulo: Editora Unesp, 1999. No trecho selecionado a autora mostra os dois grandes perigos para a sociedade portuguesa enumerados pelas Cortes Constituintes $(1821-1822)$, o anarquismo e o despotismo. Sendo que o despotismo é colocado da seguinte maneira: “(...) o despotismo, entendido como a concentração descabida de poder numa figura ou instituição e do qual a maior evidência, naquele momento, residia na atuação dos ministros no Rio de Janeiro, que enganavam o rei com lisonjas, pois D.João continuava sendo justo e bom, apesar de tão enganado" p.85. Aqui fica evidenciado que o grande problema da política joanina, para os vintistas, eram as propostas dos estadistas luso-brasileiros do Rio de Janeiro e não a figura real de D.João VI.

${ }^{78}$ NEVES, Lúcia Maria Bastos Pereira das Neves e FERREIRA, Tânia Maria Tavares Bessone da Cruz. “O cidadão Almeida Garrett e o 24 de agosto de 1821”. In: NEVES, Lúcia Maria Bastos Pereira das Neves, OLIVEIRA, Paulo Mota, DAVID, Sérgio Nazar e FERREIRA, Tânia Maria Tavares Bessone da Cruz. (Orgs.). Literatura, história e política em Portugal (1820-1856). Rio de Janeiro: Editora UERJ, 2007, p.18. 
práticas políticas, sociais e econômicas lusitanas, herdou, indubitavelmente, as idéias e atitudes do pensamento ilustrado, adicionando por conseguinte, concepções e atitudes de uma visão de mundo "pós-Revolução Francesa"79.

A Revolução de 1820, pensada como processo histórico ligado diretamente ao pensamento ilustrado português ${ }^{80}$, como bem configurou Francisco Falcon, e ao campo de influência da "dupla revolução", pode ser classificada como evento de mudanças estruturais burguesas.

A historiadora Márcia Regina Berbel ao analisar a historiografia da Revolução de 1820 chama a atenção para dois autores que encararam essa proposta como norteadora do processo revolucionário português: Julião Soares de Azevedo e Fernando Piteira Santos. De acordo com a autora, a obra de ambos trabalha a Revolução de 20: "Como episódios de uma revolução burguesa, os acontecimentos que marcaram os anos de 1820 a 1822 expressariam a busca pela união da sociedade lusitana sob a égide da burguesia" $^{, 81}$.

Para Fernando Piteira Santos a Revolução de 1820 é eminentemente burguesa porque: "Todos os privilégios ou condições particulares que impeçam a circulação das mercadorias ou, afastem o burguês da direção dos negócios públicos serão objeto da sua hostilidade. É a luta pela liberdade econômica, pelo poder político, pela afirmação social da classe burguesa" 82 .

A crítica de Márcia Regina Berbel em relação à linha interpretativa representada por Soares de Azevedo e Piteira Santos ressalta a ausência do "amálgama de classes" presente no Portugal do período $^{83}$, reveladora da diversidade social do processo

\footnotetext{
79 “Os projetos vintistas, porém, entre outras coisas, pensavam na uniformização administrativa e na escolarização em massa, ampliaram a atuação da imprensa, modificaram a língua portuguesa. Como projetos liberais e nacionalistas, pretendiam se integrar nos novos tempos" BERBEL, Márcia Regina. Deputados do Brasil nas Cortes Portuguesas de 1821-1822: Um Estudo sobre o conceito de Nação. Dissertação de Doutorado apresentada ao Departamento de História da FFLCH/USP, São Paulo, 1997, p. 7.

${ }^{80}$ Mesmo com os limites da Ilustração na sua visão de mundo "elitista" e "aristocrática", no tocante ao pensamento dos "estrangeirados" nota-se que "(...) em vários outros passos,observa-se a preocupação em exaltar os valores de uma sociedade burguesa que crê em ascensão: a produção, o trabalho, o comércio; daí a especialização de funções, a exigência de um ensino adaptado, a tais imposições do Estado Civil e Político”. FALCON, Francisco José Calazans. Op.cit. p. 354.

${ }^{81}$ BERBEL, Márcia Regina. Op.cit. p. 17.

${ }^{82}$ SANTOS, Fernando Piteira. Geografia e Economia da Revolução de 1820. Lisboa: Publicações Europa América, s/d, p.38.

83 “Há erro manifesto quando se escreve que o pronunciamento de 24 de Agosto de 1820 e as manifestações subsequentes em todo o País foram uma revolução liberal da burguesia. Na realidade, foram apenas a expressão de uma coalizão de descontentamentos generalizados aos diversos núcleos sociais da população. Nas cúpulas portuenses que dirigiram o pronunciamento de 24 de Agosto, os fidalgos formavam lado a lado com os burgueses, as profissões liberais com o alto funcionalismo, a esquerda com a direita.” DIAS, J. S. da Silva. “A revolução liberal portuguesa: amálgama e não
} 
revolucionário, e a ausência de um estudo mais elaborado sobre os deputados brasileiros nas Cortes Constituintes, com propostas divergentes da defendida pela "burguesia" portuguesa.

Assim, antes de prosseguirmos nossas considerações sobre a Revolução de 1820 e o desdobramento do contexto histórico liberal português, é de suma importância enfatizar a complexidade desses acontecimentos em Portugal e da miríade de interpretações históricas sobre o conjunto político, econômico, social e cultural português do século XIX. Para o presente estudo cabe somente apresentar alguns dados relevantes para um maior esclarecimento das idéias de Alexandre Herculano e do primeiro momento do Romantismo português.

Sobre a Revolução de 1820 é interessante mostrar a participação do "Sinédrio", 84 , movimento composto por membros ligados com os interesses comerciais da cidade do Porto, importante para a articulação do movimento do dia 24 de Agosto de $1820^{85}$.

“Os integrantes do Sinédrio estavam fortemente influenciados pelo liberalismo espanhol e se tornaram bem mais agressivos depois da vitória da revolução na Espanha entre janeiro e março de 1820",86. Esse movimento ou "sociedade secreta" além de ter como expressões de ordem o sentimento de abandono político por parte da administração portuguesa, de renovação econômica e de afastamento da interferência inglesa dos assuntos internos de Portugal, tinham como ponto de referência a Espanha Liberal, revelando a herança ilustrada de se manter um diálogo com os novos tempos europeus.

substituição de classes" In: FERREIRA, Maria de Fátima Sá e Melo; PEREIRA, Miriam Halpern \& SERRA, João B. O Liberalismo na Península Ibérica na primeira metade do século XIX (Comunicações ao Colóquio organizado pelo Centro de Estudos de História Contemporânea Portuguesa, 1981) - $1^{\circ}$ Volume, Portugal: Sá da Costa Editora, s/d, p.21.

${ }^{84}$ Movimento também chamado por Victor Sá de "comitê clandestino". SÁ, Victor de. Instauração do Liberalismo em Portugal. Portugal: Livros Horizonte, 1987, p.11. Expressão que, imediatamente, nos faz lembrar das sociedades maçônicas e das sociedades secretas revolucionárias da conjuntura histórica européia, importantes como locais de amadurecimento político e de forte expressão de uma mentalidade romântica. "Nos anos que, na Europa, vão de 1815 a 1848, as sociedades secretas constituem um fenômeno internacional: difundem-se em França e nos Estados italianos,na Rússia e nos Estados alemães, na Áustria e na Polónia. (...). Os anos em torno de 1820 são marcados, em França e em Itália, pelas actividades da Carbonária (...)” BACZKO, Bronislaw. Capítulo VIII - “O Revolucionário”. In: FURET, François (Direção). O Homem Romântico. Lisboa: Editorial Presença, Coleção: “O Homem e a História" - vol.9, 1999, p.238.

85 “Na verdade, a relativa precariedade da classe burguesa e a situação social do País, (...),condenavam os militares a serem o fiel da balança nas situações revolucionárias que se avizinhavam. Por isso, à guarnição militar do Porto, doutrinada pelo Sinédrio (1818), caberá a tarefa de, em 24 de Agosto de 1820, desembainhar as suas espadas para proclamar extinto o regime absolutista e abrir as vias à regeneração da Pátria, humilhada e desmembrada”. SERRÃO, Joel. Op.cit. p. 47.

${ }^{86}$ BERBEL, Márcia. Op.cit. p.36. 
Com o início do processo revolucionário liberal em Portugal, algumas medidas políticas tornam-se claras, como a preservação da ordem social (reflexo do famoso "Período do Terror" na França), a manutenção de uma divisão social por classes, a confiança na figura do monarca, o combate ao absolutismo e a representatividade política burguesa. Medidas políticas dependentes de uma nova ordem social comandada pelos ideais máximos da burguesia: livre concorrência, propriedade, segurança e liberdade política e econômica.

O processo revolucionário iniciado no Porto, ganha sublevações populares, na província de Entre Douro e Minho, mas somente quando o movimento revolucionário chega a Lisboa, que está consumada a Regeneração ${ }^{87}$.

No bojo dessas considerações, vale lembrar que para firmar a idéia de Regeneração, a Junta Provisional do Governo Supremo do Reino, primeiro governo liberal estruturado no Porto, fazia questão de lembrar o episódio de 1807 e defender uma "clara intenção de conciliar os valores tradicionais da cidade com os setores sociais mais dinâmicos envolvidos no processo revolucionário e com as regiões mais lesadas durante a crise ${ }^{, 88}$.

Depois de consolidado um governo liberal no Porto e do alastramento do movimento revolucionário, a cidade de Lisboa vê a necessidade de se aliar politicamente com Porto, esquecendo todas as diferenças. "O encontro dos governos de Lisboa e Porto foi cuidadosamente acertado entre representantes das duas Juntas, que trataram de conciliar os diversos grupos envolvidos e evitar manifestações mais intensas. Foi formalizado no acordo de 27 de setembro de 1820, que constituiu o novo governo de Portugal com cinco elementos do antigo Executivo de Lisboa e onze do governo do Porto" ${ }^{, 89}$. Foi sob os auspícios dos principais centros políticos e econômicos de Portugal que o caminho constitucional se consolidou com as eleições dos deputados das Cortes Constituintes (instauradas em 26 de janeiro de 1821).

Com a administração do Congresso das Cortes, cada vez mais a idéia de Regeneração do movimento liberal ganha força. Revelando a não resolvida questão da "decadência" cultural de Portugal que circulava os meios intelectuais desde o período da

\footnotetext{
${ }^{87}$ Sobre a idéia de "Regeneração" é importante enfatizar uma preocupação de todo o movimento liberal português de dialogar com o passado português, ou seja, ter um discurso político historicamente fundamentado. "É igualmente preocupação dominante dos revolucionários de 1820 entroncar numa tradição remota, e enraizadamente portuguesa, os objetivos constitucionais do movimento. (...)” SANTOS, Fernando Piteira. Op.cit. p.151 (Nota B).

${ }^{88}$ BERBEL, Márcia Regina. Op.cit. p. 37.

${ }^{89}$ Idem, p.38.
} 
Ilustração. "Portanto, o trabalho do Congresso era de "regeneração" da monarquia e dos direitos tradicionais da nação portuguesa, os quais, estipulados desde a formação do Reino, haviam sido desvirtuados pelo absolutismo, em nome da "idéia sacrílega" do poder divino dos reis. O "soberano Congresso" aparecia, nesse discurso, como legítimo herdeiro das antigas Cortes (o famoso episódio das "Cortes de Lamego" que coroaram D.Afonso Henriques como primeiro Rei de Portugal). A proposta de Constituição era a afirmação dos direitos tradicionais e não uma transcrição dos publicistas modernos" $"$.

A Constituição de 1822, objetivo primordial da Revolução, foi o documento que garantiu a legitimidade representativa burguesa e de suas principais reivindicações ${ }^{91}$. A forma de governo definida seria a monarquia constitucional hereditária e o poder ficaria dividido em Executivo, Legislativo e Judiciário, respeitando o princípio "ilustrado" de Locke e Montesquieu do "equilíbrio dos poderes".

“A burguesia comercial representa, neste momento histórico, na contradição da velha ordem e na afirmação da ordem nova, a consciência progressiva da Nação: o burguês (liberal, capitalista) é o elemento dinâmico e criador; a burguesia é a força social intérprete, nas condições históricas do início do século XIX, de uma consciência nacional, econômica, social e política: sente-se a Nação, quer ser o Estado" ${ }^{92}$.

Com as principais medidas da Constituição de 1822, negligenciando, é claro, os "intervalos históricos" absolutistas de D.Miguel, podemos afirmar que toda a experiência política portuguesa posterior teve que dialogar com esse primeiro documento liberal do século $\mathrm{XIX}^{93}$. Consolidando algumas propostas, como fez Mouzinho da Silveira, em relação à distribuição das terras nobiliárquicas, ou as combatendo, como a ditadura de Costa Cabral, em relação às liberdades civis.

A Revolução do Porto inaugurou um conturbado cenário político para a primeira metade do século XIX em Portugal, de rupturas ou continuidades com as propostas liberais, marcada pelas lutas entre setores sociais politicamente tradicionais, como os

\footnotetext{
${ }^{90}$ BERBEL, Márcia Regina. Op.cit. p.41.

91 "O texto foi estruturado em 36 artigos distribuídos em duas partes. A primeira começava por garantir a defesa da liberdade, segurança e propriedade de todo cidadão”. Idem, p.44.

${ }^{92}$ SANTOS, Fernando Piteira. Op.cit. p.124.

93 “Ora, para além de pormenores atinentes à esfera do direito constitucional, parece legítimo concluirse dessas bases - não só da Constituição de 1822, mas, directa ou indirectamente, de todas as que se lhe sucederam - as traves mestras do liberalismo português, a saber: por um lado, o direito à propriedade individual, no qual assentavam as liberdades do cidadão, (...), e, por outro, o reconhecimento da nação portuguesa como "a união de todos os portugueses de ambos os hemisférios”, . SERRÃO, Joel. Op.cit. p.58.
} 
miguelistas (absolutistas) com grupos voltados a um pensamento liberal e, posteriormente, por disputas entre os próprios representantes de uma proposta política e econômica liberal para a nação, como os setembristas e os cartistas.

"Podemos distinguir diferentes momentos no processo da instauração do liberalismo em Portugal: um primeiro período liberal (1820- 23) dominado pelas Cortes que decretaram as primeiras reformas e votaram uma Constituição; uma reacção absolutista (1823-26) que aboliu a Constituição e anulou as reformas; um segundo período liberal (1826-28), a seguir à morte do rei D.João VI, durante o qual se adoptou a Carta outorgada aos Portugueses pelo príncipe Pedro, imperador do Brasil e herdeiro do trono de Portugal; uma nova reacção absolutista (1828-1834) que se desencadeou logo após o desembarque do infante Miguel, em Lisboa; enfim a guerra civil (1832-34) que terminou com a vitória definitiva dos liberias adeptos da Carta outorgada por Pedro em 1826" 94 .

Tanto Garrett (1799-1854) quanto Herculano (1810-1877), influenciados pelas idéias do Romantismo, participaram ativamente da guerra civil, de 1831, em Portugal e das tropas de D.Pedro, duque de Bragança (título usado por D.Pedro I do Brasil que havia abdicado do trono português passando a regência para seu irmão D.Miguel até que a rainha, Maria da Glória, sua filha, pudesse exercer efetivamente o poder), que saiu dos Açores e desembarcou em Portugal, em julho de 1832, com a intenção de afastar o governo absolutista de D.Miguel. Outro levante revolucionário que ambos participaram, mas de lados opostos ${ }^{95}$, foi a Revolução de Setembro, de 1836, conflito que levou a rainha D.Maria II, filha de D.Pedro, a revogar a Carta Constitucional de D.Pedro, criada em 1826, e a restabelecer a Constituição de 1822.

A Carta Constitucional outorgada por D.Pedro de Bragança tinha como objetivo tornar o regime liberal mais moderado em suas formas representativas e garantir o estabelecimento de um forte Poder Executivo, onde o Rei teria poderes superiores ao do Poder Legislativo, representado pela Câmara dos deputados ${ }^{96}$.

\footnotetext{
${ }_{95}^{94}$ SÁ, Victor de. Op.cit. p.10.

${ }^{95}$ Almeida Garrett era próximo das lideranças setembristas, principalmente de Passos Manuel, já Alexandre Herculano era defensor da Carta Constitucional imposta por D.Pedro, duque de Bragança, em 1828.

96 "A Carta Constitucional que o príncipe Pedro acabava de outorgar em 1826 não ia ser, de resto, um instrumento favorável à democracia. (...). Adoptando o bicamaralismo (com sufrágio indireto e censitário para a câmara dos deputados, e nomeação real vitalícia e hereditária para a dos pares), o rei atribuía a si mesmo a qualidade de chefe do Poder Executivo, que seria exercido pelos seus ministros (Câmara dos Pares). Desta forma, o Governo não era responsável perante o parlamento, mas perante o próprio rei”. SÁ, Victor de. Op.cit. p.29.
} 
Seguindo o modelo da Constituição de 1824, D.Pedro instaura no constitucionalismo português o princípio do Poder Moderador, que era de uso privativo do rei, tinha o poder de sancionar decretos do Legislativo e poderia dissolver a Câmara dos Deputados, ou seja, esse novo princípio presente na Carta serviria de ótimo instrumento para garantir um equilíbrio de poderes entre a "tradição" monárquica e os "novos tempos" constitucionais e liberais.

Para a Constituição de 1822 a soberania estava concentrada nas mãos da Nação ("união de todos os portugueses de ambos os hemisférios"), já para a Carta Constitucional de 1826 a soberania estava nas mãos do poder real. Ou seja, a outorga da Carta minimizou os possíveis avanços democráticos da Revolução de $1820^{97}$ e formalizou o conflito políticos entre liberais radicais e moderados.

“Juraram todos a Carta Constitucional e emigraram todos ou entraram nas cadeias do miguelismo, depois do fracasso da Belfastada. Todos se reconheceram, finalmente, como liberais e mostraram-se compenetrados, de que não haveria saída liberal para o País fora de um compromisso histórico. É a essencialidade e a vigência desse consenso que explica que a maioria dos liberais de 20 (...) se tivessem oposto ao setembrismo" 98 .

Tentando conciliar posições políticas divergentes em Portugal, D.Pedro de Bragança outorgou a Carta, abdicou do trono em favor de sua filha Maria da Glória e "perdoou" sua mãe D.Carlota Joaquina e D.Miguel pelo golpe absolutista, não bem sucedido, da "Vilafrancada". Trouxe, ainda, de volta da Áustria, o infante D.Miguel para ser regente do trono português até a maturidade de D.Maria da Glória99.

\footnotetext{
97 “Avançada e democrática, a Constituição de 1822 inseria princípios e práticas verdadeiramente revolucionários para o tempo, como a inviolabilidade do domicílio e da correspondência, a livre comunicação do pensamento não religioso sem dependência de censura prévia, a igualdade de todos perante a lei, a soberania indivisível e inalienável da Nação, a separação absoluta dos poderes, a relevância concedida às Cortes, o sufrágio directo e praticamente universal para os homens, etc. Poderia até ser considerada republicana. (...). (Já a Carta Constitucional de D.Pedro) "Era, essencialmente, uma concessão do poder absoluto do monarca aos seus súbditos portugueses, sem compromisso com qualquer soberania popular ou acto revolucionário emanado de "baixo", que obrigassem o soberano. Promovendo instituições de tipo liberal, nada tinha porém de democrático”. MARQUES, A.H. de Oliveira. "Cap.V - Organização administrativa e política" In: MARQUES, A.H. de. Oliveira \& SERRÃO, Joel. (direcção). Nova História de Portugal - Portugal e a Instauração do Liberalismo (volume IX). Lisboa: Editorial Presença, 2002 , p.240.

${ }^{98}$ DIAS, J.S. da Silva. Op.cit. p.22.

${ }^{99}$ Interessante é a visão de Garrett sobre o assunto: "Não contente de haver perdoado a seu indigno irmão, e para remover todo o pretexto de desassossego e perturbação em Portugal, D.Pedro lhe outorgou com a mão da jovem rainha todo o quinhão que razoàvelmente podia ceder na herança paterna - o título e dignidade real. Tanta generosidade devia confundir os inimigos mais assanhados: mas as gentes da facção apostólica não são homens com quem se transija, com quem se possa tratar de boa fé e com grandeza de alma: incapazes de os sentir e avaliar, não sabem nem podem corresponder a
} 
Aproveitando-se da divisão de tendências dentro do liberalismo português impostas pela outorga da Carta, D.Miguel foi agremiando apoio a sua causa de governar Portugal não como regente, mas como soberano. Começava um período de perseguições aos direitos políticos dos liberais e de censura. "Os absolutistas multiplicavam as aclamações e as referências a "D.Miguel I", "rei-absoluto", e os ataques à Maçonaria e aos Liberais em geral" 100 .

Com a nomeação de ministros fiéis a D.Miguel, Portugal passa a ser assolado por revoltas liberais contrárias ao absolutismo, que facilmente eram desbaratadas pelo apoio de tropas estrangeiras (espanhóis, na sua grande maioria) ao governo miguelista. Com a reunião das Cortes em Lisboa, no dia 23 de junho de 1828, o infante D.Miguel é proclamado Rei de Portugal.

"Se grande parte dos portugueses, com relevo para as massas rurais, o proletariado urbano e o clero nos seus estratos médios e inferiores, apoiou sem dúvida e com sinceridade D. Miguel e a restauração do absolutismo, outra grande parte, onde se contava muita da burguesia, da oficialidade militar, da burocracia, da Nobreza e, até, da sociedade eclesiástica, repeliu sem contemplações nem transigências o autoproclamado soberano" ${ }^{101}$.

Mesmo com o apoio inicial de muitas cortes européias, que tinham sido restauradas na conjuntura do Congresso de Viena e da Santa Aliança, o regime absolutista de D.Miguel não poderia impedir o avanço das idéias liberais ${ }^{102}$ e apagar a experiência da Revolução de 1820. O governo miguelista tentou resistir com perseguições, censuras, exílios e prisões, mas toda a Europa aclamava o fim das estruturas do Antigo Regime, exemplo disso ficou mais do que evidente, com a paradigmática Revolução de 1830, na França $^{103}$.

procedimentos generosos" GARRETT, Almeida. "Portugal na Balança da Europa". In: Obras de Almeida Garrett - volume I. Porto: Lello \& Irmão Editores, 1963, p. 867.

${ }^{100}$ MARQUES, A.H. de.Oliveira. "Capítulo XI - A Conjuntura". In: MARQUES, A.H. de.Oliveira \& SERRÃ̃, Joel. (direcção). Nova História de Portugal - Portugal e a Instauração do Liberalismo (volume IX). Lisboa: Editorial Presença, 2002, p. 573.

${ }^{101}$ Idem, p. 577.

102 "Não podia haver fé nem confiança no governo, nem segurança em nada; a incerteza e inconsistência do mesmo governo faria tudo incerto; os magistrados, receosos de se comprometer, não ousariam fazer sua obrigação; a autoridade pública perderia toda a força; e a revolução, quando fosse contida por meios artificiais, que nunca podem ser permanentes, a revolução iria fermentando e medrando em segredo, e romperia mais horrivel e espantosa". GARRETT, Almeida. Op.cit. p.896.

103 "Deu-se em Paris o Waterloo dos povos. Os dias 27,28 e 29 de Julho de 1830 decidiram a sorte da guerra: a civilização triunfante em Paris triunfará desde o Tejo ao Neva, e desde logo o lago Erié ao rio La Plata" Idem, p. 921. Não podemos esquecer que juntamente com as mudanças políticas, o movimento romântico, com sua sensibilidade e visão de mundo, estava envolvendo e ganhando novos adeptos nos meios cultos europeus e a burguesia lançava suas "amarras" econômicas pelo mundo afora. "Pela mesma 
“O entusiasmo, a excitação produzida por tão favoráveis acontecimentos, quais os da França dêsse tempo, tomavam todas as proporções e exprimiam-se nos tons mais vários. Desde as testemunhas presenciais da Revolução aos que, refugiados na Terceira, pareciam ter ouvido, coados pelas ondas, os ecos da fusilaria travada nas ruas de Paris, todos seguiam o vulto da Liberdade francesa como a uma dama em carne e osso" 104

O romântico e liberal Almeida Garrett, exilado constantemente, devido a sua atuação política, nos deixou um importante documento sobre o período de guerras liberais em Portugal, o "Portugal na Balança da Europa", obra de fins investigativos sobre a relação dos acontecimentos políticos em Portugal diante de um continente europeu em constante mudança, publicado em 1830.

Nessa obra, Garrett faz uma apologia pela causa liberal e pela Monarquia Constitucional e colocou como fora da ordem política, o governo absolutista. " $E$ todavia ainda é tempo para os reis, para alguns deles ao menos. Ainda podem abrir os olhos, e tomar a única resolução prudente e avisada que lhes resta, - lançar de si a oligarquia, desligar seus próprios interesses dos dela, vinculá-los com os do povo. $O$ povo não é inimigo dos reis; o povo europeu ama a monarquia" ${ }^{105}$.

Almeida Garrett e os demais românticos liberais só faziam coro ao momento de "ebulição" de idéias vividas pela Europa do período. Era um período de transição, o momento de crise, onde os valores deveriam se adequar à estruturação de um sistema capitalista industrial, burguês e liberal, mas, ao mesmo tempo, o instante perfeito para refletir sobre a realidade e lutar em prol de utopias coletivistas e nacionalistas.

Como escreveu o "combatente liberal" Almeida Garrett: "Prostar ou expulsar D.Miguel é fácil empresa; fácil a perfará a nação: mas equilibrar-se direitamente, estàvelmente na nova balança da Europa, é, em minha opinião, de tão complicadas e abstrusas dificuldades,(...). Não desanimemos porém; é antes árdua do que impossível a tarefa. Maior será a glória de Portugal: e em proporção de seu actual vilipêndio e

época (Revolução de 1830) intensificam-se na Inglaterra as lutas sociais emergentes do crescimento de um enorme proletariado, que reclama direitos políticos com o apoio da burguesia radical. O romance de Dickens, a poesia de Elisabeth Barret exprimem essas preocupações, ao mesmo tempo que o filósofo

John Stuart Mill prolonga o utilitarismo burguês, e Carlyle a metafísica do romantismo alemão, antecipando as tendências anti-racionalistas do fim do século, que vão abrindo caminho através do culto medievalista "pré-rafaelista" curiosamente unido por Ruskin e William Morris à crítica do capitalismo" SARAIVA, António José \& LOPES, Óscar. Op.cit. p.736.

${ }^{104}$ NEMÉSIO, Vitorino. A Mocidade de Herculano até a volta do exílio (1810-1832). Lisboa: Livraria Bertrand, Volume II, 1934, p. 173.

${ }^{105}$ GARRETT, Almeida. Op.cit. p. 922. 
desonra, crescerá a fama e renome dos Portugueses, quando de novo aparecem entre as nações da Terra, a nação que noutras eras foram, e que na nova era do mundo lhes compete ser" 106 .

Um espírito de otimismo e esperança numa Nação justa e gloriosa, que afastasse o "fantasma" da decadência cultural animava os românticos liberais, entre eles, Alexandre Herculano ${ }^{107}$. Todos eram contra o absolutismo e adoradores da "poderosa Liberdade", máxima aprendida no contexto da Revolução Francesa que possuía vários significados ${ }^{108}$ e dotada de um poderoso subjetivismo que deixava "enfurecido" os ânimos mais calmos.

Toda essa disposição ética burguesa, moral e crente na "liberdade" que fez com que o exército liberal capitaneado por D.Pedro nos Açores, obrigado a abdicar do trono brasileiro em 1831, fosse capaz de lutar contra D.Miguel e suas forças militares.

"O afamado exército miguelista, com os seus 80.000 homens, era um colosso com pés de barro, mantendo-se mais à base de acções individuais, de acomodatismos tradicionais e de actos repressivos, do que de entusiasmos colectivos conscientes. Em contraste, o exército liberal, embora escasso em número, caracterizava-se pelo voluntarismo da maioria dos seus participantes, pelo ideário sentido que os animava e pela qualidade dos quadros que o orientavam. Teve, além disso, à sua cabeça um chefe que era bravo e com eles frequentemente convivia: D.Pedro IV, o rei-soldado. A juventude mais válida e vanguardista alinhava, sem dúvida, com os Liberais, repelindo quer absolutismo quer Miguelismo"109.

O início dos combates começou em 10 de Julho de 1832 e foi até 23 de Maio de 1834, saindo vitoriosa da guerra civil o exército liberal de D.Pedro IV e sua Carta Constitucional. Com essa vitória, a burguesia assumiu definitivamente o poder político e econômico em Portugal $^{110}$ e tem de iniciar a formação de um quadro cultural

\footnotetext{
${ }^{106}$ Idem, p.924.

107 "Não foi por acaso que a Alexandre Herculano coube em quinhão o papel histórico do nosso mais lídimo romântico, qualquer seja o ângulo por que consideremos a sua obra e a sua personalidade." SERRÃO, Joel, Op.cit. p. 65.

108 "Por mais difícil que se apresente a tarefa de definição inequívoca de romantismo, aos olhos do historiador ele apresenta-se indissociavelmente cerzido ao processo contemporâneo do sinuoso curso da experiência burguesa da liberdade” Idem. p.64.

${ }^{109}$ MARQUES, A.H. de. Oliveira. "Capítulo XI - A Conjuntura”. In: MARQUES, A.H. de.Oliveira \& SERRÃO, Joel. (direcção). Nova História de Portugal - Portugal e a Instauração do Liberalismo (volume IX). Lisboa: Editorial Presença, 2002, p. 578.

110 “Na evolução da sociedade portuguesa, D.Pedro representou uma espécie de charneira entre o antigo regime senhorial e a era moderna do capitalismo. (...). Foi, pois, brandindo como estandarte a Carta outorgada por D.Pedro que os liberais empreenderam a luta armada para dar o assalto ao Poder. Após a vitória, a mesma Carta permitiu-lhes sentirem-se mais seguros da predominância da grande burguesia
} 
combatível com a visão de mundo burguesa ${ }^{111}$, para essa substanciosa tarefa, a reflexão pedagógica, os romances e os artigos jornalísticos de Almeida Garrett e Alexandre Herculano tiveram uma importância ímpar.

A visão de mundo burguesa clamava por mudanças significativas, proporcionadas pela Guerra Civil, que além de um plano cultural, eram reféns da garantia da propriedade e da liberdade política e econômica. Esse papel de "efetivador" dos valores burgueses coube ao conjunto de leis de Mouzinho da Silveira ${ }^{112}$.

Homem culto, leitor de Adam Smith e Kant, foi escolhido para livrar Portugal de sua "decadência econômica" e seu "atraso" em relação às modernas economias da Europa, numa típica missão "ilustrada".

Sobre as leis de Mouzinho da Silveira diz Oliveira Martins: “Dois princípios fundamentais servem de alicerce a esse notável corpo jurídico. É um a liberdade individual, concebida como um imperativo absoluto, inerente à natureza racional do homem, direito superior a qualquer outro, e inatacável, absolutamente soberano, em todas as suas manifestações jurídicas, intelectuais e econômicas. (...) É o outro fundamento a utilidade positiva, subordinando tudo à produção da riqueza com um critério prático materialista que deixava subalternizados todos os anteriores critérios distributivos, sem propriamente os negar"113.

Com os decretos de 1832 e 1834, Mouzinho da Silveira extinguiu os longevos direitos feudais, os "forais" e os dízimos. As leia atacaram os direitos de portagem, que recaíam sobre os produtos em circulação no País, facilitando o livre comércio e a circulação de mercadoria.

sobre as outras classes e camadas sociais, quer se tratasse da nobreza privilegiada do Antigo Regime, quer da plebe e da classe trabalhadora que, pela sua condição de não possuidoras, ficavam afastadas da cidadania política." SÁ, Victor de. Op.cit. p. 40.

111 "Dessa guerra saiu a sociedade portuguesa moral e culturalmente desarticulada. Não só tinha mudado radicalmente a base econômica da vida nacional como era urgente refazer desde os alicerces a sua vida espiritual" SARAIVA, António José. Herculano e o Liberalismo em Portugal. Lisboa: Livraria Bertrand, 1977, p. 45.

112 “(...) ao lado de D.Pedro, foi a Mouzinho que coube a honra de dar à revolução um caráter social, mais profundo, mais grave, mais fecundo, do que o carácter de intriga pessoal, ou de quimera doutrinária, ou de questão dinástica.” MARTINS, J.P. de Oliveira. Portugal Contemporâneo. Lisboa: Guimarães Editores, Volume I, 1996, p. 346.

${ }^{113}$ Idem, pp. 354 e 355. 
“Esta transformação é completa e revolucionária. Portugal é um dos raros países europeus onde a revolução burguesa se consumou antes de 1848. E realizou-se de maneira violenta, sob a pressão ciclónica originada pela separação do Brasil" "114.

Mas, apesar das reformas de Mouzinho da Silveira, de Joaquim António de Aguiar e Agostinho José Freire, a missão cultural $^{115}$ não era o único problema a ocupar os liberais, Portugal debatia-se em uma grave crise financeira, advinda da perda do seu poderio colonial brasileiro e de vultuosos empréstimos estrangeiros, adquiridos para sustentar os gastos da guerra civil, uma significativa divisão interna dos meios liberais causava uma crescente instabilidade política, a reintegração do grupo absolutista no poder só aumentava os descontentamentos e desorientavam ainda mais os rumos políticos e econômicos a seguir, e para finalizar, D.Pedro IV morre, vítima de tuberculose.

Com a morte de D.Pedro IV, a votação da maioridade da rainha, D.Maria II, a contestação à Carta Constitucional e a instável política ministerial (de Dezembro de 1832 a Setembro de 1836 sucederam-se sete ministérios) ${ }^{116}$, Portugal aumentou ainda mais seu campo de crise e rumou para uma nova e inevitável guerra civil, a Revolução Setembrista de 1836.

“Ao monopólio político e econômico do Estado opunham-se não apenas as camadas populares, mas diversos sectores da burguesia e até da grande burguesia que se mantinham à margem da direcção dos negócios públicos. Tais conflitos de interesses facilitaram o desabrochar do movimento democrático que em 1836, com a Revolução de Setembro, atingiria a máxima amplitude"117.

A vitória dos "setembristas", como ficaram nomeados os opositores da política ministerial de 1834 a 1836, contra os "cartistas", os chamados defensores de uma política voltada mais aos preceitos políticos da Carta Constitucional e aliados aos setores elitistas da sociedade, inauguraram um longo período de desavenças e

\footnotetext{
${ }^{114}$ SARAIVA, António José. Herculano e o Liberalismo em Portugal. Lisboa: Livraria Bertrand, 1977, p. 44.

115 "Numerosos e por vezes prósperos jornais se dedicam à divulgação de conhecimentos e à literatura para a classe média, com o Repositório Literário (1834), o Jornal Mensal de Educação, de Ferrer e Seabra (de que saiu um único número em 1835) o Jornal dos Amigos das Letras (1837), O Panorama (1837), que tirou, numa época em que a população do continente se resumia a menos de três milhões de habitantes, cinco mil exemplares, A Ilustração (1845), a Revista Universal Lisbonense, (...)” Idem, p. 48. 116 "As hesitações dos ministérios de 1834-1836, a instabilidade que os caracterizou, a lentidão da sua política reformista e a corrupção que lhes foi apontada possibilitaram o crescimento da Oposição" MARQUES, A.H. de Oliveira. "Capítulo XI - A Conjuntura". In: MARQUES, A.H. de. Oliveira \& SERRÃ̃, Joel. (direcção). Nova História de Portugal - Portugal e a Instauração do Liberalismo (volume IX). Lisboa: Editorial Presença, 2002, p. 595.

${ }^{117}$ SÁ, Victor de. Op.cit. p. 47.
} 
descontinuidades políticas que preencheram uma período de dezesseis anos (18361852).

A tradicional divisão de "setembristas" e "cartistas" está alicerçada na opção pela Constituição de 1822 ou pela Carta Constitucional de 1826, mas essa separação tão imediata revela muitas contradições e complexidades impossíveis de se revolver no presente estudo.

Sobre esse assunto o historiador Victor de Sá escreveu: "Vemos pois que as tendências constitucionais dos guias do setembrismo (entre eles Passos Manuel e Almeida Garrett), pelo menos depois da época de emigração, nada tinham de comum com os preceitos democráticos e quase republicanos da Constituição de 1822: a Carta de 1826 era para eles o estatuto predilecto" ${ }^{118 .}$.

Palavras endossadas pelo próprio Garrett, anos antes da Revolução Setembrista, no seu "Portugal na Balança da Europa” : "Tornou-se no código de 1822 por base da constituição a que real e verdadeiramente o era, foi e é o princípio democrático. Mas, por uma reacção, - exagerada certamente, porém desculpável pelos longos, pesadíssimos e ainda tão recentes agravos que a nação recebera da aristocracia, absolutamente se eliminou do novo código político o princípio aristocrático, cuja modificação era necessária para equilibrar os elementos democrático e monárquico, de que aquela constituição se compunha. Este erro, cujas causas principais foram essas, deu lugar a que a democracia legal degenerasse em demagogia ilegal (...) Daqui a incongruência e impraticabilidade do código político de 1822"119.

Sobre a superioridade da Carta de 1826 sobre a Constituição de 1822, Garrett ainda escreveu: "Tornada, como em todas as outras, a base democrática, estabelecido, como sempre, o princípio da representação popular, a Constituição de 1826 admitiu o elemento aristocrático para modificar e moderar a força democrática, e moderar e amparar o princípio monárquico, o qual assim constituído, vem a ter acção afirmativa e negativa, tanto sobre a base geral da Constituição, como sobre o elemento que a modifica. E por outro lado, esse mesmo princípio monárquico é de ambas as partes contrabalançado e contido pelos próprios elementos que modera e equilibra" ${ }^{\text {"120 }}$.

Com essas palavras, Garrett utiliza-se do princípio ilustrado do "equilíbrio de poderes" para justificar a primazia da Carta sobre a Constituição de 1822, princípio

\footnotetext{
${ }^{118}$ SÁ, Victor de. Op.cit. p. 59.

${ }^{119}$ GARRETT, Almeida. Op.cit. p. 933.

${ }^{120}$ Idem, p.934.
} 
ilustrado também utilizado por Alexandre Herculano na sua verificação da presença histórica do "princípio de liberdade" e do "princípio de desigualdade" que devem se "equilibrar" para um bom andamento social, se um deles supera o outro, há um período de "ditadura das massas" ou da "ditadura absolutista"121.

O governo "Setembrista" compreendeu dez longos anos, onde conheceu diversas orientações políticas e diversos percalços, ou seja, Portugal, nesse ínterim, foi palco de conspirações, golpes de Estado, de movimentos revolucionários e de guerras civis, até terminar em 1842, descaracterizado de seus objetivos políticos iniciais, com a restauração da Carta e com o governo de Costa Cabral.

Talvez a instabilidade política provocada pela Revolução Setembrista tenha sido resultado da pressão exercita pelas "massas populares" para que o Governo Liberal, em vigor desde 1834, se abrisse para propostas mais democráticas, e uma dessas "facções" liberais, lideradas por Passos Manuel, aproveitou-se do descontentamento da população portuguesa e tomaram o poder. Idéia também defendida por Victor de Sá e, de certo modo, por Oliveira Martins ${ }^{122}$.

Para Victor de Sá: “Após o triunfo do movimento modificou-se a relação de forças que até então facilitara o desenvolvimento democrático. As camadas da burguesia que se opunham à oligarquia dominante e que tinham mobilizado, em seu proveito, a combatividade das massas populares iam, agora que estavam no Poder, desligar-se dos seus compromissos com as forças democráticas e tentar restabelecer o equilíbrio da ordem burguesa, graças a novas alianças" ${ }^{\prime 23}$.

Em seu Portugal Contemporâneo, Oliveira Martins destaca a figura, verdadeiramente heróica, para ele, de Passos Manuel, que na sua visão tinha reais intenções "democratizantes" para a sociedade portuguesa, através de uma amplo projeto de "instrução pública" 124 , e que, a todo momento, poderia interceder em favor do povo português e da soberania popular na Corte. Como no episódio da morte de Agostinho

\footnotetext{
${ }^{121}$ Idéia de Herculano que será melhor debatida com o transcorrer do capítulo.

122 "No dia 10, de madrugada, a Guarda Nacional foi ao Paço exigir a queda do Gabinete e a proclamação da Constituição de 20. No dia 11 o Ministério caía e de tarde foi a rainha aos Paços do Concelho jurar a nova - ou antiga - Constituição. Inútil é dizer que a Câmara feita não se reuniu: era necessário fazer outra, de feitio diverso. Entretanto aclamara-se a ditadura de Passos, Vieira de Castro e Sá da Bandeira. A vitória surpreendera a todos, e mais do que ninguém aos vencedores que a não esperavam”. MARTINS, J. P. de Oliveira. Portugal Contemporâneo. Lisboa: Guimarães Editores, 1996, Volume II, p. 54.

${ }^{123}$ SÁ, Victor de. Op.cit. p. 54.

124 “À ditadura de Passos devemos, com efeito, as Escolas Politécnicas de Lisboa e Porto, as duas menos felizes Academias de Belas-Artes e o Conservatório da capital; mas à sua doutrina da paz na liberdade democrática pela instrução, não respondem acaso as revoluções dos nossos dias, (...)”. MARTINS, J.P. de Oliveira. Op.cit. p. 60.
} 
José Freire, em Novembro de 1836, na conspiração palaciana para restaurar a Carta, que Passos Manuel intercedeu pelo povo à frente da rainha D.Maria II.

“Essa fúria da populaça era a conseqüência da exaltação em que o acto agressivo do Paço lançava Lisboa e o seu povo, já soberano segundo a lei, verdadeiramente soberano agora que as Guardas Nacionais imperavam armadas. Ao som do rebate, formavam, em ordem de batalha, no Campo de Ourique, na manhã do dia 4. Parecia iminente um combate entre elas e a guarnição reunida em Belém, em torno da rainha. Passos estava no seu posto à frente do povo armado, quando vieram do Paço chamar o ditador. Que lhe queriam? Fosse o que fosse, ele partiu, arriscando a vida. (...). Passos entrou no palácio, e dir-se-ia que voltavam essas antigas cenas da Idade Média, quando os tribunos da plebe iam à frente dos monarcas ${ }^{\prime \prime 25}$.

Nas palavras acima, podemos perceber claramente, na análise histórica de Oliveira Martins, um vocabulário e um imaginário revolucionário próprio da Revolução Francesa, que conduziu tão visceralmente o historicismo romântico do século XIX, que Almeida Garrett e Alexandre Herculano fizeram parte, e que também, de certo modo, Oliveira Martins abraçou.

Para o presente estudo basta dizer que, após a queda de Passos Manuel do Congresso, em 1837, o "Setembrismo" foi se afastando, cada vez mais, de uma proposta política democratizante, vieram as intrigas ministeriais, a Constituição de $1838^{126}$, que tentava estabelecer um "elo de ligação" entre a antiga Constituição e a Carta Constitucional e, finalmente, a restauração da Carta por Costa Cabral ${ }^{127}$.

Como exemplo da complexidade do estudo envolvendo o "Setembrismo", a tentativa de síntese do período feita por Oliveira Marques é bastante esclarecedora: " $O$ Setembrismo conheceu várias fases. De Setembro a Novembro de 1836 afirmou-se contra a Corte e as suas tentativas de contra-revolução. De Novembro de 1836 a Maio de 1837 lutou contra si mesmo, acabando por perder a feição marcadamente política e

\footnotetext{
${ }^{125}$ Idem, p. 69.

126 "Com a saída de Passos o Gabinete ia todos os dias pronunciando-se mais moderado, mais razoável; e ao mesmo tempo, apesar da irritação das esquerdas no Parlamento e nos clubes, a Constituição progredia por forma que viria a ser a própria CARTA.” Ibidem, p. 84.

127 "As conquistas democráticas do setembrismo ou anteriores são anuladas: os batalhões nacionais são dissolvidos, os fabricantes e a pequena-burguesia desarmados; a descentralização administrativa efectuada pela reforma administrativa de Passos é substituída por uma organização fortemente centralizadora; ao sufrágio directo e amplo sucede o sufrágio indirecto baseado num censo elevadíssimo, que reduz o eleitorado a uma aristocracia abastada; restaura-se a antiga Câmara dos Pares hereditária, mas formada agora principalmente pela nobreza de fresca data, nascida da Revolução e da redistribuição da riqueza” SARAIVA, António José. Herculano e o Liberalismo em Portugal. Lisboa: Livraria Bertrand, 1977, p. 160.
} 
revolucionária. De Maio de 1837 a Abril de 1838 evoluiu para uma síntese entre o esquerdismo de origem e um direitismo conservador, consubstanciada na aprovação da nova Constituição. De Abril de 1838 a Junho de 1841, já sem alma, "arrastou-se" numa tentativa de simbiose que as paixões e as ambições dos seus protagonistas não permitiam. Por fim, de Junho de 1841 a Fevereiro de 1842 entrou na agonia, que viria a terminar com a restauração da Carta" ${ }^{\prime 28}$.

O governo de Costa Cabral, verdadeiro símbolo duma mentalidade aliada à nova fase do liberalismo português ${ }^{129}$, teve como objetivos principais: implantar uma ordem pública com um mínimo de oposição, princípio chave de uma ditadura, estabelecer uma ampla modernização de Portugal e instaurar uma mentalidade "modernizante"130, como a proibição dos enterros nas Igrejas, motivo de revoltas como da "Maria da Fonte".

"Na economia, obras públicas e comunicações, protegeu-se a lavoura, fomentaram-se a constituição de sociedades agrícolas e a introdução de máquinas na agricultura e na indústria, projectaram-se os primeiros caminhos-de-ferro com um plano que seria executado na década seguinte, construíram-se pontes e o canal da Azambuja, desassorearam-se e fizeram-se obras nas barras de vários rios, insistiu-se na macadamização de estradas, introduziram-se melhoramentos na construção naval, erigiram-se vários faróis na costa e estabeleceu-se o primeiro serviço regular de diligências" ${ }^{\prime 31}$.

Pelas amostras de uma política "modernizante", enumeradas por Oliveira Marques, que foi implantada por Costa Cabral para tentar livrar Portugal do "fantasma" da "decadência econômica e cultural", podemos pensar que seu governo teve uma ampla aceitação, e não foi bem assim. Seu governo caracterizou-se por uma grande corrupção e por uma situação de "favoritismo" político, que deixou descontente uma parte do próprio "partido" cartista, legado a margem dos benefícios políticos e econômicos, e

\footnotetext{
${ }^{128}$ MARQUES, A.H. de Oliveira. Op.cit. p. 598.

129 "Se ele (Costa Cabral) se propunha defender os ricos para consolidar a ordem, (...), ou se, menos idealista nas suas vistas, queria a ordem apenas como instrumento de enriquecimento do País, é o que nos não sentimos habilitados a dizer; pensando, contudo, mais provável a segunda hipótese. Como quer que seja, era por esta que a sociedade opinava, já começava a converter-se ao materialismo, sob a primeira forma com que ele modernamente apareceu; era para o materialismo prático que a sociedade, desiludida das quimeras liberais, começava a pender”. LIMA, J. P. de Oliveira. Op.cit. p. 134.

130 "Os méritos da nova situação foram, todavia, anulados pelos deméritos de um regime de compadrio e de imoralidade política e econômica. Mais do que um dirigente de partido, António Bernardo da Costa Cabral revelou-se em breve um chefe de clã. Uma vasta clientela de apaziguados, incluindo membros da família mais chegada, cercou o poder e beneficiou dele de maneira havida por escandalosa (...). $O$ compadrio e a falta de transparência verificaram-se ainda na esfera econômica, sobretudo no que respeitou à participação do Estado em companhias e obras de fomento” Idem, p. 604.

${ }^{131}$ Ibidem, p.606.
} 
ainda recebeu violentas críticas de grupos populares voltados a uma mentalidade "tradicionalista" avessa à modernização implantada em Portugal.

Aproveitando-se da situação de instabilidade política em Portugal, o "partido" dos setembristas começou a organizar alianças para depor Costa Cabral, iniciando um novo período de guerras civis e de ampliação da complexa rede de objetivos e programas liberais. Combatendo lado a lado nós tínhamos setembristas, anticabralistas e até mesmo miguelistas antiliberais, assessorados por uma massa populacional descontente, com a corrupção do Cabralismo e com as abruptas mudanças modernizadoras, e clamando por melhores condições de vida.

"A complexidade da revolta tudo permitia. Além daquelas forças, bem definidas, imiscuíam-se nela, em termos mais vagos, uma revolta do campo contra a cidade, do localismo contra a centralização, da tradição contra a modernidade, da religião contra a Maçonaria, dos fidalgos e terratenentes locais contra a nova nobreza e a burguesia endinheirada, em suma do Antigo Regime contra o Liberalismo. Era o estrebuchar final de um mundo agonizante e ultrapassado" ${ }^{132}$.

O final do período cabralista foi marcado por uma situação econômica e política que beirou ao caos. Os setembristas, organizadores das revoltas contra Costa Cabral, aumentavam, cada vez mais, sua influência política e aguardavam a abolição da Carta e a formulação de uma nova Constituição. A situação política e econômica do país aguardava uma definição, estava suspensa, em aberto, vítima de posicionamentos ideológicos contrários e de inúmeras guerras civis. Símbolo da instabilidade do período coube à Patuléia, anunciada por Oliveira Marques como “(...) uma das mais violentas e duradouras guerras civis de Portugal" ${ }^{, 133}$, e também extremamente complexa para abordar numa pequena enumeração e interpretação dos fatos políticos para os objetivos do presente estudo, e o retorno de Costa Cabral do exílio.

“A criação de infra-estrutura e outros aspectos da modernização, que o Cabralismo procurara acelerar, achavam-se interrompidas. Portugal, que atingira um dos pontos mais baixos do seu declínio oitocentista, sofria uma profunda crise de confiança interna e externa" ${ }^{\prime 134}$.

No final de um longo período de crises e de contendas políticas liberais, todos os "medos" de uma democracia popular são irrevogavelmente afastados, só ressurgindo,

\footnotetext{
${ }^{132}$ Ibidem, p. 608.

${ }^{133}$ Ibidem, p. 612.

${ }^{134}$ Ibidem, p. 616.
} 
novamente, com a "Geração de 70". A rainha D.Maria II triunfou com o desgaste dos liberais "radicais", reorganizados sob a égide do nascente "Partido Nacional", e arquitetou a volta triunfante da Carta Constitucional e do "materialismo" burguês ${ }^{135}$, com a instauração do período da "Regeneração" (1851-1868) ${ }^{136}$.

Após um breve panorama da conjuntura política que guiou a nação portuguesa na primeira metade do século XIX, cabe introduzir as principais idéias políticas, sociais e culturais defendidas por Almeida Garrett e Alexandre Herculano. Homens públicos ligados a uma intensa reflexão sobre o seu período histórico e, atuantes na definição de novos rumos para a cultura portuguesa.

\subsection{Almeida Garrett e Alexandre Herculano - românticos e liberais:}

A atuação política dos dois grandes expoentes da primeira geração romântica de Portugal $^{137}$ estava aliada a um intenso trabalho intelectual que pensava os problemas da nação, composto de reflexões que giravam em torno de questões culturais, sociais (pedagógicas), políticas e econômicas. Como no modelo ilustrado intelectual anterior, do consulado pombalino e do governo joanino e, também dialogando com o modelo constitucional liberal da Revolução de 1820 e da Carta Constitucional de 1826.

Como já foi apontado o Romantismo, e no caso português não foi diferente, herdou as premissas do movimento iluminista, mas também se constituiu como conseqüência do deslocamento crítico e do conjunto de valores (ou visão de mundo romântica) de alguns intelectuais em relação à configuração de uma "modernidade capitalista" gerida por relações quantitativas, ou seja, relações sociais motivas pelo utilitarismo e por

\footnotetext{
135 “O princípio do individualismo anárquico e liberal, destruidor do passado e da tradição, criador de uma nova classe de ricos saídos da concorrência, tinha de acabar num cepticismo sistemático e numa confissão formal da idolatria da Utilidade, depois de ter percorrido o círculo de experiências e ensaios possíveis dentro das fórmulas e depois de ter demonstrado o vazio de todas elas. Num país caduco, essa evolução fazia-se muito mais rapidamente: por isso era já impossível sair do doutrinarismo para o idealismo republicano, (...)” MARTINS, J.P. de Oliveira. Op.cit. Volume II, p. 234.

136 "Em 1 de Maio de 1851 a rainha convidava formalmente Saldanha a formar governo. Duas semanas depois, o triunfador entrava na capital, delirantemente ovacionado. Começava a Regeneração” MARQUES, A.H. de Oliveira. Op.cit. p.618.

${ }^{137}$ A periodização considerada para a primeira geração do Romantismo português é a mesma exposta no trabalho de Alberto Ferreira. Periodização que vai de 1834 a 1846 e é justificada como escolha devido "ao definitivo triunfo da burguesia sobre as instituições monárquicas-feudais (considerando a vitória contra o absolutismo de D.Miguel e o "triunfo da burguesia" com a Revolução de Setembro) e o triunfo da fracção burguesia liberal sobre o radicalismo da pequena burguesia ou das camadas populares mais esclarecidas”. FERREIRA, Alberto. Perspectiva do Romantismo português. Portugal, Lisboa: Moraes Editores, 1979, p.32.
} 
anseios de lucro. Do mesmo modo que as mudanças estruturais impulsionadas pela Revolução Industrial afetaram a mentalidade da primeira geração do romantismo português, não foi diferente com as consequências paradigmáticas da Revolução Francesa $^{138}$.

"O romantismo de classe, temperado de disciplina, manifesta-se em todos os planos da vida social, militar, artística, política, mundana; na eloqüência parlamentar, na magistratura, na vida amorosa, no jornalismo. As esperanças, duramente dominadas pelo antigo regime, puderam finalmente exprimir-se numa sociedade em transformação. Os germes progressistas do iluminismo afloraram. As perspectivas dos homens que se formaram entre 1817 e 1834 alargaram-se e forçaram o espartilho das convenções e das normas tradicionais. $O$ artista do primeiro romantismo situa-se no enquadramento duma cidade que se pretende libertar" $" 139$

\subsubsection{Almeida Garrett: Ilustração e Romantismo:}

João Baptista da Silva Leitão de Almeida Garrett (Porto, 04/02/1799 - 09/12/1854) teve uma formação bastante eclética e variada, fruto do estudo do latim, grego, aritmética e geometria, que lhe deu um amplo conhecimento da cultura clássica, da permanência no curso de Direito da Universidade de Coimbra, onde tomou contato com as idéias liberais e das experiências do exílio, Inglaterra e França, importantes para definir o lado "romântico" de Garrett ${ }^{140}$.

Garrett foi o típico homem culto português e europeu do século XIX, preocupado com a renovação da cultura e da política da nação. Lutou ao lado de Alexandre Herculano no exército de D.Pedro IV contra o absolutista D.Miguel, foi Cônsul Geral na Bélgica, deputado durante o Setembrismo, amigo íntimo de Mouzinho da Silveira e

\footnotetext{
${ }^{138}$ Conseqüências que colocaram para o seu tempo, como em nenhum outro exemplo revolucionário, novas possibilidades idealistas no campo da política e na organização social. "A Revolução Francesa, com todos os seus desdobramentos, e a Revolução Industrial, a tomar impulso,(...),foram vistas como desencadeadoras de forças incontroláveis que impulsionaram a sociedade na direção de um desenlace imprevisto, mas quase inevitável" SALIBA, Elias Thomé. As utopias românticas. São Paulo: Estação Liberdade, 2003, p.15.

${ }^{139}$ FERREIRA, Alberto. Op.cit. p.50.

140 “Quando em 1823 chegou à Inglaterra e entrou a conviver com uma família inglesa, Garrett, foi fascinado por este mundo novo. Estava no auge a evocação da Idade Média, das ruínas góticas, do folclore. Walter Scott, ainda vivo, publicara já os seus poemas narrativos de assunto medieval, os seus romances históricos e os seus Cantos da fronteira inglesa (1802-1803)”. SARAIVA, António José \& LOPES, Óscar. História da Literatura Portuguesa. Portugal: Porto Editora, 1975, p.759.
} 
de Passos Manuel e organizador do Teatro Nacional português, enumerando apenas algumas faces de um escrito profícuo e de profundas idéias.

"Ao contrário do que acontece com Herculano, mais novo, que se formou directamente numa estética romântica de tipo alemão, da qual foi aliás o primeiro doutrinário resoluto, o jovem Garrett apenas parece ter assimilado o cristianismo sentimental de Chateaubriand e o relativismo histórico e nacional teorizado por Madame de Stael a uma concepção de vida basicamente arcádica e iluminista, e a sua evolução em sentido romântico faz-se de um modo gradual e contra-pesado de eclectismos teóricos ou estilísticos" ${ }^{, 141}$.

Tanto o lado "ilustrado" quanto o lado "romântico" de Garrett podem ser claramente percebidos nos seus muitos escritos, em especial, seus famosos poemas "Camões" e "D.Branca"142, seus ensaios "Bosquejo da História da Poesia e Língua Portuguesa", "Da Educação" e "Portugal na Balança da Europa", romances "Viagens na Minha Terra" e "O Arco de Sant'Ana" e no drama histórico "Frei Luís de Sousa". Todos voltados a uma proposta de diálogo com a nova mentalidade cultural da Europa e reféns de uma preocupação pedagógica, típica da ilustração, e política.

"Se bem que por formação e tendência natural fosse um literato, compreendeu a importância da conexão histórica entre arte e sociedade. Este penetrante sentimento de totalidade histórica e mais a idéia de progresso animando todo o conjunto das antigas atividades humanas, colheu-os na leitura dos enciclopedistas - os Voltaires e Rousseaus da sua mocidade, como pitorescamente evocará" ${ }^{143}$.

No seu "Bosquejo da História da Poesia e Língua Portuguesa”, publicado em Paris, no ano de 1826, Almeida Garrett estabelece uma espécie de panorama crítico sobre a cultura literária de Portugal, tentando identificar os períodos de "decadência" cultural e aqueles em que a produção literária esteve mais próxima de uma identificação

\footnotetext{
${ }^{141}$ Idem, p.754.

${ }^{142}$ É interessante notar a ambiência romântica captada por António José Saraiva nos dois poemas de Garrett, sobre "Camões" escreve: "Em todo o poema domina um tom de elegia lutuosa, e são reconhecíveis temas do romantismo europeu, de Rousseau, Byron e outros (bondade natural humana recalcada pela civilização; individualismo insociável; etc) e outros temas de uma espécie de préromantismo nacional latente ( saudosismo; solidão bernardiana e camoniana; etc)” Ibidem, p.761. “ $O$ mesmo se patenteia na D.Branca redigida contemporaneamente, história em verso de uma infanta portuguesa raptada pelo último rei mouro de Silves. $O$ autor introduziu-lhe vários ingredientes típicos: o exótico oriental; o maravilhoso folclórico português de fadas, mouras encantadas, magia da noite de S.João, etc.; a tradição da feitiçaria medieval, representada por S.Frei Gil, espécie de Fausto português; a intervenção de cadáveres e esqueletos, segundo o gosto de Buerger, Schiller e outros. Procurou, em suma, uma acumulação dos elementos exteriores do Romantismo” Ibidem, p.762.

${ }^{143}$ FERREIRA, Alberto. Op.cit. p.53.
} 
com os costumes e "feições naturais". Um ensaio revolucionário no sentido de firmar um novo "caráter" para a cultura nacional portuguesa.

$\mathrm{Na}$ primeira época literária de Portugal, que Garrett estabelece entre os fins do século XIII até os princípios do século XVI, há um período de crescimento cultural até a morte de "el-rei" D.Manuel, mas identifica esse crescimento com a capacidade dos escritores criarem uma arte em sintonia com as "cores nacionais". Nesse julgamento artístico Garrett dialoga, mais uma vez com o universo romântico e com seus conceitos chaves, como do "espírito do povo".

Sobre os poetas do período, Garrett escreve: "A natural suavidade do idioma português, a melancolia saudosa de seus números nos levaram à cultura deste gênero pastoril, em que raro nosso poeta deixou de escrever, quase todos bem, porque a língua os ajudava; nenhum perfeitamente, porque (inda mal) deram às cegas em imitar Sanazaro, depois Boscan e Garcilasso, e copiaram pouco do vivo da Natureza, que tão bela, tão rica, tão variada se lhes presenteava por todas as quatro partes de que em breve constou o mundo português, e das quais todas ou assunto ou lugar de cena tiraram nossos bucólicos.(...). O Tejo, o Mondego, os montes, os sítios conhecidos de nosso país e dos que nos deu a conquista, figuram em seus poemas; porém raro se vê descrição que recorde alguns desses sítios que já vimos, que nos lembre os costumes, as usanças, os preconceitos mesmo populares; que daí vem à poesia o aspecto e feições nacionais, que são sua maior beleza" ${ }^{144}$.

Para o julgamento estético romântico de Garrett, a arte deveria captar todos os aspectos, positivos e negativos, da "índole nacional", representada de maneira mais integral na vivência cultural popular.

Na segunda época literária, analisada por Garrett, que vai dos princípios do século XVI até os do século XVII, há um cultivo das línguas clássicas e, consequentemente, uma aproximação da produção literária com os modelos gregos e romanos. Com isso, a poesia nacional ganhou “(...) na delicadeza, na harmonia, no gosto; porém desmereceu muito, demasiado na originalidade, no carácter próprio, que perdeu quase todo, em a nacionalidade, que por mui pouco se the ia (...) e mui pouco ficou para o que era nacional,para o que já tínhamos, para o que naturalmente devia nascer de nossos usos,

\footnotetext{
${ }^{144}$ GARRETT, Almeida. "Bosquejo da História da Poesia e Língua Portuguesa". In:Obras de Almeida
} Garrett - vol.1. Porto: Lello \& Irmão Editores, 1963, p.488. 
de nossas recordações, de nossa arqueologia, do aspecto de nosso país, de nossas crenças populares, e enfim de nossa religião" ${ }^{145}$.

Com as enunciadas considerações de Garrett no "Bosquejo", fica clara uma nascente mentalidade romântica que irá se preocupar em definir uma produção cultural historicamente fundamentada em relação aos costumes tradicionais do povo português e com um resgate afetivo, das "recordações" e da "religião", do âmbito individual e coletivo. Da mesma forma, Alexandre Herculano estabeleceu a necessidade de um novo "caráter" para a produção literária nacional com seus ensaios "Qual é o estudo da nossa literatura? Qual é o trilho que ela hoje deve seguir?" e "Poesia (Imitação - Bello Unidade)" publicados na revista Repositório Literário.

Dentro dessa segunda época literária é interessante o julgamento que Garrett faz de Camões, valorizando-o a partir de sua originalidade, criatividade e senso nacional ${ }^{146}$, palavras de ordem para uma estética romântica imbuída da figura do "gênio".

Tanto a terceira época, começo até o fim do século XVII, quanto a quarta época, fins do século XVII até meados do século XVIII, são marcadas por um "corromper-se do gosto" e "declínio da língua". Situação de "decadência" proporcionada pela influência dos valores da estética estrangeira, marcada pelo gongorismo, que afastava os poetas duma verdadeira arte nacional.

Segundo Garrett: “Tínhamos perdido a independência, perdemos logo o espírito nacional, o timbre, o amor pátrio (que amor, da pátria poderá haver em quem pátria já não tem); a lisonja servil, a adulação infame levou nossos desonrados avós a desprezar seu próprio riquíssimo e tão suave idioma, para escrever no gutural castelhano, preferindo os sonoros helenismos dos portugueses às aspiradas arávias da língua dos tiranos" $" 147$. Para Garrett, com essas palavras, a valorização da língua nacional pelos seus poetas, era o que definia o "espírito de um povo", e era a partir da língua, que para ele, se revelavam as principais diferenças de costumes. Sentença típica de uma atenta leitura romântica ${ }^{148}$.

\footnotetext{
${ }^{145}$ Idem, p.490.

${ }^{146}$ Camões para Almeida Garrett: “(...) viu tudo pequeno à roda de si, todos os poetas pigmeus, todos acanhados com as línguas modernas ainda mal perfeitas, escravos da imitação clássica, incertos $e$ entalados todos entre o cego respeito da Antiguidade e as novas precisões que as novas idéias, que o novo estado do mundo requeria. Teve ânimo para conceber e força para executar um rasgado e necessário atrevimento de se abrir caminho novo, de criar enfim a poesia moderna, dar não só a Portugal, mas à Europa toda um grande exemplo, e constituir-se o Homero das línguas vivas" Ibidem, p. 493.

${ }^{147}$ Ibidem, p.496.

148 "A elevada cotação que a filosofia e a literatura alemãs tinham atingido quer em França quer em Inglaterra, levou Garrett e Herculano a aprender o alemão”. (...). "Sabe-se ainda que Garrett lera, por
} 
A quinta época literária em Portugal caracterizou-se por um período de restauração, que compreende da metade do século XVIII até o século XIX de Garrett. Nesse recorte temporal instituído por Garrett, as mudanças mais significativas se determinaram pelo "intercâmbio cultural" e pela disseminação do "espírito" das Luzes na Europa.

“A França viu então o século de Luís XVI; Itália deixou São Tomás e os concetti por melhor filosofia e melhor gosto; Espanha teve o seu Carlos II; e Portugal no reinado de el-rei D.José subiu à altura dos outros povos, senão é que em muitas coisas acima" 149 .

As análises de Garrett nesse pequeno ensaio sobre a literatura portuguesa mesclamse com uma visão herdeira da ilustração com valiosas sentenças anunciadoras de um "despertar" romântico. Como na sua caracterização da poesia árcade produzida no Brasil, onde a Natureza, percebida como experiência estética, e a importância de aliar a arte à ambiência local, ganham destaque dentro do seu campo de valor artístico.

Sobre o Brasil, Garrett escreve: "Certo é que as majestosas e novas cenas da Natureza naquela vasta região deviam ter dado a seus poetas mais originalidade, mais diferentes imagens, expressões e estilo, do que neles aparece: a educação européia apagou-lhes o espírito nacional: parece que receiam de se mostrar americanos; e daí lhes vem uma afectação e impropriedade que dá quebra em suas melhores qualidades. (...) quisera eu que em vez de nos debuxar no Brasil cenas da Arcádia, quadros inteiramente europeus, pintasse os seus painéis com as cores do país onde os situou" ${ }^{\prime 150}$.

Para finalizar essa breve análise, basta citar a posição de Garrett perante a cativante figura de Bocage, apontado por muitos críticos como o "pré-romântico" por excelência em Portugal. A importância de Bocage, para Garrett, emana justamente nos seus temas e na subjetividade que desperta nas letras portuguesas. "O fogo de suas idéias ateou o entusiasmo geral; a mocidade inflamou-se com o nome de Bocage"151. "Porém nos intervalos lúcidos que a Bocage deixava o fatal desejo de brilhar, nalguns instantes que, despossesso do demônio das hipérboles e antíteses, ficava seu grande engenho a

volta de 1822, o volume de ensaios Vorlesungen uber dramatische Kunst und Literatur (Conferências sobre Arte Dramática e Literatura) de A.Wilhelm Schlegel (Antscherl, 1927)”. COSTA, Gil F.

"Romantismo Alemão (Leituras e Contatos). In: BUESCU, Helena Carvalhão (Coord.). Dicionário do

Romantismo Literário Português. Lisboa: Editorial Caminho S.A., 1997, p. 494.

${ }^{149}$ GARRETT, Almeida. Op.cit. p. 501.

${ }^{150}$ Idem, pp. 503 e 504.

${ }^{151}$ Ibidem, p. 506. 
sós com a Natureza e em paz com a verdade, então se via a imensidade dessa grande alma, a fina têmpera desse raro engenho (...)"152.

O romance "Viagens da Minha Terra" desponta como uma das obras mais significativas da produção literária de Garrett, por conter indicações sobre suas posições políticas, por realizar um intenso diálogo com os temas do Romantismo e por fazer referências a uma produção literária européia marcante para a época ${ }^{153}$.

Publicado, inicialmente, de um período que vai de 1843 até 1845, na Revista Universal Lisbonense, somente em 1846, aparece em volume. Portugal, nessa época, vivia o cabralismo, a instabilidade política e o retorno da Carta Constitucional.

O romance representou uma verdadeira revolução literária em Portugal por abordar reflexões de Garrett na viagem a Santarem e por contar a história de amor de Carlos, combatente liberal, e Joaninha, sua prima e símbolo da pureza da vida do campo.

Além de apresentar muitos temas oriundos de uma visão de mundo romântica, Garrett também explora o deslocamento de Carlos perante quadros sociais divergentes, que lhe pedem uma conduta moral variável. Como no início da narrativa que é um apaixonado pela causa liberal e por Joaninha e que depois, torna-se um rico "barão" (símbolo do burguês acumulador de capital e ligado, somente, a questões materiais e quantitativas).

Sobre essa transformação de Carlos, Garrett já a enuncia no início da narrativa, como um prenúncio do irremediável. Nas suas reflexões introdutórias, o autor faz um amplo panorama da sociedade européia do oitocentos, de seus valores e códigos éticos, obedecendo uma típica crítica romântica diante da "modernidade capitalista burguesa".

Vejamos uma parte desse significativo trecho, que não deixa dúvidas a respeito do "romantismo" de Garrett:

"Quantas almas é preciso dar ao diabo e quantos corpos se têm de entregar no cemitério para fazer um rico neste mundo. - Como se veio a descobrir que a ciência deste século era uma grandessíssima tola."(...). "Não: plantai batatas, ó geração de vapor e de pó de pedra, macadamizai estradas, fazei caminhos de ferro, construí passarolas de Ícaro, para andar a qual mais depressa, estas horas contadas de uma

\footnotetext{
152 Ibidem, p. 508.

153 “Tomando como modelo Viagem à roda do meu quarto, de Xavier de Maistre, e Viagem sentimental, de Lawrence Sterne, Garrett escreve uma obra de difícil classificação, pois reúne nela o relato jornalístico, o ensaístico e o ficcional. O plano temporal também é múltiplo: o presente abrange o período da viagem a Santarém, no ano de 1843; o passado recente remete para a época das lutas entre liberais e miguelistas, de 1830 a 1834; o passado remoto conduz aos primórdios do século, (...)” VECHI, Carlos Alberto. “A estética romântica”. In: MOISÉS, Massaud. (Org.). A Literatura Portuguesa em Perspectiva. Vol.III. São Paulo: Editora Atlas S.A., 1994, p. 39.
} 
vida toda material, maçuda e grossa como tendes feito esta que Deus nos deu tão diferente do que a que hoje vivemos. (...). Logo a nação mais feliz, não é a mais rica. Logo o princípio utilitário é a mamona da injustiça e da reprovação" ${ }^{\text {"154 }}$.

O romance é perpassado por uma fina ironia, que recai sobre a própria estética romântica, por digressões e vários recursos de linguagem, tudo para provocar a reflexão e a identificação do leitor com as situações apresentadas pelo autor.

Sobre a construção do próprio romance, Garrett remete-se ao leitor: "Trata-se de um romance, de um drama - cuidas que vamos estudar a história, a natureza, os monumentos, as pinturas, os sepulcros, os edifícios, as memórias da época? Não seja pateta, senhor leitor, nem cuide que nós somos. Desenhar caracteres e situações do vivo na natureza, colori-los das cores verdadeiras da história...isso é trabalho difícil, longo, delicado, exige um estudo, um talento, e sobretudo um tato!...Não senhor: a coisa faz-se muito mais facilmente. Eu lhe explico. Todo o drama e todo o romance precisa de: Uma ou duas damas, Um pai, Dois ou três filhos, de dezenove a trinta anos, Um criado velho, Um monstro encarregado de fazer as maldades,(...)",155.

Com um amplo conhecimento da literatura romântica, cita "Os salteadores” de Schiller, Alexandre Dumas, Eugene Sue, Victor Hugo, Gessner, “Fausto” de Goethe entre outros, e com sua ácida ironia, Garrett tem a intenção de ultrapassar a função mais imediata de um romance para a época, vender e servir de puro entretenimento. Quer revelar aquilo que está nas "entrelinhas" da literatura da época e do "simples" enredo de seu romance. Garrett, assim como Herculano, têm a literatura como uma "missão cultural", querem revelar os males da vida social do oitocentos e configurar uma literatura nacional.

Há uma infinidade de eixos temáticos dentro do romance de Garrett, mas alguns parecem ganhar importância dentro de uma visão de mundo romântica, podemos destacar: a luta de um sentimento de esperança diante da desesperança diante do homem e dos acontecimentos políticos e históricos, a simplicidade da vida do campo diante dos artificialismos da vida citadina e o sentimento do amor ${ }^{156}$.

\footnotetext{
${ }^{154}$ GARRETT, Almeida. Viagens na Minha Terra. São Paulo: Ediouro Publicações S.A./Publifolha, 1997, pp.46 e 48.

${ }^{155}$ Idem, p. 55.

156 "É assim que, nas páginas das Viagens, passamos da descrição da paisagem ribatejana às reflexões desiludidas sobre o materialismo do século, da sátira da literatura romântica à análise de um romance popular, das evocações históricas aos devaneios líricos, da política às confidências e à delicada história de Joaninha. É uma verdadeira vagabundagem do espírito que Garrett, num tom artisticamente despreocupado, se abandona, convidando a segui-lo o leitor, seduzido pela atmosfera de intimidade
} 
Sobre o embate entre esperança e desesperança, Garrett reporta ao prazer das leituras de Camões: "E contudo, desde a idade da inocência em que tanto me divertiam aquelas batalhas, aquelas aventuras, aquelas histórias de amores, aquelas cenas todas, tão naturais, tão bem pintadas - até esta fatal idade da experiência, idade prosaica em que as mais belas criações do espírito parecem macaquices diante das realidades do mundo, e os nobres movimentos do coração quimeras de entusiastas, até esta idade de saudades do passado e esperanças no futuro, mas sem gozos no presente, em que o amor da pátria (também isto será fantasmagoria?) e o sentimento íntimo do belo me dão na leitura do Lusíadas outro deleite diverso, mas não inferior ao que noutro tempo me deram (...)"157.

Sobre a simplicidade do campo e o culto da Natureza, como experiência estética e reveladores de um subjetivismo romântico, Garrett escreve: "Que delicioso aroma selvagem que exalam estas plantas, acres e tenazes de vida, que a cobrem, e que resistem verdes e viçosas a um sol português de julho! A doçura que mete na alma (...) A majestade sombria e solene de um bosque antigo e copado, o silêncio e escuridão de suas moitas mais fecundas, o abrigo solitário de suas clareiras, tudo é grandioso, sublime, inspirador de elevados pensamentos. Medita-se ali por força; isola-se a alma dos sentidos pelo suave adormecimento em que eles caem... e Deus, a eternidade - as primitivas e inatas idéias do homem - ficam únicas no seu pensamento..." 158

Joaninha, a enamorada de Carlos, o símbolo da preservação da simplicidade que é destruído no final do romance, também é denominada pelo nosso autor de "menina dos rouxinóis". Mas, por que a escolha desse epíteto? Joaninha mora em Santarém, nunca saiu de Santarém, ao contrário do primo Carlos, terra apresentada como um verdadeiro "Paraíso" na Terra e mais agradável que famosos lugares da Europa moderna. Joaninha,portanto, também representa o que é Santarém.

Cá estamos num dos mais lindos e deliciosos sítios da terra: o vale de Santarém, pátria dos rouxinóis e das madressivas, cinta de faias belas e de loureiros viçosos. Disto é que não tem Paris, nem França, nem terra alguma do ocidente senão a nossa terra (...)”. “(...) a paz, a saúde, o sossego do espírito e o repouso do coração devem viver ali, reinar ali um reinado de amor e benevolência. As paixões más, os

criada com esse espírito fino, culto, artista e “dilettante”” MONTEIRO, Ofélia M. Caldas Paiva.

“Introdução”. In: GARRETT, Almeida. Viagens na Minha Terra. Portugal: Atlântida, 1973, p. 15.

${ }^{157}$ GARRETT, Almeida. Viagens na Minha Terra. São Paulo: Ediouro Publicações S.A./Publifolha, 1997, p.60

${ }^{158}$ Idem, p.70. 
pensamentos mesquinhos, os pesares e as vilezas da vida não podem senão fugir para longe. Imagina-se por aqui o Éden que o primeiro homem habitou com a sua inocência e com a virgindade de seu coração" 159 .

Joaninha, como os rouxinóis de Santarém, é pura, simples, bela de uma maneira toda especial, sem males e sem vícios, não foi corroída e fraturada pelos centros urbanos e seus interesses "mesquinhos", é, assim como a Lotte de Werther, o símbolo da mulher romântica. Joaninha é toda a poesia romântica ${ }^{160}$.

Outro embate de "tipos" sociais, representantes de princípios morais e "visões" de mundo divergentes, presente no romance, configura-se entre o frade, representante de um mundo desgastado e voltado a uma perspectiva espiritual, e a figura do barão, o acumulador de capital e símbolo do "desencantamento" promovido pela modernidade capitalista.

“O frade era, até certo ponto, o Dom Quixote da sociedade velha. O barão é, em quase todos os pontos, o Sancho Pança da sociedade nova. (...) O barão é pois usurariamente revolucionário, e revolucionário usurário. "161

"Ora o frade foi quem errou primeiro em nos não compreender, a nós, ao nosso século, às nossas inspirações e aspirações: com o que falsificou a sua posição, isolouse da vida social, fez da sua morte uma necessidade, uma coisa infalível e sem remédio. Assustou-se com a liberdade que era sua amiga, mas que o havia de reformar, e uniu-se ao despotismo que o não amava senão relaxado e vicioso, porque de outro modo não lhe servia nem o servia. Nós também erramos em não entender o desculpável erro do frade, em lhe não dar outra direção social, e evitar assim os barões, que é muito mais daninho bicho e mais roedor" 162 .

Utilizando-se de metáforas e outros recursos de linguagem, Garrett expõe a complexidade e contradições da modernidade. De um lado, a "sociedade nova" trouxe a liberdade, mas de outro revelou as auguras de um materialismo desumano e cínico. $\mathrm{O}$ "frade" se aliou ao Despotismo por não conseguir separar a liberdade da "visão de

\footnotetext{
${ }^{159}$ Ibidem, p.78.

160 “(....... Os olhos de Joaninha eram verdes...não daquele verde descorado e traidor da raça felina, não daquele verde mau e destingido que não é senão azul imperfeito, não, eram verdes-verdes, puros $e$ brilhantes como esmeraldas do mais súbito quilate. São os mais raros e os mais fascinantes olhos que há” GARRETT, Almeida. Ibidem, p. 90.

${ }^{161}$ Idem, p.93.

162 Ibidem, p. 94.
} 
mundo" dos "barões" capitalistas ${ }^{163}$. No livro, essa luta de princípios, liberdade contra despotismo, encantamento versus desencantamento e tradição contra progresso acaba sendo travada entre liberais e miguelista ("realistas") e entre Carlos e Frei Dinis.

Além de uma miríade de temas, o romance trata do amor entre Carlos e Joaninha, situação que também serve de desculpa para que Garrett faça sua crítica de costumes.

Carlos, um soldado liberal e cansado da guerra ${ }^{164}$, encontra uma paz momentânea na sua terra da infância, Santarém, e nos braços de sua doce e gentil prima. O amor devotado de Joaninha lhe traz conforto e um momentâneo esquecimento do atribulado mundo urbano, com seus códigos de conduta e frivolidades ${ }^{165}$.

Carlos, mesmo possuído de encantamento por Joaninha, também amava outra, Georgina, e tudo que ela representava, nobreza, riqueza, fama e cultura. Do mesmo modo que Joaninha resguardava em si o valor da simplicidade, Georgina era o símbolo da mulher urbana e bem educada, conhecedora de todos os códigos de conduta sociais e freqüentadora da alta sociedade européia.

O nosso autor, numa crítica romântica balizada por Rousseau, revela as mentiras e o falso progresso dessa sociedade moderna atraente para Carlos.

“Formou Deus o homem, e o pôs num paraíso de delícias; tornou a formá-lo a sociedade, e o pôs num inferno de tolices.

O homem - não o homem que Deus fez, mas o homem que a sociedade tem contrafeito, apertando e forçando em seus moldes de ferro aquela pasta de limo que no paraíso terreal se afeiçoara à imagem da divindade - o homem assim aleijado como nós o conhecemos, é o animal mais absurdo, o mais disparatado e incongruente que habita na terra.

\footnotetext{
${ }^{163}$ Não podemos esquecer do contexto histórico em a obra foi escrita. Em pleno período Cabralista que trouxe para Portugal os avanços técnicos- industriais, como as estradas de ferro, e a mentalidade da modernidade capitalista. Denunciada em seus excessos por Garrett na figura simbólica dos "barões". 164 "No entretanto a guerra civil progredia; e depois de suas tremendas peripécias, o grande drama da Restauração chegava rapidamente ao fim. Eram meados do ano de 33, a operação do Algarve sucedera milagrosamente aos constitucionais, a esquadra de D.Miguel fora tomada, Lisboa estava em poder deles. Os tardios e inúteis esforços dos realistas para retomar a capital tinham ocupado o resto do verão." GARRETT, Almeida. Op.cit. p.120.

165 "As estrelas luziam no céu azul e diáfano, a brisa temperada da primavera suspirava brandamente; na larga solidão e no vasto silêncio do vale distintamente se ouvia o doce murmúrio da voz de Joaninha, claramente se via o vulto da sua figura e da do companheiro que ela levava pela mão e que maquinalmente a seguia como sem vontade própria, obedecendo ao poder de uma magnetismo superior e irresistível" (...). "Oh! Que imagem eram esses dois, no meio daquele vale nu e aberto, à luz das estrelas cintilantes, entre duas linhas de vultos negros, aqui e ali dispersos e luzindo acaso do transiente reflexo que fazia brilhar uma baioneta, um fuzil...que imagem não eram dos verdadeiros e mais santos sentimentos da natureza expostos e sacrificados sempre no meio das lutas bárbaras e estúpidas, no conflito de falsos princípios em que se estorce continuamente o que os homens chamaram sociedade!.” Idem, pp.132 e 133.
} 
(...) formou a sociedade, em sua vã sabedoria, um sistema quimérico, desarrazoado e impossível, complicado de regras a qual mais desvairada, encontrando de repugnâncias a qual mais oposta. E vazado este perfeito modelo de sua arte pretensiosa, meteu dentro dele o homem, desfigurou-o, contorceu-o, fê-lo o tal ente absurdo e disparatado, doente, fraco, raquítico (...)" ${ }^{\prime 66}$.

Dentro dum imaginário romântico, onde os temas da simplicidade, do contato da natureza e da "bondade" original do homem corrompida pela sociedade são retomados por Garrett, há um esboço da valorização do sentimento e da conduta apaixonada em detrimento de uma racionalização das atitudes e da busca da praticidade imposta pela sociedade moderna.

“Carlos estava quase como os mais homens...ainda era bom e verdadeiro no primeiro impulso de sua natureza excepcional; mas a reflexão descia-o à vulgaridade da fraqueza, da hipocrisia, da mentira comum. (...) Dúvida, incerteza, vaidade, mentira, deslocavam e anulavam a bela organização daquela alma." 167

Com a loucura de Joaninha e a transformação do idealista Carlos em "barão", Garrett encerra seu romance com uma série de ironias a cerca do futuro inglório de Portugal, que optou pela inércia das sociedades materialistas e esqueceu sua nobreza de sentimentos e atitudes morais passadas.

“Quero acreditar que tal não podia suceder aos túmulos de D.Dinis, D.Pedro I, dos dois Joanes I e II, de...

(...)

E Portugal não há religião de nenhuma espécie. Até a sua falsa sombra, que é hipocrisia, desapareceu. Ficou o materialismo estúpido, alvar, ignorante, devasso e desfaçado, a fazer gala de sua hedionda nudez cínica no meio das ruínas profanas de tudo o que elevava o espírito...

\section{(...)}

Mais dez anos de barões e de regime da matéria, e infalivelmente nos foge deste corpo agonizante de Portugal o derradeiro suspiro do espírito." 168

Mesmo com um quadro de desesperança apresentado por Garrett diante do Cabralismo e seu "regime da matéria, ele, assim como Herculano, acreditavam numa possível mudança da sociedade portuguesa através de um planejamento educacional

\footnotetext{
${ }^{166}$ Ibidem, p. 146.

${ }^{167}$ Ibidem, p.147.

${ }^{168}$ Ibidem, p. 227.
} 
amplo, que abarcasse a produção jornalística, a renovação literária, a reeducação dos gostos e da mentalidade e a educação formal.

Assim como o Romantismo de um modo geral, o trabalho dos românticos portugueses estava voltado para uma perspectiva política, imbuída de leituras e interpretações próprias sobre os problemas da realidade portuguesa. Garrett e Herculano arquitetaram projetos "salvacionistas", de ordem cultural, econômica e política, carregados de uma perspectiva romântica, mas assim como as gerações anteriores (os intelectuais ilustrados portugueses e os liberais constitucionalistas), também analisaram os problemas a partir duma metodologia empírica e historicamente fundamentada.

"Quando, diante das Cortes Constituintes de 1821, reunidas para regenerar a Pátria, Manuel Fernandes Tomás, no relatório que já estudamos, verifica que "hoje só nos resta a lembrança do que fomos"- quando, por esse modo, explicita crença tão generalizadamente intuída, vem à superfície uma das constantes de toda a nossa ideologia liberal, nesta radicando, sem dúvida alguma, a teoria decadentista portuguesa contemporânea, cuja expressão mais idônea é a filosofia implícita na História de Portugal de Herculano, que por seu turno, alimentará ainda as reflexões, sobre o mesmo tema, de um Antero ou de um Oliveira Martins, e continuará a estar presente, conquanto mais difusamente, na generosa névoa republicana”"169

Apontados como "iluministas românticos" ${ }^{170}$, os grandes expoentes da primeira geração romântica tinham um plano pedagógico para Portugal que acabaria com a insuficiência cultural da nação, postura, sem sombra de dúvida, própria das Luzes. " $O$ plano dos iluministas românticos pretendeu, na intenção, ampliar o conceito de democratização cultural já preconizado no século XVIII nos programas de reforma (sobretudo de Verney e Ribeiro Sanches)" "171. Assim como os reformistas ilustrados, os novos reformistas queriam continuar o combate contra os indivíduos ineptos politicamente e promover uma valorização de uma "aristocracia do talento e do espírito" ${ }^{172}$.

"Daí que, em continuidade com algumas propostas já vindas do iluminismo, ganhassem força prioritária os projectos tendestes a lançar as bases de uma educação verdadeira, ente nacional, em que o ensino da história, em articulação com o da

\footnotetext{
169 SERRÃO, Joel. Op.cit. p. 61.

${ }^{170}$ Termo de Alberto Ferreira.

${ }^{171}$ FERREIRA, Alberto. Op.cit.p. 38.

${ }^{172}$ Palavras de Herculano retiradas do Diário do Governo de 1838, e inicialmente citadas por Alberto Ferreira. Idem, p. 38.
} 
literatura e o da moral, desempenharia um papel decisivo na formação das novas gerações" $" 173$.

Os novos reformistas queriam um modelo educacional voltado ao progresso da sociabilidade moral (representada por uma nação conhecedora de si mesma e ligada por laços afetivos, promovedora da revalorização das relações qualitativas entre os homens), das noções de bem público e dum espírito livre, sem as intervenções de um modelo político absolutista.

"O intelectual romântico, na linha de desenvolvimento de uma posição que já vinha do século XVIII, sentiu-se participante de uma "república das letras", construída por todos aqueles que, tendo ascendido por mérito (e não por nascimento ou riqueza) ao papel de mediadores da verdade, deviam irradiar uma nova cultura, tendo em vista reformar a "alma nacional". Por isso, principalmente na primeira fase do romantismo, aquele se afirmou como um educador e defendeu que só uma profunda revolução cultural poderia ajudar à construção de uma nova sociedade em que os indivíduos, compreendendo-se como entidades unívocas, interiorizassem, igualmente, imperativos sociabilitários ${ }^{\prime 174}$

Podemos verificar esta idéia no trabalho de Almeida Garrett voltado, exclusivamente, para a educação, o ensaio Da Educação (1829), que logo na introdução já é categórico: "Eu tenho que nenhuma educação pode ser boa se não for eminentemente nacional" ${ }^{175}$. O elemento nacional, como chave para um verdadeiro ensino é reafirmado nesta sentença: "Pois educar por livros estrangeiros é o mesmo que mandar educar a países estrangeiros (...) é preciso imita-los, mas apropriando-os a nossos costumes e circunstâncias" "176, aqui os costumes (termo já utilizado no período das Luzes e, exemplarmente, por Voltaire) pode ser visto como um desdobramento, uma ampliação, do conhecimento valorizado pela investigação empírica dos reformista ilustrados portugueses. A intenção de reverter a suposta decadência cultural de Portugal, constatada no período de Pombal, continua sendo combatida pelos novos reformistas ou "ilustrados românticos".

\footnotetext{
${ }^{173}$ CATROGA, Fernando. "Capítulo 2 - Alexandre Herculano e o Historicismo Romântico" In: CATROGA, Fernando; MENDES, José Maria Amado \& TORGAL, Luís Reis. História da História em Portugal (Séculos XIX-XX) - Volume I (A História através da História). Coimbra: Temas e Debates Atividades Editoriais Lda, 1998, p. 45.

${ }^{174}$ Idem, 45.

175 GARRETT, Almeida. “Da Educação”. In:Obras de Almeida Garrett - vol.1. Porto: Lello \& Irmão Editores, 1963, p.677.

${ }^{176}$ Idem, p.678.
} 
O conhecimento histórico ${ }^{177}$ será escolhido para empreender uma educação voltada à moral e à ética do cidadão. Logo no início do processo educacional, o ensino deveria voltar-se para a formação de um futuro homem público ou daquele que soubesse valorizar seu passado por meio dum desvendar dos significados dos costumes nacionais, deste modo o ensino da história despontaria como fundamental para uma completa formação do cidadão.

Almeida Garrett apontou as qualidades do primeiro livro a ser oferecido para as crianças: "Um bom livro que contivesse - primeiro, histórias verdadeiras (anteriormente, traçou em seu ensaio uma crítica contra os livros de fábulas), bem escolhidas e tiradas das antigas e modernas crônicas - segundo, vidas de homens célebres, uma espécie de Valério Machado e Plutarco da mocidade, em que se achassem, não Gregos e Romanos somente, mas varões ilustres de todos os povos e principalmente nosso (...) ${ }^{\prime 178}$. Os costumes nacionais passariam a ser, inicialmente conhecidos, através da empatia com "heróis" da nação.

“(...) Garrett estabelecera em doutrina e na prática o que havia de constituir a estética literária do primeiro romantismo português e suas seqüelas: estudo do Portugal medievo, onde, segundo ele e Herculano, existia em potência o autêntico Portugal com as suas vigorosas forças criadoras, que só o povo guardava ainda nos seus costumes, crenças e tradições" 179

O passado, tanto para Garrett quanto para Herculano, era visto como elemento essencial para a superação do atraso cultural e decadência econômica de Portugal. Porque servia como verdadeiro "espelho em que nos estudamos a nós, estudando os nossos semelhantes, e fielmente nos retrata a fealdade de nossos vícios e a beleza de nossas boas qualidades" ${ }^{180}$. Os problemas do presente só seriam resolvidos por aqueles capazes de “dissecar todos esses cadáveres históricos e anatomizar o coração humano" ${ }^{181}$, deste modo, analisando o indivíduo privilegiado, suas paixões e ações, que o homem compreenderia melhor suas instituições.

\footnotetext{
177 "Nenhuma época anterior teve a consciência de ser herdeira do passado quanto a romântica e, embora o romântico se deixe arrastar pelo temor em relação ao presente, foi ele o primeiro a examinar de frente seu tempo: pela primeira vez, estabeleceu-se uma ligação entre o passado e o presente, a fim de encontrarem explicações para o mundo circundante" VECHI, Carlos Alberto. "A estética romântica". In: MOISÉS, Massaud (org.). A Literatura Portuguesa em Perspectiva - Volume III

(Romantismo/Realismo). São Paulo: Editora Atlas S.A, 1994, p.27.

${ }^{178}$ GARRETT, Almeida. Op.cit. p. 731.

${ }^{179}$ CHAVES, Castelo Branco. O romance histórico no romantismo português. Lisboa: Editora Bertrand, Coleção Biblioteca Breve, 1979, p.14.

${ }^{180}$ Idem, p. 741.

${ }^{181}$ Ibidem, p.745.
} 


\subsubsection{Alexandre Herculano: sua formação e suas interpretações românticas:}

Alexandre Herculano de Carvalho e Araújo nasceu em 28 de março de 1810 e faleceu em 13 de setembro de 1877. Filho de Teodoro Cândido de Araújo, recebedor da Junta dos Juros (depois Junta do Crédito Público) e de Maria do Carmo de São Boaventura.

“A família da Herculano pertencia a uma burguesia estável e mesmo próspera, ao menos até a cegueira do pai, (...) A formação na casa era, pois, acentuadamente cristã e católica, de matriz liberal, (...)" ${ }^{\prime 82}$.

A educação de Herculano foi marcada, desde o início, por uma forte religiosidade e pela iniciação no pensamento científico e humanístico pelos Oratorianos ${ }^{183}$, características que foram decisivas para Herculano desenvolver sua crítica social, cultural e histórica, apesar da pouca idade com que frequentou o Colégio das Necessidades $^{184}$.

“Do ponto de vista de sua formação intelectual, em carta ao Duque da Palmela, Herculano atribui a esses religiosos a adesão firme que sempre dará à lógica, a ponto de considerar a sua constante e habilitada utilização, em todos os campos, como uma peculiaridade do seu próprio espírito (...)”185.

Tanto a religiosidade, realçada por uma formação intelectual oriunda de leituras de escritores românticos e do estudo da Bíblia pelos Oratorianos, quanto um pensamento herdeiro da ilustração, proveniente do estudo da lógica, podem ser claramente distinguíveis nos diversos escritos de Herculano ${ }^{186}$.

\footnotetext{
${ }^{182}$ FEDELI, Maria Ivone Pereira de Miranda. O Poeta Pedagogo - Elementos de um projeto de pedagogia social na poesia de Alexandre Herculano. Dissertação de Mestrado apresentada ao Departamento de Letras Clássicas e Vernáculas da FFLCH/USP, São Paulo, 2002, p. 27.

183 "A educação literária de Herculano iniciou-se com o estudo do latim e latinidade nas aulas dos padres congregados de S.Filipe de Nery, no Convento de Nossa Senhora das Necessidades”. RIBEIRO, Carlos Portugal. Alexandre Herculano - A sua vida e a sua obra (1810-1877). Lisboa: Tip. da Empresa Nacional de Publicidade, 1933, p. 30.

184 “O futuro historiador foi aluno dos Padres de S.Filipe Nery até aos quatorze anos” Idem, p.34.

${ }^{185}$ FEDELI, Maria Ivone Pereira de Miranda. Op.cit. p.34.

186 “Terminadas as humanidades, matriculou-se no curso matemático da Academia Real de Marinha, que só frequentou um ano, entrando depois como aluno para a Aula de Comércio. Destinava-se, talvez, à Universidade, ao concluir os estudos humanísticos, mas, dificuldades pecuniárias, provenientes da cegueira e aposentadoria do pai, cortaram a carreira do moço estudante, não lhe permitindo seguir um
} 
Além da educação recebida pelos Oratorianos, não podemos esquecer da sua estada no círculo de amigos da Marquesa de Alorna, que lhe deu embasamento para seus estudos românticos, tanto no campo literário quanto histórico.

“É, certamente, nessa fase que Herculano começa a formar suas convicções sobre a missão social do Poeta e do Literato, conviç̧ões que o seu contato com o Romantismo alemão e francês virá reforçar e precisar, e às quais ele aderirá com grande força. Prova disso é que fará de sua arte um "sacerdócio moral", que lhe exigirá até mesmo o celibato"187.

Foi nessas reuniões literárias que Herculano começou um estudo sistemático de línguas modernas, entre elas, o francês, o inglês, o italiano e o alemão. Estudo que foi importante para que Herculano entrasse em contato com as diversas produções literárias da Europa e lhe encorajasse para que fizesse suas primeiras incursões no mundo das letras. Além disso, dedicava-se a aulas de paleografia na Torre do Tombo, necessárias para o contato e a leitura de diversos documentos históricos ${ }^{188}$.

“O estudo de paleografia denunciava, quiçá, no adolescente, às voltas ainda com as disciplinas comerciais, a inclinação do seu espírito para os estudos históricos, de cujos progressos na Alemanha ficaria depois ao par, graças ao conhecimento que adquirira do idioma alemão" 189 .

Além de uma juventude dedicada ao estudo, Herculano desenvolveu uma militância política, ainda hoje pouco estudada, que lhe proporcionou o exílio em 1831 devido ao seu envolvimento com a revolta do $4^{\circ}$ Regimento de Infantaria contra o absolutismo miguelista.

"Envolvido na conspiração e na revolta contra o absolutismo miguelista, Herculano foi obrigado a emigrar, em 1831, para a Inglaterra (Plymouth) passando depois a França, e dali à Ilha Terceira de onde parte integrado no Batalhão de Voluntários Académicos, para participar no cerco do Porto em 1832",190.

curso superior" FRIEIRO, Eduardo. "Prefácio". In: HERCULANO, Alexandre. Lendas e Narrativas. São Paulo: W.M. Jackson Inc. Editores, s/d, p. VI.

${ }_{187}$ FEDELI, Maria Ivone Pereira de Miranda. Op.cit. p. 49.

188 "Em 1830 frequentou na Torre do Tombo a aula de paleographia". FIGUEIREDO, Fidelino de.

História da Litteratura Romântica (1825-1870). Lisboa: Livraria Clássica Editora, 1923, p. 84.

${ }^{189}$ FRIEIRO, Eduardo. Op.cit. p. VII.

${ }^{190}$ PEREIRA, B.Capelo. verbete "HERCULANO" In: BUESCU, Helena Carvalhão (Coord.) Dicionário do romantismo literário português. Lisboa: Editorial Caminho, 1977, p. 223. 
A experiência do exílio foi importante para o amadurecimento de Herculano como intelectual português e, de certa maneira, europeu ${ }^{191}$. Foi na Inglaterra que, de acordo com Vitorino Nemésio, tomou contato com o pensamento político inglês ${ }^{192}$. No seu importante artigo "Qual é o estado da nossa litteratura? Qual é o trilho que ella hoje tem a seguir?", publicados em 1834, já na volta do exílio, na revista Repositório Literário, Herculano cita os nomes de Mackintosh, Burdet, Edmund Burke, Sheridan, Canning e Fox, figuras conhecidas no Parlamento inglês.

Além do pensamento político, Herculano ocupou seu tempo em Plymouth com leituras de Shakespeare ${ }^{193}$, capitaneado por pré-românticos e românticos, Young ${ }^{194}$ e Macpherson ${ }^{195}$, autores definidores de temas caros ao imaginário romântico: subjetivismo da natureza, mistério da noite e o "espírito popular" engendrado no folclore nacional.

"Herculano, num artigo do Panorama (II, 1838, p.176), “A Torre Maravilhosa”, diz que "o que só nos falta é um Tegner ou Macpherson, que as [lendas] ligue e enfeite com modernos adornos"; e, $n$ - “Os Escocezes”, aflora o problema da ancianidade dos cantos ossianescos, dizendo que a música escocesa "dá uma idéia do canto com o qual podemos crer que Ossian e os bardos entoavam os seus poemas"196.

A literatura romântica inglesa, que foi fortemente assimilada por Herculano, dentro de suas temáticas, estéticas, historicistas e até políticas, dialogou fortemente com a literatura romântica alemã ${ }^{197}$, sendo que ambas exerceram um importante cabedal de referências para o pensamento romântico de Herculano e também de Garrett.

“Aqui, fiquemos com esta noção: que a leitura dos Thompson, dos Lewis, dos Spenser, dos Crabbe, confirmava os românticos portugueses na necessidade de achar, ou até de inventar, uma massa de tradições poéticas misteriosas que barrassem de vez. os caminhos à mole mitológica dos árcades e trouxessem à poesia portuguesa um forte

\footnotetext{
191 "Herculano era um intelectual português de cultura européia” (...) “(...) não foi também por acaso que a sua maneira de encarar os estudos históricos tem profundas analogias com a de outros historiadores da época”. CARVALHO, Joaquim Barradas de. As idéias políticas e sociais de Alexandre Herculano. Lisboa: Seara Nova, 1971, pp. 25 e 26.

192 NEMÉSIO, Vitorino. A Mocidade de Herculano até a volta do exílio (1810-1832). Lisboa: Livraria Bertrand, Volume II, 1934, p. 89.

193 "De resto, Shakespeare ocorreu-lhe à pena sempre incidentemente; às vezes, mesmo, com citas que são do acervo trivial (...). Mas não há dúvida que a obra do inglês ficou para ele o símbolo da vida em intensidade, do energético e do dramático (...)” Idem, p.97.

194 “Outras vezes, eram os elfos e gnomos da poesia inglêsa que, pelo canal de Young, davam bitola ao fantástico. E Shakespeare reforçava Young, convertendo-se ao romantismo” Ibidem, p.98.

195 “Mas um poeta inglês houve, que, pelo seu sedutor desdobramento em realidade e mito, - Macpherson - Ossian, - feiru particularmente a atenção dos românticos portugueses (...)” Ibidem, p. 103.

${ }^{196}$ Ibidem, p. 103.

${ }^{197}$ Referência que será, posteriormente, analisada no presente trabalho.
} 
sabor nacional. (...). Herculano bebia entusiasticamente nesta literatura de baladas ${ }^{\prime 198 .}$.

Depois do exílio na Inglaterra, Herculano foi para a França. País que, segundo Vitorino Nemésio, Herculano achou a vivência mais agradável e menos "dolorosa" que a experiência inglesa, talvez, devido à familiaridade com as idéias francesas, que circulavam em Portugal há bastante tempo ${ }^{199}$, e com a presença histórica francesa, quase mitológica, dentro do imaginário romântico.

Situação relatada por Herculano no "De Jersey a Granville", escrito de 1837, que diz: "Abandonamos, enfim, o solo d'Inglaterra. (...). Do outro lado estendia-se o mar, chão e espelhado, que se interpunha entre nós e a França; entre nós e esse país, que, para a mocidade das nações ocidentais da Europa, é como uma segunda pátria; porque lá está o centro das idéias que hoje agitam os espíritos, tanto no que respeita às questões sociais, como no que interessa à ciência e à literatura; porque lá vivem os escritores que melhor conhecemos; que, até, amamos como se foram nossos: país, a cujos hábitos, tradições, sucessos e glórias nos têm associado os seus livros, sem sentirmos, sem, talvez, o querermos. Ao aproximarmo-nos da França, o coração não bate violento, não se derramam lágrimas, como ao avistar a terra em que nascemos; mas o ânimo desafoga-se e abre-se à esperança; vamos tratar homens que nunca vimos, mas com quem de largo tempo vivemos pela íntimas relações dos afectos e da inteligência",200

Assim como na Inglaterra, Herculano aproveitou sua estadia na França para ampliar suas leituras e sua influência cultural, e assumir, posteriormente, uma "missão cultural" no regresso à pátria. Autores franceses como Victor Cousin, Thierry, Guizot, Victor Hugo, Lamennais, Lamartine, Vigny e Chateaubriand ${ }^{201}$ foram, provavelmente, lidos e, claramente, absorvidos nas idéias e nas obras de Herculano.

É importante frisar a mútua influência dos autores românticos, em seus temas e suas bases teóricas. Desse modo, Herculano quando lia um texto romântico,

\footnotetext{
${ }^{198}$ NEMÉSIO, Vitorino. Op.cit. p. 106.

199 “Assim, a sedução da França exercia-se em Portugal sôbre vasto terreno e em larga escala, por meio de órgãos livrescos e de contactos directos, através de informações noticiosas e até mediante o choque das divisões napoleônicas, que, agravando o pundonor nacional, o compensavam com a noção, ainda pouco clara, germinal mas poderosa, de uma cidadania superior aos limites tradicionais” Idem, p. 151. ${ }^{200}$ HERCULANO, Alexandre. "De Jersey a Granville". In: HERCULANO, Alexandre. Lendas e Narrativas. São Paulo: W.M.Jackson Inc. Editores, Prefácio de Eduardo Frieiro, s/d, p. 412. 201 “Como Chateaubriand e Lamartine, ele pretendia aliar o catolicismo com as idéias progressivas do tempo e mostrar que a tradição não é incompatível com a liberdade. $O$ autor de Eurico era estruturamente um romântico”. RIBEIRO, Carlos Portugal. Op.cit. p. 245.
} 
automaticamente, deixava se influenciar pelas idéias de outras bases românticas nacionais.

Após a volta do exílio e o fim da guerra civil, Herculano dedicou-se ao trabalho de bibliotecário, de jornalista e de escritor, assumindo uma posição de destaque dentro do pensamento romântico em Portugal e como figura pública.

Do mesmo modo que a Ilustração portuguesa, os românticos liberais, Garrett e Herculano, pensaram caminhos e alternativas para superar o atraso cultural de Portugal. Herculano, através de uma ampla produção de artigos, romances históricos e obras historiográficas, que começaram a ser escritos mais sistematicamente após sua experiência como exilado e soldado de D.Pedro IV, passou a refletir sobre a condição histórica da sociedade portuguesa e a revelar, o que para ele, eram os males dessa desgastada sociedade.

“O seu projecto ético-estético busca realizar-se em todos os domínios e sob múltiplos modos possíveis: do empenhamento como jovem revolucionário nas lutas liberais à intervenção cívica e política, vigorosa e muitas vezes polémica: das suas imensas leituras à crítica literária, da elaboração de uma poética à escrita da sua obra poética e ficcional; da investigação e recolha paciente e laboriosa das fontes da História de Portugal à escrita inovadora dessa História"202.

O pensamento ético-estético de Herculano está fragmentado em diversas obras, mas é em seus artigos "Qual é o estado da nossa literatura? Qual é o trilho que ela hoje deve seguir?", de 1834, e "Poesia (Imitação - Bello - Unidade)", de 1835, que deixou esboçado, com mais detalhes, suas principais idéias acerca do papel e dos significados da arte e da literatura romântica dentro da sociedade.

Nesses artigos, Herculano destaca a "decadência cultural" portuguesa, a importância de se construir uma literatura nacional, da necessidade de estabelecer um diálogo com outras literaturas, principalmente com a alemã, e do papel "sagrado" do poeta. Ou seja, Herculano defende concepções e conceitos da teoria literária romântica, e nessa crítica lembra as observações de Garrett no "Bosquejo da História da Poesia e Língua Portuguesa", mas vai além, quando se classifica como romântico.

Contra a pura imitação do gosto clássico, Herculano argumenta: “mas, ou o bello, objecto da poesia, seja inteiramente resultado das relações das nossas faculdades

${ }^{202}$ PEREIRA, B. Capelo. Op.cit. p. 222. 
intellectuaes entre si, ou das d'estas faculdades com o mundo objectivo, ou, finalmente, resida neste, é sempre a alma do homem quem o sente e goza" ${ }^{203}$.

Dentro desse artigo, e nos demais escritos de Herculano, a figura do "gênio", como homem sensível que capta a "beleza" transcendental e a configura na obra de arte, ganha importante relevo. O "gênio", além do papel de "tradutor do transcendente", ficaria responsável por captar o "espírito" ou, também chamado de, a verdadeira “índole” de seu povo, e revelá-lo aos demais ${ }^{204}$.

“O poeta é um intérprete dessa idéia geral e do mundo ideal, um profeta que revela o sentido transcendente que as formas ocultam e manifestam. Mas este idealismo não exclui um forte sentido do real e do social, pelo contrário, implica-o. É pela observação que se capta o transcendente na sua manifestação visível, é através das formas materiais que o escritor o pode dar a ver e estas devem ser bem conhecidas" ${ }^{205}$.

O transcendente, denominado por Herculano também como "unidade", deveria sempre estar contido na obra artística, mas redefinido pela subjetividade do artista, ou "gênio", ou "profeta"206.

"A justiça pede que digamos que uma grande parte dos preceitos dos antigos foram deduzidos do principio da unidade, d'esse principio que reside em nossa alma e que, emquanto existirmos sobre a terra, representa para nós o absoluto ao qual nos faz. constantemente tender a consciencia da immortalidade; mas a applicação d'este principio foi em nosso entender muitas vezes errada ou exaggerada,207

Herculano pontua a necessidade de estudar tanto os antigos, Homero, Aristóteles e Virgílio, quanto os modernos, Camões, Torquato Tasso, Klopstock e Chateaubriand, e pede para o artista ir além da simples imitação da natureza e da busca da verossimilhança, que busque o belo na individualidade e na unidade, no particular e no universal $^{208}$.

\footnotetext{
${ }^{203}$ HERCULANO, Alexandre. "Poesia (Imitação - Bello - Unidade)" publicado em 1835 na revista Repositório Literário. In: HERCULANO, Alexandre. Opúsculos - Tomo IX. Lisboa: Biblioteca Nacional de Lisboa, Typografia da Antiga Casa Bertrand, 1909, p. 26.

204 “(...) o seu conceito de nacionalidade literária que incorpora a noção de génio colectivo e popular e a valorização da tradição; ou ainda a exaltação da individualidade e a liberdade como condição do acto criador. É, pois, como síntese de diversas matrizes e de vários influxos que deve ser entendido o romantismo herculaniano e a sua completa coerência” PEREIRA, B. Capelo. Op.cit. p. 225. ${ }^{205}$ Idem, p. 225.

206 "O artista genial não se prende às aparências, mas através delas atinge as coisas em si, as Idéias presentes na mente divina, revelando-as na obra de arte como testemunho do Absoluto" BORNHEIM, Gerd. "Filosofia do Romantismo". In: GUINSBURG, J. (Org.). O Romantismo. São Paulo: Editora Perspectiva, 1978, p. 104.

${ }^{207}$ HERCULANO, Alexandre. Op.cit. p. 28.

208 "O Universo não é senão a repetição indefinida da individualidade" Ibidem, p. 36.
} 
"A condição, pois, do bello é a concordância da variedade da idéa particular com a unidade geral: condição que é por tanto necessaria em todos os juízos acêrca do bello.

Mas existindo essa harmonia no jogo das faculdades e requerendo-se para ella a unidade, esta será subjectivamente absoluta, e tudo o que na idéa particular do objecto não estiver em relação com ella nunca poderá ser julgado bello"209.

No bojo dessas considerações, podemos dizer que Herculano claramente opta por uma estética romântica ${ }^{210}$, dando mostras de conhecer os temas e conceitos, pelo menos na forma de idéias sem autoria definitiva que circulavam nos meios cultos europeus, do Romantismo.

"O primeiro que disse: "em tudo está tudo" teve uma destas revelações da imaginação pura, revelação completa do ideal, que não é mais do que a fusão da variedade absoluta e infinita na infinita e absoluta unidade. "211

Fazendo apologia de uma literatura nacional e de um subjetivismo artístico em sintonia com a busca por uma idéia de Absoluto, Herculano definiu-se como romântico e estruturador do movimento em Portugal ${ }^{212}$.

"Diremos sómente que somos romanticos, querendo que os portugueses voltem a uma literatura sua, sem comtudo deixar de admirar os monumentos da grega e da romana; que amem a patria mesmo em poesia: que aproveitem os nossos tempos históricos, os quaes o Christianismo com sua doçura, e com seu enthusiasmo e o caracter generoso e valente desses homens livres do norte, que esmagaram o vil imperio de Constantino, tornaram mais bellos que os dos antigos: que desterrem de

\footnotetext{
${ }^{209}$ Ibidem, p.50.

${ }^{210}$ Estética romântica muito devedora dos temas e conceitos arquitetados, no seu maior poder crítico, pelo Romantismo alemão. "Porque, antes de mais nada, o Romantismo alemão é o único que se estrutura como movimento, conscientemente, a partir de uma posição filosófica, o que vai garantir à filosofia um destaque singular dentro do panorama romântico geral”. Sendo que a base teórica estética defendida pelos românticos alemães guardava muitas semelhanças com o pensamento de Herculano sobre a arte. "Toda realidade constitui uma unidade fundamental: a natureza é espírito visível e o espírito é natureza invisível, e isso nos é revelado abstratamente pela filosofia e concretamente pela arte" BORNHEIM, Gerd. "Filosofia do Romantismo". In: GUINSBURG, J. (Org.). O Romantismo. São Paulo: Editora Perspectiva, 1978, pp. 77 e 103.

${ }^{211}$ HERCULANO, Alexandre. “O Pároco da Aldeia”. In: Lendas e Narrativas. Op.cit. p.361.

212 "Embora articulando o belo e o bom, afirma a total independência do juízo estético relativamente ao juízo moral e ao juízo lógico, num idealismo estético que lê Kant, mas o lê necessariamente com um olhar romântico.” PEREIRA, B. Capelo. Op.cit. p. 225. “Certas coincidências de expressão parecem mostrar-nos que Herculano leu a Crítica do Juízo, ou parte dela. Mas verifica-se por outro lado que essa leitura foi engarfada numa síntese filosófica já feita, que não deixou Herculano apreender o que há de essencial no Kantismo. Particularmente parece-me que Herculano caiu na confusão de Madame de Stael assimilando o pensamento de Kant ao idealismo de Platão. Parece-me também que Herculano leu a Crítica do Juízo depois de ter adoptado a interpretação de Madame de Stael, (...)” SARAIVA, António José. Op.cit. p. 153 (Nota 8).
} 
seus cantos esses numes dos gregos, agradaveis para elles, mas ridiculos para nos e as mais das vezes inharmonicos com as nossas idéas moraes: que os substituam por nossa mythologia nacional na poesia narrativa; e pela religião, pela philosophia e pela moral na lyrica" ${ }^{213}$.

Alexandre Herculano, além de seu trabalho com a literatura, desenvolveu uma profícua produção como jornalista e muitas vezes, as questões políticas vividas pelo Portugal liberal acabavam discutidas, também, nas suas obras de cunho mais literário. Esse aspecto de conjunto da obra de Herculano revela uma unidade de temas literáriosfilosóficos e opiniões presentes tanto na obra literária e histórica quanto na obra jornalística, reunida, posteriormente, nos Opúsculos.

“De qualquer face que se olhe, na variedade das suas formas e discursos, sempre a obra herculaniana remete para uma totalidade, sustentada por uma visão arquitectónica que realiza a síntese de vários princípios e fundamentos teóricos e estéticos

Um exemplo desta "comunhão" de temas românticos com questões políticas pode

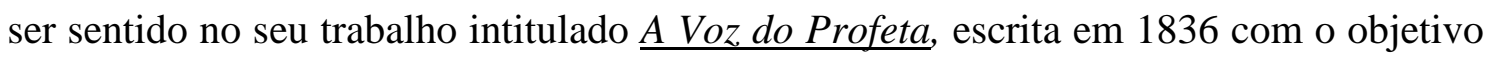
de criticar o movimento setembrista ${ }^{215}$. Obra inspirada em Lamennais e no seu Paroles d'um Croyant, de $1834^{216}$.

Herculano, partidário da Carta Constitucional, liberal e antidemocrático, não poderia tolerar um movimento de acordo com a volta da Constituição de 1822 e com intenções políticas "democráticas" reanimadas pelas massas populares ${ }^{217}$. Como soldado liberal de D.Pedro IV, criador da Carta em 1826, Herculano não poderia, segundo ele, faltar a seu juramento de servir a Carta Constitucional.

\footnotetext{
${ }^{213}$ HERCULANO, Alexandre. Op.cit. p. 69.

${ }^{214}$ PEREIRA, B. Capelo. Op.cit. p. 224.

${ }^{215}$ É interessante notar as conseqüências desse escrito para a vida de Herculano, situação realçada por Fidelino de Figueiredo: "Esse pamphleto, excommunhão fulminada contra o setembrismo, não podia deixar de ser muito bem acceito pela côrte, e D. Fernando, esposo da rainha, a quem Passos Manuel, chefe do setembrismo, humilhára, nomeou-o em 1839 bibliothecario da bibliotheca real da Ajuda, com residencia propria" FIGUEIREDO, Fidelino de. Op.cit. p.85.

216 "Enfim, enquanto as Paroles concluem numa visão resgatadora segundo a qual os tiranos são sacudidos e o povo ascende à liberdade e à luz, "A Voz do Profeta", simetricamente, mostra-nos o povo mergulhado por sua impiedade e por seus vícios, castigado por Deus, no túmulo do aniquilamento. Replicando desta maneira à obra célebre que com tanta retumbância exalta a ideologia democrática, Herculano definia espectacularmente a sua posição" SARAIVA, António José. Herculano e o Liberalismo em Portugal. Lisboa: Livraria Bertrand, 1977, p. 101.

217 "Perante o poder moderador, instituído pela Carta Constitucional, erguiam a soberania popular, reclamando a ampliação dos poderes do Parlamento, o alargamento do sufrágio, a supressão da Câmara dos Pares e a popularização do ensino” SARAIVA, António José. Herculano e o Liberalismo em Portugal. Lisboa: Livraria Bertrand, 1977, p. 98.
} 
“Herculano personifica nos homens do setembrismo o radicalismo irreligioso, anti-tradicionalista e destruidor de monumentos nacionais, contra o qual vinha remando desde 1834 numa campanha que prosseguirá ainda por alguns anos”,218.

No seu primeiro grande escrito, Herculano consegue condensar, como bem apontou António José Saraiva, todas as suas críticas diante de um radicalismo das massas, pintado em tons verdadeiramente apocalípticos, com uma "visão de mundo" tipicamente romântica, denunciando um liberalismo que se aproximava, cada vez mais, de uma proposta materialista, industrializadora e anti-religiosa ${ }^{219}$, que alcançou seu ápice no governo de Costa $\mathrm{Cabral}^{220}$.

Dialogando com o conceito de "gênio" do Romantismo, Herculano assume o papel de "Profeta" anunciador de grandes calamidades públicas que serão trazidas pelo governo setembrista, entre elas a desordem, conduzida pela democracia das massas ${ }^{221}$, e a morte das tradições, principalmente, da religião.

"Era do alto desta pirâmide que o Profeta se admirava olhando o tremedal da ralé e aconselhando D.Maria à resistência, (...)"222.

Mesmo com mudanças "partidárias", como no caso do Cartismo, o autor da "Voz do Profeta, continuou defendendo muitos de seus pontos de vista acerca da ordem política que deveria manter-se em Portugal: uma Monarquia Constitucional de princípios liberais, e afastada dos princípios da "democracia das massas"223.

Para o nosso autor a liberdade, estruturada a partir das necessidades dos indivíduos, era incompatível com a idéia de "democracia das massas", balizada em ideais coletivistas, que para Herculano, eram contrários ao bem-estar dos indivíduos e à

\footnotetext{
${ }^{218}$ Idem, p. 99.

219 "Segundo "A Voz do Profeta”, a plebe materialista odeia raivosamente o passado e procura apagar a inscrição das glórias pátrias; profana com o seu vozear confuso os palácios por onde já ressoaram os sapatos de ferro dos heróis. É este materialismo que, quebrando todos os laços santos da família e da pátria, lançará a nação portuguesa na dissolução moral e no aniquilamento” Ibidem, p. 100.

${ }^{220}$ É importante frisar a mudança de posição política de Herculano em relação ao Cartismo: “(...) a posição política e ideológica do nosso Autor evoluiu de um cartismo extremo (pelo menos na violência verbal) para uma posição moderada, em certos aspectos muito próxima do setembrismo." "E quando, em 1842, apoiado nos regimentos, Costa Cabral ressuscita a Carta, Herculano considera-se definitivamente desligado do partido cartista, (...)” Ibidem, p. 102.

221 "A soberania popular resulta no domínio da força cega sobre a inteligência, na opressão da liberdade” Ibidem, p. 100.

222 Ibidem, p. 101.

223 “(...) Herculano afirmou-se sempre liberal, mas adversário irredutível da democracia, sem que, no entanto, ao menos sob este aspecto, o seu pensamento seja contraditório” CARVALHO, Joaquim Barradas de. As idéias políticas e sociais de Alexandre Herculano. Lisboa: Seara Nova, 1971, p. 27.
} 
justiça social (princípio que deveria estar relacionado às diferenças de talentos, naturais nos indivíduos e não numa "utopia" de uniformização) ${ }^{224}$.

“O liberalismo identifica a soberania popular com o despotismo. Só não seria a soberania popular um despotismo se todos exprimissem a mesma vontade geral, se fosse possível a unanimidade, 225.

Há, dentro das idéias de Herculano, uma valorização da vontade individual (para ele, uma sociedade liberal deve zelar por um livre desenvolvimento do indivíduo questão pedagógica central das políticas públicas), em contraposição a uma vontade geral, que seria sempre imposta por um Estado guiado por uma política tirânica, absolutista ou democrática.

"Mas é sempre o homem essencial que enfrenta, sofre ou age sobre estruturas sociais que o coagem e às quais ele se sobrepõe, pela força dos seus dotes, direitos e responsabilidades, em suma, pela sua vontade, paixão e sentido do justo. Os modos heróico, sofrido ou cobarde, hipócrita ou altaneiro, como o homem se comporta perante a sociedade fazem-na transformar-se: em capacidade, cada vez maior de sucesso na luta pela realização do homem individual face ao colectivo „226

Para Herculano não há vontade geral, mas sim, vontades individuais que não podem ser anuladas diante da política instituída pelo Estado ${ }^{227}$. Deste modo, só com o livre desenvolvimento do cidadão e de suas aspirações pessoais, ou seja, do indivíduo em primeiro lugar, se pode chegar numa hipotética vontade geral da nação.

"Herculano opõe-se à idéia de que o indivíduo é um produto da sociedade. Segundo o pensamento de Herculano e segundo o liberalismo de um modo geral, a democracia (e ainda mais claramente o socialismo) pretende a valorização da sociedade esquecendo o indivíduo, ao passo que o liberalismo tem como objetivo supremo a valorização e o livre desenvolvimento do indivíduo"228.

\footnotetext{
224 “Segundo o liberalismo, na democracia a quantidade prevalece sobre a qualidade, (...). É nesta linha de raciocínio que o liberalismo põe limitações ao sufrágio universal, considerando que nem todos têm condições para o exercer com probidade e independência” Idem, p. 30.

${ }^{225}$ Ibidem, p. 28.

${ }^{226}$ MACEDO, Jorge Borges de. Alexandre Herculano - Polêmica e Mensagem. Portugal: Livraria Bertrand, Prêmio de Ensino Alexandre Herculano 1977/78, 1980, p. 29.

${ }^{227}$ Deste modo cabe formar adequadamente o indivíduo no que diz respeito à moral e à ética. " $O$ indivíduo será aquilo que a sociedade permita que ele seja”. HERCULANO, Alexandre. Citado por CARVALHO, Joaquim Barradas de. Op.cit.p. 61.

${ }^{228}$ CARVALHO, Joaquim Barradas de. Op.cit. p. 37.
} 
Segundo vários autores, entre eles, António José Saraiva, Joaquim Barradas de Carvalho, Oliveira Martins ${ }^{229}$ e B. Capelo Pereira, que se propuseram a investigar o ideário político de Herculano, notaram que há, nesse emaranhado de escritos herculanianos, uma visível influência de um cristianismo, apreendido pela formação familiar e pela ação pedagógica dos oratorianos, e por uma série de leituras de filósofos, historiadores e escritores românticos que forjaram um verdadeiro diálogo de idéias no leitor voraz e arguto observador da realidade que foi Herculano.

Esse fervoroso debate de escritos dificulta, e muito, o estabelecimento de uma linha única de análise no desvendar do pensamento de nosso autor como um todo. Já que Herculano nunca escreveu um documento onde sistematizasse seus princípios de forma coerente, com base nas leituras realizadas. Sempre foram artigos em jornais e periódicos, romances, poesias e obras historiográficas, que se ligam num feixe complexo de idéias.

Herculano quando expõe seus princípios políticos, econômicos, sociais, culturais e históricos, cita o nome de vários autores, entre eles, Schiller, Herder, Goethe, Montesquieu, Gibbon, Niebuhr, Thierry, Guizot, Kant, Cousin e Mouzinho da Silveira. Ou seja, formula uma verdadeira fonte eclética de idéias e concepções que serão utilizadas nas suas obras.

“É portanto natural que Herculano não desconhecesse um Benjamin Constant ou um Royer-Collard" $" 230$.

António José Saraiva destaca a influência de Victor Cousin ${ }^{231}$ em Herculano na fundamentação das suas concepções de "individualismo" e "liberdade". "Em filosofia deparava-se-lhe, com efeito, uma tentativa de conciliação entre aquilo a que Cousin chamava "as duas margens da filosofia”, isto é, o sensualismo oriundo de Locke, (...), e o idealismo alemão de Kant e Fichte, (...)"232.

Victor Cousin, partidário do "espiritualismo" francês, dialogava com as concepções românticas de "particular no universal" e da crença da ação do Absoluto na

\footnotetext{
229 "O kantismo como filosofia, o individualismo como política, o livre-câmbio como economia, eis aí as três fases da doutrina que, por ser um filósofo, Herculano media em todo o seu alcance”. MARTINS, J.P. de Oliveira. Op.cit. Volume II, p. 246.

${ }^{230}$ CARVALHO, Joaquim Barradas de. Op.cit. p. 110.

231 "Contra uns e contra outros o "espiritualismo", inaugurado na cátedra da Sorbonne por RoyerCollard e eloqüentemente desenvolvido por Cousin sob o nome de "eclectismo", afirma a realidade e a autonomia do Eu, e a possibilidade de ele conhecer o real, isto é, o Não Eu. Segundo Cousin, o homem participa da razão universal, ou logos, da qual a razão individual não é mais que um fragmento (...)” Idem, p. 49

${ }^{232}$ SARAIVA, António José. Op.cit. p. 49.
} 
realidade e na história por intermédio do homem, motivos facilmente identificados nos romances históricos de Herculano.

"Por sobre Kant, Locke e Descartes, Cousin vai dar a mão a Platão, de quem se considera seguidor, e afirma que o mundo das idéias está escondido no mundo dos factos, aproximando-se assim, de um ponto de vista caro aos escritores românticos, segundo o qual a natureza não é mais que a expressão visível do absoluto. É esse absoluto, segundo Cousin, que o artista deve procurar dentro das formas variáveis e imperfeitas da natureza. E cerzindo a este fragmento de Platão um fragmento de Hegel, considera a História, desde as formas elementares do mundo inanimado até às realizações mais perfeitas da humanidade, que são os heróis, como o desenvolvimento progressivo da Ideia ou Razão divina. Cada século e cada época encarna uma ideia, ou, melhor, uma fase da Ideia"233.

A existência de uma "vontade individual" atuando na sociedade em detrimento do poderíamos chamar de "vontade geral" 234 , não descarta, para Herculano, a importância de uma instância moral reguladora dos indivíduos em suas ações morais e que garanta a liberdade e a propriedade.

A crença numa religião reformada, nos valores fundamentais do cristianismo, e um amplo projeto pedagógico contribuiriam para a formação de um Estado balizado na "vontade individual" e livraria a sociedade de "uma futura autoridade de um Estado orgânico", como bem pontuou Oliveira Martins. O Estado, para Herculano, só deveria garantir as liberdades individuais e a ordem social ${ }^{235}$.

“A tradição religiosa, ou antes aquela pseudotradição de um catolicismo liberal inventada pelo romantismo, servia, pois, ao filósofo para temperar o seu individualismo, conciliando-o com um resto de autoridade social consagrada nas prerrogativas do trono representativo. De tal modo se combinava o racionalismo com o

\footnotetext{
${ }^{233}$ Idem, p. 49.

234 "Herculano é o legítimo discípulo de Mouzinho, que tanto admirava; e, depois do que dissemos acerca da teoria individualista, ao estudar o primeiro defensor dela entre nós, parece-nos desnecessário entrar em repetições. Já avaliávamos o merecimento, já também vimos as conseqüiências práticas de uma ideia que, suprimindo toda a espécie de autoridade colectiva, resumindo na consciência individual a origem do Direito, funda a sociedade sobre uma nova espécie do antigo pacto dos juristas. Renegando o direito divino dos monarcas, expressão tradicional, renega a soberania popular da democracia, expressão ainda com efeito por definir, ensaio rude, aritmético, tirania brutal do número, império de maiorias ignaras; mas expressão embrionária da futura autoridade orgânica do Estado” MARTINS, J. $\mathrm{P}$ de Oliveira. Op.cit. Volume II, p. 247.

235 "As consciências individuais são valores absolutos que não alienam todos os seus direitos à sociedade. Alienam apenas um mínimo deles, para que seja possível a vida do indivíduo em contato com os outros. Não há vontade geral, há vontades individuais. O objetivo da política é assegurar que todas estas vontades individuais com interesses dissemelhantes vivam lado a lado.” CARVALHO, Joaquim Barradas de. Op.cit. p. 37.
} 
romantismo, e este traço é o que dá a Herculano, ou antes à sua doutrina, um carácter de individualidade original, depois do ensino apenas racionalista de Mouzinho da Silveira"236.

A necessidade de difusão do cristianismo, como fonte de caridade e espiritualização dos indivíduos, é um ponto chave para a compreensão do pensamento romântico de Herculano em luta contra a visão de mundo materialista e utilitarista. Além de força moral e ética, o cristianismo deveria ser visto como um repositório do "espírito do povo", das tradições que acrescentavam uma identidade ao povo português, e por meio de suas festas, cerimônias, hagiografias e rituais, a religião cristã faria seu papel de "reencantadora" do mundo e da realidade.

O estímulo em despertar uma verdadeira religiosidade no povo português e preservar as tradições populares religiosas estava dentro de seu projeto ilustrado/ romântico de renovação cultural para Portugal ${ }^{237}$. Assim como tinha assumido o papel de "profeta" no governo setembrista, Herculano aprofunda ainda mais suas iniciais disposições em encontrar um caminho para reerguer a Nação portuguesa de sua "decadência" generalizada.

António José Saraiva resgata um trecho do escrito intitulado "Cenas de Um Ano da Minha Vida" onde Herculano, na sua crítica corrosiva, aponta os males de um mundo excessivamente materialista e não espiritualizado.

"Pervertido, este século não entende o espírito religioso, e orgulhoso das suas mesquinhas invenções, não entende a traça sublime dos edifícios levantados por mãos dos nossos maiores. Não passará muito que a árida palavra dos ecônomos públicos e alvitristas passará por cima deles, e os reduzirá a cinzas, donde saiam fábricas, e engenhos e obras-primas de artificiosa composição; mas donde não sairá por certo uma palavra de consolo para o desventurado, nem o óbolo para o mendigo, nem o ósculo de paz e a oferta de abrigo para o peregrino. Escogitam-se hoje todos os modos de gozar uma aprazível vida exterior, mas esquecem-se os repouzos e os gozos da vida interior, e a medonha realidade despiu de ilusões o universo" ${ }^{238}$.

\footnotetext{
${ }^{236}$ MARTINS, J.P. de Oliveira. Op.cit. p. 253.

237 "Herculano afirma que o século XVIII, chamando ao tribunal da razão as crenças e superstições da humanidade, e submetendo-as ao debate do livre exame, realizou uma fase necessária e útil no progresso do "gênero humano" - apenas contestando a oportunidade dessa revisão "no século presente". Ao século da incredulidade, sustenta Herculano, deve suceder o século da religiosidade, porque ambos têm o seu papel a desempenhar na marcha do progresso”. SARAIVA, António José. Op.cit. p. 82.

${ }^{238}$ HERCULANO, Alexandre. "Cenas de Um Ano da Minha Vida". In: SARAIVA, António José. Op.cit. pp. 83 e 83 (nota 7).
} 
O projeto de restauração de Portugal por Herculano passava por uma renovação das condições externas e materiais do país (defesa do individualismo, garantia da propriedade, programa de distribuição de terras ${ }^{239}$, condições favoráveis para o trabalhador constituir uma poupança e uma defesa do municipalismo histórico e da agricultura $^{240}$ ) e da "vida interior" (desenvolvimento de uma literatura nacional, resgate de uma consciência histórica e o fomento da educação pública primária e especializada), mas toda essa proposta de melhoria das condições físicas, materiais e educacionais deveriam ser balizadas por uma profunda mudança religiosa.

Segundo Herculano, a ética cristã da caridade e da afetividade entre cristãos deveria ser valorizada e sensibilizada de várias formas entre a população. "É para além da consciência e da razão, para além do homem, num mundo não contingente que tem de se procurar o fundamento da moral ${ }^{, 241}$.

O cristianismo, restituído de sua verdade histórica retida nos ensinamentos dos Evangelhos, sem os preconceitos e relativismos morais dos sacerdotes, mostrar-se-á, para Herculano, puro nas suas mensagens de liberdade, caridade e concórdia ${ }^{242}$.

“Com o sol da liberdade era o próprio cristianismo que renascia na sua pureza por sobre as ruínas do antigo regime e da jerarquia eclesiástica. O soldado liberal deve hastear a cruz sobre o pendão da liberdade e tornar-se um apóstolo do Evangelho no lugar do frade expulso do púlpito"243.

No bojo dessas considerações, podemos dizer que o conto "O Pároco da Aldeia", presente nas Lendas e Narrativas, escritas entre 1839 e 1851, que definiu melhor o

\footnotetext{
239 “O parcelamento da terra é a par do planeamento geral outro meio de aumentar a intensidade da produção. A pequena cultura é mais econômica que a grande e o seu produto bruto é maior que o desta, em virtude de o trabalhador ser simultaneamente o proprietário" SARAIVA, António José. Op.cit. p.191.

240 "Em torno as terra centrou Herculano a quase totalidade dos problemas nacionais. Resumindo o seu pensamento, a riqueza nacional depende da abundância e do planejamento geral da produção agrícola; uma boa estrutura social depende de uma adequada divisão da propriedade; o problema do capital e trabalho resolve-se por leis que facilitem a aquisição de terra pelo lavrador” Idem, p. 189.

${ }^{241}$ SARAIVA, António José. Op.cit. p. 62.

${ }^{242}$ De maneira semelhante, mas de forma não tão intensa, Almeida Garrett vê a importância da restauração de um ideal religioso cristão afastado da influência do Absolutismo. "A religião do Evangelho, da qual disse Rousseau, "que se não fosse divina, merecia sê-lo" é a natural protectora dos direitos do homem, declarativa de sua igualdade, funda-se em sua liberdade, prega, aconselha, ordena o amor da ordem e da justiça. Uma religião que declara e professa ser o Criador o único árbitro e senhor do Universo, todos os homens iguais diante dele, que promete amparo ao fraco e desvalido, castigo ao soberbo e opressor, que declara uma comum origem, uma lei comum, um comum juiz de todos os homens, é a maior e mais certa e mais poderosa base de liberdade que pode entrar na moral pública dos povos (...). Assim a religião cristã, que tanto favorece, que tanto protege a liberdade, que a ensina, que a prega, que a manda guardar, - a religião cristã foi feita o maior e mais poderoso auxiliar dos déspotas." GARRETT, Almeida. "O Pároco da Aldeia”. Op.cit. p. 813.

${ }^{243}$ SARAIVA, António José. Op.cit. p.72.
} 
projeto religioso de Herculano, da religião como foco de caridade, local de afetividade e "reencantamento do mundo".

Logo no Prólogo do autor, Herculano já enfoca a superioridade do cristianismo diante da "filosofia", ou o que ele encara aqui como tal, em relação ao posicionamento do homem diante do mundo. O cristianismo, reinterpretado por uma visão de mundo romântica, mantém o homem num eterno estado de pureza e concórdia. A inocência da mensagem religiosa evita que o homem saia de uma "ignorância" afetiva com a realidade e entre no "lúcido" e angustioso ceticismo da filosofia.

Utilizando-se de imagens da natureza, num típico lugar-comum romântico, Herculano compara a filosofia a um vento destruidor e impiedoso: "Às vezes, na primavera, o vento norte atira-se pelas encostas, tombando dos visos da serra, como se uma inteligência vivesse nele, inteligência de maldade e destruição. (...). Às vezes, como por brinco infernal, o vento finge adormecer um instante, e depois remoinha, e apruma os topos das árvores e as corolas das flores, mas é para logo as vergar com mais força e apupar com o silvo insolente aquela rápida esperança, que se desvaneceu tão breve ${ }^{244}$.

Dialogando com a vertente "irracionalista" do Romantismo ${ }^{245}$, Herculano, leitor de diversos filósofos ${ }^{246}$ e recodificador de diversas idéias da ilustração portuguesa, assume um posicionamento crítico diante dum mundo excessivamente racionalista, utilitário e promovedor do "desencantamento"247. Para Herculano, o homem do campo, que vive a vida em sintonia com a natureza e com um cristianismo "encantado", na pureza de seus

\footnotetext{
${ }^{244}$ HERCULANO, Alexandre. “O Pároco da Aldeia”. Prólogo do Autor. In: Lendas e Narrativas. Op.cit. p. 287.

245 "O irracionalismo era certamente um fenômeno europeu universal, mas por toda parte expressou-se essencialmente como uma forma de emocionalismo e recebeu sua qualidade especial de idealismo e espiritualismo originalmente na Alemanha; só aí se converteria em uma filosofia de desdém pela realidade empírica, baseada no intemporal e no infinito, no eterno e no absoluto”. HAUSER, Arnold. Op.cit. p.60.

246 "Não devemos, porém, esperar de Herculano - que (...) vá mergulhar profundamente em Kant ou em Hegel o seu idealismo, embora às vezes lhe repita certas fórmulas." FEDELI, Maria Ivone Pereira de Miranda. Op.cit. p. 59.

247 "Como a florinha do campo, a alma por onde passou a procela da filosofia, esse turbilhão transitório de doutrinas, de sistemas, de opiniões, de argumentos, pende desanimada e tristonha; e na claridade baça do cepticismo, que torna pesada e fria a atmosfera da inteligência, não pode aquecer-se aos raios esplêndidos do sol de uma crença viva.

Com Kant, o universo é uma dúvida: com Locke, é uma dúvida o nosso espírito: e num destes abismos vêm precipitar-se todas as antologias.

Como a filosofia é triste e árida!

A árvore da ciência, transplantada do Éden, trouxe consigo a dor, a condenação e a morte; mas a sua pior peçonha guardou-se para o presente: foi o cepticismo." HERCULANO, Alexandre. "O Pároco da Aldeia”. Op.cit. p. 288.
} 
rituais e de suas festas, mantém uma transparência de atitudes e pensamentos não mais encontrada no ceticismo e artificialismos dos grandes centros urbanos.

"Feliz a alma vulgar e rude que crê e nem sequer sabe que a dúvida existe no mundo! Está certa de que, além da morte, há vida; conhece as suas condições; conhece-as como lhas ensinaram, como conhece as condições dos corpos. Para ela as noites não têm os pesadelos monstruosos, nem os dias as meditações febris em que o céptico involuntário se debate na orla do possível, que toca por um lado nas solidões do nada, por outro na imensidade de Deus ${ }^{, 248}$.

Em destaque, para além da imagem inocente do homem do campo, "alma vulgar e rude", retumba no mundo a figura do "gênio", do escolhido pela Providência, daquele que consegue captar a presença do Universal no particular, da visível e inteligível beleza da natureza e agraciar o mundo com a poética da sua subjetividade.

"Mas ainda mais feliz a inteligência superior às do vulgo, aquela que a Providência destinou à missão do poeta, nos anos da infância e juventude, antes que o bafo árido da ciência a queimasse passando por cima dela! Nesse espírito e nessa idade, a religião não está só nos preceitos e nos dogmas; está na natureza inteira. A alegria de Deus, o aspirar das fragrâncias celestes, a toada suavíssima dos hinos dos anjos descem a ela nos raios do sol, quando nasce e quando desaparece; tremulam no espelhar-se da lua nas águas; misturam-se no ciclo das árvores; entretecem-se com os mil gemidos da noite; vivem nas afeições domésticas, e santificam o primeiro bater do coração pelo amor. Tudo então é viçoso e puro; porque a alma poética lhe empresta viço e pureza. As harmonias moldadas, na virilidade, pelas leis das línguas e das escolas são apenas um eco frouxo desses cânticos da meninice e da primeira mocidade, que se evaporam sem se escreverem, que são um oceano de delícias inefáveis, em que se embalam molemente a imaginação e o sentir do homem a quem o mundo há-de chamar poeta. Nessa época da vida, ele não abstrai do real para salvar verdadeira e intacta a sua idealidade: faz mais; derrama esta, que é a seiva íntima do seu viver, pelo universo, e converte-o numa coisa formosa, santa, ideal, que o mundo está bem longe de ser" 249 .

No trecho citado acima, Herculano, tece a imagem do homem romântico como o proscrito, o "eterno estrangeiro", aquele que está além dos códigos instituídos pela sociedade. Por ter uma subjetividade em elevado estado, pode se comunicar, numa

\footnotetext{
${ }^{248}$ Idem, p. 289.

${ }^{249}$ Ibidem, p. 290.
} 
linguagem secreta, com o Espírito que habita o todo natural. Essa unidade, ou “interligação subjetiva dos seres", é a verdadeira religião do homem romântico, do "gênio", uma mistura de panteísmo e cristianismo.

Quanto mais intocado pela sociedade esse "poeta natural" fica, mais verdadeiramente sábio ele continua. Para Herculano, a infância e a mocidade do poeta são os símbolos da sabedoria e do real conhecimento do mundo ${ }^{250}$, pois é nessa idade que o poeta sente e se apaixona com todas as forças de sua alma.

"Há quinze ou vinte anos, noite tal como esta tinha para mim um sem-número de misteriosas harmonias, que eu não sabia explicar, mas que sabia sentir. Agora sei dizer-vos o que é a lua, a sua luz refracta, a noite, a viração, o vulto das águas encrespadas, as estrelas e as solidões do espaço; mas o que já não sei é verter as lágrimas de inefável contentamento que, outrora, se me escoavam tépidas pelas faces, contemplando as harmonias materiais e íntimas que vagavam pela atmosfera tranqüila, como ecos longínquos de harpa angélica, rolando de astro em astro, até se derramarem na terra!

Dai-me uma nota só dos cânticos que eu então escutava; dar-vos-ei em troca toda a minha estúpida e inútil ciência!"251.

Após essas considerações do Prólogo, Herculano inicia a narrativa do "Pároco da Aldeia" com o recurso literário da rememoração. Com a lembrança do "velho prior da aldeia", o autor resgata o "espírito" das situações comuns do cotidiano de sua infância e juventude por meio de vários episódios ocorridos num Portugal arcaico e rural ${ }^{252}$.

O pároco da pequena aldeia simboliza todos os aspectos religiosos e morais que Herculano queria preservar na "modernidade capitalista" e, ao mesmo tempo, a conduta nova, de aproximação dos fiéis e do sacrifício em prol do próximo, que os sacerdotes deveriam assumir diante da reconstrução liberal de Portugal.

\footnotetext{
250 "Se o materialismo soubesse que a vida das sumas inteligências é a poesia, e que essa vida segue a ordem inversa do desenvolvimento físico; se conhecesse que a energia íntima tem o seu apogeu nos anos débeis da infância, e começa a desvanecer-se quando os órgãos se fortalecem, ele não teria achado a explicação dos fenômenos nas suas tristes doutrinas. (...). Os olhos da alma vão-se pouco a pouco enevoando no meio das trevas do mundo: nesta atmosfera grosseira e corrupta, ela resfolga a custo, e, com o diminuir dos alentos, diminuem-se-lhe sucessivamente os brios. Cada dia lhe desfolha um afecto, lhe discute uma crença, lhe mata uma esperança, lhe traz um desengano cruel. Entre o espírito e o mundo quebraram-se, um a um, todos os laços.” Ibidem, p. 291.

${ }^{251}$ Ibidem, p.292.

252 "Uma das coisas que, nas recordações da juventude, ainda espiram para mim poesia e saudade é a imagem de um velho prior d'aldeia que conheci na minha meninice" "É que nesse tempo tudo me chegava aos olhos da alma alumiado, risonho, variegado, porque tudo transparecia através de um prisma de sete cores, da inocência singela e crédula da infância, e que hoje tudo me parece, como a folha que caiu da árvore no outono, murcho e desbotado, passando através da atmosfera nevoenta e triste da ciência e do orgulho." Ibidem, pp. 293 e 294.
} 
E dentro dessa nova categorização de uma religião mais caridosa, afetiva e humana, e afastada dos dogmas, que o pároco ganha uma posição de destaque no elo de ligação do povo com o cristianismo.

"No céu profundamente negro não aparece uma estrela: na terra, ao longe, bem ao longe, não se descortina uma luz. A natureza debate-se consigo mesma: tudo dorme, entretanto, nos casais e na aldeia, salvo o velho pároco e a família daquele que em trances mortais espera o representante de Cristo, que lhe traz as derradeiras consolações e esperanças. Entre a filantropia humana e as agonias extremas dos pequenos e humildes a noite e a tempestade ergueram barreira quase insuperável: esta barreira desaparece, porém, diante da caridade que a todos nos ensina o evangelho, $e$ que ao pároco impõem, como dever imprescritível, a sua missão sacerdotal e o seu carácter de pai dos pobres e afligidos ${ }^{, 253}$.

Herculano utiliza-se de uma linguagem coloquial, próxima da popular, para narrar os acontecimentos envolvendo fiéis e o religioso, tecendo um clima de constante envolvimento entre ambas as partes e de confiança do povoado na simples sabedoria do pároco.

"Duas coisas, porém, mais que as práticas e os sermões serviam para engrandecer e glorificar o padre prior, não só diante dos homens, mas também diante de Deus. Era a primeira o incansável zelo com que se aplicava a apaziguar as rixas, a estabelecer a concórdia doméstica, a pregar o trabalho, a guerrear a embriaguez $e$, sobretudo, a santificar pelo casamento as afeições ilícitas: era a segunda o fervor modesto e o inocente luxo com que procurava celebrar as festas religiosas, principalmente a de S.Pantaleão, orago da freguesia (...),254.

O elogia das celebrações das festas religiosas em "modesto" e "inocente luxo" está vinculado à idéia de "reencantamento" do Romantismo. Tanto as festas quanto os rituais religiosos do catolicismo tinham como função, dentro do imaginário romântico de Herculano, estabelecer um vínculo de afeição e comunhão social entre os membros da comunidade e resgatar, constantemente, uma atmosfera sagrada presente no mundo, e negligenciada pelo homem das "grandes cidades" 255.

\footnotetext{
${ }^{253}$ Ibidem, p. 306.

${ }^{254}$ Ibidem, p. 309.

255 “O sentimento poético está mais vivo e puro nas almas habituadas às harmonias campestres do que em nós, os habitantes das grandes cidades: é por isto que os camponeses acendem no estio as fogueiras festivas, usança que, como todos sabem, ofende o nosso profundíssimo e estupidíssimo senso-comum. Eu, por mim, que graças a Deus, não tenho a honra de pertencer à classe desses que lidam, contentes de si, por se bambolearem no vértice da animalidade pura e que se chamam homens da vida positiva, digo
} 
“(...) O catolicismo é jovial: o seu culto, como o vulgo o entende, é ruidoso e risonho e brilhante e atractivo e sociável, e por isso debalde trabalharieis por arrancálo ao povo, que vive e morre no meio do trabalho, dos cuidados, das privações. $O$ domingo, o dia santo, o orago da paróquia são os seus dias de contentamento e repouso. (...). As preces levam, pelo menos, uma vantagem às drogas dos físicos: não custam nada e são mais ricas de esperança, e a esperança é a maior, quase a única virtude dos medicamentos. E depois, as devoções, as promessas geraram as romarias, as festas e logo as feiras e todo esse franco e alegre folgar das multidões, que voltam de lá contentes, sem tédio e sem remorsos, o que nem sempre nos acontece nos nossos prazeres das cidades, a que bem longe estamos de associar nenhum pensamento de Deus ${ }^{256}$.

As festas e os rituais religiosos, resgatados na sua importância por Herculano no "Pároco da Aldeia", configuram-se como símbolos do "espírito do povo", da "índole nacional", assim como as instituições e os costumes nacionais portugueses, e valorizados de igual modo nos estudos e romances históricos de Herculano. Aspecto que aponta a unidade temática da obra de Herculano, preocupada em redefinir um projeto de ampla melhoria para a "decadência cultural" portuguesa e um novo sentido de nacionalidade, assentado no sentimento de afetividade historicamente cultivado pela nação.

“A língua e a religião são as duas cadeias de bronze, que unem, no correr dos tempos, as gerações passadas às presentes, e estes laços, que se prolongam através das eras, são a pátria. A pátria não é a terra; não é o bosque, o rio, o vale, a montanha, a árvore, a bonina: são-no os afectos que esses objectos nos recordam na história da vida: é a oração ensinada a balbuciar por nossa mãe, a língua em que pela primeira vez ela nos disse: - "meu filho!" - A pátria é o crucifixo com que o nosso pai se abraçou moribundo, e com que nós nos abraçaremos, também, antes de ir dormir o grande sono, ao pé do que nos gerou, no cemitério da mesma aldeia em que ele e nós nascemos. A pátria é o complexo de famílias enlaçadas entre si pelas recordações, pelas crenças e, até pelo sangue ${ }^{, 257}$.

Em outro escrito, Herculano deixa clara a importância da mensagem do evangelho, como sinal de liberdade e esclarecimento espiritual, e como manancial para um

que, por mais ardente que vá o estio, amo uma fogueira no arraial em véspera de festa, e aquele estourar e chispar dos foguetes que roçam rápidos pelo manto escuro da noite.” Ibidem, p. 337.

${ }^{256}$ Ibidem, p. 338.

${ }^{257}$ Ibidem, p. 344. 
"reencantamento" da sociedade. "Para o povo ser livre, é necessário que seja religioso e honesto; não que seja crédulo. Para que elle seja religioso e honesto é necessário que conheça as doutrinas do evangelho, que não são mais do que a confirmação divina da moral universal. Em vez de inculcar crendices ao povo, cumpre inculcar-lhe os princípios do christianismo e as conseqüências daquelles princípios: cumpre illustrá-lo, em vez de o conservar na ignorância; fazer-lhe sentir que a força de practicar grandes e nobres sacrifícios, tão recommendados por Jesus, é o caracter que distingue o espírito immortal do homem do instincto que anima as alimárias" ${ }^{258}$.

Além do ideal religioso, presente no "Pároco da Aldeia" e em outros escritos literários, Herculano visualizou também como grande problema do Estado liberal português a sua responsabilidade perante a questão da desigualdade social. No seu ideário político, o dever do Estado é instituir a segurança e a ordem para o cidadão, para isso, esse Estado precisa aprender a lidar com a tortuosa tarefa de manter o equilíbrio entre a desigualdade e a liberdade na sua organização social ${ }^{259}$. Para evitar estas desavenças, Herculano pensou soluções que estivessem aliadas à questão econômica, como a industrialização e a questão agrária.

“Na essência de todas as associações humanas e em todas as épocas e por toda a parte actuam dois princípios: um da ordem moral, íntimo, subjectivo; outro da ordem material, visível, objectivo. É o primeiro o sentimento inato da dignidade e liberdade pessoal; é o segundo o facto constante e indestrutivel da desigualdade entre os homens $" 260$.

A luta entre a liberdade e desigualdade na ordem social configurou-se para Herculano como dado importante para a sua definição de História, no momento só nos interessa pontuar alguns aspectos das soluções pensadas pelo nosso autor para tentar encontrar uma fórmula política que contemplasse o equilíbrio desses dois antagônicos princípios.

No caso de um possível recrudescimento industrial em Portugal, Herculano segue as idéias românticas que desaprovavam a industrialização ${ }^{261}$. Tanto Herculano quanto os

\footnotetext{
${ }^{258}$ HERCULANO, Alexandre. "Solemnia Verba" - “A Batalha de Ourique”. In: HERCULANO, Alexandre. Opúsculos - (Tomo III) - Controvérsias e Estudos Históricos (Tomo I). $7^{\text {a }}$ edição. Portugal: Livraria Bertrand, $1^{\mathrm{a}}$ edição de 1881, p. 109.

259 "Herculano fala-nos da existência de dois princípios que sustentam uma luta eterna: o princípio da liberdade e o princípio da desigualdade” CARVALHO, Joaquim Barradas de. Op.cit. p. 76.

${ }^{260}$ Idem, p.76.

261 "A idéia de Herculano era a de que os melhoramentos materiais só se tornam desejáveis quanto reforçam a estrutura moral e nacional do país, a sua efectiva liberdade. Isto é, desde que não acarretem
} 
outros vultos do Romantismo faziam esses julgamento negativo da "modernidade capitalista" porque miravam suas conseqüências sociais, como a fome das classes trabalhadoras e a opressão do homem diante do capital $^{262}$, aumentando ainda mais a luta entre liberdade e desigualdade.

“Herculano foi impressionado pelo espectáculo da miséria do proletariado. E foi levado a indagar as causas desta miséria. A Inglaterra é o caso para o qual os economistas tinham predominantemente procurado soluções; é em relação a ele que Herculano formula mais claramente uma teoria explicativa da proletarização e do empobrecimento. A causa é dupla: por um lado a má constituição da propriedade rural, por outro lado a introdução do maquinismo na indústria, (...)”263.

A industrialização deveria ser implantada com cautela, respeitando as condições históricas materiais e espirituais das diversas classes sociais, para evitar um ritmo de pauperização acelerado e um quase certo conflito social. Para um processo bem sucedido de industrialização e de ordenamento social, traduzido pelo equilíbrio entre liberdade e desigualdade, o Estado deve adotar uma política de divisão de propriedades e estimular a agricultura.

Assim como os acadêmicos ilustrados, Herculano destaca a importância em se privilegiar os problemas ligados a terra. Propõe como medida necessária uma espécie de reforma agrária ${ }^{264}$, que deste modo colocaria o pequeno proprietário em débito com o Estado liberal, e este passaria a ter uma relação mais afetiva com sua terra e logo iria produzir mais e acabaria se tornando um defensor da ordem pública ${ }^{265}$. Para Herculano

o enfraquecimento moral ou a dependência do indivíduo dentro do Estado”. MACEDO, Jorge Borges de. Op.cit. p. 52.

${ }^{262} \mathrm{O}$ lado negativo da industrialização, tanto suas consequiências sociais quanto morais e éticas, foram registradas, diretamente e indiretamente, por Herculano. Vejamos o que Barradas de Carvalho diz sobre a crítica positiva de Herculano em relação ao socialismo: "Há nela (nas idéias socialistas referentes à Industrialização) indicações de males profundos e dolorosos no corpo social, que fazem estremecer as consciências; que fazem cogitar tristemente os espíritos liberais e sinceros. Estes males profundos e dolorosos são a colisão fatal entre o que possui e o que não possui, entre o Capitalismo e o Trabalho. Herculano diz terem sido estes males imensamente agravados pela industrialização, e vê, por isso, um certo benefício no atraso da indústria em Portugal. Diz que, nos países mais industrializados, a condição das classes pobres é pior do que no nosso, pois nesses países "o capital abusa da sua força imensa para os oprimir””. CARVALHO, Joaquim Barradas de. Op.cit.p. 44.

${ }^{263}$ SARAIVA, António José. Op.cit. p. 202.

264 “Herculano propunha, para além dos melhoramentos materiais, medidas indispensáveis para facilitar as condições de crédito e outros estímulos à produção, que o camponês fosse "ligado" à terra por meio de formas aliciantes de propriedade, pelo desenvolvimento da riqueza real. Entendia ele que a reforma dos contratos de arrendamento, a protecção à propriedade bem administrada, constituíam medidas mais estimulantes para um progresso efectivo e que conduziriam a uma sociedade mais sã". MACEDO, Jorge Borges de. Op.cit. p. 52.

${ }^{265}$ Também diz Garrett: "Que não há maior terror para déspotas, nem melhor presságio de liberdade que o ver uma povo trabalhador, activo e proprietário” GARRETT, Almeida. Op.cit. p. 810. 
"nos países onde a indústria é escassa e predomina a agricultura, o conflito social não se manifesta com aquela agudeza e urgência de resolução. Herculano tem consciência destes fatos e vê, como única saída para a resolução do problema, o predomínio da agricultura, (...), o parcelamento da propriedade e a conseqüente ascensão dos assalariados a pequenos proprietários” 266.

Do mesmo modo que António José Saraiva e Joaquim Barradas de Carvalho, Oliveira Martins também aponta a dependência do projeto político/econômico de Herculano em relação à necessidade do parcelamento de terras em prol do bem-público.

“O livre-câmbio, proclamado como a melhor receita para criar a riqueza, era para Herculano sobretudo a melhor forma de a distribuir. Queria que as leis pulverizassem o solo, no qual não reconhecia outro valor senão o que o trabalho consolidara nele; e esperava que a concorrência, desembaraçada de todas as peias, criasse uma sociedade proudhoniana, em que todos fossem capitalistas $e$ proprietários. ${ }^{, 267}$

O ensino, principalmente no caso de Herculano ${ }^{268}$, o primário ${ }^{269}$ e o público, deveriam estar atrelados a um conhecimento socialmente útil e balizado historicamente, deste modo o cidadão (palavra do vocabulário político europeu, valorizada a partir da Revolução Francesa) ${ }^{270}$ compreenderia melhor e duma maneira mais afetiva o seu passado, ou seja, a origem de suas instituições, de seus "heróis" e do "espírito" constituinte de seu povo.

“(...),Herculano deu uma atenção especial a um terceiro aspecto do ensino público: o aspecto propriamente político. É preciso reeducar politicamente as massas, ou pelo menos educar as novas gerações: assim como a monarquia absoluta moderava os súbditos para a servidão, assim o liberalismo tem de preparar os cidadãos para o exercício dos direitos e deveres civis e políticos" ${ }^{271}$.

\footnotetext{
${ }^{266}$ CARVALHO, Joaquim Barradas de. Op.cit. p.46.

${ }^{267}$ MARTINS, J.P. de Oliveira. Op.cit. Volume II, p. 249.

${ }^{268}$ No período da transição do setembrismo para o cartismo, Herculano é “(...) nomeado membro da comissão parlamentar de instrução pública, juntamente com Silveira Pinto, Lis Teixeira, Tavares de Carvalho, Nazaré, Garrett e Vicente Ferrer Neto de Paiva”. SARAIVA, António José. Op.cit. p. 118. 269 "Em 1835 é organizado o ensino primário, pelo ministro Rodrigo da Fonseca Magalhães”. SARAIVA, Idem, p. 48.

270 "Herculano mostrava-se neste aspecto fiel às directrizes do iluminismo democrático da Rev. Francesa. O ascenso nacional, via-o ele como um facto totalizante; a educação pública não somente abria caminho para um recrutamento das inteligências mais dotadas como era a própria base da morigeração da sociabilidade e da moral” FERREIRA, Alberto. Op.cit. p. 39.

${ }^{271}$ SARAIVA, António José. Op.cit. p. 121.
} 
Assim como todas as faces do projeto liberal de Herculano de reestruturação política, econômica, social e cultural, a mudança da educação, também era visualizada como um planejamento à longo prazo, estruturado em demandas sociais visíveis. Como por exemplo, o aumento do índice de alfabetização, a disseminação de noções de bem público e cidadania e a necessidade de incentivar o estudo de aspectos práticos da realidade material, como o instituído na Escola Politécnica. A Universidade não deveria ser o único alvo a que conduzia a educação liberal e pública em Portugal, uma visualização mais ampla e profunda deveria ser considerada, como exemplo, a educação técnica voltada à produção agrícola ${ }^{272}$.

"De todo este vasto plano de que Herculano apenas esboçou o desenho de uma peça, o ensino primário superior, o carácter mais saliente é a importância dada ao ensino geral ou popular, a expensas do ensino especial ${ }^{273}$. Para Herculano o problema urgente é a elevação do nível cultural das massas; é a sua resolução devem ser aplicados todos os recursos, mesmo sacrificando as escolas especiais. Esta característica distingue o programa de Herculano de outros programas contemporâneos. Para exemplificar: o plano de reforma da Comissão nomeada por decreto de 2 de Novembro de 1833, redigido por Garrett em 1834, ocupa-se principalmente dos estabelecimentos de ensino superior ou especial, mantendo quase intactas as velhas escolas régias, e deixando em claro o problema do ensino geral "274.

Tanto a atividade política, condicionada pelos temas da revolução romântica e pela tradição intelectual ilustrada portuguesa ${ }^{275}$, de Herculano quanto de Garrett foram pensadas sob a égide da criação de um mundo novo, que devia ser construído a partir da

\footnotetext{
272 "Herculano sonhava com uma "república” de cidadãos instruídos, de grande valor nacional, capazes de eleger de entre a "aristocracia da natureza" os seus mais nobres representantes. A reforma de ensino primário por ele preconizada teria de evitar que a instrução básica fosse a mera preparação para o grau superior" FERREIRA, Alberto. Op.cit. p. 41. O projeto pedagógico de Herculano foi do mesmo modo trabalhado por Garrett, balizado numa proposta de esclarecimento da população para a "nova era" liberal que mergulhava Portugal. Vejamos o que escreveu Garrett: "Em tal crise é dever de todo o bom cidadão, de todo o homem verdadeiro amigo de sua pátria juntar quanto cabedal de luzes lhe deu Deus, quanto ganhou em estudo e experiência, e acender seu pequeno farol para o grande luminar da instrução do povo". GARRETT, Almeida. "Portugal na Balança da Europa". In: Op.cit. p. 804.

${ }^{273}$ Escolas instituídas com o objetivo de preparar os estudantes para o ingresso das carreiras acadêmicas da Universidade.

${ }^{274}$ SARAIVA, António José. Op.cit. p. 131.

275 “Daí que, em continuidade com algumas propostas já vindas do iluminismo, ganhassem força prioritária os projectos tendentes a lançar as bases de uma educação verdadeiramente nacional, em que o ensino da história, em articulação com o da literatura e o da moral, desempenharia um papel decisivo na formação das novas gerações”. CATROGA, Fernando. "Alexandre Herculano e o Historicismo Romântico". In: CATROGA, Fernando; MENDES, José Maria Amado \& TORGAL, Luís Reis. História da História em Portugal (Séculos XIX - XX). Volume I (A História através da História). Coimbra: Temas e Debates Atividades Editoriais Lda, 1998, p. 45.
} 
resolução dos problemas do presente, e que para eles quanto para os ilustrados lusitanos, têm a sua origem no passado. Para concluir, podemos dizer que tanto a Ilustração portuguesa quanto o Romantismo da primeira geração serviram de palco para homens preocupados com a ação e a criação de novos significados e rumos para a sociedade lusitana ${ }^{276}$.

\section{O sentido de História para Alexandre Herculano:}

\subsection{O gênio, "o espírito do povo" e o herói: a contribuição alemã:}

O presente início de capítulo tem como proposta fazer uma caracterização das principais reflexões sobre o conceito de História e sua importância como fonte de análise para o pensamento filosófico de alguns autores do "Sturm und Drang", em destaque para Herder, e do idealismo alemão, no caso de Hegel.

Levando em consideração a profundidade e a complexidade das idéias expressas pelos citados autores, o estudo que se seguirá tem a intenção de trabalhar com temas filosóficos e literários pertinentes à dinâmica da dissertação, que é captar o movimento e os significados da reflexão histórica para Alexandre Herculano, tendo em vista seus romances históricos.

Desse modo, a importância do estudo de uma parte das considerações filosóficas deste momento do pensamento alemão, situado no final do século XVIII até a primeira metade do século XIX, está relacionada a uma compreensão maior das idéias de Herculano referentes à estruturação de suas bases teóricas dentro duma perspectiva analítica filosófica romântica ${ }^{277}$.

\footnotetext{
276 "O intelectual romântico, na linha de desenvolvimento de uma posição que já vinha do século XVIII, sentiu-se participante de uma "república das letras", constituída por todos aqueles que, tendo ascendido por mérito (e não por nascimento ou riqueza) ao papel de mediadores da verdade, deviam irradiar uma nova cultura, tendo em vista reformar a "alma nacional". Por isso, principalmente na primeira fase do romantismo, aquele se afirmou como um educador e defendeu que só uma profunda revolução cultural poderia ajudar à construção de uma sociedade em que os indivíduos, compreendendo-se como entidades unívocas, interiorizassem, igualmente, imperativos sociabilitários”. Idem, p.45.

277 "Porque, antes de mais nada, o Romantismo alemão é o único que se estrutura como movimento, conscientemente, a partir de uma posição filosófica, o que vai garantir à filosofia um destaque singular
} 
A sensibilidade romântica alemã, entendida como fruto de um lento processo de amadurecimento das condições históricas, no caso da "dupla Revolução" e da formação de uma consciência nacional, e da continuidade do pensamento ilustrado ${ }^{278}$, assumiu seu papel como movimento cultural, abarcando reflexões estéticas, filosóficas, históricas e políticas, após inúmeras experiências no seu quadro político e intelectual.

No âmbito do pensamento ilustrado, influenciado pelas idéias de Condillac e Hume, uma mudança paradigmática no julgamento da razão começa a ocorrer com as idéias de autores como Kant, Lessing, Winckelmann e Klopstock.

O homem, que fazia parte de uma unidade mecanicista passa a fazer parte de uma unidade orgânica de mundo, onde os corpos possuem uma particularização composta de experiências, sensações e sentimentos submetidos a uma realidade empírica. "Na medida, porém, em que a razão não é considerada valor supremo, realçando-se as forças emocionais e a sensibilidade imponderável do homem, como tais subjetivas e de irredutível variedade, o individualismo tende a tornar-se "organicista": a igualdade essencial, verificável somente através de operações analíticas de abstração, é negada, ou, pelo menos, deixa de ser valorizada em sentido positivo; em contrapartida é acentuada a singularidade da pessoa concreta, inseparável do contexto histórico e nacional. $" 279$.

No bojo destas idéias, uma idéia que vai ganhando força com o passar do século XVIII, é que toda a capacidade mental (o racionalismo) vem da habilidade de abstração a partir das sensações. São as sensações, formadas com base na experiência empírica, que mobilizam a vontade (as paixões) e as ações humanas.

A paixão seria fruto de um desejo muito forte, e este estado levaria, indubitavelmente à ação. Portanto o equilíbrio das ações só poderia ser realizado através da boa disposição das paixões e não da razão, da atividade do raciocínio, já que esta não pode criar vontades ${ }^{280}$. Essas considerações seriam importantes para o advento de novas idéias ligadas a definição de sentimento.

dentro do panorama romântico geral”. “(...) o estudo do lastro romântico que atravessa toda a cultura alemã, (...)”. BORNHEIM, Gerd. "Filosofia do Romantismo”. In: GUINSBURG, J. (Org.). O

Romantismo. São Paulo: Editora Perspectiva, 1978, pp. 77 e 78.

278 “(...) a filosofia inglesa, o Empirismo, é, em não poucos aspectos, todo o contrário do Racionalismo francês, constituindo mesmo forte crítica ao pensamento cartesiano. A confiança na razão passa a esmorecer-se". Idem, p.80.

${ }^{279}$ ROSENFELD. Anatol. Texto e Contexto. São Paulo: Editora Perspectiva, 1973, p. 152.

280 "E ainda em 1746, Vauvenargues (1715-1747) foi mais longe, na Introdução ao Conhecimento do Espírito Humano, causando impacto ao dizer que a essência da alma é constituída pelas paixões, e não 
O conceito de sentimento, com o avanço das idéias de Rousseau e dos sentimentalistas ingleses, como Thomson e Young, afasta-se cada vez mais de um julgamento externo, relacionado às sensações, e adquire uma força de categoria interna, voltada ao espírito. O Eu, nessa nova perspectiva, não seria um acúmulo de sensações, como acreditavam os materialistas, mas algo pré-existente.

Os sentimentos passam a ser relacionados com os desejos (vontades) puros advindos do coração, e deste modo, deveriam ser vividos em sua espontaneidade e força total. Tanto a imaginação quanto as disposições afetivas passam a vigorar objetivamente e subjetivamente dentro do campo de atuação do sentimento.

“O sentimento passa a ser considerado o fator básico na vida individual, pois só nele se traduz a autêntica interioridade do homem. A razão não só é inferior, mas depende do sentimento" 281

A razão, desestruturada em sua força pelos materialistas, passa a ser o resultado do sentimento, que passa a ser a essência da alma, ao lado das paixões. Assim se inaugura uma nova idéia de sabedoria e conhecimento pautada na vivência de um sentimento forte, sincero e profundo (que abarca uma totalidade com o mundo). O cenário das idéias para a eclosão da consciência romântica estava formado.

Podemos dizer que o movimento do "Sturm und Drang", absorvendo a crítica ao racionalismo e essa nova disposição em relação ao sentimento, inaugura uma consciência romântica na Alemanha. "O movimento (...) não se sabia "romântico", embora àquela altura o termo já passasse a ser usado em acepção favorável para caracterizar paisagens agrestes, solitárias, selvagens e melancólicas, (...). Com isto não se pretende negar que há, num sentido geral, certo espírito comum impregnando tanto o "Sturm und Drang", como o romantismo alemão"282.

O movimento do "Strum und Drang” ou “Tempestade e Ímpeto" surgiu como força de continuidade e ruptura no campo das idéias ${ }^{283}$ devido ao desejo de inaugurar uma produção cultural nacional, afastando-se da estética normativa do classicismo francês, ao incentivo da criação subjetiva do artista e à defesa de uma nova visão sobre o conhecimento histórico.

pela razão, uma vez que é a vontade que move as representações e não o contrário”. GRESPAN, Jorge. Op.cit. p.63.

${ }^{281}$ BORNHEIM, Gerd. Op.cit. p. 80.

${ }^{282}$ ROSENFELD, Anatol. Op.cit. pp.148 e 150.

${ }^{283}$ Os "pré-românticos" utilizaram-se de questões do ceticismo iluminista e montaram suas particulares visões de mundo, sendo que alguns deles radicalizaram tanto estas idéias que chegaram à formulação do irracionalismo completo. 
Para caracterizar a importância do movimento, seus principais personagens e temas filosóficos/literários cito as palavras do filósofo Marco Aurélio Werle: "O que marca o ambiente literário alemão da época pode ser compreendido principalmente a partir do que girava em torno do movimento Tempestade e Ímpeto [Sturm und Drang], que eclodiu na Alemanha por volta de 1770 e que consistia numa emancipação das letras nacionais. O título vem de uma peça de F.M.Klinger, intitulada justamente de Sturm und Drang. Embora pareça uma radicalização do espírito da ilustração, esse movimento constitui-se como uma luta contra a ilustração (contra o culto do racionalismo), uma luta de jovens espíritos (Hamann, o mago do norte, Herder, Goethe, Lenz e até Schiller), cujos temas básicos eram: a incompatibilidade entre o indivíduo e a sociedade, o que resultava numa dor do mundo (Weltschmerz); a ênfase no gênio criador que se afirma livre das regras artísticas (deve-se dar vazão aos impulsos naturais e vigorosos); o acentuado individualismo nas artes; o sentimentalismo etc. ${ }^{, 284}$.

A importância do "Sturm und Drang" para o presente estudo está em relacionar os principais temas desse movimento, o irracionalismo, o culto do "gênio", do "espírito do povo" e uma nova sensibilidade de mundo que recai para um sentimentalismo com o desenvolvimento de uma nova consciência sobre a História.

A História, no bojo das considerações iluministas sobre o tema, era vista como um elemento de análise para o pensamento empirista. Desse modo, os estudos históricos passariam a ser valorizados como local de descrições e classificações, citando como exemplo a literatura dos viajantes dos oitocentos, anunciadores da variabilidade das diferenças entre os povos.

Com a constatação de que os diferentes povos não compactuavam com os mesmos costumes $^{285}$, um interesse pela formação histórica desses relativismos tornou-se comum entre os ilustrados, como por exemplo, em Montesquieu e Voltaire. Mas, mesmo percebendo as diferenças entre os povos, traduzida em seus costumes, esses filósofos acreditavam na possibilidade de encontrar uma maneira de educar esses "exóticos" comportamentos e levar uma evolução "civilizatória" a povos "selvagens".

No bojo dessas questões, pode-se dizer que o objetivo último, da perspectiva ilustrada, da constatação e dos estudos dos diferentes povos era tornar os costumes mais

\footnotetext{
${ }^{284}$ WERLE,Marco Aurélio. Trans/Form/Ação, São Paulo, 23: 19-50,200, p.23.

285 “Este é, (a variabilidade/a relatividade dos costumes), em particular, um dos temas preferidos do Iluminismo, que por "costume" entende as práticas sociais que determinam as formas específicas assumidas pelas instituições e pela mentalidade de um povo”. GRESPAN, Jorge. Op.cit. p.56.
} 
universais e racionais, numa tentativa de progresso humano, social e histórico. Havia uma necessidade de uma visão cosmopolita e integradora entre os homens, ou seja, uma medida universal de análise que será contestada pelo "Sturm und Drang".

Os “jovens espíritos" do "Sturm und Drang" como partidários de uma "emancipação do indivíduo por meio do irracionalismo e do sentimento religioso" 286 criticavam a concepção pedagógica da Ilustração em relação aos costumes dos diferentes povos, afirmando que a identidade de um povo se constituía de maneira distinta da racional e que não haveria canais de interligação entre eles.

Para o "Sturm und Drang", o elemento de ligação entre os homens constituintes de um povo estaria balizado em laços afetivos e religiosos, que poderiam ser notados por meio do estudo das manifestações culturais, entre elas a própria linguagem, mais originais e populares. "Com a coletânea "Stimmen der Volker" [Vozes dos povos] (1778-1779), de Herder, instaura-se o interesse em coletar sistematicamente a poesia popular sob a crença de que esta revela, de fato, a alma de um povo, ou seja, aquilo que lhe é realmente peculiar",287.

A peculiaridade dos povos deveria ser refletida sob a luz da vivência afetiva, através duma leitura subjetiva, e religiosa ("panteísta") na busca por um sentido teleológico próprio de cada povo.

Esse sentimento religioso e "panteísta"288 perpassava todo o pensamento do "Sturm und Drang" e da consciência romântica alemã, dando uma forma particular e inconfundível as suas reflexões filosóficas. Não foi diferente com a reflexão sobre a História, que mesmo estudada sob o "espírito" próprio de cada povo, carregava uma finalidade divina de integração com o todo ${ }^{289}$.

Em seu livro Contribuições à História da Religião e Filosofia na Alemanha, o poeta romântico Heinrich Heine aponta uma visão de mundo panteísta presente na base de constituição do pensamento romântico e idealista alemão, como nas obras de Fichte,

\footnotetext{
${ }^{286}$ VOLOBUEF, Karin. Frestas e Arestas - A Prosa de Ficção do Romantismo na Alemanha e no Brasil. São Paulo: Fundação Editora da UNESP (FEU), 1999, p.39.

${ }^{287}$ VOLOBUEF, Karin. Op.cit. p.30.

${ }^{288}$ Entendido no presente trabalho como doutrina religiosa que encara o mundo como sendo um conjunto de manifestações ou emanações divinas.

${ }^{289}$ Em relação às idéias de Herder sobre a História: "Humanitat é a expressão concreta da história humana, que se particulariza no tempo por ações e impulsos” (...) “ A história, nessa medida, constitui-se desses esforços dos homens que, em cada época, em cada lugar, e de modo concreto, buscam tornar-se Humanitat, manifestando-se como povos particulares. Não se trata do progresso do homem em geral, mas da sucessão dos povos cada qual com sua peculiaridade e força. Ao progredir e atingir a plenitude, eles também entram em declínio. O tempo impede a eternização da plenitude” ABRÃO, Bernadette Siqueira (org. e redigido). História da Filosofia. Revisto por Mirtes Ugeda Coscodai. Coleção “Os Pensadores”. São Paulo: Nova Cultural, 1999, p.330.
} 
Goethe e Schelling. Nessa perspectiva panteísta aponta que: "O objetivo mais imediato de todas as nossas novas instituições é, desse modo, a reabilitação da matéria, o restabelecimento de sua dignidade, seu reconhecimento moral, sua santificação religiosa, sua reconciliação com o espírito" ${ }^{290}$.

Podemos perceber este "panteísmo" nas palavras de Hamann: “O mundo inteiro é a linguagem de Deus e a poesia é, portanto, nada mais do que a imitação dessa linguagem" 291 ou nas palavras de Herder: "O homem primitivo pensa por símbolos, alegorias e metáforas, cujas combinações constituem fábulas e mitos. Assim, a poesia não é a imitação da natureza, mas uma imitação do poder criador e nomeador de Deus ${ }^{292}$.

O conceito clássico francês de "universal no particular" havia sido desacreditado, mas um novo conceito de "universal no particular" desta vez integrado numa atitude romântica e panteísta começou a ser formulado no "Sturm und Drang”. Este sentimento romântico de comunicação com o Todo-natural, que aos poucos vai se fundamentando no pensamento alemão, foi muito bem caracterizado pelo filósofo Nicolai Hartmann: “ $A$ natureza exterior não permanece estranha no mundo interior do coração humano. Um sentido novo da verdade surge subitamente no reconhecimento ou pressentimento do próprio ser nas configurações da variedade cósmica. Um novo sentido do belo e uma nova missão da arte cintila nesta revelação do natural”293.

A idéia de Johann Georg Hamann (1730-1788) mais aproveitada na formação de uma literatura romântica, no seu sentido de criação e de arcabouço temático, e na constituição do conceito de "herói romântico" foi a exaltação da figura do gênio. Considerado um indivíduo capaz de absorver as necessidades de seu povo através de seus atos ou de sua criação artística, numa missão de revelação das verdades máximas da comunidade, ou seja, dos elementos indispensáveis para uma nova fase de integração e de comunhão dos valores éticos e morais.

O gênio seria “o louco inspirado", aquele capaz de captar o "espírito do povo" que estaria escondido no artificialismo da sociedade, e revelar aos homens a essência desse espírito e servir de instrumento para que essa essência fosse transcendida pelo

\footnotetext{
${ }^{290}$ HEINE,Heinrich. Contribuições à História da Religião e Filosofia na Alemanha. São Paulo: Iluminuras, 1991, p.66.

${ }^{291}$ WELLEK, René. História da Crítica Moderna ( vol.1 - Século XVIII). Editora Herder, 1967, p.162.

292 Idem, p.169.

${ }^{293}$ HARTMANN, Nicolai. A Filosofia do Idealismo Alemão. Lisboa: Fundação Calouste Gulbenkian, 1983, p.190.
} 
povo. "A sua idéia de gênio é toda sentimento; imaginação, ardor, inspiração, originalidade, poder de criação" 294.

O gênio, elaborado sob essas premissas e como fonte para a criação artística romântica, apresenta uma nova idéia de sabedoria e conhecimento, nos quais o homem "genial" seria capaz de sentir com todas as forças da sua alma, numa comunicação intensa com a natureza, os seres e os homens, e de viver guiado por um ideal, uma utopia ou uma paixão. "O gênio é resgatado da abjeção da vida cotidiana para um mundo onírico de ilimitada liberdade de escolha. Aí ele vive não sôo livre dos grilhões da razão, mas da posse de poderes místicos que o habilitam a prescindir da experiência sensorial comum ${ }^{, 295}$.

O gênio como produto de forças irracionais, que não podem der definidas, introduz a convicção, comum ao movimento romântico, de que a irracionalidade é uma força positiva: "o caos constrói, compõe"296.

Importante para a formulação da idéia de "gênio" pelo movimento "Sturm und Drang" foram os conceitos estéticos de Shaftesbury (1671-1713) sobre a arte. Para ele, o importante na criação artística era resgatar uma identificação da subjetividade do artista com uma "verdade" do universo, através de processos não racionais, dando destaque para a ação da intuição no processo de elaboração da obra de arte, reveladora do belo ${ }^{297}$.

"A idéia de que a vida é uma obra de arte na qual o indivíduo trabalha guiado por um instinto infalivel ("senso moral”), tal como o artista é guiado por seu gênio, era uma concepção aristocrática adotada pela intelligentsia alemã (...),298

A posição do artista como "gênio criador" para Shaftesbury é bem semelhante com a proposta do gênio do "Sturm und Drang" no que diz respeito ao papel de revelador da "verdade divina" através da criação. A intuição do artista, em ambas proposições teóricas, traduzia uma concepção "panteísta" como centro da criação artística, que transmitiria os valores "divinos" por meio de sua subjetividade e originalidade.

\footnotetext{
${ }^{294}$ WELLEK, René. Op.cit. p. 162.

${ }^{295}$ HAUSER, Arnold. Op.cit. p. 616.

${ }^{296}$ BORNHEIM, Gerd. "Filosofia do Romantismo". In: GINSBURG, J. Op.cit. p.82.

297 "Ao proclamar que a beleza é verdade, Shaftesbury não entende a verdade no sentido de um conjunto de conhecimentos teóricos, de teses e de juízos redutíveis a regras lógicas fixas, a conceitos e princípios fundamentais. "Verdade", para ele, significa acima de tudo a harmonia interna do universo: harmonia que não se pode conhecer através de simples conceitos nem aprender intuitivamente colecionando e acumulando experiências particulares, mas com a qual é possível adequar diretamente nossas vidas compreendendo-a intuitivamente.” CASSIRER,Ernst. A Filosofia do Iluminismo. Campinas: Editora da Unicamp, 1994, p.414.

${ }^{298}$ HAUSER, Arnold. Op.cit. p.614.
} 
Nessa relação entre criação artística engendrada pelo "gênio" e uma visão "panteísta", o filósofo Ernst Cassirer diz de Shaftesbury: "Pois a oposição entre o homem e Deus é abolida desde que pensemos o homem não mais simplesmente em sua existência de "criatura" mas segundo a força criadora originária que o habita, não como ser criado mas como criador. Para que o homem revele-se verdadeiramente criado à imagem de Deus não basta que, demorando-se no círculo das coisas criadas, da realidade empírica, tente copiar-lhe a ordem e os contornos; é precise que ele crie esse modelo interior que é o ponto de partida de toda obra de arte, autêntica. (...). É o artista, em primeiro lugar, que dá incessantemente o mundo à luz em pequeno, que o gera, o produz sob forma objetiva, é a ele que o universo torna-se inteligível como obra daquelas mesmas forças que sente em si mesmo. Todo ser singular (ou gênio) nada mais é para ele do que um signo, um hieróglifo do divino (...) ${ }^{\text {,299. }}$.

Além do conceito de gênio, outro tema filosófico/literário capitaneado pelo movimento do "Sturm und Drang" e que será, posteriormente, aproveitado pelos autores românticos, foi o do "espírito do povo".

Pensando na singularidade e na formação histórica dos costumes dos povos, o filósofo "pré-romântico" Johann Gottfried Herder (1744-1803) fundamentou uma Filosofia da História que se contrapôs aos ditames ilustrados sobre a temática histórica, e ainda influenciou uma parte do pensamento de Hegel.

Para Herder, o "espírito do povo" estava interligado com os costumes nacionais e, principalmente, com as manifestações artísticas do povo, representadas pela poesia e a canção popular (Volkslied) ${ }^{300}$.Para o filósofo do "Sturm und Drang", o gênio, na fundamentação de Hamann, seria aquele capaz de captar a essência deste "espírito", representante do ponto nevrálgico da nação, e revelar à comunidade a sua linguagem oculta.

“O método de Herder é o natural, o método histórico, que vê cada obra como parte e parcela do seu meio e, em conseqüência, sente que cada uma delas está no seu lugar, desempenha a sua função temporal, e assim não precisa realmente de crítica”301.

Como já foi esboçado no presente capítulo, a teorização promovida por Herder e pelos outros pensadores do movimento "Tempestade e Ímpeto" se contrapunha às

\footnotetext{
${ }^{299}$ Idem, p. 417.

${ }^{300}$ Herder foi fundamental no reviver da poesia popular e folclórica como expressão cultural e na valorização do sentimento histórico dos povos. Para ele, a poesia, ao mesmo tempo era a "arte da imaginação" e a "música da alma" do poeta e, deveria estar também transpassada por uma vivência afetiva da comunidade, ou seja, do "espírito do povo", que se constrói (se forma ) historicamente. ${ }^{301}$ WELLEK, René. Op.cit. p.167.
} 
considerações iluministas sobre a finalidade do processo histórico, ou seja, no seu ponto teleológico. Enquanto os autores iluministas acreditavam no progresso material e humano dos povos no que diz respeito aos costumes por meio da educação de novos referenciais, com a crença numa Razão reguladora de atitudes cosmopolitas, nas concepções de Herder não há canais de contato entre os costumes dos povos, não há uma Razão que paire acima do nacional. A Razão está subordinada aos costumes e portanto, é relativa, ou seja, deve ser entendida por meio do contexto e da formação histórica de cada povo. O sentido de História, que só pode ser intuído a partir da reconstrução da vivência afetiva singular dos povos, muda conforme o "espírito do povo" na apreensão de suas particularidades ${ }^{302}$.

"Herder mantinha que qualquer atividade, situação, período histórico ou civilização estava dotado de um caráter exclusivamente próprio, de forma que a tentativa de reduzir estes fenômenos a combinações de elementos uniformes, $e$ descrevê-los ou analisá-los em termos de regras universais tendia, precisamente, a obliterar as diferenças cruciais que constituíam a qualidade específica da matéria em estudo, tanto no âmbito da natureza quanto no da história” ${ }^{\text {"303 }}$.

Para ter uma compreensão mais profunda do sentido de História, entendido como o processo histórico possuidor de uma finalidade, para Herder, não podemos negligenciar o alto teor cristão ${ }^{304}$ e a visão "panteísta" presentes no seu pensamento ${ }^{305}$. Cada coletividade é importante na captação de um particular "espírito", de uma essência íntima, mas para Herder, a tarefa última da História é revelar o caminho do

\footnotetext{
302 "Ele tinha realmente uma extraordinária capacidade para conceber uma grande variedade de sociedades possíveis e reais, no presente e no passado, e mostrava sempre uma cordial simpatia sem paralelo para com todas elas, inspirando-se na possibilidade de reconstruir formas de vida como tais, $e$ deliciando-se em expor seu caráter individual e a plenitude da experiência humana nelas incorporada; quanto mais estranho ou extraordinário era um indivíduo ou uma cultura, tanto mais satisfeito ele estava (...) completamente penetrado pelo novo espírito do empirismo e da inviolabilidade dos fatos". BERLIN, Isaiah. Vico e Herder. Brasília: Editora da Universidade de Brasília, 1982. p. 141.

${ }^{303}$ Idem, p. 133.

304 "O Cristianismo, explicou, é uma religião universal; ele abrange todos os homens e todos os povos; ele transcende todas as lealdades locais e temporárias, na adoração do que é eterno e universal”. Ibidem, p.143.

305 “A lei que rege o sistema do universo, que forma cada cristal, cada vermezinho e cada floco de neve, formou e rege também a minha espécie, fazendo da sua própria natureza a base da sua duração e continuidade, enquanto o homem existir. Todas as obras de Deus contêm em si a sua própria estabilidade e a sua maravilhosa conexão, porque todas elas, dentro dos seus limites determinados, dependem de várias forças antagônicas, mantidas em equilíbrio por um poder interno que as ordena. É guiado por este fio condutor que eu percorro o labirinto da história e vejo por toda a parte uma ordem harmônica e divina. Porque tudo quanto pode acontecer, acontece; tudo quanto pode agir, age; porém, só a razão e a justiça perduram, porque a insensatez e a loucura destroem a Terra e destroem-se a si próprias". Patrick Gardiner citando Herder. In: GARDINER, Patrick. Teorias da História. Lisboa: Fundação Calouste Gulbenkian; 1968, p. 58.
} 
humanismo ${ }^{306}$ para cada nação em sua individualidade ${ }^{307}$, de modo que todas possam traçar as "boas intenções”, mesmo que ininteligíveis, de Deus.

"No entanto, se existe um Deus na natureza, existe igualmente na história. Porque também o homem faz parte da criação, nos seus mais violentos excessos e paixões, obedece necessariamente a leis que não são menos belas e excelentes do que aquelas por que se regem todos os corpos celestiais e terrestres. (...).Se considerarmos a humanidade tal como a conhecemos e segundo as leis que lhe são intrínsecas, nada encontramos de mais sublime no homem do que o seu humanismo. Porque mesmo quando imaginamos os anjos ou os deuses, imaginamo-los como homens ideais, superiores ${ }^{, 308}$.

No âmbito de uma visão de mundo "panteísta", o discurso narrativo utilizado por Herder para descrever suas idéias sobre o processo histórico está cheio de uma perspectiva integradora entre os seres, numa imagem orgânica dos fenômenos históricos (acreditava num desenvolvimento natural ou inato em oposição a uma leitura interpretativa totalmente racional e calculada dos fatos) e correspondentes ao mundo natural $^{309}$.

Nessa correspondência entre o "reino dos homens" com os "fenômenos da natureza", no uso de imagens metafóricas, que podemos encontrar um aprofundamento do conceito de "espírito de povo", relacionando a gênese da individualidade de um povo particular com a vivência na natureza local.

"Tal como a água de uma nascente recebe do solo donde brota a sua composição, as suas qualidades actuantes e o seu sabor, assim o antigo caracter dos povos proveio de traços racionais, do clima, do tipo de vida e da educação, das ocupações primitivas e das acções peculiares a cada um desses povos. Os costumes dos antepassados enraizaram-se profundamente e tornaram-se o protótipo íntimo da raça”310.

A concepção histórica de Herder caracterizava-se primordialmente pela individualidade dos diferentes povos, sendo que o processo de constituição dessa

\footnotetext{
${ }^{306}$ Idéia de Humanismo entendido como substrato de comunicação e maior entendimento do homem com as manifestações do Todo.

307 “(...) toda a história dos povos nos aparece como uma escola de treino para a corrida que nos permitirá alcançar a bela coroa do humanismo e da dignidade humana. Inúmeras e celebradas nações de antanho atingiram objetivos menos elevados. Por que não atingiremos nós um mais puro e mais nobre?” Gardiner citando Herder. In: GARDINER, Patrick. Op.cit.p. 57.

${ }^{308}$ Idem.Op.cit. p. 54.

309 "Só tempos, lugares, caracteres nacionais -em resumo, a ação combinada de forças vivas na sua mais específica individualidade é que decidem de todos os acontecimento que ocorrem no reino dos homens, tal como decidem de todos os fenômenos da natureza” Ibidem, p.43.

${ }^{310}$ Idem, p.44.
} 
miríade de nações, como se fez de diversas maneiras, não cumpriria uma mesma lógica de funcionamento e o "destino", a perspectiva teleológica, seria, naturalmente, particular para cada comunidade nacional, mesmo que tendo a busca de uma concepção "humanista" como objetivo principal ${ }^{311}$.

"Se, portanto, a formação de um reino depende primordialmente do tempo e do lugar em que nasce, das partes que o compõem e das circunstâncias exteriores que o rodearam, vemos então que em grande parte o destino desse reino depende destes fatores, 312 .

Outro aspecto importante de se notar na obra de Herder, que também está integrado com sua visão "orgânica" e "panteísta" da História, é o papel da decadência irreversível das instituições dos povos, que automaticamente conduz a uma idéia de renovação e permanência do "espírito do povo", do essencial de cada instituição que mesmo na sua natureza finita carrega uma parcela de constância.

Sobre o caráter tênue da obra humana, Herder diz: “(...) de toda a região por onde temos andado, vemos como é transitória toda a obra humana, e até mesmo quão opressiva vem a tornar-se a melhor das instituições ao fim de algumas gerações. (...). A planta floresce e fenece; os vossos pais morreram e tornaram-se pó; o vosso templo cai por terra; o teu tabernáculo, as tuas tábuas da lei já não existem; a própria linguagem, eterno elo entre os homens, entra em desuso. E uma constituição feita pelos homens, uma instituição política ou religiosa, que só podem construir-se com base naquelas, essa devia, havia de durar eternamente?"313.

Essas considerações de Herder anunciavam uma concepção histórica "etapista", de gênese, desenvolvimento e queda de um momento da história de um povo para outro ${ }^{314}$, e identificada com a dinâmica do contexto, ou seja, o povo deveria ser analisado com base no contexto político, econômico, social e cultural de sua época e no conjunto de valores de seu "espírito".

"O mundo de Herder era orgânico, dinâmico e unitário; cada um dos seus ingredientes era, ao mesmo tempo, exclusivo e estava entrelaçado com todos os demais

\footnotetext{
311 "Cada "individualidade coletiva” é única e tem seus próprios objetivos e valores, que serão inevitavelmente substituídos por outros objetivos e valores éticos, sociais e estéticos. (...). Existe uma tensão entre o naturalismo de Herder e sua teleologia, sua cristandade e sua aceitação entusiástica dos achados das ciências naturais; (...)”. BERLIN, Isaiah. Op.cit. pp. 185 e 186.

${ }^{312}$ GARDINER, Patrick. Op,cit. p.45.

${ }^{313}$ Ibidem, p.46.

314 “As plantas da natureza fenecem, mas a planta murcha espalha por sua vez sementes, renovando-se assim a criação viva”. Ibidem, p. 50.
} 
através de uma infinita variedade de relações que, afinal, não podiam ser analisadas nem mesmo descritas completamente ${ }^{\text {315. }}$.

A idéia do estudo da dinâmica dos vários contextos históricos das nações, nas suas singularidades temporais, vista como depositório dos principais elementos caracterizadores do "espírito do povo", como tema não só do pensamento de Herder, mas de todo o "Sturm und Drang", pode ser analisado sob a luz de algumas idéias de Winckelmann.

“A grande importância de Johann Joachim Winckelmann para a cultura européia ocidental - não só alemã, pois sua obra principal, História da arte da Antiguidade [Geschichte der Kunst des Altertums], de 1764, é um dos principais monumentos de prosa clássica européia - consiste, conforme se sabe, na nova visão que forjou da Antiguidade clássica”316.

O pensamento de Winckelmann esteve marcado por uma nova perspectiva não só artística, valorizando a "simplicidade de beleza e idealidade nobre" da arte grega, mas também histórica.

Para Winckelmann o estudo da arte grega deveria estar identificado com a captação de um "espírito" específico aos gregos, pertencente a um determinado momento histórico que possibilitou a formação dum ideal de união entre corpo e espírito. Visão "contextualista" da interpretação histórica ${ }^{317}$ que iria influenciar os conceitos formulados pelo "Sturm und Drang".

A idéia de uma simples "cópia" da obra de arte grega pelos modernos, no julgamento de Winckelmann, seria impossível devido a princípios diferentes de concepções de vida e pela obra artística grega trazer em si, uma profundidade própria ao período, uma essência reveladora do "espírito" antigo ${ }^{318}$.

Surgiu no cenário intelectual alemão, a partir das considerações analisadas, uma percepção que os objetos, no caso de Winckelmann, a escultura grega, além de conter concepções artísticas e culturais de um determinado povo, poderiam revelar a índole mais profunda e essencial de um povo, seu "espírito".

\footnotetext{
${ }^{315}$ BERLIN, Isaiah. Op.cit. p.148.

${ }^{316}$ WERLE, Marco Aurélio. Op.cit. p.26.

317 "Mas se os antigos são diferentes de nós, eles o são em princípio, e a imitação não vai resolver o problema da arte moderna, que é cindida, radicalmente diferente da dos gregos”. Idem, p.33.

318 "A superfície não é imediatamente reveladora do caráter das obras de arte. Desse modo, a hipótese de uma espécie de tensão na obra de arte grega torna-se plausível, no sentido de que seria possível haver uma aparência reveladora de algo mais profundo. (...). E, sendo o critério de beleza grega algo que se apresenta no íntimo e não na superfície da obra de arte, a própria idéia de imitação, postulada por Winckelmann, torna-se complexa”. Ibidem, p.29.
} 
Para o "Sturm und Drang" além desse julgamento sobre a necessidade de identificar o "espírito", no estudo cultural de um povo, Winckelmann foi importante no julgamento negativo do comportamento dos modernos, desvinculados da natureza, dos ideais de simplicidade e coletividade, pontos de referência para uma crítica romântica.

De acordo com Winckelmann: “(...) os gregos eram livres, imitavam segundo a natureza; possuíam um espírito atlético e saudável, não corrompido como o dos modernos; buscavam uma beleza ideal a partir da natureza; não faziam mera cópia dela, mas a apreendiam como ideal. Esta beleza ideal era, junto a eles, sublime. A natureza era unida, espírito e corpo em perfeita harmonia, ao contrário dos modernos, que se caracterizavam pela cisão" 319 .

Outro personagem de destaque do movimento "Tempestade e Ímpeto" foi Johann Wolfgang von Goethe (1749-1832), que em sua juventude absorveu os principais eixos temáticos desse grupo, já expressos no presente capítulo, e produziu obras como: Gotz von Berlichingen ${ }^{320}$ (1773) e Os sofrimentos do jovem Werther (1774).

O romance epistolar, Os sofrimentos do jovem Werther, que tem como eixo central o tema do "gênio" (nesse caso Werther, o personagem principal, revela uma nova concepção de sensibilidade totalmente estranha aos outros homens), pode ser, brevemente analisado em duas partes.

$\mathrm{Na}$ primeira parte, o tema do amor está relacionado com a natureza (tema roussoniano de oposição ao artificialismo). Na segunda parte, o tema social é explorado, mostrando a incompatibilidade do indivíduo com a sociedade (outro tema presente nas idéias de Rousseau). A vida burocrática é mostrada como insuportável para o indivíduo "romântico" (impossibilidade de reconciliação com a sociedade) e Werther, o "anormal", é obrigado a refugiar-se no seu individualismo (subjetivismo) e na natureza sensível.

Depois de sua viagem à Itália, Goethe volta absorvido pelas idéias do classicismo "puro", diferente do classicismo francês, e começa a realizar um novo tipo de proposta artística. Uma espécie híbrida de arte, filha da experiência clássica italiana com os pressupostos do "Sturm und Drang".

Goethe criou um novo modelo de "clássico" que dialogou com as teses estéticas de Winckelmann e com o advento do movimento romântico. Em obras como Fausto

\footnotetext{
${ }^{319}$ Ibidem, p.32.

320 “O personagem central é o próprio Gotz, um cavaleiro da baixa Idade Média que luta ao lado dos camponeses pela liberdade destes. Todo drama está centrado nele, ele que é o herói virtuoso e fiel ao rei, mas opositor dos príncipes que exploram o povo" WERLE, Marco Aurélio. Op.cit. p. 23.
} 
(segunda parte) e Torquato Tasso concebeu uma estética "clássica- romântica" mais voltada a uma identificação com a humanidade e não somente com o "espírito do povo" e com a natureza.

O sentimento de "humanidade" ou "humanismo" esteve presente, de certo modo, nos escritos dos autores do "Sturm und Drang", mas é com Goethe e Schiller, que a imagem do "universal no particular" iria se intensificar e influenciar, principalmente, o romantismo do círculo de Jena e a filosofia de Hegel.

A Antiguidade era vista como o lugar da serenidade e simplicidade, do ideal de equilíbrio social, e como o tempo da "união" e da plenitude humana. Goethe e os "românticos", incluindo Holderlin, buscaram o verdadeiro sentido histórico e "espiritual" dos antigos em suas obras. Foi o culto "irracionalista" da Grécia estética.

Podemos dizer que o advento de uma consciência romântica e idealista na Alemanha, "se impregnou a fundo de pensamentos tão diversos como os da Ilustração, do "Sturm und Drang", dos românticos e da Antiguidade grega" 321 . Era o nascimento de uma sensibilidade que iria influenciar toda a modernidade.

\subsection{A Filosofia da História de Hegel:}

Para os objetivos dessa pesquisa, analisar o sentido de História para Alexandre Herculano com base nos seus romances históricos é totalmente necessário apresentar algumas idéias do filósofo alemão Georg Friedrich Wilhelm Hegel (1770 - 1831) no que se refere aos temas filosóficos/literários formulados pelo "Strum und Drang", tomando por exemplos, o conceito de "espírito do povo" e do gênio da nação, a idéia do papel das paixões nas realizações humanas e a visão de decadência e permanência do "espírito do povo" nos fenômenos históricos, como elementos de continuidade e desenvolvimento na sua Filosofia da História.

O pensamento filosófico de Hegel representa a vértice do diálogo entre as idéias românticas, iluministas e da experiência estética "clássica" alemã (fim do século XVIII/ primeira metade do século XIX).

Todas as obras de Hegel estão intrinsecamente ligadas e obedecem a uma rigorosa disciplina. Por exemplo, na sua Filosofia da História podemos encontrar ecos da Fenomenologia do Espírito. Se considerarmos, a grosso modo, ambas como a formação

${ }^{321}$ ROSENFELD, Anatol. Texto e Contexto - II. São Paulo: Editora Perspectiva, 1993, p. 260. 
do espírito ("Bildung”), o homem, com seu singular espírito e o espírito da história universal - fragmentado em cada povo.

O homem e a História caminham em direção à verdade, que o Todo, o Universal. O caminho, a formação ("Bildung”) do espírito apropria-se da experiência da exterioridade (no âmbito dos fenômenos) para elevar sua interioridade rumo à plenitude do Espírito que chega ao Absoluto. Este ideal do "universal no particular" de Hegel tem uma nítida influência do modelo "clássico-romântico" alemão e do mundo dos "Bildungsromane" ("Romances de formação"), que tem seu principal exemplo, talvez o único e o mais bem acabado, nos Anos de Aprendizagem de Wilhelm Meister (17951796) de Goethe ${ }^{322}$.

O espírito da história universal é formado pelos inúmeros povos do mundo, ou melhor, pelo ("Bildung”) destes espíritos determinados. Os "espíritos dos povos" (que estão interligados com os costumes nacionais) representam as particularizações, as fases do desenvolvimento do espírito universal histórico. Com esta idéia, Hegel introduz a Razão novamente na História (que seria o palco da harmonia imanente das paixões).

Retomando o exemplo dos Anos de Aprendizagem de Wilhelm Meister como um "Bildungsromane", num trecho, escreve Wilhelm: "Para dizer-te em uma palavra: instruir-me a mim mesmo, tal como sou, tem sido obscuramente meu desejo e minha intenção, desde a infância. Ainda conservo essa disposição, com a diferença de que agora vislumbro com mais clareza os meios que me permitirão realizá-los. Tenho visto mais mundo que tu crês, e dele me tenho servido melhor que tu imaginas. Atente, portanto, àquilo que digo, ainda que não vá ao encontro de tuas opiniões ${ }^{\text {323 }}$.

Este trecho da carta de Wilhelm a um amigo, Werner, expressa a condição individualista que o personagem se impôs, a sua formação, o desdobramento de suas potencialidades, e revela um novo conceito de experiência, integrando a vivência ideal e real $^{324}$. Ou pode ser interpretado, na perspectiva hegeliana, como uma conversa com o

\footnotetext{
322 “Com meios estéticos até então inéditos na literatura alemã, Goethe empreendeu a primeira grande tentativa de retratar e discutir a sociedade de seu tempo de maneira global, colocando no centro do romance a questão da formação do indivíduo, do desenvolvimento de suas potencialidades sob condições históricas concretas.” MAZZARI, Marcus Vinicius. “Apresentação” In: GOETHE, Johann Wolfgang Von. Os anos de aprendizagem de Wilhelm Meister. São Paulo: Editora 34, 2006, p.8. ${ }^{323}$ Idem. p. 284.

324 “As possibilidades e limites de tal realização (a busca pela Autonomia, Totalidade e Harmonia) são refletidos no romance - e, por extensão, nesse gênero literário - sendo que a meta (ou o "telos") da totalidade apresenta-se como contraste à imagem do protagonista ainda não desenvolvido ou “formado". É precisamente neste ponto que se constitui a tensão dialética, inerente ao romance de formação, entre o real e o ideal - ou então, como formulado por Hegel em sua Estética, entre a "prosa das relações" e a "poesia do coração". Enquanto elementos constitutivos do "Bildungsroman, estes
} 
Absoluto, ou seja, o sujeito toma consciência de sua individualidade espiritual, de sua liberdade espiritual e somente por meio desta "consciência-em-si", o indivíduo tem a possibilidade de se comunicar com o Todo, com o Universal ${ }^{325}$.

Este processo individual acontece também com os povos, ou seja, estes devem tomar "consciência-em-si" do seu espírito e chegar a "revelação da Razão Eterna conhecida no recôndito da razão finita" ${ }^{326}$. Em outras palavras, a auto-realização do sujeito e dos povos leva ao Todo.

As fases do processo de formação ("Bildung”) de Wilhelm Meister não desaparecem no seu transcurso, elas se conservam em seu espírito, por representarem o essencial no todo. O espírito universal da História é formado não só pela totalidade da "Bildung” dos povos, mas pela lembrança e o devir espiritual que estes povos trazem consigo. O "espírito do povo", em sua singularidade, já nasce com um sintoma de decadência e um devir. Os povos se modificam para se auto-realizarem.

“A história universal é o progresso na consciência da liberdade”327. O fim último do espírito universal da História é a Liberdade, a chegada e o vislumbrar do Todo. Cada povo tem uma finalidade, um papel, neste processo de rumo à Liberdade. Tudo obedece a um processo racional. "Ou seja, com o passar do tempo, os povos irão tomar consciência de seu espírito que é livre, igualmente os próprios indivíduos, com o caminho até a "consciência-em-si", descobrirão a liberdade”,328. A História obedece a um “otimismo histórico” mediado pela Razão.

A Razão age na História por meio do conflito, das paixões dos grandes indivíduos. Os homens são comandados pelas suas paixões, e um indivíduo realmente "apaixonado" não respeita os limites que as leis e a moralidade querem lhe impor, ele atravessa a “disciplina artificial e lenta da ordem e da moderação, do direito e da moralidade „329 em prol da meta de sua paixão.

pólos são, portanto, complementares, pois sem apoiar-se em sua respectiva realidade histórica o ideal de formação permaneceria inteiramente vazio e abstrato.” MAZZARI, Marcus Vinícius. Op.cit. p. 14.

${ }^{325}$ Dentro da perspectiva hegeliana: “(...) a ideia do Belo, para existir completamente, precisa sair do seu estado de immanencia e comunicar-se, exteriorisando-se na forma limitada e palpavel; por meio d'essa fórma, que é a sua antithese, isto é, até certo ponto negação da sua infinitividade, é que nos elevamos outra vez à concepção da ideia do Belo, e é por esta evolução fatal que o sêr precisa passar para atingir a plena existência na consciencia de si mesmo". BRAGA, Teófilo. História do Romantismo em

Portugal. Lisboa: Colecção Ulmeiro/Universidade, nº 6, (fac-símile da edição de 1880), Dezembro de 1984, p. 77.

${ }^{326}$ HARTMANN, Nicolai. A filosofia do idealismo alemão. Tradução de José Gonçalves Belo. Lisboa:

Fundação Calouste Gulbenkian, 1983, p.629.

${ }^{327}$ Idem, p.639.

${ }^{328}$ Ibidem,p. 639.

${ }^{329}$ HEGEL, J.W. A razão na história. Lisboa: Edições 70, 1995, p.73. 
O conceito de gênio abarca o indivíduo capaz de apreender o "espírito do povo" e por meio de sua paixão, leva-o, manipulado pelo instinto Universal inconsciente, a um novo estágio de sua "Bildung”, a uma nova transcendência que irá levá-lo para mais próximo do Absoluto, à Liberdade.

A paixão foge do domínio do indivíduo e cai sob o poder da Razão, que converte a finalidade pessoal "apaixonada" do indivíduo em finalidade Universal. Em outras palavras, o Universal entra na esfera concreta por meio do particular, do indivíduo apaixonado $^{330}$.

Os gênios, ou heróis, são responsáveis pelas "grandes tempestades", mudanças estruturais, na História porque, dominados pelo impulso de seu espírito apaixonado revelam o "espírito oculto", o espírito do devir para o povo, ou para o novo povo, que ainda não se configurou. Para a Filosofia da História de Hegel, os heróis acabam se tornando um instrumento do Absoluto, da Liberdade.

Estes gênios, os homens histórico-universais, "tiram de si mesmos o Universal que realizam; este porém, não foi por eles inventado, mas existe eternamente, realiza-se por meio deles e é com eles honrado"331.

A História é a realização da Razão Universal, e não da felicidade imediata dos homens e dos povos singulares. A paixão consome o homem, ou gênio, que está a serviço do Universal. "O indivíduo paga o grandioso que produz com a sua felicidade, o seu corpo e vida" 332 .

O movimento da História, para Hegel, é envolvido pelo espírito da Tragédia. O homem não é dono de seu destino, mas sim o Absoluto, que age sobre este por meio de suas paixões. O homem, como herói, segue sua paixão e acaba cumprindo os desígnios do Absoluto.

\footnotetext{
330 “ Portanto, direi paixão no sentido de determinação particular do caráter, de modo que essas determinações do querer não tenham somente conteúdo particular, mas constituam o estimulante e o atuante de ações gerais. Paixão é o lado subjetivo, formal, da energia, da vontade e da atividade, no qual o conteúdo ou o objetivo ainda permanecem indeterminados. (...). A História universal começa com o objetivo geral de que o conceito do espírito seja satisfeito em si, quer dizer, como natureza; ele é o instinto inconsciente interior mais profundo, e todo o trabalho da história universal é trazê-lo à consciência. Assim, na formação do ser natural, da vontade natural, existe o que foi chamado de lado subjetivo, ou seja, a necessidade, o instinto, a paixão, o interesse particular, tal como a opinião e a representação subjetiva. Essa imensa quantidade de vontade, interesse e atividade constitui os instrumentos e os meios do espírito universal para realizar o seu objetivo; para trazê-lo até a consciência e para concretizá-lo. (...) Porém, o que poderia ser questionado é se essa vitalidade dos indivíduos e dos povos, quando buscam os seus interesses e os satisfazem, é também meio e instrumento de algo mais sublime e abrangente - a respeito do que eles nada sabem, e que realizam sem consciência” HEGEL, Georg Wilhelm Friedrich. Filosofia da História. Tradução Maria Rodrigues e Hans Harden. Brasília: Editora da Universidade de Brasília, 2008, pp.28 e 29.

${ }^{331}$ HEGEL, J.W. A razão na história. Lisboa: Edições 70, 1995, p.87.

${ }^{332}$ HARTMANN, Nicolai. Op.cit.p. 647.
} 
“O interesse particular da paixão é, portanto, inseparável da participação do universal, pois é também da atividade do particular e de sua negação que resulta o universal. É o particular que se desgasta em conflitos, sendo em parte destruído. Não é a idéia geral que se expõe ao perigo na oposição e na luta. Ela se mantém intocável e ilesa na retaguarda. A isso se deve chamar astúcia da razão: deixar que as paixões atuem por si mesmas, manifestando-se na realidade, experimentando perdas e sofrendo danos, pois esse é o fenômeno no qual uma parte é nula e a outra afirmativa. $O$ particular geralmente é ínfimo perante o universal, os indivíduos são sacrificados e abandonados. A idéia recompensa o tributo da existência e da transitoriedade, não por ela própria, mas pelas paixões dos indivíduos"333

A idéia de que os gênios são dotados dum "espírito-trágico" é decorrência do resgate grego que seus contemporâneos estavam realizando. A Grécia "estética" que estava sendo retomada era diferente da visão grega iluminista. O resgate dos alemães girava em torno do "irracionalismo" grego, sinônimo de criação e imaginação.

A partir dessa visão o herói "histórico" hegeliano “(...) é o semideus, o ser híbrido em quem converge a dupla natureza de particular - da mortalidade - e de universal - do ser imortal. (...). Seguindo o destino dos heróis míticos, porém, o lado humano é castigado pelo divino, e os "grandes indivíduos” geralmente vivem tragédias similares às de Prometeu ou Sísifo, condenados a sentir na carne da sua particularidade um sofrimento sempre repetido pelo lado imortal ${ }^{\text {334. }}$.

A visão do gênio, que tem sua alma apontada ao Universal e que por este motivo "estraçalha" o indivíduo numa luta entre finito e infinito, pode ser relacionada com a idéia que Friedrich Schelling faz do herói trágico: “A adversidade, que abate e destrói sensivelmente a personagem trágica, é um elemento tão necessário à pessoa moralmente sublime, quanto o conflito de forças naturais e a supremacia da natureza sobre a mera capacidade de apreensão sensível o é para o fisicamente sublime. A virtude só se põe à prova na adversidade; a coragem, somente no perigo: na luta contra a adversidade, luta na qual não vence fisicamente, nem é derrotado moralmente, o corajoso é somente símbolo do infinito, daquilo que está além de todo sofrimento.

\footnotetext{
${ }^{333}$ HEGEL, Georg Wilhelm Friedrich. Filosofia da História. Tradução Maria Rodrigues e Hans Harden. Brasília: Editora da Universidade de Brasília, 2008, p. 35.

${ }^{334}$ GRESPAN, Jorge. "Hegel e o Historicismo". In: História Revista (Revista do Departamento de História e do Programa de Mestrado em História) - Universidade Federal de Goiás. Jan./Dez. 2002. p.72.
} 
Apenas no máximo de sofrimento pode se revelar o princípio em que não há nenhum sofrimento, assim como em toda parte tudo só se objetiva no seu oposto"335.

\subsection{A concepção de História de Alexandre Herculano: temas e idéias:}

Encontrar uma única e precisa linha de influência na concepção de História para Alexandre Herculano é tarefa bastante complexa e tortuosa, visto que o nosso autor passou por vários estágios formativos, com os oratorianos, o círculo literário da Marquesa de Alorna, a vida do exílio, o acesso a vários documentos históricos no seu trabalho de bibliotecário, a guerra civil de 1832, as disputas liberais, enfim, múltiplas experiências políticas e culturais aliadas a um insaciável "apetite" literário que forjaram um verdadeiro "amálgama" de influências teóricas nos princípios históricos e românticos de Herculano ${ }^{336}$.

Assim como alguns dos principais nomes europeus do século XIX, Herculano deu sentido e definição as suas idéias com base numa profunda preocupação histórica com as origens da nacionalidade e das instituições sociais e com o papel dos indivíduos no transcorrer do processo histórico ${ }^{337}$. Ou seja, observando e refletindo a realidade portuguesa da metade do oitocentos, assolada pelas indefinições trazidas pelo impacto da "dupla revolução", Herculano acabou formulando um coeso e impactante pensamento histórico.

Em relação ao seu pensamento histórico, podemos dizer que a proposta analítica mais comum feita pelos críticos, quando os mesmos se deparam com a tarefa de constatar as heranças do pensamento romântico que incidem nas idéias historiográficas de Alexandre Herculano, é fazer uma relação com os historiadores franceses, Guizot e

\footnotetext{
${ }^{335}$ SCHELLING, F.W.J. Filosofia da Arte. São Paulo: Edusp, 2001, p.126.

336 “(...) o seu pensamento avança por esta emaranhada estrutura, com terrenos delimitados para razão $e$ fé, cabendo à razão na caminhada para a Justiça, que é a Verdade Absoluta, o papel de ir detectando as leis do justo, (...)” COELHO, António Borges. Alexandre Herculano. Lisboa: Editorial Presença, 1965, p. 24.

337 “Apesar da immensa elaboração economica e scientifica, o século XIX distingue-se principalmente pelo genio histórico: a renovação intellectual partiu da abstração metaphysica para a critica, das hypotheses gratuitas para a sciencia das origens, do purismo rhetorico para a philologia, oppoz aos designios providenciaes o individualismo, deu as sciencias academicas, que serviam para alardear erudição, um intuito serio indagando nos factos mais accidentaes os esforços do homem na sua aspiração para a liberdade; só em um período assim positivo é que se podia achar a unidade de tamanha renovação; essa unidade é a Historia”. BRAGA, Teófilo. História do Romantismo em Portugal. Lisboa: Colecção Ulmeiro/Universidade, nº 6, (fac-símile da edição de 1880, Dezembro de 1984, p. 23. Herculano se encontra justamente na intersecção das idéias "científicas" do século XIX.
} 
Thierry $^{338}$. Não procurando, deste modo, estender o debate historiográfico com outros autores, que numa análise mais atenta das obras de Herculano, em destaque para os seus romances históricos, podem ser notados, mesmo que de uma maneira indireta ${ }^{339}$, no debate das idéias ${ }^{340}$.

Uma das heranças críticas do Romantismo que não pode ser negligenciada dentro do cabedal de princípios teóricos de Herculano diz respeito à vertente idealista/romântica da filosófica alemã ${ }^{341}$, iniciada por Herder e definida por Hegel. Tradição intelectual alemã identificada por autores como Fernando Catroga e António José Saraiva.

O historiador Fernando Catroga, para detectar influências do pensamento histórico alemão em Herculano, utiliza-se, basicamente, do trabalho de Albin Eduard Beau ${ }^{342}$, importante especialista na obra herculaniana, e de escritos do próprio autor, que apontam nomes como: $\operatorname{Herder}^{343}$, Schaefer ${ }^{344}$, Niebuhr, Savigny e Ranke ${ }^{345}$, entre outros.

\footnotetext{
338 "A metodologia de Herculano em nada difere da que se exercia nas obras e nos meios responsáveis da cultura do seu tempo. E Thierry e Guizot não eram ignorados em Portugal”. MACEDO, Jorge Borges de. Alexandre Herculano - Polémica e Mensagem. Portugal: Livraria Bertrand, Prêmio de Ensino Alexandre Herculano 1977/1978, 1980, p. 19.

${ }^{339}$ Não podemos deixar de destacar a circulação de autores alemães românticos e envolvidos, de alguma maneira, com as temáticas românticas na Europa, por meio de traduções e pelo diálogo de idéias. Um exemplo disso foi a publicação, em 1827, do livro de Edgard Quinet - Idéias sobre a Filosofia da História de Herder, que pode ter sido lido por Herculano ou absorvido por algum outro autor presente no seu campo de influências. Informações retiradas de Alberto Ferreira.Op.cit. p.44.

${ }^{340}$ Como no caso dos autores do "Sturm und Drang" (1767-1785). Periodização enquadrada por Karin Volobuef In Frestas e Arestas: A Prosa de Ficção do Romantismo na Alemanha e no Brasil. São Paulo: Fundação Editora da UNESP, 1999, p. 29.

341 "Os críticos allemães ao caracterisarem o Romantismo, apontavam a independencia absoluta dos cânones rhetoricos, o individualismo do sentimento, ou a inspiração como a verdade do modo de sentir individual, e as obras literárias baseadas sobre as tradições nacionaes de cada povo, e por isso escriptas não para as academias, mas para actuarem no conflicto das transformações sociaes. A palavra Romantismo tem este sentido complexo e profundo, porque accentua na civilisação occidental a relação achada pelo espírito moderno entre as suas línguas e as sua litteraturas" BRAGA, Teófilo. Op.cit. p. 68.

342 "Como já foi sublinhado por Albin Eduard Beau, o nosso historiador leu muitos historiadores alemães para recolher informações ou para refutar interpretações de factos respeitantes, directa ou indirectamente, ao nosso passado". CATROGA, Fernando. Op.cit. p. 62.

343 “(...) também se sabe que, nos finais da década de 1830, ele já tinha em mente elaborar "uma história de Portugal, segundo o esquema de Vico ou de Herder: uma história da civilização e não de batalhas" (In: "O Panorama", III, 1839, 6), embora tenha sido somente em 1842, com a saída, na Revista Universal Lisbonense, dos seus "Estudos de História Portuguesa" (mais tarde reunidas sob o título Cartas sobre a História de Portugal), que, pela primeira vez, explicitou idéias que já prenunciam a sua obra futura". Idem, p. 57.

344 "No entanto, foi a "Geschichte von Portugal" (vols. I e II: 1836; vols. III e IV: 1850-1854), de Schaefer, a obra estrangeira mais positivamente apreciada pela nossa historiografia oitocentista (Pinheiro Chagas, Teófilo Braga, Oliveira Martins). E o próprio Alexandre Herculano não lhe poupou elogios, considerando os seus juízos, sobretudo em relação ao período medieval peninsular, como "os mais notáveis que têm aparecido além dos Pirineus" (Herculano, Opúsculos, IV, 1985, 273)" Ibidem, p. 61.
} 
Entre as principais obras historiográficas alemãs que Catroga resgata de Albin Eduard Beau, como referências para Herculano, destacam-se as de cunho analíticas teóricas (importantes para interpretar instituições e caracterizar comportamentos individuais e sociais) e políticas. Entre elas se encontram:

"Geschichte von Danemark de Friedrich Ch. Dahlmann (1785-1860); (...) Geschichte von England (vol.I, 1834) de John Martin Lappenberg (1794-1865); (...) a decisive obra de Leopold von Ranke (1795-1886), Die romischen Papste im 16. Und 17. Jahrhunder (3 vols., 1834-1836) (...)” “(...) Deutsche Staats und Rechtsgeschichte (1808-1824) de Karl Friedrich Eichhorn (1781-1854); (...) Geschichte der Romischen Rechts in Mittelalter (1815-1831) de Friedrich Karl von Savigny (1779-1861); (...)”346.

Dentro dos escritos de Herculano que fazem referências diretas aos autores alemães podemos destacar o artigo sobre a Batalha de Ourique, inserido na polêmica com o clero português, onde nosso autor cita, diretamente, Ranke, Eichhorn, Savigny ${ }^{347}$ e Niebuhr ${ }^{348}$.

Tanto Ranke ${ }^{349}$, quanto Savigny e Niebuhr fizeram parte de uma linha metodológica historiográfica que ficou conhecida como Escola Histórica alemã, fomentadora de ideais analíticos presentes em vários autores do historicismo ${ }^{350}$

\footnotetext{
345 “(...) obras como as de Niebuhr, Guizot, Savigny, Ranke, que estarão na base da metodologia por que propugnará, tendo em vista a apreensão objectiva do passado”. Ibidem, p. 58. 346 Ibidem, p. 63.

347 “(...) sabem que passos gigantes tem dado a critica das fontes historicas. $O$ uso dessas fontes, a applicação dos preceitos a ellas, tem produzido historiadores como Ranke, Guizot, Eichhorn, Savigny, Amári, Maccaulay e tantos outros que a Europa inteira conhece e admira”. ”. HERCULANO,

Alexandre. "Solemnia Verba" (1850) - "A Batalha de Ourique”. In: HERCULANO, Alexandre.

Opúsculos - (Tomo III) - Controvérsias e Estudos Históricos (Tomo I). $7^{\text {a }}$ edição. Portugal: Livraria Bertrand, $1^{\text {a }}$ edição de 1881 , p. 70.

348 "Não foi no tempo da republica, foi sob o férreo domínio dos césares, que os poetas cantaram os mythos da gente romana, que os historiadores celebraram as suas glorias e deram a importância de verdade a centenares de lendas tradicionaes e fabulosas, que a sciencia moderna, as investigações do grande Niebuhr, reduziram já ao seu justovalor”. Idem, p. 116.

${ }^{349}$ Há uma polêmica sobre a natureza do enquadramento do "historicismo" ou "historismo" de Ranke, se esse pode ser denominado "historicismo romântico" ou não, discussão que não cabe no presente estudo, que só quer identificar uma vertente do pensamento alemão em Herculano. Mas, assim como Fernando Catroga dá indícios de uma influência romântica em Ranke, o historiador Hayden White também comunga com essa idéia. "A apreensão organicista do processo histórico proposta por Herder estava ainda presente na obra de Ranke como a metáfora pela qual o processo como um todo devia ser compreendido”. (...). "Os impulsos românticos por trás dos exercícios historiográficos de Ranke não podem, evidentemente, ser negados; ele mesmo deu testemunho da influência deles sobre seu pensamento durante sua juventude. Estão presentes em seu interesse pelo evento individual único e concreto, em sua concepção da explicação histórica como narração e em sua preocupação de penetrar no interior da consciência dos atores do drama histórico, para vê-los como eles se viam a si mesmos e reconstruir os mundos que eles enfrentavam no tempo e no lugar que lhes eram próprios”. WHITE, Hayden. MetaHistória: A Imaginação Histórica do Século XIX. São Paulo: Edusp, 1995, pp. 188 e 199.

${ }^{350}$ Para os objetivos desse estudo sobre Herculano, cabe dizer que "(...) para o "historicismo" $o$ essencial vem a ser o fato de que a História é - existe em si mesma, como processo real, imanente e intrinsecamente racional; mais ainda: a História evolui/desenvolve-se no tempo conforme a lógica
} 
romântico $^{351}$, como Guizot ${ }^{352}$ e Thierry, e que Herculano, absorveu a partir de vários ângulos, de diferentes tradições historiográficas nacionais.

“Em suma: nem as preocupações metodológicas foram monopólio da historiografia alemã - François Guizot escreveu páginas sobre a objectividade na reconstituição do passado que poderiam ter a assinatura de Ranke - nem a historiografia francesa teve o exclusivo das interpretações que convidavam a uma leitura mais dialéctica e social dos acontecimentos. Assim sendo, é restritivo filiar a propensão herculaniana para uma história mais social, em detrimento da história dos indivíduos, na exclusiva influência francesa. Fazê-lo é ignorar que tal posicionamento era, igualmente, compartilhado pelo historicismo romântico alemão, no seguimento da lição dos seus precursores setecentistas (Julius Moeser e Herder), autores que Alexandre Herculano bem conhecia" ${ }^{353}$.

Sobre a influência das idéias de $\operatorname{Herder}^{354}$ sobre o "historicismo" alemão ${ }^{355}$, Fernando Catroga escreve: “O romantismo historiográfico alemão dos princípios do

interna que the imprime sua própria direção ou "sentido" - o "progresso"”. FALCON, Francisco. "Historicismo: Antigas e Novas Questões". In: História Revista. Goiânia: Revista do Departamento de História e do Programa de Mestrado em História da Universidade Federal de Goiás, 7 (1/2), Jan./Dez., 2002, p.28.

${ }^{351}$ Em começos do século XIX, o historicismo entra assim em seu segundo momento, quando é possivvel distinguir pelo menos três tendências: o hegelianismo, a historiografia romântica e a "escola histórica alemã". O idealismo objetivo de Hegel (... ) realiza, através da fenomenologia do espírito e sua dialética, a identificação entre razão e história, entre o real e o racional. A História então, como singular coletivo, nada mais é do que a sequência, no tempo, da busca de si mesmo do espírito absoluto, que se manifesta concretamente em diferentes momentos (épocas/nações).

Ao contrário de Hegel, a concepção romântica, ao mesmo tempo que afirma a realidade da História, não a identifica como processo único e racional. Segundo os românticos, a História é, na verdade, o nome das formas e caminhos múltiplos e únicos através dos quais cada época e cada povo ou nação realizam sua própria "humanidade"”. Idem, p. 34.

352 "Em Guizot, terá confirmado (em Herculano) a importância da evolução das instituições políticas, a correlação destas com os grupos sociais e com a propriedade, as tensões inter-classistas, o papel dos municípios e da classe média, a distinção entre história interna e externa, com o seu interesse pela primeira, que estuda a índole da sociedade e as suas formas de organização, e o seu desinteresse pela segunda (que se debruça sobre a língua, os trajes, a cultura intelectual, as artes e a indústria).

Simultaneamente, Guizot tê-lo-á ajudado ainda a apreender o devir histórico através da luta entre os dois contrários, luta essa que, em vez de conduzir à síntese, apontaria para um necessário equilíbrio dos opostos (José Mattoso, 1980, XXVIII)”. CATROGA, Fernando. Op.cit. p.65.

${ }_{353}^{35}$ Idem. p.64.

354 "Na Alemanha, a reflexão histórica e a filosófica têm em Herder, por um lado, e em Schelling, Fichte e Hegel, por outro, algumas de suas manifestações exponenciais. Em Herder, a intuição da natureza histórica do homem e da sociedade conduz ao reconhecimento do caráter único de cada forma singular, destroçando assim o princípio de identidade. Daí toda a generalização abstrata não ser importante diante da História - toda situação humana possui seu próprio valor, toda fase histórica singular tem seu próprio direito à existência, sua necessidade imanente. Como partes de um todo, essas fases integram a unidade que só pode ser pensada como processo. A história deve concentrar-se naquilo que é peculiar, diferente, inefável, no sentimento de cada época.

Herder é o pai das noções de nacionalismo, historicismo e Volksgeist, e também um dos líderes da revolta romântica contra o classicismo, o racionalismo e a fé na onipotência do método científico." FALCON, Francisco. "Historicismo: Antigas e Novas Questões". Op.cit., p.33. 
século XIX acentuará todas estas características, procurando captar a "índole nacional" como um todo idiossincrático resultante da articulação das particularidades (arte, instituições, direito, canções populares, economia) em que se objetivava o “espírito do povo". Foi assim com Niebuhr, que, directamente motivado por valores nacionalistas, estudou a história de Roma numa perspectiva que privilegiou mais as instituições e a estrutura do Estado do que os indivíduos que o integravam; com Eichhorn, que, na fundamentação das raízes alemãs do direito, o apresentou como o produto de todos os factores que influem na vida de uma nação; ou com Savigny, que defendeu a necessidade de se compreender e sentir "a grandeza e individualidade de tempos passados, e a evolução orgânica dos povos e das constituições, de tudo, portanto, que deve tornar a História útil e fecunda"; ou ainda com Ranke, ao sublinhar que o historiador deve ter em mira apreender "as maneiras de pensar e viver dos homens, num determinado período" (Beau, 1964, 206)"356.

Podemos dizer que a metodologia historiográfica do "historicismo", alemão e francês, foi diretamente influenciada pelas idéias "pré-românticas" de Herder e do "Strum und Drang", principalmente do "espírito do povo", que vão definir a produção do movimento romântico, como um todo, e dar as bases temáticas para o romance histórico de Walter Scott, Victor Hugo e Alexandre Herculano.

Para António José Saraiva, a influência de um pensamento romântico de vertente mais germânica, incidiu em Herculano, além de seus conhecimentos diretos em autores como Klopstock e Schiller, a partir do "espiritualismo" de Victor Cousin.

As idéias de autores como Kant e Hegel, foram absorvidas por nosso autor com base em simplificações e arraigada numa perspectiva filosófica cristã própria do "espiritualismo" francês que Cousin fazia parte, que unia, por exemplo, princípios agostinianos e hegelianos.

“Reconhece-se aqui o ponto de vista hegeliano divulgado por Cousin: o Espírito realiza dentro da matéria a sua progressiva libertação; e a história não seria mais do

\footnotetext{
355 Também chamado de "historismo", a "Escola Histórica alemã" caracterizou-se pela análise objetiva dos documentos e por uma rigorosa metodologia histórica, mas ligada, ao "historicismo romântico". " $O$ ideal de cientificidade, a luta contra as "ficções românticas" e as "especulações dos filósofos" (leia-se aí Hegel) aproximam os historiadores da Escola Histórica do positivismo. Entretanto, quando se examinam mais atentamente seus pressupostos, torna-se quase evidente que o "historismo" da Escola Histórica constitui de fato uma forma, ao mesmo tempo específica e radical, de historicismo. (...). "Todavia, a Escola Histórica incorpora, em boa parte, a visão romântica do mundo e do homem, seu idealismo subjetivo, o individualismo metodológico, a visão holística de épocas e nações - cada uma destas com o direito de buscar sua perfeição única e incomparável, pois "todas são iguais aos olhos do Criador” Idem, pp. 38 e 39.

${ }^{356}$ CATROGA, Fernando. Op.cit. p. 64.
} 
que os episódios dessa libertação. Mas não é preciso recorrer a Hegel para encontrar a fonte deste pensamento: aplicado à história, o platonismo não podia deixar de ver nos acontecimentos formas sensíveis servindo de degraus para a plenitude do mundo inteligível. E o último estádio de história da civilização seria a cidade de Deus, o advento do reino divino. (...). Onde Hegel efectivamente inovou foi na definição do processo do desenvolvimento da Ideia, do trânsito de uma fase histórica para outra, da dialéctica pela qual o progresso se realiza. Nas Lições de História da Filosofia de Cousin podia Herculano ter encontrado, muito desfigurado aliás, a tese hegeliana segundo a qual as fases da Ideia se sucedem por contradição e síntese ${ }^{\text {357. }}$.

O conhecimento histórico de Herculano, interpretado sob a luz de uma miríade de autores e princípios românticos, configurou-se como extremamente eclético e fruto da experiência histórica européia do século $\mathrm{XIX}^{358}$. Quase tudo que era comum aos autores historicistas românticos pulsou no pensamento herculaniano, desde concepções espiritualistas/idealistas, representada por uma idéia de Providencialismo na História ${ }^{359}$, até concepções materialistas, de análises rigorosas dos documentos e da presença de uma idéia de luta de classes no processo histórico.

"Retrocedendo de Hegel ou de Vico para Bossuet ou Santo Agostinho, Herculano parece encontrar na Providência a ultima ratio histórica. É “a mão do Anjo do Senhor" quem escreve, com os caracteres das instituições, dos costumes, da ciência e da arte, a ideia de cada século (...) ${ }^{\text {360 }}$.

\footnotetext{
${ }^{357}$ SARAIVA, António. Op.cit. p. 89.

358 "Por tudo isto, mais importante do que detecção de "fontes" ou de "influências", directas ou indirectas, na formação do pensamento historiográfico de Alexandre Herculano, será a sua inserção numa tendência historiográfica que, com contributos alemães, franceses, ingleses, é comumente designada por "historicismo romântico". Este, a par do rigorismo metodológico defendido por alguns dos seus mais significativos representantes (Niebuhr, Ranke, Guizot, Herculano), pode ser definido como uma concepção que, entre outras características, pôs em voga as seguintes ideias: a história é um devir, sujeito a ritmos ascendentes ou descendentes (Vico), ou a processos de decadência (Herder); cada processo histórico tem uma individualidade absoluta decorrente da multiplicidade humana, embora se admita o uso do método comparativo para se inferir algumas generalidades; os fenómenos psicológicos, sociais, culturais são históricos, pois o objecto da história é a totalidade da existência, e cada época explica-se como uma unidade que deve levar em conta os seus antecedentes e as suas condicionantes (Rama, 1980, 118-119). Alexandre Herculano operou com algumas destas ideias, adaptando-as, porém, aos problemas específicos que investigou”. CATROGA, Fernando. Op.cit. p. 66.

359 “"Providência” é um conceito religioso; é apenas um nome que se dá à sabedoria e vontade de Deus, e supõe uma finalidade para o universo. Uma teoria providencialista da história é afinal uma interpretação religiosa dos acontecimentos. E com efeito é à luz do cristianismo que se explica a história universal, (...)”. SARAIVA, António. Op,cit. p.89.

${ }^{360}$ Idem, p.89.
} 
A idéia de Providencialismo histórico, perceptível no pensamento de Herculano, é captada não só por António José Saravia, mas também por Fernando Catroga e Maria Ivone Pereira de Miranda Fedeli ${ }^{361}$.

Ao contrário de Saraiva e Fedeli, Catroga identifica o Providencialismo de Herculano sob um enfoque mais crítico e relativo ${ }^{362}$, aprofundando ainda mais o

"ecletismo de idéias" do pensamento herculaniano, uma visão de mundo tradicionalista e cristã, herdeira de Santo Agostinho e Bossuet, conviveu com concepções "racionalistas" e de História.

"Por outro lado, tal como acontece com historiadores seus contemporâneos (como Benjamin Constant, François Guizot, Tocqueville, Ranke), a crença na providência não invalidava que se entendesse o homem, definido como sujeito-livre feito à imagem e semelhança de Deus, como responsável pelas suas acções, e que estas fossem passíveis de explicações exclusivamente profanas" ${ }^{363}$.

A idéia de Providencialismo, dentro do pensamento histórico de Herculano, deve ser estudada sob a luz da unidade de seus escritos, tanto a obra literária quanto a obra histórica não devem ser negligenciadas, ambas possuem uma reflexão sobre a idéia de devir histórico de cada povo, herdeira do "historicismo romântico"364, que passa por

\footnotetext{
361 "Há ainda um outro aspecto da ideologia de Herculano que estará profundamente ligado às obras que analisaremos (“A Voz do Profeta" e "A Harpa do Crente”). É o seu providencialismo. Para ele, embora o homem seja livre, o total dos atos humanos, o devir histórico é regido pela mão divina. A humanidade caminha inexoravelmente para estágios sucessivos de maior perfeição moral e material, guiada pela Providência. Os homens de bem são aqueles que colaboram, no seu agir individual, com os planos providenciais; os maus, aqueles que se lhes opõem.”. FEDELI, Maria Ivone Pereira de Miranda. Op.cit. p. 67.

"É ainda a ação providencial que vai implantando no mundo o liberalismo, em substituição às antigas instituições, pois " a Providência, que transformara o mundo antigo pelas invasões do setentrião, vai transformando as nações modernas pelas agitações intestinas. Lá empregou o ferro e as trevas; cá as revoluções e a discussão. A Lei providencial é a mesma; só a forma da aplicação é diversa"”. HERCULANO, Alexandre. “A Escola Politécnica e o Monumento”. In: Opúsculo III, p.133. In: Idem, p.67.

362 "É a partir do exposto que se deve situar a discussão acerca do peso da ideia de providência no seu pensamento. António José Saraiva sublinhou-a e viu nela uma componente tradicionalista dentro da modernidade geral do ideário herculaniano (SARAIVA, 1949, 100-116). Ora, deve salientar-se que a elucidação do problema aconselha a que se faça uma clara distinção entre os dois planos em que implicitamente Herculano se colocou: o da fé e o da razão científica. Enquanto crente (não praticante), ele terá perfilhado uma concepção deísta do mundo e, no consenso universal demonstrativo da dimensão naturalmente religiosa do homem, atribuía a superioridade (religiosa e ética) ao cristianismo; o que explica que, nos seus textos, e dentro de um tradição que remonta de Santo Agostinho e Paulo Orósio a Bossuet, surjam menções à providência como instância ordenadora da história. Mas, sintomaticamente, aquelas são muito mais freqüentes nas suas poesias, romances e nos seus escritos menores do que na História de Portugal”. CATROGA, Fernando. Op.cit. p.73.

${ }^{363}$ Idem, p.73.

364 “As criações individuais e sociais são históricas porque são únicas, irredutíveis e incomparáveis às de outras individualidades históricas. O universal se manifesta em cada indivíduo histórico particular, e
} 
princípios transcendentais, incompreensíveis para os homens, portanto, impossíveis de serem estudados ${ }^{365}$, e princípios “orgânicos”, lógicos dentro da imanência do processo históricos de cada povo ${ }^{366}$.

“Neste horizonte, as profissões de fé na providência podem perfeitamente coexistir com a crença na apreensão científica do passado" ${ }^{367}$.

No historicismo romântico de Herculano, uma leitura "orgânica" historicizante, identificadora da índole nacional, do "espírito do povo", a partir do estudo dos indivíduos e das instituições, apreendidos em elevado grau de $\operatorname{sintonia}^{368}$, convivia com uma atitude "científica" de análise documental ${ }^{369}$, herdeira de Guizot, Thierry e da Escola Histórica Alemã.

Para Alexandre Herculano o estudo do papel dos indivíduos dentro do desenrolar do processo histórico deveria se estruturar numa relação destes homens com o "espírito" da época em que viveram ${ }^{370}$. Não bastava um simples "biografia" dos "grandes homens", para se escrever História, esses indivíduos deveriam estar inseridos no funcionamento orgânico das instituições e nos valores morais de sua época ${ }^{371}$.

Em relação ao estudo isolado dos indivíduos históricos, Herculano escreveu: "Se foi um guerreiro, temos a descripção das suas batalhas; se legislador, a data e objecto das suas leis: mas o seu caracter, a medida intellectual e moral do seu espirito, os seus habitos e costumes, não os conhecemos. E porque? Porque esse homem é uma

a própria razão é, ela também, histórica. Organicista e providencialista, o romantismo compreende a totalidade em termos de união do eu com a natureza ou universo e com a comunidade - povo ou naçãoe sua alma coletiva. Enfim, em lugar da História Universal, a História Geral da Humanidade”.

FALCON, Francisco. "Historicismo: antigas e novas questões". In: Op.cit. p. 35.

365 Talvez venha daí a crítica de Herculano em relação à Filosofia da História.

366 “(...) o curso da história não resulta do somatório arbitrário das vontades individuais, mas está sujeito a uma causalidade objectiva que, mesmo quando não compreendida pelos seus actores, pode ser retrospectiva e analiticamente explicada” CATROGA, Fernando. Op.cit. p. 73.

${ }^{367}$ Idem, p. 74.

368 "A historia pode comparar-se a uma columna polygona de mármore. Quem quizer examiná-la deve andar ao redor della, contemplá-la em todas as suas faces. O que entre nós se tem feito, com honrosas excepções, é olhar para um dos lados, contar-lhe os veios de pedra, medir-lhe a altura por palmos, pollegadas e linhas. E até não sei dizer ao certo se estas indagações se teem applicado a uma face ou unicamente a uma aresta.". HERCULANO, Alexandre. "Carta IV" In: "Cartas sobre a História de Portugal”. In: Opúsculos - Tomo V (Controvérsias e Estudos Históricos - Tomo II). Portugal: Livraria Bertrand, Distribuidora para o Brasil - Editora Paulo de Azevedo, $5^{\text {a }}$ edição, p.100.

369 “Como ensinava a prática das ciências da natureza, também no conhecimento histórico se devia partir, de factos solidamente estabelecidos pela crítica documental, o que implicava, em termos metodológicos, ter de se colocar a "análise antes da síntese””. CATROGA, Fernando. Op.cit. p. 71. ${ }^{370}$ Idéia presente na sua obra Cartas sobre a História de Portugal (1842).

371 "Pouco bastará para nos persuadirmos de que a biographia das famílias ou dos indivíduos nunca pode caracterisar qualquer epocha; antes, pelo contrário, a historia dos costumes, das instituições, das idéas, é que ha de caracterisar os indivdiduos ainda quando quizermos estudar exclusivamente a vida destes, em vez de estudar a vida do grande individuo moral, chamado povo ou nação”. HERCULANO, Alexandre. "Carta IV”. Op.cit. p. 105. 
abstracção: está separado do seu seculo. As opiniões, os costumes, os usos, todos os modos, emfim, de existir da epocha em que viveu, são desconhecidos para nós; e todavia tudo isso, toda essa existencia complexa de muitos milhares de homens, a que se chama nação, devia ter uma influencia immensa, absoluta, naquella existencia individual do homem illustre, que o historiador acreditou poder fazer-nos conhecer com os simples extractos de quatro chronicas, cosidos com bom ou mau estylo ás respectivas certidões de baptismo, de casamento e de obito" ${ }^{372}$.

Desse modo, para uma visão mais panorâmica da História, Herculano enfocou seu estudo temático principal, como nas Cartas sobre a História de Portugal, publicadas em 1842, na análise da gênese das instituições portuguesas, destacando a origem das câmaras municipais na Idade Média portuguesa ${ }^{373}$.

Mesmo destacando o estudo dos costumes e das instituições nacionais como foco do estudo do historiador, Herculano refletiu e valorizou a atuação do indivíduo na História. O indivíduo, visto como ponto nevrálgico dos seus princípios políticos liberais, foi importante para sedimentar a lógica imanente do processo histórico ${ }^{374} \mathrm{e}$ também como "instrumento do absoluto"375, motivos teóricos do historicismo romântico da época ${ }^{376}$.

Em suas Cartas sobre a História de Portugal, mais especificamente na Carta V, Herculano defende uma postura analítica histórica sobre o "período medieval"

\footnotetext{
${ }^{372}$ Idem, p. 102.

373 “A historiografia portuguesa dos anos de 1834 a 1880, que o gênio literário de Herculano tão fortemente marcou, assenta nos quadros do movimento romântico. O clima espiritual que então se respirava na Europa e que recebia a seiva ideológica dos princípios da Revolução Francesa não podia deixar de se traduzir num tipo historiográfico que, cultivando a mais rigorosa erudição, procurava traçar a história genética das nações que haviam nascido à sombra da Idade Média. (...). O período medieval era tido como a época das grandes sementeiras que haviam conduzido à libertação do homem moderno”. SERRÃO, Joaquim Veríssimo. Herculano e a Consciência do Liberalismo Português. Lisboa: Livraria Bertrand, 1977, p. 81.

${ }^{374}$ Papel do indivíduo na História captado por Herculano na origem do "Reino de Portugal": "Província separada da monarquia de Leão pelos sucessos que em breve estudaremos e constituída como indivíduo político pelo esforço e tenacidade dos nossos primeiros príncipes e dos seus cavaleiros, o reino de Portugal formou-se pelos dois meios de revolução e da conquista. A independência cujos fundamentos obscuros lançou por morte de Afonso IV o conde do distrito portucalense, Henrique de Borgonha, independência consolidade pela sua viúva e estabelecida definitivamente por seu filho, foi completada pelas conquistas deste e dos seus quatro primeiros sucessores, até além do meado do século XIII, nos territórios mouriscos do Gharb ou ocidente”. HERCULANO, Alexandre. História de Portugal Introdução. Lisboa: Ulmeiro, 1980, $1^{\text {a }}$ edição de 1846, p. 58.

375 “Esta concepção de "grande homem" - que um historiador como Justus Moeser já havia antevisto -, entretanto popularizada pelohegelianismo, recebeu guarida quer nos eclécticos franceses influenciados por Hegel (Victor Cousin), quer nos idealistas românticos à Herder (Grimm, Goerres, Niebuhr, entre outros), (...)". "Ora, independentemente das influências directas ou indirectas que recebeu, é indiscutível que Herculano se integrou no grupo daqueles que entenderam o "grande homem" como o encarnador do gênio colectivo (...)”. CATROGA, Fernando. Op.cit. p. 75.

376 “Apesar dos propósitos de neutralidade do sujeito-historiador, a historiografia de Herculano, todavia, também não ficou imune aos condicionamentos da época”. Idem, p.76.
} 
português, que teria sua gênese no período da reconquista cristã da Península Ibérica até o advento de um modelo estatal centralizado, em detrimento da época do Renascimento, afirmando que a nação portuguesa durante a Idade Média, anterior à Revolução de Avis e à era dos Grandes Descobrimentos, teve, de fato, instituições que estavam de acordo com a sua índole e com a chegada do período histórico posterior, estas instituições entram em decadência.

"Em dous grandes cyclos me parece dividir-se naturalmente a história portuguesa, cada um dos quaes abrange umas poucas de phases sociaes, ou epochas: o primeiro é aquelle em que a nação se constitue; o segundo o da sua rápida decadência: o primeiro é o da idade-média; o segundo o do renascimento”377. (...).

"Como é a Idade Média a época em que Portugal vive de acordo com a sua índole, como é a Idade Média a época em que Portugal se fortalece e progride, é a Idade Média que Portugal deve ir procurar o remédio para os males que, pela história afora, o apoquentam" 378 .

No trecho acima, fica clara a importância dum conhecimento político construído retroativamente e é na Idade Média portuguesa, naquilo que Herculano considera como época medieval, que está há solução para os problemas que afligiam a nação. Assim como os acadêmicos ilustrados se voltaram para o período pombalino para estabelecer as continuidades e rupturas em relação à política estatal, como no caso de D.Rodrigo de Sousa Coutinho, o ilustrado romântico Alexandre Herculano ${ }^{379}$ volta-se para outro ponto do passado nacional com os mesmos objetivos dos ilustrados, tentar solucionar os impasses culturais e econômicos de Portugal.

“Mas, se a historia não é um passatempo vão; se, como toda a sciencia humana, deve ter uma causa final objectiva, ao contrario da arte que por si mesma é causa, e fim da sua existencia; se no estudo da historia pátria cada povo vai buscar a razão dos seus costumes, a sanctidade das suas instituições, os títulos dos seus direitos; se lá vai buscar o conhecimento dos progressos da civilização nacional, as experiências lentas e

\footnotetext{
${ }^{377}$ HERCULANO, Alexandre. "Carta V" In: "Cartas sobre a História de Portugal”. In: Opúsculos Tomo V (Controvérsias e Estudos Históricos - Tomo II). Portugal: Livraria Bertrand, Distribuidora para o Brasil - Editora Paulo de Azevedo, $5^{\text {a }}$ edição, p.129.

${ }^{378}$ HERCULANO, Alexandre. Cartas sobre a História de Portugal (1842). In: CARVALHO, Joaquim Barradas de. As idéias políticas e sociais de Alexandre Herculano. Lisboa: Seara Nova, 1971, p.72. 379 "A obra historiográfica da Academia das Ciências e dos seus membros mais destacados (Ribeiro dos Santos, Abade Correia da Serra, Sebastião de Aragão Morato, João Pedro Ribeiro, Visconde de Santarém, José Anastácio de Figueiredo e António Caetano do Amaral) constitui assim a prova da boa categoria da base documental e científica de que Herculano dispôs em Portugal”. MACEDO, Jorge Borges de.
} Alexandre Herculano - Polémica e Mensagem. Portugal: Livraria Bertrand, Prêmio de Ensino Alexandre Herculano 1977/1978, 1980, p. 17. 
custosas, que seus avós fizeram e com as quaes a sociedade se educou para chegar de frágil infância a virilidade robusta; se dessas experiências e dos exemplos domesticos, desejamos tirar ensino e sabedoria para o presente e futuro; (...) ${ }^{\text {380 }}$.

A História é vista por Herculano como local de aprendizado, da apreensão da "índole" Nacional, e o papel do historiador é resgatar as leis históricas que captam um "nexo lógico" entre as várias fases da História, através da caracterização dos períodos de "apogeu" e de "decadência" do processo histórico. Idéia próxima ao historicismo romântico da época e as idéias de Vico e de $\operatorname{Herder}^{381}$.

“(...) a ideia de Vico, expendida na sua Scienza Nuova, segundo a qual a história é percorrida por movimentos de ascensão (corso), que de uma fase ascendente caminharão inexoravelmente para a sua queda, de onde emergirá um novo curso (ricorso), vinha ao encontro de uma interpretação não rectilínea do percurso histórico, não escamoteando, assim, quer os momentos de apogeu quer os períodos de decadência, só superáveis mediante acções revivescentes. Simultaneamente, Herder ajudava a demostrar que a história, enquanto universalidade, resultava da correlação de totalidades orgânicas particulares, de indole espiritual e animadas por um evolucionismo sujeito a decadência. (...).

Ora, não será difícil demostrar que Herculano recorreu, se não à letra, pelo menos ao espírito destas concepções, ao assinalar a existência de dois grandes ciclos na história de Portugal: um de ascensão (da formação da nacionalidade até aos Descobrimentos) e outro de decadência (daquele último período até ao liberalismo)",382.

O próprio sentido de História para Herculano recaia numa imagem orgânica de “evolucionismo",383 histórico, intercalado por momentos de "ascensão" e "decadência",

\footnotetext{
${ }^{380}$ HERCULANO, Alexandre. "Carta V" In: "Cartas sobre a História de Portugal”. In: Opúsculos Tomo V (Controvérsias e Estudos Históricos - Tomo II). Portugal: Livraria Bertrand, Distribuidora para o Brasil - Editora Paulo de Azevedo, $5^{\text {a }}$ edição, p.131.

381 “(...), na última Carta, pretendeu Herculano traçar "o resumo da filosofia nacional”, tomando como base a origem da história portuguesa. Em que medida o grande Mestre se deixou embalar por uma reflexão filosófica sobre as formas de vida e de pensamento de um povo ao longo da sua história? Não há dúvida de que em 1842 o nosso autor enunciou uma espécie de teoria evolutiva da história, que não custa entroncar nas doutrinas de Vico, para defender que também as nações semelhantes, à semelhança dos homens, têm um ciclo vital que explica a sua variada permanência no tempo". SERRÃO, Joaquim Veríssimo. Op.cit. p. 91.

${ }^{382}$ CATROGA, Fernando. Op.cit. p. 79.

383 “As nações são em muitas cousas similhantes aos indivíduos; facil fôra instituir, não poeticamente, mas com todo o rigor philosophico, muitas analogias entre a sociedade e o homem physico. No individuo, cuja organização é viciosa ou incompleta, a idade viril passa rápida e quase sem intermissão se decae da mocidade para o pender da velhice: é esta uma verdade physiologica. Dae a qualquer sociedade uma organização incompleta, errada, ou sequer extemporânea; torcei-lhe as tendências do seu
} 
numa imagem de "espiral" dos acontecimentos ${ }^{384}$, identificado com uma base material, liberdade versus desigualdade, e com uma base espiritual, ação da Providência ${ }^{385}$.

Ainda em suas Cartas, Herculano faz uma clara escolha pelo espírito de “variedades” da Idade Média, presente nos “conselhos" das comunas e nos feudos (que segundo ele, não se estruturaram de maneira completa em Portugal) ${ }^{386}$, modalidades administrativas responsáveis pela descentralização das instituições, tornando a sociedade, desse modo, mais diferenciada, variada e equilibrada nas suas relações sociais e de poder, por exemplo, nas disputas entre rei e nobreza, nobreza e "terceiro estado" e rei e clero.

Fazendo um paralelo com as "Cartas sobre a História de Portugal", Herculano no “Apontamentos para a História dos Bens da Coroa e dos Foraes”, de 1843-1844, mostra a função dos "concelhos" como patrocinadores do equilíbrio dos poderes medievais: real, aristocrático, clerical e municipal.

“(...) finalmente, a união dos villões, que dispersos ou desunidos nada valeriam contra os nobres, mas que ligados por direitos, privilégios, e obrigações communs, constituíam entidades moraes fortes e activas, cujos interesses eram oppostos aos das classes aristocráticas (o alto-clero e a nobreza), e a que por isso a monarchia se

modo de existir primitivo; vergae os elementos sociaes, concordes com esse modo de existir, a uma formula política em parte diversa, e ficae certos de que esse vicio de constituição não tardará em produzir seu fructo de morte. A razão, bem como a experiência dos séculos, dá pleno testimunho desta verdade". HERCULANO, Alexandre. "Carta V" In: "Cartas sobre a História de Portugal”. In: Opúsculos - Tomo V (Controvérsias e Estudos Históricos - Tomo II). Portugal: Livraria Bertrand, Distribuidora para o Brasil - Editora Paulo de Azevedo, $5^{\text {a }}$ edição, p.132.

${ }^{384}$ Podemos citar como exemplos dessa imagem de "espiral" na concepção histórica de Herculano, trechos da Carta V: "Se houve uma grande mudança na existencia política de um povo, o caracter da geração que foi educada pelas antigas instituições e antigos costumes e que assistiu a essa transformação, poderá ser modificado por ella, mas conservará sempre os principaes lineamentos que lhe imprimiram as formulas sociaes que passaram."(...). "Nos acontecimentos humanos tudo vem sucessivamente; cada fato é um annel da cadeia eterna das causas e effeitos. O principio da unidade (identificado na monarquia) nunca deixou d'existir; (...)”. Idem, pp. 138 e 151.

385 "Convém lembrar que, antes das interpretações materialistas, as filosofias idealistas representavam a história como o palco da evolução espontânea do Espírito da humanidade. Posto Deus entre parêntesis, ou reivindicava a autonomia do agir humano em relação a Ele, o devir passou a ser visto como o gradual cumprimento de um plano da natureza que, no entanto, exigia a contradição e os antagonismos para se realizar. Por isso, mesmo nas filosofias mais optimistas e épicas, o sofrimento e o drama, talvez num eco inconsciente do pecado judaico-cristão, continuaram a ser expiações necessárias à redenção perfectível do homem". CATROGA, Fernando. Op.cit. p. 79.

${ }^{386}$ Próximo ao período em que Herculano defendia essas idéias, ele escreveu sobre o feudalismo em Portugal: “(...) o feudalismo foi um meio de progresso, um elemento de ordem, e por consequencia um bem, emquanto a civilização precisou delle - :o nosso intento é rectificar um grande erro histórico enraizado até em bons espíritos. Embora muitos dos costumes dos países da feudalidade se introduzissem entre nós, a essência da organização feudal nunca vingou na sociedade portuguesa: oppunha-se-lhe a índole della”. ”. HERCULANO. Alexandre. “Apontamentos para a História dos Bens da Coroa e dos Foraes” (1843-1844). In: In: Opúsculos - Tomo VI (Controvérsias e Estudos Históricos - Tomo III). Portugal: Livraria Bertrand, Distribuidora para o Brasil - Editora Paulo de Azevedo, 5a edição, p.228. 
alliava nas suas luctas com ellas. (...). A grande acção dos concelhos no progresso social da nação não foi prevista, ao menos até á sua derradeira conseqüência - a victoria da classe burgueza numa epocha remota que é a nossa: mas sentiu-se desde logo que elles eram um elemento de ordem e de força contra as violencias dos poderosos ${ }^{387}$.

Na Idade Média portuguesa, na leitura histórica de Herculano, o rei teria sua autonomia política comprometida pela força dos "concelhos", defensores de um poder municipal e, por conseguinte, o povo também não desfrutaria de plena soberania política devido ao poder do soberano. Um perfeito equilíbrio de poderes poderia ser sentido através da gestão dos conflitos sociais e políticos ${ }^{388}$.

No caso de Herculano, que julgava as instituições da sociedade medieval, em destaque para os "concelhos",389, como as grandes representantes do "espírito do povo" português, o passado medieval serviu para justificar a defesa duma postura de liberdade política dentro da sociedade portuguesa e da luta contra o despotismo, real e das massas.

Já o Renascimento, ou o conjunto de características políticas, econômicas e sociais que Herculano interpretou como pertencendo a tal período histórico, ligado ao momento do início duma centralização monárquica, anulou os valores estruturais da Idade Média em prol de uma unidade política e social absoluta ${ }^{390}$. Para Herculano: “o elemento monarchico foi gradualmente annulando os elementos aristocrático e democrático, ou,

\footnotetext{
${ }^{387}$ Idem, pp. 264 e 265.

388 "Havia, portanto, uma razão politica para o estabelecimento dos concelhos: o rei achava nelles seus naturaes alliados. Que esta razão fosse um calculo, uma idéa clara e precisa, um systema fixo dos primeiros reis, não o diremos; e até duvidamos muito disso. Mas era ao menos um instincto, instincto que as luctas com o alto-clero e as resistencias da fidalguia deviam todos os dias despertar.Assim a promulgação dos foraes, isto é, a instituição dos concelhos, torna-se cada vez mais freqüente, ao passo que os reis se habilitaram para terminar por uma composição vantajosa a guerra ecclesiastica, e para começar a grande empresa da sujeição da aristocracia secular". ”. HERCULANO. Alexandre. "Apontamentos para a História dos Bens da Coroa e dos Foraes" (1843-1844). In: In: Opúsculos - Tomo VI (Controvérsias e Estudos Históricos - Tomo III). Portugal: Livraria Bertrand, Distribuidora para o Brasil - Editora Paulo de Azevedo, $5^{\mathrm{a}}$ edição, p.212.

389 "Lá está a origem da energia sempre crescente do terceiro estado: lá foi lançada á terra a sementinha impalpável, que nascendo e vegetando no meio das procellas humanas, das transformações da nação, produziu no fim de seis seculos a arvore robusta da liberdade. Os pergaminhos, tostados pelo tempo, nos quaes forma escriptos numa linguagem sempre barbara, e ás vezes inintelligivel, os foros do homem de trabalho, são um dos mais sanctos monumentos da pátria; são os nossos brazões, de nós, os filhos do povo; são os nossos livros de linhagens". Idem, p.236.

${ }^{390}$ Visão também presente em outro escrito de Herculano. "Entre estas duas epochas é necessario suppor um período de decadencia profunda, moral e material, e esse período deve ser longo. Uma nação não decae de um dia para outro dia. A virtude e os recursos de Portugal deviam ter-se consumido lentamente.

Mas o que é esse período intermédio? É o estabelecimento da monarchia absoluta sobre as ruínas da monarchia liberal da edade-média. É a epocha dos descobrimentos e conquistas". HERCULANO. Alexandre. "Cogitações soltas de um homem obscuro" (1846). In: In: Opúsculos - Tomo VI (Controvérsias e Estudos Históricos - Tomo III). Portugal: Livraria Bertrand, Distribuidora para o Brasil - Editora Paulo de Azevedo, $5^{\text {a }}$ edição, p.35.
} 
para falar com mais propriedade, os elementos feudal e municipal, annulando-os não como existencias sociaes, mas como forças politicas. (...) o princípio monárquico se torna a única força política que a unidade absoluta se caracteriza rigorosamente e, sem aniquilar as classes sociais, as dobra, subjuga e priva da ação pública. Servas, elas se corrompem rapidamente; a gangrena eiva por fim o próprio trono; e em menos de um século, a nação portuguesa desaparece debaixo das ruínas da sua nacionalidade e independência”391.

Mas, dentro da concepção de História de Alexandre Herculano, a unidade absoluta $^{392}$ trazida pelo Renascimento e pela centralização monárquica possuía um "nexo lógico" no devir histórico ${ }^{393}$, onde há uma sucessão de elementos e princípios políticos e culturais necessários para os desígnios imanentes, que podem ser traduzidos em leis, e transcendentes, insondáveis para os indivíduos.

"É ahi que nós podemos comprehender o elemento monarchico; é ali que a sua acção apparece enérgica, civilizadora, progressiva; é ahi que elle disputa o predomínio aos outros elementos e que se faz popular, annulando-os. Obtido o triumpho, assemelha-se a todos os vencedores: degenera e corrompe-se nos ocios da victoria; sae das raias do organizador, e converte-se em oppressão. Nem d'outro modo podia acontecer: elle representava unicamente a ordem e a paz, e os elementos d'onde podia nascer a independência e a liberdade tinham sido completamente esmagados ou constrangidos ao silencio" ${ }^{394}$.

Nesse trecho, fica clara a imagem de "espiral" que Herculano construiu para entender o sentido de História, onde um elemento tem um período de ascensão num

391 HERCULANO, Alexandre. "Carta V" In: "Cartas sobre a História de Portugal”. In: Opúsculos Tomo V (Controvérsias e Estudos Históricos - Tomo II). Portugal: Livraria Bertrand, Distribuidora para o Brasil - Editora Paulo de Azevedo, $5^{\text {a }}$ edição, p.132.

392 "A designação de unidade e unidade absoluta com que classifica a época renascentista, parece-nos significar centralização do poder real, monarquia absoluta.” CARVALHO, Joaquim Barradas de. Op.cit. p. 74.

${ }^{393}$ Para frisar a importância da unidade absoluta implantada pelo Renascimento, Herculano destaca o "princípio da igualdade civil" dos súditos como fator de empecilho para os conflitos sociais medievais. "O principio da egualdade dos direitos e deveres fê-lo porém surgir, e converteu-o em facto geral, o predomínio da monarchia. Esta condição social, que nos parece hoje tão inconcussa, tão obvia, não poderia subsistir na epocha da completa desegualdade. Era necessária a existencia duma entidade política que, estando acima de toda a sociedade, tendesse constantemente a nivelar, pelo menos em relação a si, as outras entidades, e que finalmente o alcançasse. Era preciso que a opinião do poder divino dos reis chegasse a sanctificar-se com a decisiva victoria do elemento monarchico, para a egualdade civil se comprehender. As idéas actuaes a este respeito são apenas a conclusão inteira de certos postulados, dos quaes a monarchia tirara principalmente as conseqüências relativas a si". "Carta V" In: "Cartas sobre a História de Portugal". In: Opúsculos - Tomo V (Controvérsias e Estudos Históricos - Tomo II). Portugal: Livraria Bertrand, Distribuidora para o Brasil - Editora Paulo de Azevedo, $5^{\text {a }}$ edição, p.149

${ }^{394}$ Ibidem, p. 154. 
determinado momento propício do processo histórico, torna-se desgastado, opressivo e "decadente" até ser desbaratado por um outro elemento político, econômico e cultural que levará a sociedade para um novo momento, uma nova "fase", do devir histórico 395.

“Herculano diz-nos que determinada evolução não foi nem um bem nem um mal, foi uma necessidade ${ }^{396}$.

Até mesmo o setor social que Herculano denomina como "classe média", identificados com os profissionais liberais e pequenos proprietários, vetores do desenvolvimento duma sociedade balizada nos princípios de liberdade política e civil, com o acesso do poder absoluto, visualizando uma idéia de "luta de classes", se transformariam, com o tempo, em "classe opressiva".

Sobre a importância da "classe média" no pensamento de Herculano, António José Saraiva escreveu: "A classe média é a classe produtora ou trabalhadora; a classe privilegiada é a classe ociosa, que vive de um imposto lançado sobre o trabalho daquela. E é esta oposição de interesses que afinal gera as lutas do Terceiro Estado contra as oligarquias, que a partir de certo momento se identificam com a Coroa. Quer dizer que a concepção da história como luta de classes implica o predomínio das causas econômicas na evolução social”. (..... “(...) a classe média é a classe produtora por excelência, e deve chamar a si o domínio político do Estado”397.

A concepção de "luta de classes" 398 , identificada com a idéia de empate entre os princípios de liberdade e desigualdade, foi apontada pelo historiador Joaquim Barradas de Carvalho como um fator essencial na análise do pensamento histórico de Alexandre Herculano.

É principalmente no escrito herculaniano intitulado "Da Escola Politécnica e do Colégio dos Nobres”399, de 1841, que Joaquim Barradas de Carvalho defendeu que “(...)

\footnotetext{
395 "Dentro dessa lógica, o período decadentista surgia como uma espécie de experiência histórica transitória, mas fundamental, para se passar da "variedade sem unidade”, típica da vida medieval (em que as nações somente existiam "entre si"), para a "variedade unificada", que as nações modernas teriam de cimentar, a fim de conseguirem o equilíbrio superador das suas crises. Isto é, qual hegeliana astúcia da razão, (...)”. CATROGA, Fernando. Op.cit. p. 96.

${ }^{396}$ CARVALHO, Joaquim Barradas de. Op.cit. p. 160.

${ }^{397}$ SARAIVA, António José. Herculano e o Liberalismo em Portugal. Op.cit. pp. 173 e 176.

${ }^{398}$ Idéia herdeira do historicismo romântico de Guizot. "Guizot chega mesmo a ver, na luta de classes, a grande causa do progresso, o mais fecundo princípio de desenvolvimento da civilização européia”. CARVALHO, Joaquim Barradas de. Op.cit. p. 147.

399 “A primeira parte do texto nada de extraordinário nos mostra, pois Herculano considera a classe média, (...), como a classe ascendente da época, a classe progressiva. Considera-a também o traço de união entre o nobre e o humildade, a classe que dá estabilidade ao corpo social, aquela que evita a existência de uma barreira estanque entre o grande e o pequeno. O que de extraordinário existe no texto está na segunda parte, quando Herculano prevê que o domínio da classe média lhe escapará porque esse domínio se transformará de fonte de progresso em fonte de violências e opressões: "Como já houve
} 
com a concepção da luta de classes, na qual uma classe dominante, progressiva e revolucionária, no próprio quadro da luta de classes se transforma em regressiva e opressora" ${ }^{400}$.

Tanto os princípios de liberdade quanto de desigualdade ${ }^{401}$ entram naquilo que Herculano absorveu de "concepção materialista da história", e é através do conflito, do embate desses dois princípios antagônicos que se realiza a "luta de classes" na História, o processo histórico imanente, que Marx e Engels irão bem definir e estruturar adiante.

Como já foi apontado no presente estudo, a reflexão de Herculano sobre a História estava aliada a uma tentativa de esboçar soluções para os problemas políticos, sociais, econômicos e culturais vividos pelo país. A proposta de aliar trabalho e capital, descentralizar o poder central com o recrudescimento do poder local, representado pelos municípios, a criação de um banco municipal para facilitar o acesso do agricultor à propriedade e a instauração de uma ampla reforma educacional se justificavam com contato e estudo da História, num constante resgate e novas interpretações de momentos do passado nacional.

Para concluir podemos dizer que mesmo atento em esboçar um grandioso plano de reconstrução histórica nacional, não podemos deixar de mencionar a relação de Herculano com a idéia de "universal no particular" romântica herdeira do "Sturm und Drang" de Herder, onde o Absoluto realiza seu plano por meio do processo histórico de cada povo em particular, sentido de História presente tanto na História de Portugal P02 $^{4}$ quanto no Eurico de Herculano.

Para Fernando Catroga, o pensamento de Alexandre Herculano “(...) apesar do apelo às concretudes nacionais, (...) não escamoteou a dimensão universal da humanidade, posta em destaque pelo pensamento iluminista do século XVIII, como garante ontológico do tempo e do progresso indefinidos. Porém, também sublinhou a

tiranias aristocráticas e tiranias monárquicas, haverá tiranias burguesas, tiranias do balcão, da oficina, da granja, da fábrica...””. Idem, p. 152.

${ }^{400}$ Ibidem, p. 152.

401 “(...) o certo é que também Herculano supôs a existência de princípios contraditórios e omnipresentes no devir da humanidade e, particularmente, no da história de Portugal. A seu ver, as manifestações sociais e políticas de tal contradição derivavam da existência, na natureza humana, de dois princípios que a história, isto é, a acção dos homens, teria tornado antitéticos”. CATROGA, Fernando. Op.cit. p. 79.

402 "O nome de Alexandre Herculano ficou, sobretudo, ligado a esta grande obra, de que publicou quatro volumes: o primeiro, em 1846, com uma introdução histórica e englobando o período que vai do domínio árabe à morte de D.Afonso Henriques; o segundo no ano imediato, que trata dos governos de D. Sancho I, D.Afonso II e D.Sancho II, nos aspectos político e militar; o terceiro, em 1849, referente ao reinado do Bolonhês, com relevo para a definitiva conquista do Algarve e a organização administrativa; finalmente, o quarto volume, em 1853, que desenvolve os aspectos da formação orgânica do reino, mormente as instituições sociais e o povoamento”. SERRÃO, Joaquim Veríssimo. Op.cit. p. 97. 
sua outra face: o todo só se realiza nos povos, e estes não vivem em sincronia histórica entre si, porque a ideia progressiva e civilizadora não caminha ao mesmo ritmo; em cada século ou período, costuma escolher uma nação diferente que a representa. Com isto, dava guarida ao princípio herderiano, subjacente a todo o historicismo moderno, $e$ sintetizado no teorema da "não-simultaneidade de histórias diferentes mas cronologicamente contemporâneas", ,403.

\subsection{O sentido de História nos romances de Herculano:}

A proposta central desta última etapa do trabalho é captar alguns temas literários/filosóficos, analisados sob a perspectiva da Filosofia da História ${ }^{404}$ de Herder e de Hegel, que assim como na produção historiográfica de Herculano, particularmente nas Cartas sobre a História de Portugal, estão presentes nos romances históricos de Alexandre Herculano.

Para os objetivos da pesquisa, mostrar que Herculano, como autor ficcional, historiador e personagem de sua época, esteve vinculado a uma reflexão teórica sobre o processo e o sentido da História se constitui como necessário uma análise mais cuidadosa de seus romances históricos, particularmente do Eurico, vistos como instrumentos para a transmissão de sua visão sobre a História.

Desse modo, buscando um maior esclarecimento em relação ao suporte teórico da pesquisa, pretendo iniciar a análise ficcional com breves considerações sobre as possíveis relações entre História e Ficção, vista como fonte documental para o historiador, e sobre as razões históricas identificadas com a ascensão do gênero do romance dentro do movimento romântico.

\footnotetext{
${ }^{403}$ CATROGA, Fernando. Op.cit. p. 97.

${ }^{404} \mathrm{Na}$ correspondência que Herculano travou com Oliveira Martins na sua quinta de Val de Lobos, a "Filosofia da História" de Herder, Vico e Hegel é, indubitavelmente, desprezada pelo nosso autor. Mas, no período de 1834 a 1853, Herculano, no seu pensamento eclético, dialogou com concepções e temas dessa vertente filosófica, além da influência indireta que recebeu de autores do historicismo romântico alemão e francês. Assim como Fernando Catroga, Albin Eduard Beau, António José Saraiva, também Joaquim Veríssimo Serrão destaca essa influência nas idéias históricas de Herculano: "Reconheça-se que Herculano, ao lançar a Carta $5^{a}$ sobre a história de Portugal, se deixou embalar por uma certa visão filosofia, mas que ofez dentro de uma concepção real dos factos, fugindo ao mero devaneio ou à formulação de uma teoria exacta, para apenas se fixar nas razões que lhe permitiram compreender o devir da história nacional. Não era a abstração ou o simples enunciado de explicações desligadas da realidade histórica que então o conduziam. Cedeu à moda do tempo, impressionado pela leitura de Vico e Herder, mas com a nota positiva de apenas buscar as razões fundamentais da origem da Nação portuguesa. Essa linha orienta a última Carta, que contém as grandes teses que Herculano viria mais tarde a desenvolver”. SERRÃO, Joaquim Veríssimo. Op.cit. p. 92.
} 
Após essas considerações, exporei uma análise do Eurico, romance de Herculano que alcançou várias edições no período ${ }^{405}$, buscando identificar, dentro da lógica da obra, temas importantes no contexto cultural do Romantismo, como os conceitos de "espírito do povo" e de "herói”. Com a constatação da presença dos mencionados temas no romance histórico, uma análise interpretativa de um sentido de História para Herculano pode ser feita.

\subsubsection{Diálogos entre História e Literatura:}

O ponto de partida da presente discussão recai sobre a produção textual ficcional vista como suporte importante para a apreensão de pontos de vista e percepções de mundo de um autor, que podem auxiliar no desvendar acerca dos julgamentos de um período histórico.

Desse modo, “(...) a literatura, compreendida como uma manifestação cultural, permite o registro de um movimento que insere o homem em sua historicidade e apresenta chaves explicativas das idéias de uma determinada sociedade, abrindo ao historiador um novo campo para a pesquisa" ${ }^{406}$.

No caso de Alexandre Herculano, contemporâneo da ascensão do gênero do romance e da sociedade liberal e burguesa em Portugal, que possui uma ampla produção ficcional, nada mais lógico para o historiador se debruçar sobre este específico campo literário para desvendar, com mais acuidade, as visões de mundo do autor sobre a sociedade em que vivia e também seus julgamentos a respeito do conhecimento histórico.

Os estudos críticos preocupados em verificar, na obra historiográfica de Alexandre Herculano, em destaque para as obras História de Portugal (1846 -1853) e História do Estabelecimento da Inquisição em Portugal (1854-1859), a presença de um movimento histórico ligado a uma finalidade que se constitui historicamente e possuidora de um

\footnotetext{
${ }^{405}$ O historiador Fernando Catroga aponta sete edições do Eurico no período que Herculano esteve vivo. CATROGA, Fernando. Op.cit. p. 53.

${ }^{406}$ NEVES, Lúcia Maria Bastos Pereira das. “Apresentação”. In: NEVES, Lúcia Maria Bastos Pereira das; OLIVEIRA, Paulo Motta; DAVID, Sérgio Nazar e FERREIRA, Tânia Maria Tavares Bessone da Cruz. (orgs.). Literatura, história e política em Portugal (1820-1856). Rio de Janeiro: Eduerj, 2007, p.7.
} 
aspecto transcendental, negligenciaram a verificação do mesmo dado nas principais produções literárias de Herculano, que são seus romances históricos ${ }^{407}$.

O romance, visto não só como gênero literário, mas também como rico instrumento de pesquisa, pelo seu suporte ideológico e por possuir elementos reveladores de mudanças históricas nas sociedades européias modernas, remete-se, do mesmo modo, a Portugal oitocentista.

Do mesmo modo que no restante da Europa, onde a ascensão do romance esteve ligada ao advento duma consciência romântica ${ }^{408}$, baseada em visões de mundo contrastantes em relação às mudanças provocadas pelo advento da sociedade moderna industrializada, em Portugal o fenômeno histórico obedeceu ao mesmo princípio.

Pensando na relação da literatura com a dinâmica histórica do mundo podemos dizer que por meio do romance: “(...) assistimos ao processo lento e gradual de transformação das idéias e ilusões particulares de uma classe em ascensão em valores universais, isto é, em representações coletivas e universalmente válidas, uma vez que muitos de nossos autores assumiram o papel de seu porta-voz. O novo gênero teria, dessa forma, desempenhado função importante na criação de uma espécie de identidade de classe para os estratos médios ascendentes,(...). Trata-se de uma porta de entrada, um modo de ver como a nova classe foi construindo sua hegemonia cultural, conforme explicou Antonio Gramsci, pela obtenção de consenso para seu universo de valores, de normas morais, de regras de conduta, (...)" 409 .

O romance, como representante ideológico dos novos valores burgueses, como de liberdade política e autonomia dos sentimentos em relação às convenções sociais, também deve ser encarado a partir da crítica feita ao advento da modernidade capitalista, fruto de processos históricos realizados pela própria burguesia ${ }^{410}$.

\footnotetext{
${ }^{407}$ Podemos destacar como exemplo dessa tendência o crítico Joaquim Barradas de Carvalho, que em seu livro, As idéias políticas e sociais de Alexandre Herculano, faz uma análise do sentido do conhecimento histórico para Herculano enfatizando seus trabalhos de cunho mais historiográfico, sob a luz da influência dos historiadores românticos franceses, Guizot e Thierry, negligenciando sua produção literária, exemplarmente seus romances históricos, como fonte de pesquisa.

${ }^{408}$ Idéia que será analisada posteriormente com base nos trabalhos, por exemplo, de Georg Lukács e Sandra Guardini Vasconcelos. Autores que encaram a gênese do romance como "epopéia burguesa". ${ }^{409}$ VASCONCELOS, Sandra Guardini. A Formação do Romance Inglês: ensaios teóricos. São Paulo: Editora Hucitec/Fapesp, 2007, p.22.

${ }^{410}$ Visão defendida por Michael Lowy e Robert Sayre que por sinal compactuam com as idéias do sociólogo da cultura Lucien Goldmann: "Com efeito, em sua obra Sociologia do romance, Goldmann concebe o romance como colocando em cena o conflito entre a sociedade burguesa e certos valores humanos; o gênero romanesco exprimiria , assim, as aspirações de certos indivíduos "problemáticos”, motivados por valores qualitativos opostos ao reino do exclusivo "valor de troca": artistas, escritores, filósofos, teólogos, etc.” LOWY, Robert e SAYRE, Robert. Op.cit. p.30.
} 
O movimento romântico, inserido a partir das conseqüências da dupla Revolução (Industrial e Francesa), e conduzido pelo gênero romanesco, refletiu como nenhum momento cultural anterior, sobre sua realidade, como lugar de rupturas, continuidades e utopias, e antecedentes históricos. "O mundo como história é o objeto do romance, em que o caráter temporal e histórico da ação humana é problema sempre crucial e sempre presente para o romancista" ${ }^{411}$.

Assim como Georg Lúckacs ${ }^{412}$ e Lucien Goldmann, a pesquisadora Sandra Guardini Vasconcelos julga que o advento do romance esteve ligado às condições históricas do seu tempo, e se constituiu, como ponto crítico, na busca de um novo sentido de vida em um mundo corroído nas suas estruturas qualitativas e coberto de incertezas acerca de seus destinos.

Para Sandra Vasconcelos: "O desafio que se põe para os romancistas é o de figurar essa dinâmica social, de perceber a sociedade humana em seu movimento e de empreender o esforço de dar sentido e unidade a um mundo que começava a se desenhar como caótico e fragmentado, que apartava o privado e o público, o geral e o particular, o típico e o individual. A passagem de uma sociedade de status e privilégio para outra da aristocracia do dinheiro, a ruptura dos nexos entre homem $e$ comunidade, a condição de permanente mobilidade, a indeterminação da posição do sujeito no mundo, a busca de identidade constituíram uma nova realidade que se objetivou numa forma literária nova, que buscava, na apreensão e representação do real, captar esse movimento da vida contemporânea. Os embates do indivíduo com a ordem social passam então a ser tema privilegiado do romance, que encena o choque entre a "poesia do coração" e a "prosa do mundo" 413.

No caso de Portugal, a definição das origens de temas pertencentes a uma consciência romântica, como o subjetivismo e o sentimentalismo, são bastante controversas, sendo discutidas, de perspectivas diferentes, por diversos autores e especialistas.

\footnotetext{
${ }^{411}$ VASCONCELOS, Sandra Guardini. Op.cit. p.58.

412 "O romance é a epopéia de uma era para qual a totalidade extensiva da vida não é mais dada de modo evidente, para a qual a imanência do sentido à vida tornou-se problemática, mas que ainda assim tem por intenção a totalidade" (...) "O processo segundo o qual foi concebida a forma interna do romance é a peregrinação do indivíduo problemático rumo a si mesmo, o caminho desde o opaco cativeiro na realidade simplesmente existente, em si heterogênea e vazia de sentido para o indivíduo, rumo ao autoconhecimento” . LUKÁCS, Georg. A Teoria do Romance. São Paulo: Duas Cidades; Editora 34, 2000, pp.55 e 82.

${ }^{413}$ VASCONCELOS, Sandra Guardini. Op.cit. pp. 58 e 59.
} 
Numa perspectiva de continuidade de temas literários e de novos horizontes estéticos, a sensibilidade romântica pode ser encontrada nos escritos de Bocage e nas influências de gostos literários levados a Portugal pela Marquesa de Alorna ${ }^{414}$, para uma série de jovens escritores, entre eles, Alexandre Herculano. Mas, como Escola literária e artística, o Romantismo português parece ter surgido com força, somente na década de 30.

O Romantismo em Portugal, assim como em outros países da Europa, está vinculado às condições históricas de seu tempo, como ponto crítico e de análise à realidade que está inserido. Desse modo, apesar do termo "romântico" aparecer pela primeira vez, em 1825, no poema "Camões" de Almeida Garrett, foi só com o afastamento do absolutista D.Miguel do poder, em 1834, e com o início de uma monarquia constitucional de orientação liberal e inspirada pelas leis de Mouzinho da Silveira (que aboliram os direitos senhoriais) e as de Joaquim António de Aguiar (confiscando totalmente os bens da Igreja), ou seja, no estabelecimento de uma ordem burguesa, que o Romantismo conseguiu triunfar ${ }^{415}$.

"Só depois do regresso dos emigrados (exílio advindo das conseqüências da guerra civil de 1828-34) se verifica o fluxo contínuo de uma corrente literária inovadora. É preferível marcar o início do Romantismo em Portugal no ano de 1836, em que se publica $\underline{\text { A Voz do Profeta, de Herculano, segundo o modelo das Paroles d'un Croyant }}$ de Lamennais; em que aparecem as primeiras traduções de Walter Scott,(...) ${ }^{, 416}$.

Tradicionalmente, a crítica literária portuguesa trabalha os romances históricos do primeiro Romantismo português sob o campo de influência das obras de Walter Scott ${ }^{417}$

\footnotetext{
${ }^{414}$ Marquesa de Alorna, chamada por Herculano e pela crítica, de Madame de Stael portuguesa, por ser a iniciadora da influência de autores românticos em Portugal. "Os seus salões de S.Domingos de Benfica foram freqüentados durante toda a época das lutas civis e ainda depois da vitória liberal por literatos de gerações diferentes, desde os últimos árcades até os primeiros românticos, como Herculano, em quem despertou o gosto pelo romantismo alemão". SARAIVA, António José e LOPES, Oscar. História da Literatura Portuguesa. Portugal: Porto Editora, 1975, p.713.

${ }^{415}$ FERREIRA, Alberto. Perspectiva do Romantismo Português (1833-1865). Lisboa: Moraes Editores, 1979, p.32.

${ }^{416}$ SARAIVA, António José e LOPES, Oscar. Op.cit. p. 741.

417 “Os romances de Walter Scott revelaram ao público duas qualidades que constituíram a sua força extraordinária: a representação do passado com a verossimilhança do presente e o aparecimento na acção novelística - muitas vezes em primeiro plano - do povo, da gente simples e até da gente anormal e irregular, marginal como hoje se diz” CHAVES, Castelo Branco. O romance histórico em Portugal. Lisboa: Livraria Bertrand, Coleção Biblioteca Breve, 1979, p.60. Talvez o grande interesse em Walter Scott por parte de Herculano tenha se construído por causa da presença do homem social, moldado historicamente a partir das lutas entre os princípios de liberdade e de desigualdade traduzidos pelas instituições. "O prestígio da novelística foi resgatado, em primeiro lugar, por Scott, sobretudo pelo modo como manipulou o gênero de acordo com a visão historicista e científica da elite intelectual. Ele não só busca apresentar um quadro intrinsecamente verídico de uma situação histórica, mas também dota seus
} 
e de Victor Hugo e estabelece, apenas, uma tênue importância para as obras do PréRomantismo e Romantismo alemão. Sem dúvida, Walter Scott era o autor mais lido, mais traduzido em Portugal na década de 30 e oferecia um modelo de romance histórico que não podia ser desprezado ${ }^{418}$.

No bojo dessa idéia, não podemos deixar de destacar uma amplitude crítica da parte de alguns especialistas, como por exemplo, António José Saraiva, que nota a presença de Schiller e Klopstock, autores fundamentais para o desenvolvimento do movimento romântico alemão, em destaque para o círculo de Jena, na estética norteadora dos romances históricos de Herculano ${ }^{419}$, e Alberto Ferreira, que chega a fazer uma comparação direta da orientação estética do autor português com o modelo artístico preconizado pelo movimento cultural do“Tempestade e Ímpeto" 420 .

Podemos dizer, que de maneira geral, tanto a "escola romântica" portuguesa, quanto as demais "escolas românticas", estiveram, intrinsecamente relacionadas, com o Romantismo alemão e inglês, resgatando e interpretando seus temas e conceitos principais $^{421}$.

“Alguns dos principais temas do Romantismo alemão são divulgados em $\underline{\text { De }}$ l'Allemagne (1800) por Madame de Stael. Estes temas, assim como Schiller, Shakespeare (em moda na Inglaterra e na Alemanha), a rebeldia individualista de Byron, o romance histórico de Walter Scott vão influir no Romantismo francês, que é o mais tardio entre os das grandes literaturas européias ",422

romances de introduções, notas explicativas e apêndices, a fim de provar a fidedignidade científica de suas descrições". HAUSER, Arnold. Op.cit. p. 717.

${ }^{418}$ De acordo com os mapas de Franco Moretti os livros mais traduzidos na península Ibérica durante a primeira metade do século XIX foram os romances de Walter Scott, Alexandre Dumas, Eugene Sue e Victor Hugo, ou seja, autores da literatura francesa e inglesa. MORETTI, Franco. Atlas do romance europeu (1800-1900). São Paulo: Boitempo, 2003, p.188-189.

${ }^{419}$ SARAIVA, António José e LOPES, Oscar. Op.cit. p. 785.

${ }^{420}$ Numa diferenciação entre a produção literária de Garrett e Herculano, o crítico Alberto Ferreira, determina, baseado em duas linhas distintivas caracterizadoras da literatura portuguesa, elementos formadores desses dois autores: "Na história literária portuguesa a distinção entre estas duas linhas (inspiração noturna e inspiração apolínea) não parece ter-se verificado de modo abstrato. Todavia, há no iluminismo de Garrett claridades, optimismo e uma serena atividade que contrastam com a arte sombria de Herculano, influenciado pela onda de misticidade, pela exaltada consciência infleiz, pelo pendor irracionalista e nocturno de "strum und drang". FERREIRA, Alberto. Op.cit. p. 23.

${ }^{421}$ Sobre o Romantismo inglês é interessante citar: "O Romantismo inglês nasce sob o signo da luta antinapoleônica. Wordsworth e Coleridge exaltam à sua maneira um tradição nacional, em que entram como modelos literários Chaucer e Shakespeare e como inspiradora directa a poesia popular. Há evocações medievais em Coleridge, que é também influenciado pela filosofia romântica alemã, sobretudo por Schelling. Walter Scott, que inicia a sua carreira nesta época, sobredoira o feudalismo com a sua imaginação fecunda, que aliás recorta as figuras sobre o seu fundo histórico-social com um precisão desconhecida." SARAIVA, António José \& LOPES, Óscar. Op.cit. p.734.

${ }^{422}$ Idem, p.735. 
Na relação das idéias e temáticas da produção literária de Alexandre Herculano com o Romantismo alemão, não podemos esquecer que o nosso autor entrou em contato com esse cabedal romântico através de suas viagens, Inglaterra e França, do conhecimento de línguas, inglês, francês, italiano e alemão e por meio da influência da Marquesa de Alorna ${ }^{423}$. O próprio Herculano aponta a importância da Alemanha como exemplo cultural a ser seguido no jornal português intitulado Repositório Literário ${ }^{424} \mathrm{e}$ no Panorama.

Como mostra o nosso autor: "A Alemanha foi o foco da fermentação, e foi lá que os princípios revolucionários em litteratura começaram a tomar desde a sua origem uma consistência, e a alcançar uma totalidade de doutrinas methodicas e conseqüentes, não dada, ainda hoje, ao resto das nações" ${ }^{425}$.

"A influência da filosofia literária alemã tinha-se espalhado na Europa, e uma poesia livre e robusta fazia curvar diante do pensamento a forma, diante do ideal o material, diante do nacional o estranhos, diante do poeta a poética”,426

Com essas palavras não podemos negar o interesse da parte de Herculano pela produção intelectual na Alemanha $^{427}$, fato que o levou ao desejo de interpretar essas idéias sob o entendimento da cultura portuguesa, vista por ele, e pelo seu contemporâneo Almeida Garrett, como decadente e passível, devido às mudanças

\footnotetext{
423 “Entre os alemães, Alcipe (pseudônimo arcádico da Marquesa de Alorna) traduz Wieland, imita Burger e Goethe, iniciando nesses autores os seus discípulos. Obrigado pelos novos estudos, provavelmente é nesse tempo que Herculano, que já se dedicara ao italiano, aprende inglês e alemão, talvez guiado nas dificuldades pela benevolente Marquesa” FEDELI, Maria Ivone Pereira de Miranda. Op.cit. p. 50.

424 “A expressão teórica do Romantismo esboça-se em alguns dos artigos de Herculano publicados no Repositório Literário do Porto (1834-1835) onde se divulgam algumas ideias do Romantismo alemão, sobretudo de Frederico Schlegel, e continuados com artigos do mesmo Herculano sobre o teatro medieval e folclore no Panorama de 1837 a 1840.” Ibidem, p. 741.

${ }^{425}$ HERCULANO, Alexandre. "Qual é o estado da nossa literatura?" "Qual é o trilho que ella hoje tem a seguir” In: Repositório Literário (1834). Opúsculos (Tomo IX). Lisboa, Biblioteca Nacional de Lisboa (obra digitalizada): Typografia da Antiga Casa Bertrand, 1909, p.7.

${ }^{426}$ HERCULANO, Alexandre. "O Panorama" (22-VI - 1839). In: SARAIVA, António. Herculano e o Liberalismo em Portugal. Op.cit. Nota 29, p.147.

${ }^{427}$ Um dado apresentado pela pesquisadora Maria Beatriz Nizza da Silva revela o conhecimento das idéias de Herder, apontando a "generalização" dos fatos como o grande problema da filosofia de Herder. "O escrúpulo erudito de Herculano ajuda-nos a compreender o verdadeiro horror que sentia pelas generalizações apressadas, pelas sínteses construídas com dados mal estudados ou em número insuficiente". SILVA, Maria Beatriz Nizza. Alexandre Herculano - O Historiador. Rio de Janeiro: Livraria Agir Editôra, Coleção "Novos Clássicos", 1964, p. 7. A citação "negativa" a respeito de Herder, feita por Herculano, compreende um julgamento equivocado sobre o filósofo do "Sturm und Drang", já citado de maneira positiva num artigo do "O Panorama". Herder valorizava a análise dos aspectos reveladores da individualidade de cada povo e do estudo das origens históricas das instituições intrínsecas à "índole" da coletividade. Desse modo, o sentido histórico de Herculano, captado por meio dos seus romances históricos, possui mais pontos de ligação do que de distanciamentos com a idéia de História de Herder.
} 
políticas e econômicas causadas pelas revoluções liberais, de reestruturação e renovação.

A pesquisadora Maria Ivone Pereira de Miranda Fedeli diz que Herculano “menciona Goethe, Schlegel, Kant, Strauss e Herder,(...). Conhecia ainda todos os mais importantes historiadores alemães" ${ }^{428}$.

"Segundo Doellinger, (Herculano) se "com a literatura francesa mostrar-se familiar, mais ainda com as obras filosóficas, históricas e poéticas da Alemanha" ${ }^{429}$.

No diálogo com a produção cultural romântica européia do período, escreveu Herculano: "Desenterra a Alemanha do pó dos cartorios e bibliothecas seus velhos chronicons, seus poemas dos Nibelungos e Minnesingers; os escriptores encarnam na poesia, no drama e na novella actual as tradições populares, as antigas glorias germanicas e os costumes e opiniões que foram: (...) os povos do Norte saúdam o Edda e os Sagas da Irlanda, e interrogam com religioso respeito as pedras rúnicas, cobertas de musgos e sumidas no amago das selvas; todas as nações, emfim, querem alimentarse e viver da própria substancia. E nós?Reimprimimos os nossos chronistas? Publicamos os nossos numerosos inéditos? Revolvemos os archivos?Estudamos os monumentos, as leis, os usos, as crenças, os livros, herdados de avoengos?" ${ }^{430}$.

$\mathrm{Na}$ esteira dessa questão levantada, podemos dizer que Herculano determinava para si uma missão de perscrutador do passado nacional, com o intuito maior de revelar os pilares fundadores do "espírito do povo" português como fonte de inspiração para uma nova etapa da nação portuguesa. A transformação da literatura, para ele, era vista como substrato imprescindível para um completo despertar do povo português ${ }^{431}$, iniciado pela atitude revolucionária da luta contra o Absolutismo monárquico de D.Miguel.

Para Herculano a renovação do povo português passava, indubitavelmente, pelo conhecimento do passado, definindo desse modo, a vertente romântica de seu

\footnotetext{
${ }^{428}$ FEDELI, Maria Ivone Pereira de Miranda. Op.cit. p. 50.

${ }^{429}$ DOELLINGER. Gedachtnisse auf Alexandre Herculano. Munique, 1878. In: Idem, p. 50.

${ }^{430}$ HERCULANO, Alexandre. "Historiadores portugueses - Fernão Lopes". In: Opúsculos - Tomo V (Controvérsias e Estudos Históricos - Tomo II). Portugal: Livraria Bertrand - Distribuidora para o Brasil: Editora Paulo de Azevedo, $5^{\text {a }}$ edição, p.4.

431 “Infelizmente em nossa pátria a litteratura há já annos que adormeceu ao som dos gemidos da desgraça pública; mas agora ella deve despertar, e despertar ao meio de uma transcrição de idéias”. HERCULANO, Alexandre. "Poesia (Imitação - Bello - Unidade)". In: Repositório Literário (1835). Op.cit. p.24. Nessa citação de Herculano fica clara a sua intenção de renovar a literatura nacional, vista como elemento fundamental da cultura portuguesa, por meio da inspiração de outras literaturas, nacionalizando a renovação literária encontrada por outras, como no caso da literatura alemã.
} 
pensamento. Já que para o movimento romântico, de um modo geral, o passado era o local da busca do sentimento de comunidade e da origem do "espírito do povo".

Idéia que fica clara nas próprias palavras de Herculano, ao definir a importância do estudo do passado: "Ha neste falar das recordações de avós o que quer que é saudoso e sancto, porque a história pátria é como uma destas conversações d'ao pé do lar em que a família, quando se acha só, recorda as memórias do pae e da mãe que já não são, de antepassados e parentes que mal conheceu. Mais saboroso pasto d'espirito que esse não há talvez, porque em taes lembranças alarga-se o âmbito dos nossos affectos; com ellas povoamos a casa de mais entes para amarmos; explicamos pelos caracteres $e$ inclinações dos mortos, os caracteres e inclinações dos que vivem; os habita actuaes pelos habitos e costumes dos nossos velhos (...). As recordações da terra da pátria não são, porém, mais que as memórias de uma numerosa família" ${ }^{432}$.

Do mesmo modo que o trecho da Carta I, presente no escrito Cartas sobre a História de Portugal, enfatiza uma imagem do passado como local de diálogo afetivo e de alargamento dos horizontes de comunidade do povo português, os romances históricos de Herculano também buscam resgatar uma imagem histórica similar e que segue, do mesmo modo, uma visão de mundo romântica.

Para Herculano, a questão sobre a importância do romance histórico é amparada pelo tema da empatia com a História, ou seja, só conhecendo o "espírito" nacional por trás dos monumentos e das crônicas do passado, o leitor ou o cidadão português pode estabelecer um contato mais afetivo com a pátria, pensada como comunidade nacional.

Sobre a posição que o romance histórico deveria ocupar entre suas reflexões históricas, Herculano diz: "Quando o caracter dos indivíduos ou das nações é suficientemente conhecido, quando os monumentos $e$ as tradições, e as chronicas desenharam esse caracter com pincel firme, o novelleiro póde ser mais verídico do que o historiador; porque está mais habituado a recompor o coração do que é morto pelo coração do que vive, o gênio do povo passou pelo do povo que passa. Então de um dicto, ou de muitos dictos elle deduz um pensamento ou muitos pensamentos, não reduzidos á lembrança positiva, não traduzidos, até materialmente; de um facto ou de muitos factos deduz um affecto ou muitos affectos, que se não revelaram. Esta é a história íntima dos homens que já não são: esta é a novella do passado. Quem sabe

${ }^{432}$ HERCULANO, Alexandre. "Cartas sobre a História de Portugal - Carta I". In: Revista Universal (1842). Opúsculos (Tomo V) - Controvérsias e Estudos Históricos (Tomo II). Portugal: Livraria Bertrand, $5^{a}$ edição, Distribuidora para o Brasil - Editora Paulo de Azevedo, 1881 (1 $1^{\text {a }}$ edição portuguesa), pp. 34 e 35 . 
fazer isto chama-se Scott, Hugo, ou De Vigny, e vale mais, e conta mais verdades, que boa meia-dúzia de bons historiadores ${ }^{, 433}$.

No trecho citado acima, Herculano mostra a importância dos romances históricos de Scott e Hugo como escritos que ensinam mais que de "bons historiadores", porque estão mais acostumados a "recompor o coração do que é morto pelo coração do que vive, o gênio do povo que passou pelo do povo que passa", ou seja, apesar de citar os romances históricos mais lidos e conhecidos em Portugal como modelo condutor de traços e temas literários ligados ao "Sturm und Drang", como as idéias de "espírito de povo" e de "gênio".

Dentro da visão histórica de Herculano, o ponto de destaque do romance histórico é absorver o "espírito" da comunidade nacional, o que ela possui de mais íntimo e intrínseco, e revelar para os homens a verdade, não a "verdade histórica"434, mas aquela que conduziria a um conhecimento dos valores coletivos do corpo social e que romperia deste modo, o isolamento dos homens motivados pelo thelos da sociedade burguesa/capitalista. Com a essência do "espírito" da "numerosa família" revelada, a pátria portuguesa poderia ir para uma nova fase de integração e comunhão total.

No bojo dessas considerações podemos dizer que a narrativa, tanto a literária quanto a, estritamente, histórica, formavam, dentro das concepções românticas de Alexandre Herculano, um todo coeso e complementar. De um lado encontramos o historiador atento aos caminhos metodológicos e analíticos de seus documentos ${ }^{435}$ e do outro o romancistas preocupado em revelar o íntimo, a essência histórica do "espírito" do povo português, trabalhos formulados de diferentes formas, mas que comungam uma visão única sobre a História.

“As suas concepções de história social e história literária entrosam-se, como se comunicam a sua teoria histórica e a sua teoria estética, a sua escrita da história e a escrita da novela histórica, da poesia e do panfleto, e se implicam o seu ideal de arte e

\footnotetext{
${ }^{433}$ HERCUlANO, Alexandre. "A Velhice". In: Panorama, no 170, 01/08/1840, e Scenas de Um Ano de Minha Vida e Apontamentos de Viagens. Coordenação e prefácio de Vitorino Nemésio, Lisboa: Bertrand, 1934. Referência obtida do livro de Maria de Fátima Marinho. O Romance Histórico em Portugal. Porto: Editora Campo das Letras, 1999, p.16.

${ }^{434}$ Encarada, ironicamente nos romances históricos, através de supostos documentos achados em lugares indeterminados ou de difíceis acessos que serviriam de inspiração para a narrativa. Aspecto revelador de que Herculano, como historiador, sabia da existência de documentos e de relatos forjados e construídos com o intuito de dar um julgamento unilateral dos acontecimentos e dos fenômenos históricos.

${ }^{435}$ Não podemos deixar de lembrar que Alexandre Herculano participou do projeto Portugaliae Monumenta Historica (1856-1873) que tinha como objetivo recolher documentos valiosos acerca do passado português dispersos pelos cartórios conventuais do país.
} 
de nação, ética e estética, na busca e afirmação do princípio de uma nacionalidade artística ${ }^{436}$.

Os romances históricos de Herculano possuem a presença de personagens históricos reais agindo na trama com personagens fictícios, reconstituições detalhadas de costumes e instituições do passado português e assim como, seus trabalhos historiográficos, contam com toda a erudição de Herculano ${ }^{437}$. Desse modo, mesmo com o epíteto de "narrativas ficcionais", esses romances históricos, numa análise mais cuidadosa, podem figurar com igual importância dentro dos julgamentos acerca das reflexões e do sentido que o conhecimento histórico era captado pelo historiador Alexandre Herculano.

“Finalmente, passando por alto vários aspectos, Herculano deixou assinalado na novelística o seu interesse pelos estudos históricos e toda uma concepção da história. Os seus diversos romances abarcam o conjunto da Idade Média portuguesa, a cuja investigação se consagrou especialmente: no Eurico, no Alcaide de Santarém, o domínio árabe; na Dama Pé de Cabra, a época da Reconquista; no Bobo, a formação da nacionalidade; em Arras por Foro de Espanha, n'O Monge de Cister, na Abóbada, a crise que marca o advento da centralização régia" 438

De acordo com B. Capelo Pereira dentro do estudo da obra de Herculano há de se buscar uma unidade: “Compósita, dela ressalta uma profunda unidade, como tem vindo a ser sublinhado por estudiosos dos diferentes domínios: o poeta igualmente se revela na sua produção em verso como na sua obra em prosa; (...), o registro profético e visionário anima tanto a sua poesia como a novela histórica ou os seus textos de intervenção; os princípios da individualidade, da variedade e da liberdade são

\footnotetext{
${ }^{436}$ PEREIRA, B. Capelo. Verbete Herculano” In: BUESCU, Helena Carvalhão (Coord.). Dicionário do Romantismo Literário Português. Lisboa: Editorial Caminho, S.A, 1997, p. 224.

437 “(...) Herculano reclamava, com efeito, o conhecimento profundo das épocas a reconstituir, necessário à verosimilhança dos cenários, dos caracteres, das paixões, dos comportamentos e das situações imaginados; daí que chegue mesmo a perguntar-se onde maior "verdade" haveria, se na novela, se na história, pois não só reconhecia, como dissemos, ter qualquer historiador de suprir pela imaginação cadeias de factos e de razões ausentes dos documentos, mas admitir também que a dramatização dos tempos idos praticada pelo artista, com a sua forte capacidade de sentir e de visionar, podia ir mais longe do que a do historiador na reconstituição do passado, se as qualidades imaginativas e estéticas estivessem apoiadas por um "saber" seguro". CARDOSO, Margarida. "Alexandre Herculano”.In: Álvaro Manuel Machado, João Soares Carvalho, José Augusto França, Margarida Cardoso, Maria de Fátima Outeirinho, Maria Isabel Pires de Lima, Maria João Simões, Ofélia Paiva Monteiro (Colaboradores). História da Literatura Portuguesa (volume 4) - “O Romantismo". Portugal: Publicações Alfa, 2003, p.171.

${ }^{438}$ SARAIVA, António José \& LOPES, Óscar. Op.cit. p. 794.
} 
constitutivos da sua inteligibilidade da Idade Média, e portanto da sua teoria da história, como são constitutivos da sua teoria estética e sustentam a sua ficção; (...)"439.

A partir das opiniões de Herculano sobre os romances históricos, e seus julgamentos sobre Walter Scott e Victor Hugo ${ }^{440}$, e o lugar que esse tipo de narrativa ocupou na sua produção textual, podemos considerar esse gênero dentro do debate historiográfico do autor. Na visão do pesquisador José Américo Miranda: “Tanto maior será o historiador quanto maior for a sua capacidade de convencimento, o que se relaciona diretamente com a capacidade de recriação elou interpretação das épocas a cujo estudo se dedica" ${ }^{441}$.

De acordo com o pesquisador Paulo Motta de Oliveira, o próprio Alexandre Herculano põe em dúvida a distinção entre o papel do historiador e do romancista no que diz respeito ao método de interpretar e apresentar os fatos históricos, reportando-se a um trecho do romance histórico O Bobo (1843): "Mas porque não procuraram os vencidos (partidários de D.Teresa) amparar-se dentro dos fortes muros e torres do Castelo de Guimarães? É o que não nos diz a história. Pouco importa: di-lo-emos nós. A história não conheceu Dom Bibas, e Dom Bibas, muito em segredo o revelamos aqui aos leitores, nos oferece a chave deste mistério. O bobo, tornara impossível semelhante arbítrio, e porventura ajudava a descer do céu a benção que cubriu as armas de Afonso Henriques" ${ }^{442}$.

No bojo dessa questão podemos afirmar que também, de acordo com Castelo Branco Chaves ${ }^{443}$ e Fernando Catroga ${ }^{444}$, Herculano na época do "Panorama", periódico

\footnotetext{
${ }^{439}$ PEREIRA, B. Capelo. "Verbete Herculano" In: BUESCU, Helena Carvalhão (Coord.). Dicionário do Romantismo Literário Português. Lisboa: Editorial Caminho, S.A, 1997, p. 224.

440 "Nos seus romances e narrativas históricas, Herculano deu expressão a múltiplas tendências $e$ interesses que as Poesias, as obras polémicas e as obras históricas apenas parcialmente revelam. $O$ romance histórico, sobretudo como concebeu Vítor Hugo, era aliás um gênero de limites indefinidos, em que se misturavam a poesia, a erudição, o comentário e a efabulação" SARAIVA, António José \& LOPES, Óscar. Op.cit. p. 792.

${ }^{441}$ MIRANDA, José Américo. "Romance e História”. In: BOECHAT, Maria Cecília Bruzzi; OLIVEIRA, Paulo Motta; OLIVEIRA, Silvana Maria Pessoa de. Romance Histórico (Recorrências e

Transformações). Belo Horizonte: FALE/UFMG, Centro de Estudos Portugueses, 2000, p. 23.

${ }^{442}$ OLIVEIRA, Paulo Motta. “Alexandre Herculano: malhas da história, armadilhas da ficção”. In: Idem, p. 148. Sobre o trecho citado acima o pesquisador Paulo Motta Oliveira diz: "O tom irônico que o narrador aqui assume, parece-nos, apenas encobre o que todo o romance parece indicar: a recuperação do passado, feita de fragmentos, diferentemente do que considerava Aristóteles, não recupera o que aconteceu, mas apenas a face visível, e por vezes falsa, do que ocorreu. Apenas através da imaginação é que seria possível recuperar aquilo que, sem ela, estaria perdido nos desvãos do passado” Idem, p. 148. 443 "Herculano parece ter considerado a História e a novela histórica como dois elementos de actuação convergente. Mais: no entusiasmo pelo romance histórico, na admiração pela obra de Walter Scott“modelo e desesperação de todos os romancistas" - equiparava a História ao ficcionismo da história (...)”. CHAVES, Castelo Branco. Op.cit. p.30
} 
da publicação de suas narrativas e romances históricos, encarava o conhecimento histórico como algo explorado de maneira convergente tanto nas suas obras historiográficas quanto na sua produção literária

Para refletir sobre o ofício do historiador, que deve saber ler nas entrelinhas dos documentos e usar a "imaginação" para revelar apenas interpretações sobre um fato histórico $^{445}$, Herculano se utilizou da astúcia narrativa de um romance histórico, mostrando o potencial reflexivo de suas "narrativas ficcionais".

No romance O Monge de Cister, Herculano se vale de um "manuscrito" encontrado num determinado mosteiro, para contar a história de Vasco, e enumera a importância da "imaginação" na tentativa de interpretar e ilustrar o passado português.

“No meio, porém, de estudos tediosos e positivos, é impossível que o imaginar não descore, que o estilo não ganhe asperezas" ${ }^{446}$.

Mesmo influenciado pelo "historismo" da Escola Histórica alemã, por um rigor científico analítico $^{447}$, Herculano não conseguiu escapar de uma análise histórica típica do "historicismo romântico" "448, que levava em consideração o poder da imaginação na reconstrução narrativa histórica.

“Os "historiadores românticos" podem ser distribuídos ao longo de um eixo que corresponde ao seu comprometimento maior ou menor com a erudição documental. Infensos aos rigores empíricos positivistas, tais historiadores se servem, indiferentemente, de fontes primárias e secundárias e só raramente revelam preocupações críticas em relação a elas. Em geral, estão convencidos de que o elemento-chave é o próprio historiador. Cabe a ele, com sua intuição e imaginação, "recriar o passado" tal com este "realmente existitu": vivo e, sobretudo, humano. Daí

444 “(...) a ficcionação do passado era igualmente fruto da mesma sensibilidade que incitava aos estudos históricos, e ambos os gêneros moviam-se pela mesma preocupação educativa (moralizadora) e tinham subjacente uma similar aspiração ao conhecimento do já acontecido". CATROGA, Fernando. Op.cit. p. 51.

445 "Afinal, Portugal poderia ter surgido não por grandes feitos, mas graças a vingança de um reles bobo" OLIVEIRA, Paulo Motta. Op.cit. p. 149.

${ }^{446}$ HERCULANO, Alexandre. O Monge de Cister ou A Época de D.João I (Tomo I). In: HERCULANO, Alexandre. Obras Completas de Alexandre Herculano - O Monasticon (Tomo II). Introdução e Revisão de Vitorino Nemésio. Portugal: Livraria Bertrand, 1977, p. 345.

447 "A ficção histórica alimentava, assim, uma relação ambígua com a história-ciência, projecto contemporâneo de historiadores como Ranke, que, mediante a utilização de métodos de crítica documental, sonhava ser possível reconstruir o passado tal qual ele aconteceu”. CATROGA, Fernando. Op.cit. p. 50.

448 “(...) o critério de Herculano, mostra também que foi sensivel às limitaçães da indagação rigorosa na sua capacidade de reconstituição do passado. E de facto deixou frequentemente assinalada a necessidade em que o mais honesto historiador se encontra de praticar muitas vezes a dedução, num trabalho onde a imaginação se associa à informação escrupulosa na busca de uma verdade apenas presumível". CARDOSO, Margarida. Op.cit. p. 154. 
a importância que atribuem às motivações e intuições dos indivíduos históricos, aos sentimentos, anseios e manifestações individuais e coletivos (populares), ainda que mágicos ou fantásticos. A verdade histórica, nesse caso, não remete apenas a evidências empíricas, mas sim à persuasão retórica do historiador, à sua capacidade de fazer do leitor crer na verossimilhança dos acontecimentos por ele narrados. Historiar é uma arte, e a história é um gênero literário cujo cerne é a sensação de ilusão de realidade que o texto é capaz de criar e transmitir ao leitor ${ }^{449}$.

Confirmando as palavras de Francisco Falcon, o próprio Herculano, no Monge de Cister, ironiza a busca por uma verdade absoluta atribuída aos documentos, que no seu julgamento, devem ser minuciosamente analisados ao lado de um esforço "imaginativo" de interpretação histórica.

"Numa folha deixada em branco no fim do códice pergamináceo que nos conservou esta história havia vários parágrafos de letra mais moderna, contendo notícias de alguns dos personagens que figuravam nos acontecimentos até aqui relatados, personagens cujo ulterior destino o cronista antigo deixara de pôr em escritura. A letra parecia dos últimos anos do século XVI, quando os adeptos da escola de Brito e Lousada tomavam por seu desafogo o povoar de patranhas as solidões do passado. O moderno dos caracteres e a época embusteira em que essas adições haviam sido acrescentadas tornavam assaz duvidosa a sua autenticidade. Então o desejo de alimentar a curiosidade do leitor e o receio de faltar à exacção histórica, hesitávamos perplexos, como o asno de Buridam entre as duas taleigas de cevada. Enfim, resolvemo-nos a publicar em substância o conteúdo dos suspeitos parágrafos, com o protesto de que não respondemos pela sua veracidade ${ }^{450}$.

\subsubsection{Eurico, O Presbítero - A História e "o fogo das paixões":}

Os três romances históricos de Herculano foram concebidos e publicados, inicialmente, no Panorama e na Revista Universal Lisbonense, durante a década de 40, mas o primeiro a sair em volume foi o Eurico,O Presbitero, em 1844. Em seguida

\footnotetext{
${ }^{449}$ FALCON, Francisco. "Historicismo: Antigas e Novas Questões". In: Op.cit. p.36.

${ }^{450}$ HERCULANO, Alexandre. O Monge de Cister ou A Época de D.João I. Op.cit. p.328.
} 
temos o Monge de Cister, em 1848, que juntamente com o Eurico formam o Monasticon, e postumamente, O Bobo, em $1878^{451}$.

Assim como as histórias coletadas no livro Lendas e Narrativas, de 1851, Herculano desenvolveu um amplo panorama de reflexões estéticas e históricas com seus inúmeros personagens. Os principais temas românticos do "gênio", do sacrifício e da permanente presença do Absoluto no devir histórico foram reconfigurados por Herculano na sua proposta histórica romântica dentro de suas narrativas históricas.

“As principais personagens dos romances de Herculano são como que encarnações, dotadas de forças sobre-humanas, anjos ou demônios, consagrados a uma obra de maldição ou de santificação" ${ }^{452}$.

As obras de "maldição" ou de "santificação" promovidas pelos personagens de Herculano são frutos de intempestivas paixões, como vingança e amor ${ }^{453}$. Desse modo, assumindo uma postura apaixonada diante do mundo, estes personagens deixam de ser simples homens e passam a ser instrumentos do devir histórico.

Tanto o bobo D.Bibas, personagem central do romance $O$ Bobo, quanto Vasco, o monge de Cister, são acalentados por intensos desejos de vingança, e movidos por esse ideal apaixonado, acabam contribuindo para o desencadeamento de acontecimentos fora do foro íntimo e particular, repercutindo em conseqüências para o coletivo.

O personagem D.Bibas ${ }^{454}$ movido pelo desejo de vingança perante o Conde de Trava, Fernando Peres, amante de D.Teresa, infanta dos portugueses, ajuda Egas Moniz a fugir da prisão e abre as portas do Castelo de Guimarães para a conquista de D.Afonso Henriques, que se coroa como Rei de Portugal.

\footnotetext{
451 “Em 1843, Herculano começou a publicação, no Panorama, de O Bobo, obra a que parece ter dedicado particular interesse, a ponto de o retomar já no fim da vida, em Val de Lobos, para aperfeiçoamento e publicação em volume”. CHAVES, Castelo Branco. Op.cit. p. 32. ${ }^{452}$ SARAIVA, António José \& LOPES, Óscar. Op.cit. p. 793.

453 "O amor, a honra e o apego à pátria constituem os grandes mananciais da energia dos exaltados e desgraçados heróis do Escritor, sempre colocados em confronto com paixões ou interesses mesquinhoso preconceito social, a ambição de poder, a inveja, o orgulho; o idealismo positivo que os anima e os abre tantas vezes ao sentimento religioso se não à poesia (...), transtorna-se, quando contrariada e humilhada, em força destruidora que corrói o "eu" e muitas vezes persegue com cruel ânsia vingativa, dolorosamente sentida como diabólica, os responsáveis da inviabilização dos seus anelos”. CARDOSO, Margarida. Op.cit. p.173.

${ }^{454} \mathrm{O}$ bobo de D.Henrique simboliza os ideais de liberdade e equilíbrio social da Idade Média valorizados por Herculano. "Êste homem era o truão. O truão foi uma entidade misteriosa da Idade Média. Hoje a sua significação social é desprezível e impalpável; mas então era um espelho que refletia, cruelmente sincero, as feições hediondas da sociedade desordenada e incompleta. O bôbo, que habitava nos paços dos reis e dos barões, desempenhava um terrível ministério. Era ao mesmo tempo juiz e algoz; mas julgando, sem processo, no seu foro íntimo, e pregando, não o corpo, mas o espírito do criminoso no potro imaterial do vilipêndio. (...)Tal era o aspecto grandioso e poético daquela entidade social exclusivamente própria da Idade Média, padrão levantado à memória da liberdade e igualdade, (...)”. HERCULANO, Alexandre. O Bobo. São Paulo: W.M. Jackson INC, s/d, pp. 18 e 19.
} 
"A sorte das armas e a vingança de Dom Bibas tinham resolvido os futuros destinos de Portugal. Não foi esta a primeira vez, nem será a última, em que uma batalha ou um caturra influam na existência ou não existência, no modo de ser ou não ser destes corpos morais chamados nações, que apesar da sua individualidade, em rigor ideal e abstrata, não deixam de parecer corpos físicos, pela falta de vontade e inteligência" ${ }^{, 455}$.

Outro exemplo da ação das paixões como instrumento da História pode ser simbolizado nas atitudes guerreiras de Egas Moniz e Garcia Bermudes, homens que combateram no campo de S.Mamede, um ao lado de D. Afonso Henriques e o outro do Conde de Trava, guiados por um intenso amor por Dulce, nobre da corte de D.Teresa, e por um inominável ódio que ambos sentiam em relação ao rival amoroso.

“Nesta mesma ocasião dois guerreiros também rivais, mas rivais por um afeto mais violento ainda que a ambição (no caso, Herculano se reporta a Afonso Henriques e o Conde de Trava), haviam visto enfim satisfeito o seu ódio, encontrando-se. Ao pé deles nesse momento só combatiam peões. Egas, com a tenacidade de um demônio, com a prudência tranqüila de um rancor implacável, se esquivara a todos os grandes riscos da batalha, espiando o instante em que Garcia Bermudes, arrastado pela ebriedade do combate, se afastasse dos cavaleiros aragoneses que o seguiam. Êste instante chegou: o alferes-mor correra ao meio de uma ala de besteiros que recuava diante dos fundibulários da beetria de Gontingem. (...). Entre os dois proferiram-se algumas palavras. Eram baixas e rápidas: ninguém as ouviu; mas deviam ser atrozes. Quase a um tempo o montante de Garcia faiscou batendo no elmo do seu adversário, e a acha de armas de Egas esmigalhou o escudo do aragonês; depois por longo tempo não soou ali senão o restrugir do ferro no ferro, o ranger de dentes, e um rir sumido mas infernal. (...). Naquelas almas repassadas de furor, dos dois pensamentos de vida e de morte, não cabia senão um, e era ao segundo que ambos exclusivamente se abandonavam"456.

O que tornava Egas Moniz e Garcia Bermudes guerreiros formidáveis não eram a "ambição" e a "glória" buscadas por D. Afonso Henriques e pelo Conde da Trava. Segundo o julgamento de Herculano, os dois combatentes tornaram-se letais devido ao amor e o desejo de vingança. Sentimentos irrefreáveis e justificadores de um alto grau de sacrifício por parte do indivíduo, que com isso, na expressão de António José

\footnotetext{
${ }^{455} \mathrm{Idem}, \mathrm{p} .167$.

${ }^{456}$ Ibidem, pp. 171 e 172.
} 
Saraiva, ganham "força sobre-humana" e conduzem os rumos dos acontecimentos, se inseridos em momentos históricos oportunos.

Do mesmo modo, no romance histórico $O$ Monge de Cister, transcorrido no século XIV, Herculano, através do monge e ex-guerreiro Vasco, traça os efeitos incontroláveis da fúria das paixões, amor e vingança, nas ações humanas. E é por meio da busca por vingança perante a ofensa causada por Fernando Afonso diante de seu pai, D.Vasqueanes, e de sua irmã, D.Beatriz, e da infidelidade de sua amada D.Leonor, que Vasco, indiretamente, decifra toda a injustiça e maldade causadas pela decadente nobreza cortesã de D.João I de Avis, inaugurador da monarquia centralizadora.

O pai de Vasco, D. Vasqueanes, representa a antiga nobreza medieval, guerreira, religiosa e afeita a um valoroso código de honra, que não encontra lugar num Portugal de monarquia centralizadora e contemporâneo de uma nobreza cortesã, dotada de códigos de conduta artificiais e afastada do convívio com a terra. E é em nome desse conjunto de ideais perdidos que Vasco se vinga, cumprindo a risca o desejo final que seu pai o deixou ${ }^{457}$.

“Meu Vasco, meu Vasco! Onde estás, cavaleiro, filho e neto de cavaleiros, onde estás tu?! Olha o que o meu montante enferrujado já não pode sair da bainha; olha que as pernas trôpegas de um velho já não podem apertar as ilhargas de um ginete! Vem! Olha que cuspiram no brasão de teus avós. Lava esta nódoa com sangue!"458.

A conduta de Vasco, sombria e ambígua em relação a seus sentimentos ${ }^{459}$, é típica de um personagem romântico, onde mesmo atormentado por remorsos, como o causado pelo assassinato de Lopo Mendes, tem a alma apontada, incondicionalmente, para sua missão, a vingança da honra, alimentada pelas artimanhas e conselhos de D.João de Ornelas, abade de Alcobaça.

\footnotetext{
${ }^{457}$ Herculano, comentando o empenho de Fr. Lourenço em acalmar as paixões destrutivas de Vasco, corrobora com uma, inconfundível, visão de mundo romântica: "Também nós não protrairemos por mais tempo esta cena de luta moral, em que o virtuoso velho trabalhava por salvar um desgraçado, que nascera bom e honesto, e que a sociedade fizera culpado. Mentirosa, corrupta e má, a vida social, cheia de erros, preocupações e vícios, danada nas instituições e nas leis, nas crenças e nos costumes, educa as gerações e os indivíduos, legando-lhes largo cabedal de perdição; (...)".HERCULANO, Alexandre. O Monge de Cister ou A Época de D.João I (Tomo I). In: HERCULANO, Alexandre. Obras Completas de Alexandre Herculano - O Monasticon (Tomo II). Introdução e Revisão de Vitorino Nemésio. Portugal: Livraria Bertrand, 1977, p. 64.

${ }_{458}^{4}$, Idem, p. 37.

459 "Vago e monstruoso, como aquele longo vulto de muitos vultos, como aquele vozear de muitas vozes, era o que se passava em mim: se aflição ou prazer, remorsos do crime ou contentamentos da vingança, sede de mais sangue ou desejo de perdão, ódio imenso ou amor desperto de novo com dobrada ânsia é o que não saberei dizer-vos. Porventura, era isso tudo, que a um tempo me assaltava e despedaçava o coração". Ibidem, p.59.
} 
Talvez o único momento, em todo o romance, de manifestação da originária pureza do espírito de Vasco, perdida pela ação da maldade e decadência da época, como Herculano deixou frisado no seu discurso, seja a cena de perdão e compaixão a sua irmã Beatriz, enferma pela tristeza do amor rejeitado ${ }^{460}$. Sendo esse breve momento esquecido pela obrigação da vingança.

$\mathrm{Na}$ visão de Herculano, Vasco representa a dor que não pode ser curada, porque além de representar a honra ferida de seus familiares, sua enfermidade é fruto dos valores morais e sociais da cidade de Lisboa do século XIV, que apesar do bom funcionamento dos concelhos municipais, já começam a fraquejar.

Sobre Lisboa diz Herculano: "Era então como a filha donzela e inocentinha do honrado e guerreiro Portugal, bom soldado da Idade Média, a quem riquezas de conquistas e embriaguez de glórias fizeram dissoluto, e a dissolução fez antes da velhice caduco.(...). Cidade, donzela e pura do século XIV, porque rasgaste o teu véu de inocência? Porque quebraste o cinto que te dera o rei que tanto te amou? Por que te aproximaste à foz do Tejo, convocaste os estrangeiros e converteste a tua morada em lupanar?Foi porque teu pai perdeu na idade grave as virtudes da idade viril"461.

Vasco cumpre a sua missão vingativa, faz com que o Rei D.João I condene D. Fernando Afonso, mas, o monge de Cister morre exausto e infeliz, na figura de um romeiro, diante dos olhos de Fr. Lourenço.

Alguns personagens de Herculano brevemente analisados até o momento, como Egas Moniz e Garcia Bermudes, são os representantes de uma heróica época medieval, onde os cavaleiros herdaram a disposição de espírito da era gloriosa dos Visigodos, após a conversão ao cristianismo e antes da invasão da península ibérica pelos árabes. Já Vasco representa a decadência dos ideais da cavalaria e acaba vítima dos costumes da nobreza cortesã.

Em contrapartida, Eurico, herdeiro direto da época heróica dos Visigodos na Península, mesmo vivendo numa época decadente, não é molestado pelos vícios do seu

\footnotetext{
${ }^{460}$ Vasco declara para sua irmã: "De sobejo tens pago o erro de um coração inexperto, embora a expiação do criminoso costume ser neste mundo bem longa e severa... E depois, que vamos nós pedir a esse homem? Apenas a reparação de uma afronta, apenas que apague a inscrição vergonhosa que a falsa fé gravou no túmulo de um velho honrado. Não é pedir muito...Oh, eu que fui nobre, que fui cavaleiro; eu, que jamais cometi feito vil, que nunca nos combates voltei as costas, nem alcancei jamais como houvesse quem jamais ajoelhasse aos pés do inimigo a pedir misericórdia, ajoelharei hoje contigo aos pés dele e implorarei, não justiça, mas compaixão. Que a tenha uma vez só, e não a invocaremos mais! (...). Quebrarei os laços do claustro, e iremos viver ambos, esquecidos do mundo e esquecendo-o, no decadente solar de nossos avós. (...)”. Ibidem, p.167.

${ }^{461}$ Ibidem, pp. 70 e 71.
} 
tempo, é apresentado por Herculano como um ser de exceção, um verdadeiro semideus ${ }^{462}$ vivendo entre os homens.

“O período visigótico deve ser para nós como os tempos homéricos da Península"463

Eurico, a narrativa do presbítero godo, surge como uma tentativa de estruturar a forma do romance em Portugal ${ }^{464}$, baseada numa perspectiva da literatura européia do período (narrativas de acontecimentos históricos, romances epistolares e de reflexão interior e a experiência da estética do fragmento do romantismo alemão). Por esses motivos, o romance em questão, que possui uma forma e um acabamento indefinido, pode ser encarado como a concretização dos ideais de Herculano, presentes no Repositório Literário, de renovação da cultura portuguesa a partir de uma literatura de fundo histórico e que faz uma crítica velada à moralidade pública e aos costumes modernos, num diálogo entre passado e presente.

Mesmo criticando o celibato, um dogma ligado a uma "irremediável solidão da alma", como deixa claro Herculano no Prólogo, o romance é todo centrado na idéia de Cristianismo, entendido como mensagem de liberdade, fraternidade e sacrifício ${ }^{465}$, e como condutor do devir histórico ${ }^{466}$, travando um profícuo diálogo como as concepções de filosofia da história do período. Aliás, segundo o crítico Fidelino de Figueiredo, a obra em questão traz uma forte visão idealista não alcançada por nenhuma outra narrativa de Herculano.

\footnotetext{
462 “O meu herói do Críssus é como o último semi-deus que combate na terra; os foragidos de Covadonga são como os primeiros cavaleiros da longa, patriótica e tenaz cruzada da Península contra os Sarracenos". HERCULANO, Alexandre. In: NEMÉSIO, Vitorino. "Eurico - História de um livro".In: HERCULANO, Alexandre. Eurico, O Presbítero. Lisboa: Livraria Bertrand. Edição crítica dirigida e prefaciada por Vitorino Nemésio e apêndices estabelecidos por Maria Helena Lucas. 39ª edição, s/d, p. XXVII.

${ }^{463}$ HERCULANO, Alexandre. Eurico, O Presbítero. Prólogo. São Paulo: Editora Ática, 1999, p.12

${ }^{464}$ Logo no prefácio da obra, Herculano tem dúvidas em categorizar o que escreve, apontando o Eurico como “(...) crônica-poema, lenda ou o que quer que seja (...)”. Idem, p.11.

465 “(...) a mensagem de Cristo, sintetizada nos valores eternos da liberdade e da fraternidade, teria a perenidade bastante para inspirar com segurança o sentido da vida individual e colectiva e para colocar o ideal de Justiça como transhistórico arquétipo do corrente sentido do progresso social e político". CATROGA, Fernando. Op.cit. p. 92.

${ }^{466}$ Herculano mesmo se opondo ao clero muitas vezes, como no caso da contenda expressa no artigo "Eu e o Clero", sempre se afirmou cristão. "Herculano teve uma infância e uma educação cristã, e até 1840 afirmou-se não apenas cristão, mas apologeta. Como poeta, sente-se investido duma missão - ser útil ao Cristianismo - e como publicista empreende uma defesa do Cristianismo numa série de artigos no Panorama em 1838 e 1839. Tudo o que vai publicando até à famosa questão com o clero, em 1850, testemunha a mesma atitude de crença a todo o momento declarada”. TRINDADE, Manuel. O Padre em Herculano. Lisboa: Editorial Verbo, 1965, p.39.
} 
“Obra dum jacto, duma composição precisa, em que nada falta e nada é demais, o Eurico é a forma suprema do poder artístico de Herculano. (...) porque ella traduz o período agudo da epocha idealista da vida de Herculano "467

O plano histórico da narrativa se passa no século VIII no contexto das guerras de invasão dos árabes na Península Ibérica ${ }^{468}$, ou seja, antes da formação da nação portuguesa $^{469}$. Os visigodos, oriundos das tribos germânicas, e conquistadores do território ibérico pertencente aos romanos, são os representantes do cristianismo e da civilização ocidental, porém, apresentados ao leitor como um povo decaído moralmente e corrupto, antecipando as razões porque alguns visigodos irão se aliar aos inimigos islâmicos em troca de riquezas ${ }^{470}$. Situação que tem o intuito de traçar um paralelo com a questão da decadência moral e política de Portugal causada pelas guerras liberais e pela ideologia burguesa/capitalista.

No entanto, ao largo dessa atmosfera de decadência e artificialidade das relações sociais, o "espírito do povo" godo continua preservado em alguns homens, representantes de uma índole pura e de um sentimento de permuta entre a natureza (terra) e a comunidade (leis).

“No meio, porém, da decadência dos godos, algumas almas conservavam ainda a têmpera robusta dos antigos homens da Germânia. Da civilização romana elas não haviam aceitado senão a cultura intelectual e as sublimes teorias morais do cristianismo. As virtudes civis e, sobretudo, o amor da pátria tinha nascido para os godos logo que, assentando o seu domínio nas Espanhas, possuíram de pais a filhos o campo agricultado, o lar doméstico, o templo da oração e o cemitério do repouso e da saudade. Nestes corações, onde reinavam afetos ao mesmo tempo ardentes e profundos, porque neles a índole meridional se misturava com o caráter tenaz dos povos do norte,

\footnotetext{
${ }^{467}$ FIGUEIREDO, Fidelino de. História da Litteratura Romantica (1825-1870). Lisboa: Livraria Clássica Editora, $2^{a}$ edição, 1923, p. 116.

${ }^{468}$ Dialogando com sua narrativa histórica de 1843, ano da publicação no Panorama, Herculano apresenta esse mesmo contexto na História de Portugal - Introdução, de 1846. "As dissenções do império visigótico trouxeram à Espanha os muçulmanos. Estes acabavam de conquistar aquela parte da Á frica do norte a que chamamos Berbéria, do nome dos povos que desde tempos remotos a habitaram". HERCULANO, Alexandre. História de Portugal - Introdução. Lisboa: Editora Ulmeiro, 1980, $1^{\text {a }}$ edição de 1846, p.63.

${ }_{469}$ Para a construção da narrativa, Herculano recorre aos estratagema do manuscrito encontrado, recurso amplamente utilizado pela literatura romântica do período. “(...) porque o pensamento dela foi despertado pela narrativa de certo manuscrito gótico, afumado e gasto do roçar dos séculos, que outrora pertenceu a um antigo mosteiro do Minho" . HERCULANO, Alexandre. Eurico, O Presbítero. Op.cit.. p. 11. 470 "A podridão tinha chegado ao âmago da árvore, e ela devia secar. O próprio clero se corrompeu por fim. O vício e a degeneração corriam soltamente, rota a última barreira”. Idem, p. 14.
} 
a moral evangélica revestia esses afetos de uma poesia divina, e a civilização ornavaos de uma expressão suave, que lhes realçava a poesia" ${ }^{471}$.

O trecho citado acima vai de encontro com a visão de mundo romântica propagada sob o viés das temáticas do "Sturm und Drang" e do Romantismo alemão, como a idéia de "espírito de povo" como constituinte da gênese e da identidade da nacionalidade e de poesia como símbolo de comunhão do particular ("terra"/ "lar doméstico"/ "templo da oração") e do universal ("virtudes civis"/ "amor da pátria").

Um movimento histórico pode ser identificado na passagem da civilização romana para a civilização germânica visigótica, que tem sua gênese identificada com uma tradição pagã e "bárbara", mas mesmo assim, dotada de um "espírito" pulsante e nobre, e que absorve a parcela mais importante e significativa da civilização romana: a cultura e o cristianismo.

“Os visigodos, posto que os mais civilizados entre os povos germano-góticos, conservaram por algum tempo nas suas instituições a linha divisória entre si e os romanos. Por fim essa linha obliterou-se. Facilitados os consórcios entre as duas raças, sujeitos todos os membros da sociedade às leis de um código único, e anuladas as distinções do direito gótico e romano, os habitantes da Península debaixo do nome de godos constiuíam, ao menos nas exterioridades, uma só nação quando a conquista árabe veio confundir ainda mais, se era possível, aquela mistura inextricável de homens de muitas e diversas origens. "472

Assim como a civilização romana entrou em decadência e precisou ser superada, mas com a preservação de algumas características essenciais para a etapa histórica seguinte, a civilização germânica visigótica cristã, também entra num estado de decadência e prepara a sua iminente derrocada.

Sobre a questão da decadência da civilização romana e a preservação de algumas características de sua cultura, um sentido de História baseado em fases de desenvolvimento e dependente dos desígnios da Providência também pode ser identificado na Introdução da História de Portugal, de 1846, de Herculano.

"Grandes historiadores têm desenhado o sombrio e imenso quadro da dissolução do império dos césares. Este resumia toda a civilização antiga; resumia-a e continha-a em si. Essa dissolução havia acabado a tarefa que a Providência lhe destinara na obra

\footnotetext{
${ }^{471}$ Ibidem, p.14.

${ }^{472}$ HERCULANO, Alexandre. História de Portugal - Introdução. Lisboa: Editora Ulmeiro, 1980, $1^{\text {a }}$ edição de 1846, p.45.
} 
do progresso humano. O cristianismo aprofundara já as raízes na terra, vicejava aspergido com o sangue dos mártires, abrigava as sociedades com a sua vasta sombra e, tomando os membros desse caráter gigante que se desconjuntava, já preparando cada um deles para o converter num corpo social cheio de mocidade e de vida.(...). As legiões, a política dos imperadores e a majestade do nome romano serviram por algum tempo de dique à invasão. Fora, porém, Deus que soltara a torrente. Era a luta sublime a da civilização contra a barbaria; mas esta rompeu as barreiras. As hostes e as tribos selvagens do norte arrojavam-se por cima do império: a vaga seguia à vaga. Daquele grande cataclismo nasceram as nações modernas. " 473

Nessa análise nos aproximamos de um esboço de sentido de História ligado à imagem de uma "espiral" 474 , em que a mudança histórica ocorre na preservação de alguns pontos do "espírito do povo" que foi superado como presença (fenômeno) histórica, ou seja, transformando a permanência do caráter íntimo do povo em substrato para a mudança, para a superação histórica ${ }^{475}$.

Sentido de história próximo ao pensamento histórico alemão, na tradição de Herder, onde Hegel definiu de maneira mais estruturada os postulados principais: "Hegel pusera, enfim, o problema do processo pelo qual se realiza esse progresso, esboçara uma teoria da dinâmica histórica, fundada na dialéctica da contradição. $O$ progresso realizar-se-ia por afirmações, contradições e resoluções das contradições; $e$ a sucessão das fases da história da civilização é a materialidade objectiva de uma dialéctica; de uma fase para outra há um nexo lógico. Chega-se assim à noção de uma "lógica da história”, que se objectiva nos factos" ${ }^{476 .}$

Idéia corroborada por Herculano na Carta $V$ das Cartas sobre a História de Portugal: "Se houve uma grande mudança na existência política de um povo, o caracter da geração que foi educada pelas antigas instituições e antigos costumes e que

\footnotetext{
${ }^{473}$ Idem, p.44.

${ }^{474}$ Mesmo negando uma "Filosofia da História", Herculano acaba revelando em seus trabalhos uma preocupação em traçar linhas de entendimento para o conhecimento histórico de Portugal. "Herculano bem sabia que, ao lado da historiografia erudita do seu século, tinham surgido as filosofias da história, as histórias transcendentes de Fichte, Schelling, Hegel, que procuravam obrigar os fatos a entrar em esquemas por eles imaginados ou deduzidos” SILVA, Maria Beatriz Nizza da. Alexandre Herculano O Historiador. Rio de Janeiro: Livraria Agir Editôra, Coleção "Nossos Clássicos", 1974, p.8

${ }^{475}$ Idéia também defendida por Joaquim Barradas de Carvalho: “A mudança permanente, o devir perpétuo da filosofia de Herculano, não é um devir circular em que tudo caminha sempre para o mesmo alvo, passando sempre pelas mesmas fases. É em espiral e, como tal, cada nova fase e cada novo alvo aparecem sempre em estádios novos de desenvolvimento”. CARVALHO, Joaquim Barradas de. As idéias políticas e sociais de Alexandre Herculano. Lisboa: Seara Nova, 1971, p.79. Visão de devir histórico bem semelhante com a de Hegel, onde há um processo lógico e dialético em constante atuação nas várias etapas históricas de cada povo rumo ao Absoluto.

${ }^{476}$ SARAIVA, António José. Herculano e o Liberalismo em Portugal. Op.cit. p. 242.
} 
assistiu a essa transformação, poderá ser modificado por ella, mas conservará sempre os principaes lineamentos que lhe imprimiram as formulas sociaes que passaram" ${ }^{477}$. Ou num trecho da Carta I que ressalta a importância de estudar o passado português: “Na disposição daquelles tenros annos devem-se-lhe achar já os annuncios do vigor da juventude e da idade viril",478.

Os temas centrais do romance analisado de Herculano giram em torno do amor desiludido de Eurico por Hermengarda, motivo causador da escolha do personagem pela vida sacerdotal e pelo celibato ${ }^{479}$, e da invasão dos árabes na Península Ibérica, que servem como elemento analítico desencadeador para a recriação dos costumes do período e para pontuar os aspectos positivos e negativos da gênese do "espírito do povo" português.

Eurico, ao mesmo tempo, poeta, homem apaixonado e guerreiro representa a idéia de cavaleiro medieval idealizado pelo Romantismo ${ }^{480}$ e figura no romance como herói, ou "gênio" romântico. Seu comportamento e suas atitudes, mesmo que superficialmente ligados à paixão por Hermengarda, revelam uma substância maior ${ }^{481}$, uma relação com o "espírito do povo" numa identificação da paixão individual (interesses pessoais) com

${ }^{477}$ HERCULANO, Alexandre. "Carta V" In: "Cartas sobre a História de Portugal". In: Opúsculos Tomo V (Controvérsias e Estudos Históricos - Tomo II). Portugal: Livraria Bertrand, Distribuidora para o Brasil - Editora Paulo de Azevedo, $5^{\text {a }}$ edição, p.138.

${ }^{478}$ HERCULANO, Alexandre. "Carta I" In: "Cartas sobre a História de Portugal". Op.cit. p.40.

${ }^{479}$ Temática discutida no "Prólogo do Autor" e ligada aos destinos trágicos de Eurico e Hermengarda.

${ }^{480}$ Como representante do Romantismo, Herculano toma a Idade Média como momento chave da história portuguesa, chamando a atenção para a base autônoma de algumas instituições medievais em relação ao poder central, como por exemplo, as comunas medievais portuguesas, que proporcionavam um equilíbrio de poderes dentro da sociedade medieval, visão ilustrada, principalmente, no Monge de Cister, e para a volta de alguns princípios gerais do período medieval português que se opunham à visão de mundo burguesa. “(...) no estudo da história pátria cada povo vai buscar a razão dos seus costumes, a sanctidade das suas instituições, os títulos dos seus direitos; se lá vai buscar o conhecimento dos progressos da civilização nacional, as experiencias lentas e custosas, que seus avós fizeram e com as quaes a sociedade se educou para chegar de frágil infância a virilidade robusta; se dessas experiecias e dos exemplos domésticos, desejamos tirar ensino e sabedoria para o presente e futuro (...)" "Nós veremos, para adiante, como através da meia idade, principalmente no século XV, o elemento monarchico foi gradualmente annulando os elementos aristocráticos e democrático, ou, para falar com mais propriedade, os elementos feudal e municipal, annulando-os não como existências sociaes, mas como forças politicas". HERCULANO, Alexandre. "Carta V" In: "Cartas sobre a História de Portugal" . Op.cit. pp. 131 e 132. Assim, como vivia numa sociedade mais justa e aberta à realização do indivíduo, o homem cristão medieval é mais puro, verdadeiro e humano em relação ao homem moderno, guiado por relações sociais assentadas em códigos de conduta artificiais e mundanos.

481 "É esta qualidade de iniciado no mundo do ideal que permite ao poeta dar vida a personagens que não são deste mundo, encarnações do ideal, que reveste forma humana para figurar na parceria dos homens". SARAIVA, António José. Herculano e o Liberalismo em Portugal. Op.cit. p. 139. Sobre o cristianismo diz Eurico: "Tu convertias o amor, esse afeto delicioso, até então limitado ao gozo material da mulher, em sentimento grande e sublime: alargavas o âmbito do coração por toda a terra, por tudo quanto nela vive e respira, e davas-lhe para conquistar todas as existências dos céus. A generosidade, o esforço e o amor, ensinaste-os tu em toda a sua sublimidade: só nas almas dos bárbaros estavam eles em germe. Não para os romanos corrompidos, mas para nós, os selvagens setentrionais, era o cristianismo". HERCULANO, Alexandre. Eurico, O Presbítero. Op.cit. p.28. 
o destino do povo (aspirações mais sinceras, escondidas, no âmago da decrepitude social, política e cultural).

A decadência da sociedade visigótica, apresentada de uma forma mais acentuada com a invasão árabe, impede a realização do verdadeiro destino do povo e Eurico, através de sua alma sensível e agindo intempestivamente, serve de instrumento para a floração dos desejos da parte mais nobre da sociedade visigótica, ocidental e cristã ${ }^{482}$.

Eurico, antes de ser presbítero em Cárteia, foi um valoroso guerreiro da corte de Vítiza, e amigo de Teodomiro, ambos preocupados com a glória das armas ${ }^{483}$ e em cumprir as ordens de seu rei. Até um dia em que nosso personagem é enviado à região da Cantábria, para desbaratar uma rebelião dos montanheses da Vascônia aliados dos francos, e conhece sua amada Hermengarda ${ }^{484}$.

A primeira parte do romance apresenta as inquietações, as angústias mais secretas e as confissões ${ }^{485}$ do presbítero de Cartéia, situação impulsionada pela recusa do duque de Cantábria, Favila, pai de Hermengarda, em aceitar o amor de Eurico pela jovem donzela. Eurico é apresentado como um solitário, que prefere caminhar sob a escuridão da noite do que viver próximo aos homens, um poeta em comunhão com a natureza e em busca de um sentido para sua existência, ou seja, um personagem romântico que caberia em qualquer obra do "Sturm und Drang" ou do Romantismo alemão ${ }^{486}$.

\footnotetext{
${ }^{482}$ Sobre Eurico: “(...) não percebiam como, tranquila a consciência e repousada a vida, um coração pode devorar-se a si próprio, e os maus não criam que o sacerdote, embebido unicamente em suas esperanças crédulas, em suas cogitações de além túmulo, curasse dos males e crimes que roíam o império moribundo dos visigodos; não criam que tivesse um verbo de cólera para amaldiçoar os homens aquele que ensinava o perdão e o amor. Era por isso que o poeta escondia as suas terríveis inspirações. Monstruosas para uns, objeto de ludíbrio para outros, numa sociedade corrupta, em que a virtude era egoísta e o vício incrédulo, ninguém o entenderia" HERCULANO, Alexandre. Eurico, O Presbítero. Op.cit. p. 21.

483 "A glória era o seu perpétuo sonho, e as recordações das façanhas dos antigos godos embriagavamlhes os ânimos ao lembrarem-se de que as armas dos seus avós da Germânia tinham brilhado vitoriosas sempre sobre os membros despedaçados do império romano". HERCULANO, Alexandre. Eurico, $\mathbf{O}$ Presbítero. Op.cit. p. 37.

484 "Debalde buscou Teodomiro apagar aquela paixão violenta no coração do seu amigo, lançando-se com ele nas festas ruidosas de uma corte dissoluta. A embriaguez dos banquetes era pra Eurico tristonha; as carícias feminis, facilmente compradas e profundamente mentidas, atrás das quais correra loucamente outrora, tinham-se-lhe tornado odiosas; porque o amor, com toda a sua virgindade sublime, lhe convertera em podridão asquerosa os deleites grosseiros que o mundo oferece à sensualidade do homem. Teodomiro acreditava na eficácia da bruteza para matar o mais formoso dos afetos humanos; mas o amor devorou na mente de Eurico todos os outros sentimentos, como a lava candente devora tudo o que encontra, quando o vulcão a vomita, alagando a superfície da terra”.Idem, p.38.

485 "Repare-se: confissões e não memórias. Quer dizer: discurso descontínuo, apaixonado e subjetivo, não reflexão estritamente cronológica sobre toda uma vida historicamente situada: discurso da aparência inserida no instante fugitivo, que no "dizer tudo" a si mesmo se põe em causa, procurando uma verdade interior múltipla” MACHADO, Álvaro Manuel. As origens do Romantismo em Portugal. Lisboa: Livraria Bertrand, Coleção Biblioteca Breve, volume 36, 1979, p. 24.

486 “Excepcional e solitário, guia obscuro da humanidade, tardio descendente da raça dos magos, dos profetas e dos videntes, e, sobretudo decifrador da Natureza, que por ele se deixa ler como um livro
} 
"O povo rude de Cartéia não podia entender esta visão de exceção, porque não percebia que a inteligência do poeta precisa viver num mundo mais amplo do que esse a que a sociedade traçou tão mesquinhos limites" "487. A expressão "visão de exceção" citada para caracterizar Eurico, também pode ser usada, na mesma proporção, para todos os personagens românticos. A visão de mundo de Eurico foge daquela esperada pela lógica da realidade ao seu redor, e repousa na utopia da comunhão dos cristãos num novo tempo.

De acordo com a ótica romântica, a nostalgia e, em certo sentido, a espera de uma etapa histórica superior para as relações humanas, nascem porque “(...) no real moderno, algo de precioso foi perdido, simultaneamente, ao nível do indivíduo e da humanidade. A visão romântica é caracterizada pela convicção dolorosa e melancólica de que o presente carece de certos valores humanos essenciais que foram alienados ${ }^{\prime 488}$.

Mesmo afastado dos homens por razões de espírito e de entendimento do mundo, Eurico quer retomar "aquilo de precioso que foi perdido" e resgatar a sociedade da decadência moral que se adentrou e ajudar na tarefa de recondução da humanidade ao caminho do espírito do Cristianismo ${ }^{489}$, finalidade última no destino humano, num resgate da temática religiosa do "Pároco da Aldeia".

“Mas Eurico era como um anjo tutelar dos amargurados. Nunca a sua mão benéfica deixou de estender-se para o lugar onde a aflição se assentava; nunca os seus olhos recusaram lágrimas que se misturassem com lágrimas alheias desventuras. Servo ou homem livre, liberto ou patrono, para ele todos eram filhos. (...) Eurico percebera, enfim, claramente que o cristianismo se resume em uma palavra - fraternidade. Sabia que o evangelho é um protesto, ditado por Deus para os séculos, contra as vãs distinções que a força e o orgulho radicaram neste mundo de lodo, de opressão e de sangue; sabia que a única nobreza é a dos corações e dos sentimentos que buscam

aberto, detentor de verdades inacessíveis à maioria de que se dessolidariza, sentindo-se mais próximo, pela atividade não-utilitária, não- produtiva, e pela sua dependência à imaginação, das crianças e dos loucos, (...)”. NUNES, Benedito. Op.cit. p. 72.

${ }^{487}$ HERCULANO, Alexandre. Op.cit. p. 19.

${ }^{488}$ LOWY, Michel e SAYRE, Robert. Revolta e Melancolia - O romantismo na contramão da modernidade. Petrópolis, Rio de Janeiro: Editora Vozes, 1995, p.40.

489 "A poetização da religião é, no entanto parte de um processo geral de poetização da vida, que o movimento romântico impulsionou. Metáfora integrante da visão romântica, o florescimento do Espírito e da Natureza - do Eu transcendente e da Natureza orgânica - produz-se na arte, sobre os ramos da metafórica árvore da vida, a imagem de uma plenitude originária perdida e de uma perfeição futura a conquistar - árvore que nasce interiormente, e cujas raízes espirituais se fixam no subsolo da imaginação”. NUNES, Benedito. Op.cit. p. 64. 
erguer-se para as alturas do céu, mas que essa superioridade real é exteriormente humilde e singela" ${ }^{\text {, }} 90$.

Inúmeras passagens do romance são ilustradas com descrições da natureza, presentes nas cartas de Eurico, que mostram uma similaridade, bem ao gosto da estética romântica, com os sentimentos e o universo interior do personagem central ${ }^{491}$. Uma natureza vivaz e fora da relação utilitarista traçada pela sociedade capitalista burguesa, uma força pulsante e reencantada ${ }^{492}$ se faz notar em todos os momentos de desvendamento da alma de Eurico.

A natureza e a noite ${ }^{493}$, locais encarados pelos românticos como espaços de sonhos e de fantasias que se opõem aos interesses mesquinhos e egoístas dos homens, são apresentados como forças análogas aos sentimentos humanos e, desse modo, uma opção estética para universalizar a voz interior dos personagens românticos ${ }^{494}$.

"Por que te havia eu de amar, ó sol, se tu és o inimigo dos sonhos do imaginar; se tu nos chama à realidade, e a realidade é tão triste? Pela escuridão da noite, nos lugares ermos e às horas mortas do alto silêncio, a fantasia do homem é mais ardente e robusta" ${ }^{495}$.

O crítico Benedito Nunes definiu bem essa intrínseca relação de dependência do homem romântico e da Natureza, onde o humano torna-se representação autêntica do Espírito ao desvendar uma "intuição panteísta" ou "unidade primordial" no mundo real e a Natureza transforma-se em manifestação de Deus.

\footnotetext{
${ }^{490}$ HERCULANO, Alexandre. Eurico, O Presbítero. Op.cit. p. 19. A idéia de comunhão entre os homens e de exigência da comunidade para os românticos, pode ser sentida em Herculano na sua valorização das comunas medievais que, além de dividir e equilibrar o poder político na sociedade medieval portuguesa, também servia de modelo de utopia para a sociedade liberal burguesa da sua contemporaneidade.

491 "O descritivo de Herculano pretende constantemente sugerir apelos do ideal; como na população dos seus romances se infiltram por personagens escapadas do céu ou do inferno”. SARAIVA, António José. Herculano e o Liberalismo em Portugal. Op.cit. p.151.

492 “(...) o romantismo aspira ao reencantamento da natureza. É o papel da filosofia religiosa da natureza de um Schelling de um Ritter ou de um Baader, mas é também um tema inesgotável da poesia e pintura românticas que não deixam de procurar as analogias misteriosas e as "correspondências" - (...) - entre a alma humana e natureza, espírito e paisagem, tempestade interna e externa”. LOWY, Michael e SAYRE, Robert. Op.cit. p. 54.

${ }^{493}$ Não podemos esquecer a influência dos "sentimentalistas ingleses" para a temática da "noite", absorvida por Herculano através de suas leituras: "Mas é sobretudo Young, com The Nights, que leva a um extremo de obsessão e de originalidade a imagem da noite, ao mesmo tempo que a torna uma expressão absoluta do destino pessoal e da reflexão metafísica” MACHADO, Álvaro Manuel. Op.cit. p. 33.

494 “Era por uma destas noites vagarosas do inverno em que o brilho do céu sem lua é vivo e trêmulo; em que o gemer das praias e ribas fragosas do oceano é absoluta e tétrica" "Lá, o sopro gelado da noite não fazia confranger nossos avós debaixo das armaduras. Lá, a neve era uma leito como outro qualquer, e o rugir do bosque, debatendo-se nas asas da tempestade, era uma cantilena de repouso"

HERCULANO, Alexandre. Eurico, O Presbítero. Op.cit. pp.23 e 24.

${ }^{495}$ Idem, p. 29.
} 
"Para o poeta romântico, as formas naturais com que ele dialoga, e que falam à sua alma, falam-lhe de algum outra coisa; falam-lhe do elemento espiritual que se traduz nas coisas, ao mesmo tempo signo visíveis e obras sensíveis, atestando, de maneira eloquente, a existência onipresente do invisível e do supra-sensível. A Natureza transforma-se numa teofania. Os bosques, as florestas, o vento, os rios, o amanhecer e o anoitecer, os ruídos, os murmúrios, as sombras, as luzes - de tudo o que não é humano e se constitui em espetáculo para o homem" ${ }^{496}$.

O Romantismo, como crítico da modernidade capitalista, pode ser identificado, igualmente, no romance histórico de Herculano. Todo o movimento de isolamento, de recusa aos valores sociais e de melancolia, a "tempestade interna" de Eurico, foi desencadeado por uma típica recusa burguesa. O pai de Hermengarda, Favila, não aceita a união dos dois amantes, por preferir um partido mais rico, poderoso e da mesma condição social para a filha, ou seja, julga Eurico pela sua condição material e não por seus valores morais de guerreiro e de homem sensível ${ }^{497}$, fazendo com que nosso personagem reprima sua paixão e opte pela vida monástica.

Mesmo arrasado pelo amor rejeitado e melancólico, Eurico cumpre o seu papel de "gênio", de homem de exceção, e em sonho prevê a invasão e a conquista dos árabes na Península, revelando ainda mais a presença da idéia de devir histórico de Herculano na narrativa.

“Senhor, Senhor! Foste tu que deste a ler à minha alma a última página do livro eterno em que a Providência escreveu a história do império godo?

Contam-se coisas incríveis desses povos que assolam a África, chamados os árabes, e que, em nome de uma crença nova, pretendem apagar na terra os vestígios da cruz. Quem sabe se aos árabes foi confiado o castigo desta nação corrupta?

Já as nossas praias foram visitadas por eles, e para os repelir cumpriu que desembainhasse a espada o ilustre Teodomiro, o último guerreiro, talvez, que mereça o nome de neto dos godos.

Terra em que nasci, se o teu dia de morrer é chegado, eu morrerei contigo. (...) $)^{\text {498 }}$.

\footnotetext{
${ }^{496}$ NUNES, Benedito. Op.cit. p. 65.

${ }^{497}$ Eis a fúria de Eurico: "Porque mulher bárbara não entendeu o que valia o amor de Eurico; porque velho orgulhoso e avaro sabia mais um nome de avós do que eu, e porque nos seus cofres havia mais alguns punhados de ouro do que nos meus". HERCULANO, Alexandre. Op.cit. p.32.

${ }^{498}$ Idem, p. 37.
} 
Com o anúncio da guerra iminente, Eurico torna-se o antigo guerreiro da corte de Vítiza, potencializado pela dor do claustro e da melancolia.

"Não, eu não quero a glória inútil e ininteligível hoje para mim. Não, eu não quero o mando e o poderio, porque já não sei para o que eles prestam. Como o febricitante em dia ardente de estio, que aspira a brisa da tarde, a qual não pode sará-lo, mas que refrigera por momentos o ardor de sangue, assim eu ainda me deixo afagar pela idéia de me atirar ao maior fervor das batalhas pelejadas em nome da pátria. Esse delírio dos perigos; essa loucura que o cheiro de sangue produz é um respiradouro por onde resfolegará a indignação e a cólera entesourada por anos neste coração" 499.

A segunda parte do romance é pautada pela luta da resistência visigótica contra os invasores árabes, com descrições detalhadas de batalhas e dos costumes dos dois povos inimigos, revelando aspectos positivos e negativos dos visigodos e dos seus oponentes, como a traição de Juliano e do bispo Opas e a coragem de Pelágio, irmão de Hermengarda e líder da resistência de Covadonga.

A Batalha do Críssus, no Calpe ${ }^{500}$, que definiu a bem sucedida invasão árabe na Península, é descrita minuciosamente por Herculano, onde desfilam personagens históricos reais e fictícios, tanto do lado visigótico quanto árabe. Teodomiro, Pelágio e Roderico combatiam ao lado do Cavaleiro Negro contra as forças árabes de Tarik e Muguite e contra os traidores Juliano, Opas, o bispo de Híspalis e os filhos de Vítiza, Sisebuto e Ebas ${ }^{501}$.

Momento histórico também caracterizado na História de Portugal:

"Musa Ibn Nosseyr, nomeado amir de África pelo califa de Damasco (702), soube atrair a maior parte deles ao islamismo e pacificá-los. Septum, a moderna Ceuta, com o território vizinho era desde o tempo dos romanos uma dependência da Espanha, e os visigodos haviam-na conservado unida à monarquia. $O$ amir tentara apossar-se daquela cidade, mas fora repelido pelo conde Juliano que a governava em nome de Witiza. Daí a pouco este foi derrubado do trono, segundo parece por uma conspiração,

\footnotetext{
${ }^{499}$ Ibidem, p.46.

${ }^{500}$ Cidade da Bétia junto ao monte do mesmo nome. Designação por que era tomada a moderna Gibraltar antes da vinda dos Árabes a Espanha. LUCAS, Maria Helena. In: HERCULANO, Alexandre. Eurico, 0 Presbítero. Lisboa: Livraria Bertrand. Edição crítica dirigida e prefaciada por Vitorino Nemésio e apêndices estabelecidos por Maria Helena Lucas. 39ª edição, s/d, p.330

501 "Tárique lançara na frente da hoste muçulmana os trânsfugas do inimigo. Sisebuto, Ebas, o bispo de Híspalis e o conde de Septum com os seus numerosos guerreiros constituíam a vanguarda.(...).

Roderico pela sua parte, tinha posto na vanguarda as tiufadias vitoriosas de Teodomiro, os cavaleiros da Cantábria guiados pelo moço Pelágio, filho de Favila, que sucedera a seu pai no governo daquela província, e, finalmente, os guerreiros escolhidos da Lusitânia e da Galécia, que ele próprio capitaneava.”. Ibidem, p. 61.
} 
na qual entrava Ruderico ou Rodrigo que lhe sucedeu (709). Witiza deixava dois filhos que procuraram, ou pública ou secretamente, arrancar a coroa àquele que consideravam como usurpador. Juliano associou-se a esta nova conjuntura e solicitou os socorros de Musa, abrindo-lhe as portas de Ceuta e incitando-o a enviar uma expedição à Península. (...) o amir enviou um exército de doze mil homens composto em grande parte de africanos e capitaneado por Tarik Ibn Zeyad, seu lugar-tenente no governo do Moghreb (Mauritânia). Juliano acompanhava os muçulmanos, e a expedição aportando nas raízes do Calpe,esperou, fortificando-se ali, os reforços que brevemente the chegaram. (...). .Pouco tardou o general muçulmano a entranhar-se na Península, e enquanto Ruderico ajuntava forças para se lhe opôr ele assolava as províncias do sul desbaratando as partidas de godos que intentavam obstar às suas correrias. Afinal os dois exércitos encontraram-se nas margens do Chryssus ou Guadalete. Deu-se uma batalha, àcerca de cujas circunstâncias se lêm nos historiadores árabes e cristãos as narrações mais encontradas. É, porém, indubitável que esta jornada foi decisiva e que nela se fez em pedaços o império visigótico. Os godos ficaram completamente destroçados, e Ruderico, segundo parece, pereceu no conflito" ${ }^{502}$.

Os temas da paixão, do herói e do sacrifício aparecem em todo o romance, mas é na segunda parte que os mesmos ganham maior destaque e relevância na relação com as premissas estéticas do "Sturm und Drang" e do Romantismo alemão.

A paixão de Eurico, entendida num sentido mais amplo de comunicação com o "espírito do povo", revela-se na figura do cavaleiro negro, guerreiro impiedoso e que luta como uma verdadeira força da natureza, e exemplo de bravura para a resistência goda, que nos momentos de fraqueza e perigo, deixa ser guiada pela fúria misteriosa do cavaleiro negro ${ }^{503}$.

O cavaleiro negro é apresentado para os leitores como um símbolo de paixão particular do herói, como aquele que deseja o bem de sua comunidade e de sua bem amada, e de paixão universal, concentrando os anseios do povo, a parte mais nobre e verdadeira da decaída sociedade cristã visigótica. O cavaleiro negro durante toda a

\footnotetext{
${ }^{502}$ HERCULANO, Alexandre. História de Portugal - Introdução. Lisboa: Editora Ulmeiro, 1980, $1^{\text {a }}$ edição de 1846, pp. 63 e 64.

503 "Como um rochedo pendurado sobre as ribanceiras do mar, que, estalando, rola pelos despenhadeiros e, abrindo um abismo, se atufa nas águas, assim o cavaleiro desconhecido, rompendo por entre os godos, precipitou-se para onde mais cerrado em redor de Teodomiro e Muguite fervia o pelejar. (...). Animados por ele, os godos, cobrando novos brios, procuravam imita-lo e arremessavam-se destemidos através da hoste inimiga, que debalde procurava resistir à torrente” HERCULANO, Alexandre. Eurico, O Presbítero. Op.cit. pp. 58 e 59.
} 
guerra, não mostra sua identidade, porque deve ser confundido com qualquer um, deve representar o todo, natureza e comunidade, o último alento do "espírito do povo" $\operatorname{godo}^{504}$.

Para Herculano, o tema da liberdade do indivíduo ${ }^{505}$, máxima niveladora de toda ação política, ganha contornos simbólicos na figura do cavaleiro negro, que luta para garantir a autonomia política e espiritual de tudo aquilo representado pelo povo godo, a civilização ocidental e o cristianismo. Desse modo, podemos relacionar o culto da paixão, em toda sua dimensão e profundidade, com o culto da liberdade política, defendida em toda a vida pública de Herculano, representante ímpar do pensamento liberal português.

A importância da ação dos indivíduos dentro dos rumos dos acontecimentos históricos também pode ser relacionada à Pelágio, irmão de Hermengarda, e Teodomiro, amigo de Eurico. Tanto um quanto o outro simbolizaram a tentativa de resistência dos visigodos diante dos árabes, já num segundo momento da invasão, onde os inimigos foram comandados por Abdu-1-aziz, filho do amir Musa.

A figura de Teodomiro é ressaltada na História de Portugal ${ }^{506}$, e também lembrada no romance ${ }^{507}$, mas Eurico, símbolo máximo da paixão e do irracionalismo romântico, condena, veementemente, a atitude do amigo por esse ter estabelecido um acordo de paz com os árabes.

\footnotetext{
504 "Eurico era a última e tenuíssima esperança que bruxuleava nos horizontes do império godo: como estrela cadente que se imerge nos mares, aquele esforço brilhante se desvanecera na escuridão que tingia as águas do Críssus!”. Idem, p.66.

${ }^{505}$ Para o pesquisador Jorge Borges de Macedo, os personagens de Herculano obedecem um "intimismo agressivo" e nas narrativas históricas há uma “(...) profunda desconfiança das razões gerais e sociais, o apelo constante ao que há de pessoal e de íntimo em cada acto humano". MACEDO, Jorge Borges de.
} Alexandre Herculano - Polêmica e Mensagem. Prêmio de Ensino Alexandre Herculano 1977/78, Portugal: Livraria Bertrand, 1980, p. 24.

506 “Abdu-l-aziz, tendo neste meio tempo submetido de novo Sevilha, dirigira-se para o sueste da Península ainda não subjulgado. Teodomiro, célebre capitão godo e duque ou governador duma parte da Bética, havia-se retirado para ali depois da batalha de Guadalete com os restos do exército e formara um como simulacro da monarquia gótica no território das modernas províncias de Murcia e Valencia. Por muito tempo o esforçado Teodomiro resistiu a Abdu-l-aziz; mas desbaratado nas planícies de Lorca, onde fôra constrangido a aceitar com forças inferiores uma batalha campal, acolheu-se com as relíquias das suas tropas a Orihuela (Auriola). Sitiado pelos sarracenos viu-se reduzido, depois de brava resistência, a aceitar o jugo muçulmano, posto que com vantajosas condições, sendo reconhecido por príncipe dos godos, mas tributário, nos distritos que dantes regia”. HERCULANO, Alexandre. História de Portugal - Introdução. Lisboa: Editora Ulmeiro, 1980, $1^{\text {a }}$ edição de 1846, p.65.

507 “As relíquias do exército godo que não haviam podido resistir a Tárique, muito menos poderiam impedir a passagem do amir. Assim, Teodomiro, ajuntando esses soldados dispersos, acolhera-se às serranias de Ilipula, na extremidade oriental da Bética. Muça, porém enviara contra ele seu filho Abdulaziz, um dos mais famosos guerreiros do Islame. Apesar da superioridade do exército árabe, a luta fora longa e terrível. Teodomiro sucumbira por fim;mas, posto que vencido, o seu valor obrigara os muçulmanos a concederem-lhe vantajosas condições de paz.”. HERCULANO, Alexandre. Eurico, $\mathbf{O}$ Presbítero. Op.cit. p. 83. 
"Foi porque eu o cria um anjo de virtude e esforço, e ele era apenas um homem! Foi porque a paz que pactuou com os muçulmanos, honrosa aos olhos do vulgo, era, a meus olhos infâmia. Paz com o infiel? Ao cristão só cabe fazêe-la quando dormir ao lado dele sono perpétuo no campo de batalha; quando, ao lado um do outro, esperarem ambos que as aves do céu venham banquetear-se em seus cadáveres. (...). Nesse momento algumas lágrimas correram destes olhos; porque a alma de Teodomiro era a última em que morava um afeto que respondesse aos meus: era o último templo em que me sorria a esperança!" 508 .

Já Pelágio, líder da resistência goda em Covadonga, que tem uma provável origem histórica não condizente fielmente com o romance ${ }^{509}$, mas aproveitado por Herculano por representar a luta contra o invasor árabe, é representado como um guerreiro corajoso e fiel aos velhos preceitos de honra dos guerreiros visigóticos. Valores renovados por uma imbatível disposição de espírito em prol da luta pela liberdade.

"Poucos o haviam seguido naquela vida quase selvagem: mas esses poucos eram homens a quem a aura da liberdade parecia a única atmosfera em que os pulmões robustos poderiam resfolegar; homens a cujos olhos as afrontas da cruz derribada do cimo das catedrais seria espetáculo incrível e insuportável. Uma caverna servia de paço ao jovem rei das montanhas e de templo ao Crucificado. Os domínios de Pelágio eram as serranias e os vales profundos onde, porventura, até então nunca soara a voz. humana. (...). Às vezes, Pelágio e os seus soldados desciam das montanhas para largas correrias, semelhantes à tempestade noturna, e, como a tempestade, passavam pelas

\footnotetext{
${ }^{508}$ Idem, p.87.

509 “A Crónica Albeldense supõe-no filho de Veremundo ou Bermudo, e sobrinho de Rodrigo. Sebastião de Salamanca, que viveu à roda de 883, diz que foi filho de Favila. A Crónica de Oviedo designa-lhe nascimento nos Duques de Alava. Contrariando esta ascendência ilustre, afirma-se, por outro lado, que era um hispano-romano, de condição humilde. Realmente os autores árabes, ao referirem-se a ele, chamam-lhe sempre Belay ou Belaz-al-Rumi, o que parece querer dizer: Pelaio, o Romano.

Refugiado em Covadonga, cedo a galhardia do cavaleiro unida à presumível nobreza de sangue o elevaram a chefe de algumas regiões do Sul e do Centro da Península. Diz a lenda que Munuza, governador de Gijón, se enamorou de uma irmã do jovem rei e a raptou, deixando em seu lugar a ira acesa do guerreiro, que, para vingar o ultraje, levou os soldados das Astúrias à guerra aos infiéis. É provável que Herculano, conhecedor deste episódio, que, se peca por menos verdadeiro, ganha em imaginoso e subtil, o tivesse aproveitado no romance, conduzindo Hermengarda ao harém de Abdulaziz.

Em 718 Pelágio estava vencedor em Covadonga. Depois desta vitória dedicou-se a robustecer o seu pequeno reino, que governou durante 19 anos. Morreu em Cangas, no ano de 737”. LUCAS, Maria Helena. In: HERCULANO, Alexandre. Eurico, O Presbítero. Lisboa: Livraria Bertrand. Edição crítica dirigida e prefaciada por Vitorino Nemésio e apêndices estabelecidos por Maria Helena Lucas. $39^{a}$ edição, s/d, p.334. "Pelágio foi o capitão destes godos refugiados nas Astúrias e o fundador da primeira monarquia cristã de Espanha, depois chamada de Oviedo e Leão.” HERCULANO, Alexandre. História de Portugal - Introdução. Lisboa: Editora Ulmeiro, 1980, $1^{\text {a }}$ edição de 1846, p.65.
} 
tendas dos árabes ou pelas aldeias, despovoadas de cristãos, onde os infiéis começavam a fazer assento" ${ }^{510}$.

Após a batalha de Críssus, Eurico, como cavaleiro negro e símbolo da liberdade individual romântica, se junta a Pelágio para resgatar Hermengarda, aprisionada na invasão árabe no Mosteiro da Virgem Dolorosa e escolhida por Abdulaziz para ser uma de suas esposas, e na tentativa final de vitória contra os invasores.

A ação do indivíduo, máxima do pensamento romântico de Herculano, e desse modo, tema central de seus romances históricos, é definido pelo pesquisador Jorge Borges de Macedo com estas palavras: "Na sua hermenêutica crítica, no pensamento político, na interpretação histórica e na narrativa romanesca, o colectivo e o abstrato são até factores susceptíveis de perturbar e enfraquecer o poder criador. Este reside essencialmente no acto pessoal. É o motor da História e das sociedades e até a sua justificação. As sociedades existem para "receber" o acto pessoal e dar-lhe sentido público. (...). A sociedade, para Herculano, deve conceber-se - e portanto preparar-se - com esse projecto: ela será tanto mais perfeita quanto melhor permitir a realização do homem. (...) Nunca poderá visar substituir a vida pessoal pela colectiva "511.

As duas temáticas do romance de Herculano, o culto da paixão e da liberdade, atos dependentes e norteadores do indivíduo, analisadas sob o viés do Romantismo, configuram-se para Max Weber, em sentenças relacionadas a uma "doação de si sem limites" que acaba se tornando "tão radical quanto possível em sua oposição a toda funcionalidade, racionalidade e generalidade" ${ }^{, 512}$.

Seguindo nessa mesma idéia, podemos dizer que o personagem romântico Eurico, é um apaixonado por essência, devido à defesa sem limites de sua individualidade que não consegue se realizar plenamente na sociedade visigótica moralmente decaída, por isso luta e se sacrifica, sem saber, em prol de uma nova etapa na formação de seu povo.

Eurico é o porta-voz da Providência, o "gênio" romântico, aquele que resgata o verdadeiro "espírito do povo" godo, e com seus exemplos e ações individuais, inspira novas gerações e conduz o devir histórico. Como o próprio cavaleiro negro deixa transparecer na sua conversa com Pelágio, pedindo para que esse ficasse em segurança em Covadonga e permitisse que ele salvasse Hermengarda dos árabes.

\footnotetext{
${ }^{510}$ HERCULANO, Alexandre. Eurico, O Presbítero. Op.cit. p.82.

${ }^{511}$ MACEDO, Jorge Borges de. Op.cit. p. 25.

${ }^{512}$ LOWY, Michel e SAYRE, Robert. Op.cit. p.43.
} 
“- Por minha boca falaram milhares de godos que gemem no cativeiro e que voltam de contínuo os olhos para os cerros das Astúrias, onde apenas fulgura tênue o santo fogo da liberdade: falaram por minha boca as aras do Senhor calcadas pelos pés dos pagãos, as imagens de Cristo derribadas no lodo, os muros enegrecidos das cidades incendiadas. É isto tudo que voz diz: - não saireis daqui! - Perguntas quem sou? Dir-to-ei. O último homem que, junto do Críssus, viu, combatendo, a face dos árabes vencedores, enquanto os valentes fugiam; o homem que tentou morrer com a pátria, e que a mão de Deus salvou para neste momento vos dizer: não saireis daqui! $(\ldots)^{, 513}$.

No bojo dessas questões, uma hipótese ligada à caracterização de Eurico, é seu papel de herói "histórico-universal" e "instrumento da História", nas concepções da Filosofia de História de Hegel. Que para o filósofo alemão, a tarefa do "herói” seria necessária nos momentos que a civilização constituída por um povo entrasse num período de decadência e, ao mesmo tempo, de transição. Deste modo, o herói, subordinado aos costumes passaria a desempenhar, através de suas ações ou criações artísticas, o sentido de História de seu povo, motivado por razões individuais, mas impulsionado, de maneira oculta, pelos desígnios da Razão Absoluta ${ }^{514}$.

Próximas a constatação do arcabouço romântico dos personagens de Herculano está a seguinte idéia de Jorge Borges de Macedo: "Para Herculano todas as manifestações colectivas passam necessariamente pelos indivíduos que nelas participam. Ao mesmo tempo, o eco público da acção individual tem maior ou menor receptividade, conforme a autenticidade e a violência do sentir pessoal e o relevo de quem executa: a sociedade é movida pelas vontades constantes, determinadas e fortes. São assim as figuras dos seus romances e novelas; são-no também os seus heróis históricos e a figuração política que toma por mais representativa" ${ }^{215}$.

O final do romance é centrado no episódio da salvação de Hermengarda e na batalha final de Eurico, o cavaleiro negro.

No momento que Abdulaziz perde a paciência com sua cativa e inicia uma atmosfera de tensão sexual com Hermengarda, surge o salvador, o cavaleiro negro.

\footnotetext{
${ }^{513}$ HERCULANO, Alexandre. Eurico, O Presbítero. Op.cit. p. 91.

${ }^{514}$ A deferência de Pelágio pelo cavaleiro negro é símbolo do verdadeiro significado do herói da narrativa: "Devemos obedecer-te, se és um homem, como dizes, porque vales mais que nós. Se és o anjo que preside aos fados da Espanha, mais submisso ainda será o nosso obedecer.” Idem, p. 91.

${ }^{515}$ MACEDO, Jorge Borges de. Op.cit. p. 27.
} 
“No seu furor, o filho de Muça não sentira um rugido de cólera que respondera ao grito de Hermengarda, nem um ai passageiro e sumido, que, segundo era íntimo, parecia de homem a quem a ponta de um punhal rasgara subitamente o coração. Nas telas, porém, que dividiam o aposento do lugar de onde pouco antes saíra o eunuco e que ficavam fronteiras à entrada principal da tenda uma figura humana se estampou negra sobre o chão brilhante da tapeçaria. O amir, volvendo casualmente os olhos, a viu. Crescia rápida. Escutou. Passos ligeiros soavam no vasto aposento. Voltou-se. Mas apenas pôde erguer o braço: vira reluzir no ar um ferro: vira um vulto coberto de armas semelhantes às dos cavaleiros de Açudane: sentiu um golpe que lhe partia o braço erguido e que, batendo-lhe ainda no crânio, lhe retumbava o cérebro. Deu um grito, fechou os olhos e caiu aos pés de Hermengarda, (...). As palavras - "liberdade e Pelágio" - proferidas por ele, tinham calado como um bálsamo de vida no coração de Hermengarda. O desconhecido, tomando-a nos braços, atravessou ligeiro para o lado do arraial onde estanceavam os godos $" 516$.

Após revelar a sua dupla identidade, de cavaleiro negro e presbítero de Cartéia para sua amada, e depois de um breve momento de alegria vivida por Eurico e Hermengarda ao descobrirem que se amavam mutuamente ${ }^{517}$, Hermengarda cai desfalecida por tomar conhecimento da impossibilidade da união com seu amado, e Eurico investe num ataque suicida contra os árabes. Nosso personagem morre infeliz, mas completa a missão de sua existência, ser símbolo do Infinito ${ }^{518}$.

"Ora, para além da morte como desfecho natural, o destino concreto de cada povo poderia ser acelerado ou adiado em função do comportamento ético dos indivíduos que o compõem" ${ }^{\text {519. }}$.

\footnotetext{
${ }^{516}$ HERCULANO, Alexandre. Eurico, O Presbítero. Op.cit. p. 99.

${ }^{517}$ Hermengarda: "O repentino impulso da sua alma foi lançar-se nos braços de Eurico. Fora ele o objeto do seu quase infantil e único amor, amor condenado ao silêncio antes do primeiro suspiro, antes do primeiro volver de olhos; era o cavaleiro negro, cujo nome se tornara conhecido e glorioso por todos os ângulos de Espanha; era ele, finalmente, o homem que duas vezes acabava de salvá-la". Eurico: "Oh, como é bom ser feliz!...Tinha-me também esquecido! Tens razão, Hermengarda. Quero viver: o viver é delicioso, delicioso porque será contigo...a a pé de ti... a adorar-te sempre, sem me lembrar do que existe, além de ti, no universo. Vem, minha amante, minha esposa!". HERCULANO, Alexandre. Eurico, $\mathbf{O}$ Presbítero. Op.cit. p. 134.

518 "Aquele sobressalto, tão impensado, revocou o cavaleiro ao sentimento da sua situação. Ajoelhou junto de Hermengarda e, pegando-lhe na mão já fria, beijou-lha. Nas raias da vida, aquele beijo, primeiro e último, era purificado pelo hálito da morte que se aproximava: era inocente e santo, como o de dois querubins ao dizer-lhes o Criador: "- Existi!". "Depois ergueu-se, vestiu a sua negra armadura, cingiu a espada, lançou mão do franquisque e, rompendo por entre o tropel, que fizera silêncio ao vê-lo, desapareceu através da porta da gruta, cujas rochas tingia cor de sangue a dourada vermelhidão da aurora" HERCULANO, Alexandre. Eurico, O Presbítero. Op.cit. p. 137.

${ }^{519}$ CATROGA, Fernando. Op.cit. p. 97.
} 
O herói romântico tem sua alma apontada para o Universal, num destino trágico, e por esse motivo, sua existência como um todo acaba sendo alvo do embate entre finito e infinito. No caso do romance histórico de Herculano, Eurico possui sentimentos mais sinceros e intensos que os outros homens e, portanto, vive uma vida completamente deslocada de uma realidade medíocre e mundana ${ }^{520}$, pautada pela dor, abnegação e infelicidade, mas única capaz de suportar todos os encargos do sublime ${ }^{521}$.

\section{Conclusão:}

Após o percurso dos capítulos apresentados, podemos dizer que Alexandre Herculano, um dos introdutores do Romantismo em Portugal ao lado de Almeida Garrett, foi um profícuo e eclético captador de concepções e idéias tanto da estética romântica quanto do chamado historicismo romântico.

Sua obra, herdeira em certo ponto da reflexão dos ilustrados portugueses, soube captar as principais tendências políticas, econômicas, sociais e culturais, do pensamento e da ação do liberalismo português, realizando uma particular ligação entre a teoria ilustrada, romântica e liberal.

Preocupações políticas e culturais, correntes entre os círculos intelectuais do país, como da "decadência" cultural de Portugal, da representatividade política e da modernização econômica foram captadas por Herculano através da atuação militar, como da sua participação no exército liberal de D.Pedro IV, panfletária e política, e por meio de reflexões baseadas num conhecimento histórico adquirido do passado nacional.

\footnotetext{
520 "A vida interior, espiritual, livre e profunda, a que levam a capacidade expansiva e o poder irradiante do Eu, concretiza-se em tudo aquilo que o indivíduo tem de singular e característico, e por tudo quanto nele, dos sentimentos aos pensamentos, é capaz de, sob a tônica do entusiasmo, manifestar espontaneamente, aflorando ao exterior, pela riqueza superabundante de conteúdos que possuem força própria, a súmula dos elementos pessoais e intransferíveis que constituem o índice de sua originalidade" NUNES, Benedito. Op.cit. p.58.

${ }^{521}$ O próprio Herculano diz isso em outras palavras. "É preciso convencê-lo de que o patriotismo, de que esse puro e sancto affecto que nos faz abandonar os commodos domesticos, as affeições do coração, $e$ arrostar com a fome, com a sêde, com a nudez, com a intemperie das estações, para irmos morrer num campo de batalha, salvando a terra em que dormem nossos maiores, defendendo a cruz do nosso adro, a vida de nossos paes, a honra de nossas irmãs e mulheres, é a manifestação mais solemne da energia do espirito humano e da abnegação christã". HERCULANO, Alexandre. "Solemnia Verba" (1850) - "A Batalha de Ourique”. In: HERCULANO, Alexandre. Opúsculos - (Tomo III) - Controvérsias e Estudos Históricos (Tomo I). $7^{\text {a }}$ edição. Portugal: Livraria Bertrand, $1^{\text {a }}$ edição de 1881, p. 109.
} 
Tanto sua atividade como jornalista, quanto a desenvolvida no campo literário e historiográfico, tiveram como objetivo principal e último aprimorar um projeto liberal de melhoria das condições culturais, intelectuais e sociais de Portugal. Não só através desse ponto de ligação político, mas também pela ambientação romântica européia, própria do século XIX, que a obra de Herculano só ganha sentido se considerada e analisada sob a luz da unidade.

Buscando determinar a marcante presença da unidade e do ecletismo das idéias e dos escritos de Herculano, o presente trabalho se propôs a analisar e interpretar a linha "filosófica" do pensamento histórico de Herculano, sob a luz de um de seus romances históricos, o Eurico, O Presbítero.

O sentido de História para Alexandre Herculano repousa numa concepção romântica, que não pode ser negada se considerarmos a sua busca incessante por captar a "índole" do povo português através de suas instituições e costumes; idealista, que se afirma na crença de um devir histórico que se engendra por meio de um nexo lógico imanente, mas dependente da ação inescrutável da Providência divina, que age na História por meio das paixões dos "grandes homens históricos"; e cientificista, representada na defesa da análise rigorosa dos documentos e pela influência direta da Escola Histórica Alemã.

Todo esse complexo campo de concepções é decorrente duma profunda formação cristã, de um vigoroso e insaciável apetite literário, que fez com que Herculano entrasse em contato com idéias que circulavam, muitas vezes sem autoria clara, nos meios intelectuais europeus, de uma militância liberal, de uma visão de mundo romântica e de uma incurável paixão pelos estudos históricos.

Cabedal intelectual que trafega, indiscriminadamente, por toda a sua rica e vigorosa obra, chamando o concentrar do fôlego interpretativo dos historiadores para até mesmo um "simples" romance histórico.

\section{Fontes e Bibliografia:}

\subsection{Fontes impressas:}

- GARRETT, Almeida. Viagens na Minha Terra. 1a edição de 1846 . Rio de Janeiro: Ediouro/Publifolha, 1997. 
- GARReTt, Almeida. O Arco de Sant’ Ana. $1^{\mathrm{a}}$ edição - volume I (1845) e volume II (1850). São Paulo: W.M. Jackson Inc., 1950.

- GARRETT, Almeida. "Da Educação" (1829). In: GARRETT, Almeida. Obras de Almeida Garrett (vol.1). Porto: Lello \& Irmãos - Editores, 1963.

- GARRET, Almeida. "Portugal na Balança da Europa" (1827). In: GARRETT, Almeida. Obras de Almeida Garrett (vol.1). Porto: Lello \& Irmãos - Editores, 1963.

- GARRETT, Almeida. "Bosquejo da História da Poesia e Língua Portuguesa" (1826). In: GARRETT, Almeida. Obras de Almeida Garrett (vol.1). Porto: Lello \& Irmãos - Editores, 1963.

- HerCulano, Alexandre. Eurico, O Presbítero. $1^{\text {a }}$ edição de 1843 no Panorama, $1^{a}$ edição em volume de 1844, São Paulo: Editora Ática, 1999.

- HerCulano, Alexandre. Eurico, O Presbítero. 1 $1^{\text {a }}$ edição de 1843 no Panorama, $1^{\mathrm{a}}$ edição em volume de 1844 , Edição crítica dirigida e prefaciada por Vitorino Nemésio. Notas e apêndices estabelecidos por Maria Helena Lucas. Glossário Arábico de David Lopes, revisto por Joaquim de Abreu Figanier. O Monasticon Tomo I, Lisboa: Livraria Bertrand, 39ª edição, s/d.

- Herculano, Alexandre. O Monge de Cister. $1^{\text {a }}$ edição de 1848. In: Alexandre Herculano. Obras Completas de Alexandre Herculano - O Monasticon (Tomo II). Portugal: Livraria Bertrand, 1977.

- HERCUlanO, Alexandre. O Bobo. Publicado na revista "Panorama” em 1843/ edição póstuma em volume de 1871. São Paulo: W.M.Jackson Inc. 1950.

- HERCULANO, Alexandre. "Historiadores Portugueses"- "Fernão Lopes" (18391840). In: Alexandre Herculano. Opúsculos - (Tomo V) - Controvérsias e Estudos Históricos (Tomo II). $5^{\text {a }}$ edição. Portugal: Livraria Bertrand, $1^{\text {a }}$ edição de 1881.

- HERCULANO, Alexandre. "Cartas sobre a História de Portugal"- Revista Universal lisbonense. $1^{\text {a }}$ edição de 1842. In: Alexandre Herculano. Opúsculos - (Tomo V) - Controvérsias e Estudos Históricos (Tomo II). $5^{\text {a }}$ edição. Portugal: Livraria Bertrand, $1^{\text {a }}$ edição de 1881 , s/d.

- HERCULANO, Alexandre. "Qual é o estado da nossa literatura? Qual é o trilho que ela hoje deve seguir?" 15/10/1834 publicado na revista Repositório Literário. In: Alexandre Herculano. Opúsculos - Tomo IX. Lisboa: Biblioteca Nacional de Lisboa, Typografia da Antiga Casa Bertrand, 1909. 
- HERCULANO, Alexandre. "Poesia (Imitação - Bello - Unidade)" publicado em 1835 na revista Repositório Literário. In: Alexandre Herculano. Opúsculos - Tomo IX. Lisboa: Biblioteca Nacional de Lisboa, Typografia da Antiga Casa Bertrand, 1909.

- HERCULANO, Alexandre. “A Velhice”. In: Panorama, no 170, 01/08/1840. Scenas de um Ano de Minha Vida e Apontamentos de Viagens. Coordenação e prefácio de Vitório Nemésio. Lisboa: Editora Bertrand, 1934. Referência obtida do livro de Maria de Fátima Marinho. O Romance Histórico em Portugal. Porto: Editora Campo das Letras, 1999.

- HERCUlANO, Alexandre. "O Pároco da Aldeia”. In: HERCULANO, Alexandre. Lendas e Narrativas. $1^{a}$ edição em volume de 1851. Rio de Janeiro: W.M.Jackson Inc. Editores, Prefácio de Eduardo Frieiro, s/d.

- HERCULANO, Alexandre. "De Jersey a Granville”. In: HERCULANO, Alexandre. Lendas e Narrativas. $1^{a}$ edição em volume de 1851. Rio de Janeiro: W.M. Jackson Inc. Editores, Prefácio de Eduardo Frieiro, s/d.

- HERCULANO, Alexandre. "Solemnia Verba 1" (1850) - "A batalha de Ourique”. In: HERCULANO, Alexandre. Opúsculos - (Tomo III) - Controvérsias e Estudos Históricos - (Tomo I). $7^{\mathrm{a}}$ edição. Lisboa: Livraria Bertrand, $1^{\mathrm{a}}$ edição de $1881, \mathrm{~s} / \mathrm{d}$.

- HERCULANO, Alexandre. "Cogitações soltas de um homem obscuro". $1^{\text {a }}$ edição de 1846. In: HERCULANO, Alexandre. Opúsculos - (Tomo VI) - Controvérsias e Estudos Históricos - (Tomo III). $5^{\text {a }}$ edição. Lisboa: Livraria Bertrand, $1^{\text {a }}$ edição de $1881, \mathrm{~s} / \mathrm{d}$.

- HERCULANO, Alexandre. "Apontamentos para a história dos bens da coroa e dos foraes". $1^{\text {a }}$ ediçãa de 1843-1844. In: HERCULANO, Alexandre. Opúsculos (Tomo VI) - Controvérsias e Estudos Históricos - (Tomo III). $5^{\text {a }}$ edição. Lisboa: Livraria Bertrand, $1^{\text {a }}$ edição de 1881 , s/d.

- HERCUlANO, Alexandre. História de Portugal - Introdução. $1^{\mathrm{a}}$ edição de 1846. Lisboa: Ulmeiro, 1980.

- HEGEL, Georg Wilhelm Friedrich. A Razão na História - Introdução à Filosofia da História Universal. $1^{a}$ edição de 1830.Lisboa: Edições 70, 1995.

- HEGEL, G.W.L. Filosofia da História. 1a edição de 1837. Tradução de Maria Rodrigues e Hans Harden. Brasília: Editora Universidade de Brasília, 2008. 
- HERDER, Johann Gottfried. Também uma filosofia da história para a formação da humanidade. $1^{a}$ edição de 1774. Tradução de José M. Justo. Lisboa: Edições Antígona, 1995.

\subsection{Bibliografia específica:}

- BAPTISTA, Jacinto. Alexandre Herculano, jornalista. Amadora [Portugal]: Livraria Bertrand, 1977.

- BEAU, Albin Eduard. Considerações sobre Alexandre Herculano e a historiografia alemã. Coimbra: Coimbra Editora, 1938.

- BEIRANTE, Cândido. Alexandre Herculano: as faces do poliedro. Lisboa: Veja, 1991.

- CARDOSO, Margarida. “Alexandre Herculano”. In: Álvaro Manuel Machado, João Soares Carvalho, José Augusto França, Margarida Cardoso, Maria de Fátima Outeirinho, Maria Isabel Pires de Lima, Maria João Simões, Ofélia Paiva Monteiro (colaboradores). História da Literatura Portuguesa (volume 4) - “O Romantismo". Portugal: Publicações Alfa, 2003.

- CARVALHO, Joaquim Barradas de. As idéias políticas e sociais de Alexandre Herculano. Lisboa: Seara Nova, 1971.

- CATROGA, Fernando. "Cap.2 - Alexandre Herculano e o Historicismo romântico". In: CATROGA, Fernando; MENDES, José Maria Amado; TORGAL, Luís Reis. História da História em Portugal (Séculos XIX - XX) - Volume I (A História através da História). Coimbra: Temas e Debates Atividades Editoriais, Lda, 1998.

- COELHO, António Borges. Alexandre Herculano. Lisboa: Editorial Presença, 1965.

- COELHO, F. Adolpho. Alexandre Herculano e o ensino público. Porto: J. A. Rodrigues, 1910.

- COELHO, Jacinto do Prado. Herculano poeta. Lisboa: Academia das Ciências de Lisboa, 1978.

- FEDELI, Maria Ivone Pereira de Miranda. O Poeta Pedagogo - Elementos de um projeto de pedagogia social na poesia de Alexandre Herculano. Dissertação de Mestrado apresentada à Faculdade de Filosofia, Letras e Ciências Humanas da Universidade de São Paulo. Departamento de Letras Clássicas e Vernáculas. Área de Literatura Portuguesa, 2002. 
- FIGUEIREDO, Fidelino de. “Cap. II - Herculano”. In: FIGUEIREDO, Fidelino de. História da Litteratura Romântica (1825 - 1870). Lisboa: Livraria Clássica Editora, 2a edição, 1923.

- MACEDO, Jorge Borges de. Alexandre Herculano - Polémica e Mensagem. Prêmio de Ensino Alexandre Herculano 1977/78. Portugal: Livraria Bertrand, 1980.

- MARINHO, Maria de Fátima. O romance histórico de Alexandre Herculano. Porto: Faculdade de Letras, 1992.

- NEMÉSIO, Vitorino. A Mocidade de Herculano até a volta do exílio (18101832). Lisboa: Livraria Bertrand, Volume II, 1934.

- MARTINS, J. P. de Oliveira. Alexandre Herculano. Lisboa: Livros Horizonte, 1970.

- OLIVEIRA, Paulo Motta. “Alexandre Herculano: malhas da história, armadilhas da ficção". In: Maria Cecília Bruzzi Boechat, Paulo Motta Oliveira, Silvana Maria Pessôa de Oliveira. (Orgs.). Romance Histórico (Recorrências e Transformações). Belo Horizonte: FALE/UFMG, Centro de Estudos Portugueses, 2000.

- OLIVEIRA, Silvana Maria Pessôa de. "Alexandre Herculano, narrador". In: Maria Cecília Bruzzi Boechat; Paulo Motta Oliveira; Silvana Maria Pessôa de Oliveira. (Orgs.). Romance Histórico (Recorrências e Transformações). Belo Horizonte: FALE/UFMG, Centro de Estudos Portugueses, 2000.

- PEREIRA, B. Capelo. "Verbete: Herculano". In: BUESCU, Helena Carvalhão (Coord.). Dicionário do Romantismo Literário Português. Lisboa: Editorial Caminho, S.A., 1997.

- PIMENTEL, António de Serpa. Alexandre Herculano e o seu tempo: estudo crítico. Lisboa: Imprensa Nacional, 1881.

- REIS, Carlos. "Herculano e a ficção romântica". In: A construção da leitura. Ensaios de metodologia e crítica literária. Coimbra: INIC, 1982.

- RIBEIRO, Carlos Portugal. Alexandre Herculano - a sua vida e a sua obra (1810-1877). Lisboa: Tip. da Empresa Nacional de Publicidade, 1933.

- SARAIVA, António José. Herculano desconhecido (1851-1853). Amsterdã: Publicações Europa América, 1971.

- SARAIVA, António José. Herculano e o Liberalismo em Portugal. Lisboa: Livraria Bertrand, 1977.

- SERRÃO, Joaquim Veríssimo. Herculano e a Consciência do Liberalismo Português. Lisboa: Livraria Bertrand, 1977. 
- SILVA, Maria Beatriz Nizza da. Alexandre Herculano - O Historiador. Rio de Janeiro: Livraria Agir Editôra, Coleção “Nossos Clássicos”, 1964.

- TRINDADE, Manuel. O Padre em Herculano. Lisboa: Editorial Verbo, 1965.

\subsection{Bibliografia Geral:}

- BARRENTO, João (Org.). Literatura alemã: textos e contextos (1700-1900). Lisboa: Editorial Presença, 2 vol., 1989.

- BERBEL, Márcia. Deputados do Brasil nas Cortes Portuguesas de 1821-1822: Um Estudo sobre o Conceito de Nação. Tese apresentada ao Departamento de História da Faculdade de Filosofia, Letras e Ciências Humanas da Universidade de São Paulo, como parte dos requisitos para a obtenção do título de doutor na área de História Econômica, 1997.

- BERLIN, Isaiah. "Cap.6: A revolução romântica: uma crise na história do pensamento moderno". In: $O$ sentido de realidade (estudos das idéias e de sua história). Rio de Janeiro: Editora Civilização Brasileira, 1999.

- BERLIN, Isaiah. Vico e Herder. Brasília: Editora da Universidade de Brasília, 1982.

- BERMANN, Antoine. A prova do estrangeiro: A cultura e tradução na Alemanha romântica: Herder, Goethe, Schlegel, Novalis, Humboldt, Scheiermacher, Holderlin. Tradução de Maria Emília Pereira Chanut. Bauru, São Paulo: Edusc, 2002.

- BOECHAT, Maria Cecília Bruzzi; OlIVEIRA, Paulo Motta; OLIVEIRA, Silvana Maria Pessoa de. (Orgs.). Romance Histórico (Recorrências e Transformações). Belo Horizonte: FALE/UFMG, Centro de Estudos Portugueses, 2000.

- BONIFÁCIO, Maria de Fátima. Seis Estudos sobre o Liberalismo Português. Lisboa: Editorial Estampa, 1991.

- BORNHEIM, Gerd. "Filosofia do Romantismo". In: GUINSBURG, J. (Org.). O Romantismo. São Paulo: Editora Perspectiva, 1978.

- BOSCH, Bruno. História da Literatura alemã. São Paulo: Edusp, 1967. 
- BRAGA, Teófilo. História do Romantismo em Portugal. Lisboa: Colecção Ulmeiro/ Universidade, nº 6, (fac-símile da edição de 1880), Dezembro de 1984.

- BUESCU, Helena Carvalhão (Coord.). Dicionário do Romantismo Literário Português. Lisboa: Editorial Caminho, S.A., 1997.

- CABRAL, Manuel Villaverde. O desenvolvimento do Capitalismo em Portugal no século XIX. Lisboa: Regra do Jogo Editores, 1981.

- CARVALHO, Joaquim Barradas de. Da História-Crónica à História-Ciência. Lisboa: Livros Horizonte, 1976.

- CASSIRER, Ernst. A questão Jean-Jacques Rousseau. Prefácio e posfácio de Peter Gay. São Paulo: Editora Unesp, 1999.

- CASSIRER, Ernst. "VII - Os Problemas Fundamentais da Estética”. A Filosofia do Iluminismo. São Paulo: Ed. da Universidade Estadual de Campinas, 1994.

- CIDADE, Hernani. Lições de Cultura e Literatura Portuguesas - $\mathbf{2}^{\circ}$ volume. Coimbra: Coimbra Editora Limitada, 7ª edição, 1984.

- CHAUNU, Pierre. A civilização na Europa das luzes. Lisboa: Estampa, 1985.

- CHAVES, Castelo Branco. O romance histórico em Portugal. Portugal: Livraria Bertrand, Biblioteca Breve (Instituto de Cultura Portuguesa), 1979.

- COURTINE, Jean-François. A Tragédia e o Tempo da História. Tradução de Heloisa B.S.Rocha. São Paulo: Editora 34, 2006.

- CUNHA, D. Luís da. Instruções Políticas. Lisboa: Comissão Nacional para as Comemorações dos Descobrimentos Portugueses, 2001.

- DIAS, J. S. da Silva. "A revolução liberal portuguesa: amálgama e não substituição de classes”. In: PEREIRA, Miriam Halpern; FERREIRA, Maria de Fátima Sá e Melo \& SERRA, João B. (Coordenação). O Liberalismo na Península Ibérica na primeira metade do século XIX. Comunicações ao Colóquio organizado pelo Centro de Estudos de História Contemporânea Portuguesa, $1^{\circ}$ volume, Portugal: Sá da Costa Editora, 1981.

- FALCON, Francisco José Calazans. Iluminismo. São Paulo: Ática, 1986.

- FALCON, Francisco José Calazans. A Época Pombalina. São Paulo: Ática, Coleção Ensaios, 1993.

- FALCON, Francisco José Calazans. "Historicismo: Antigas e Novas Questões". In: História Revista (Revista do Departamento de História e do Programa de Mestrado em História). Goiânia, 7(1/2), jan./dez. 2002, p.23 - 54. 
-FALBEL, Nachman. "Fundamentos Históricos do Romantismo". In: GUINSBURG, J.(Org.). O Romantismo. São Paulo: Editora Perspectiva, 1978.

- FERREIRA, Alberto. Perspectiva do Romantismo português (1833-65).

Lisboa: Moraes Editores, 1979.

- FRANÇA, José-Augusto. História do Romantismo em Portugal. Lisboa:

Livros Horizonte, 6 volumes, 1974.

- FURET, François (Org.). O homem romântico. Trad. Miguel Serras Pereira. Lisboa: Editorial Presença, 1999.

- GARDINER, Patrick. Teorias da História. Lisboa: Fundação Calouste Gulbenkian, 1968.

- GOETHE, Johann Wolfgang Von. Os Anos de aprendizado de Wilhelm Meister. Tradução de Nicolino Simone Neto/Apresentação de Marcus Vinicius Mazzari. São Paulo: Editora 34, 2006.

- GOFF, Jacques Le. A História Nova. São Paulo: Martins Fontes,2005.

- GRESPAN, Jorge. "Hegel e o Historicismo". In: História Revista (Revista do Departamento de História e do Programa de Mestrado em História). Goiânia, 7(1/2), jan./dez. 2002, p.55- 78 .

- GRESPAN, Jorge. Revolução Francesa e Iluminismo. São Paulo: Editora Contexto, 2003.

- GUSDORF, Georges. Le Romantisme. Paris: Payot, 1993, 3 volumes.

- HAMPSON, Norman. O Iluminismo. Lisboa: Ulisséia, 1973.

- HARTMANN, Nicolai. A Filosofia do Idealismo Alemão. Lisboa: Fundação Calouste Gulbelkian, 1983.

- HARTMAN, Robert S. "Introdução - O Significado de Hegel para a História”. In: HEGEL, Georg Wilhelm Friedrich. A Razão na História (Uma Introdução Geral à Filosofia da História). São Paulo: Editora Moraes, Tradução de Beatriz Sidou, Introdução de Robert S. Hartman, 1990.

- HAUSER, Arnold. História da Arte e da Literatura. São Paulo: Martins Fontes, 1995.

- HAZARD, Paul. O pensamento europeu no século XVIII. São Paulo: Martins Fontes, 1974.

- HOBSBAWM, Erich. A Era das Revoluções (1789-1848). Rio de Janeiro: Editora Paz e Terra, 1982.

- IM HOF, Ulrich. A Europa no século das luzes. Lisboa: Presença, 1995. 
- INWOOD, Michael. Dicionário Hegel. Rio de Janeiro: Jorge Zahar Ed., 1997.

- JÚNIOR, José Luiz Foureaux de Souza. "O narrador, a literatura e a História: questões críticas". In: Maria Cecília Bruzzi Boechat; Paulo Motta Oliveira; Silvana Maria Pessôa de Oliveira. (Orgs.). Romance Histórico (Recorrências e Transformações). Belo Horizonte: FALE/UFMG, Centro de Estudos Portugueses, 2000 .

- KOSELLECK, Reinhart. Crítica e crise - Uma contribuição à patogênese do mundo burguês. Rio de Janeiro: EDUERJ: Contraponto,1999.

- LOBO, Luiza (Org.). Teorias poéticas do romantismo. Rio de Janeiro/Porto Alegre: Editora da UFRJ/ Porto Alegre: Mercado Aberto, 1987.

- LOURENÇO, Eduardo. Mitologia da saudade: seguido de Portugal como destino. São Paulo: Companhia das Letras, 1999.

- LOWY, Michael \& SAYRE, Robert. Revolta e Melancolia - O romantismo na contramão da modernidade. Petrópolis, Rio de Janeiro: Editora Vozes, 1995.

- LUKÁCS, Georg. A Teoria do Romance. Tradução, posfácio e notas de José Marcos Mariani de Macedo. São Paulo: Duas Cidades; Editora 34, 2000.

- LYRA, Maria de Lourdes Viana. A utopia do poderoso Império (Portugal e Brasil: bastidores da política 1798-1822). Rio de Janeiro: Sette Letras, 1994.

- MACHADO, Álvaro Manuel. As origens do Romantismo em Portugal. Lisboa: Livraria Bertrand, Biblioteca Breve, vol.36, 1979.

- MACHADO, José Pedro. Dicionário Etimológico da Língua Portuguesa (Com a mais antiga documentação escrita e conhecida de muitos dos vocabulários estudados) - Quinto Volume (Q-Z). Lisboa: Livros Horizonte, 6ª edição, 1990.

- MARCUSE, Herbert. Razão e Revolução - Hegel e o advento da teoria social. São Paulo: Editora Paz e Terra S/A, 2004.

- MARINHO, Maria de Fátima. O romance histórico em Portugal. Porto: Ed. Campo das Letras, 1999.

- MARTINS, Oliveira. História de Portugal. 1a edição de 1879. Obras completas de Oliveira Martins. Lisboa: Guimarães Editores, 1942.

- MARTINS, Oliveira. Portugal Contemporâneo - volumes 1 e 2. Lisboa: Guimarães Editores, 1996.

- MEINECKE, Friedrich. El Historicismo y su Gênesis. Versión española de José Mingarro, San Martin y Tomás Muñoz Molina. México: Fondo de Cultura Econômica, 1943. 
- MIRANDA, José Américo. "Romance e História”. In: Maria Cecília Bruzzi Boechat; Paulo Motta Oliveira; Silvana Maria Pessôa de Oliveira (Orgs.). Romance Histórico em Portugal (Recorrências e Transformações). Belo Horizonte: FALE/UFMG, Centro de Estudos Portugueses, 2000.

- MOISÉS, Massaud (org.). A Literatura Portuguesa em Perspectiva - volume III - Romantismo/Realismo. São Paulo: Editora Atlas S.A., 1994.

- MOISÉS, Massaud. Dicionário de Termos Literários. São Paulo: Editora Cultrix, $12^{\mathrm{a}}$ edição, 2004.

- MONTEIRO, Ofélia Milheiro Caldas Paiva. A Formação de Almeida Garrett. Coimbra, 2 volumes, 1971.

- MORETTI, Franco. Atlas do Romance Europeu (1800-1900). São Paulo: Boitempo, 2003.

- NASCIMENTO, Maria das Graças de Souza. Ilustração e história: o pensamento sobre história no Iluminismo francês. São Paulo: Discurso, 2001.

- NEMI, Ana Lúcia Lana (Org.) e RUIZ, Rafael (Org.). Sonho e Razão no Mundo Ibérico. Rio de Janeiro: Tempo Brasileiro, 2008.

- NEVES, Lúcia Maria Bastos Pereira; OLIVEIRA, Paulo Motta; DAVID, Sérgio Nazar; FERREIRA, Tânia Maria Tavares Bessone da Cruz. (Orgs.). Literatura e política em Portugal (1820-1856). Rio de Janeiro: Ed.UERJ, 2007.

- NOVAIS, Fernando A. Portugal e Brasil na Crise do Antigo Sistema Colonial (1777-1808). São Paulo: Editora Hucitec, 2001.

- NUNES, Benedito. "A Visão romântica". In: GUINSBURG, J.(Org.). O Romantismo. São Paulo, Editora Perspectiva, 1978.

- PRAZ, Mario. A carne, a morte e o diabo na Literatura Romântica. Campinas: Editora da Unicamp, 1996.

- REIS, Carlos (Direção). História crítica da Literatura Portuguesa. Lisboa: Editora Verbo, s/d.

- REISEWITZ, Marianne. Dom Fernando José de Portugal e Castro: Prática Ilustrada na Colônia (1788-1801). Dissertação de Mestrado: FFLCH-USP, 2001.

- ROLAND, Desne. Os materialistas franceses. Lisboa: Seara Nova, 1969.

- ROSENFELD, Anatol. Texto e Contexto. São Paulo: Editora Perspectiva, 1973.

- ROUSSEAU, Jean-Jacques. Júlia ou A Nova Heloísa. Tradução de Fúlvia M.L.Moretto. São Paulo - Campinas, Hucitec/Editora da UNICAMP, 1994. 
- ROUSSEAU, Jean-Jacques. Os devaneios do Caminhante Solitário. Tradução e introdução de Fúlvia M.L.Moretto. Brasília: Editora UnB, 1995.

- SÁ, Victor de. Instauração do Liberalismo em Portugal. Portugal: Livros Horizonte, 1987.

- SALIBA, Elias Thomé. As utopias românticas. São Paulo: Editora Liberdade, 2003.

- SANTOS, Fernando Piteira. Geografia e Economia da Revolução de 1820. Lisboa: Publicações Europa-América, s/d.

- SANTOS, Luis Alberto Brandão. "Literatura e História: convergências de possíveis”. In: Maria Cecília Bruzzi Boechat; Paulo Motta Oliveira; Silvana Maria Pessôa de Oliveira. (Orgs.). Romance Histórico (Recorrências e Transformações). Belo Horizonte: FALE/UFMG, Centro de Estudos Portugueses, 2000.

- SARAIVA, António José \& LOPES, Óscar. História da Literatura Portuguesa. Portugal: Porto Editora, 1975.

- SARAIVA, José Hermano. História Concisa de Portugal. Portugal: Publicações Europa-América, 1999.

- SERRÃO, João. Liberalismo, Socialismo, Republicanismo (antologia de pensamento político português). Selecção, introdução e notas de João Serrão. Lisboa: Livros Horizonte, 1979.

- SERRÃO, Joel. Do Sebastianismo ao Socialismo em Portugal. Lisboa: Livros Horizonte Lda, 1973.

- SERRÃO, Joel. e OLIVEIRA, A.H. (Direcção). Nova História de Portugal Portugal e a Instauração do Liberalismo (volume IX). Lisboa: Editora Presença, 2002.

- SHELLING, F.W.J. Filosofia da Arte. São Paulo: Edusp, 2001.

- SILVA, Ana Rosa Cloclet da. Inventando a Nação - Intelectuais Ilustrados e Estadistas Luso-Brasileiros na Crise do Antigo Regime Português (1750-1822). São Paulo: Editora Hucitec/Fapesp, 2006.

- SILVA, Antonio de Moraes. Diccionario da Língua Portuguesa (Tomo II - FZ), Lisboa: Typographia de Antonio José da Rocha, Rua da Vinha, no 38 (Ao Bairro Alto, $6^{\text {a }}$ edição, 1858.

- SIMÕES, João Gaspar. Perspectiva histórica da ficção portuguesa (das origens ao século XX). Lisboa: Dom Quixote, 1987. 
- STAROBISNSKI, Jean. 1789: Os emblemas da razão. São Paulo: Companhia das Letras, 1988.

- STAROBISNKI, Jean. Jean-Jacques Rousseau: A Transparência e o Obstáculo/ Sete ensaios sobre Rousseau. São Paulo: Companhia das Letras,1991.

- TALMON, J. Romantismo e revolta (1815-1848): Lisboa: Verbo, 1967.

- VASCONCELOS, Sandra Guardini. A Formação do Romance Inglês. São Paulo: Editora Hucite/Fapesp, 2007.

- VECHI, Carlos Alberto. “A estética romântica”. In: MOISÉS, Massaud. (Org.). A Literatura Portuguesa em Perspectiva. Vol.III. São Paulo: Editora Atlas S.A., 1994.

- VICO, G. Princípios de uma ciência nova. São Paulo: Abril, 1979.

- VOLOBUEF, Karin. Frestas e Aresta - A Prosa de Ficção do Romantismo na Alemanha e no Brasil. São Paulo: Fundação Editora da UNESP (FEU), 1999.

- WEHLING, A. A invenção da história: estudos sobre o historicismo. Niterói: Ed. UFF, 1994.

- WELLEK, René. História da Crítica Moderna (volume I - Século XVIII). Editora Herder, 1967.

- WERLE, Marco Aurélio. “Jornal de Resenhas”. Folha de São Paulo, Sábado, 14 de junho de 2003.

- WERLE, Marco Aurélio. “Winckelmann, Lessing e Herder: Estética do Efeito?”. In: Revista Trans/Form/Ação, São Paulo, 23: 19-50, UNESP, Marília - SP, 2000.

-WERLE, Marco Aurélio. A poesia na estética de Hegel. São Paulo: Associação Editorial Humanitas: Fapesp, 2005.

- WHITE, Hayden. Meta-História: A Imaginação Histórica do Século XIX. São Paulo: Edusp, 1995. 


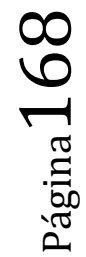

Página |168 